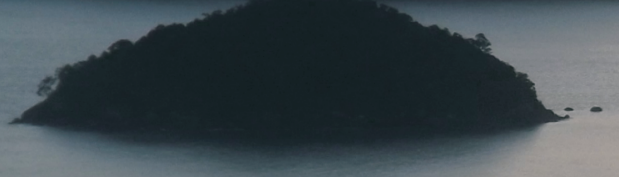

A Diáspora Africana no litoral Norte paulista: desafios e possibilidades de uma abordagem arqueológica.

Luciana Bozzo Alves
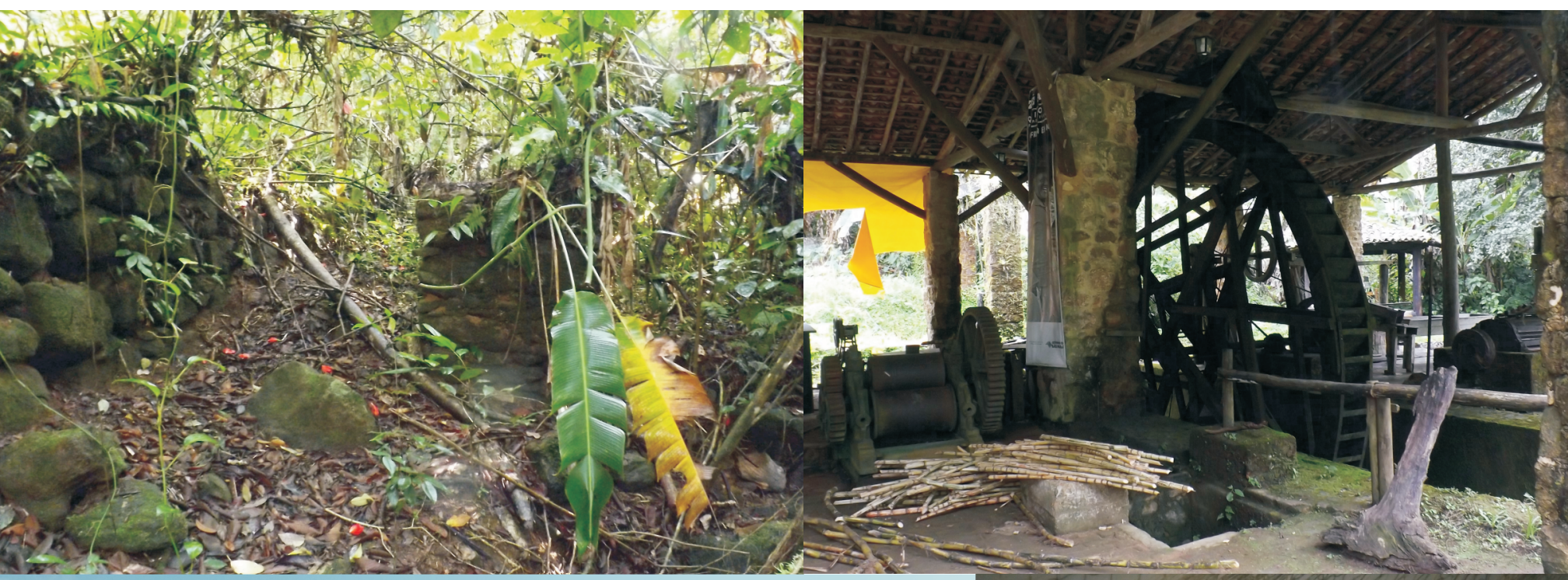


\author{
UNIVERSIDADE DE SÃO PAULO \\ MUSEU DE ARQUEOLOGIA E ETNOLOGIA \\ PROGRAMA DE PÓS-GRADUAÇÃO EM ARQUEOLOGIA
}

\title{
A Diáspora Africana no litoral Norte paulista: desafios e possibilidades de uma abordagem arqueológica.
}

Luciana Bozzo Alves

Área de Concentração: Arqueologia

Orientador: Prof. Dr. Pedro Paulo de Abreu Funari

Linha de Pesquisa 3 - Arqueologia e Sociedade

São Paulo, 2016 


\author{
UNIVERSIDADE DE SÃO PAULO \\ MUSEU DE ARQUEOLOGIA E ETNOLOGIA \\ PROGRAMA DE PÓS-GRADUAÇÃO EM ARQUEOLOGIA
}

\title{
A Diáspora Africana no litoral Norte paulista: desafios e possibilidade de uma abordagem arqueológica.
}

\section{Luciana Bozzo Alves}

Dissertação apresentada ao Programa de Pós-Graduação em Arqueologia, do Museu de Arqueologia e Etnologia da Universidade de São Paulo, para obtenção do título de Mestre em Arqueologia.

Orientador: Prof. Dr. Pedro Paulo de Abreu Funari

Versão revisada,

A versão original encontra-se na biblioteca do MAE.

São Paulo, 2016. 
Dedicatória

Aos meus pais, João e Lúcla, pelo exemplo de amor, humildade, respeito e fé. A mınhas ırmãs Lella e Lilıan e a meu sobrınho João Gabrıel, por fazerem a mınha vida mais feliz.

Ao Paulo, por compartilhar comigo seu olhar sobre Ubatuba e pelo acolhımento, diálogos e valıosos ensınamentos durante os últımos anos.

À Camila, sua dedicação e talento como pesquisadora são exemplos para mım e serviram de inspıração para esse trabalho. 


\section{Agradecimentos}

Ogunhê, Paracorí Ogum! Eparrei Oyá! Epa Babá Oxaguiã! Saravá todos os orixás!!! Salve a Umbanda!

A meus pais que, apesar da distância nunca deixaram de apoiar todas as minhas escolhas. Quero que saibam que, sem suas orações e sem o amor de vocês, com certeza eu não teria chegado até aqui. Obrigada meu pai por continuar na sua luta pela vida e por acreditar que nosso amor pode modificar sua condição. Obrigada minha mãe, por iluminar as nossas vidas e por sempre ter me dito as palavras certas em todos os momentos da minha caminhada. Agradeço a meu sobrinho João Gabriel e minha irmã Lílian que mesmo distantes, colaboraram da maneira que puderam para que o "sonho pudesse ser buscado".

Quero agradecer ao professor Dr. Pedro Paulo Funari por ter aceitado orientar esse trabalho. Seu olhar sempre objetivo e certeiro, fez das conversas vivenciadas momentos de extremo aprendizado.

Agradeço aos docentes do MAE/USP, em especial à Profa. Drª Marisa Coutinho, ao Prof. Dr. Paulo De Blasis e à Profa. Drạ. Maria Beatriz Borba Florenzano, além do Prof. Dr. Eduardo Góes Neves que ministrou a primeira disciplina que cursei no MAE, ainda na graduação. Agradeço também à Prof. ${ }^{\text {a }}$ Dra. Maria Helena P. T. Machado, da Faculdade de Filosofia, Letras e Ciências Humanas e à Prof. ${ }^{a}$ Dra. Beatriz Gallotti Mamigonian, que ministraram a disciplina "Cidadania de Africanos e Afrodescendentes no Brasil e no Atlântico" na FFLCH.

Ao prof. Dr. Camilo Vasconcelos e ao prof. Dr. Paulo Eduardo Zanettini agradeço pelas enriquecedoras sugestões durante o exame de qualificação.

Agradeço também aos colegas do MAE, em especial Laura Brandão, Thatiana Racy, Juliana Freitas e Renan Pezzi. Agradeço também ao pessoal da secretaria que sempre me atendeu gentilmente, em especial a Aline, Karen e à Regina Leopoldo e Silva.

Sandra Nami, obrigada por disponibilizar as informações sobre Ubatuba.

Agradeço ao professor Jaime Rodrigues da UNIFESP, que prontamente respondeu meus questionamentos.

À Cleide Azevedo (ITESP-Ubatuba), agradeço por gentilmente ter me recebido e colaborado para meu entendimento sobre os complexos processos envolvidos no reconhecimento das comunidades quilombolas.

Agradeço ao Itamar, que me acompanhou durante grande parte das prospecções as praias e comunidades caiçaras em Ubatuba.

Meus sinceros agradecimentos aos colabores que, durante as etapas de campo compartilharam comigo um pouco de suas vivências: Benedita Conceição, Itamar Marcelino de Souza, Benedito da Conceição (seu Dico - Praia do Almada); Benedito Correia da Silva (Pu) e Elias Lopes de Oliveira (Praia de Piçinguaba); Celso Carmo Firmino Soares e Eliezer Soares (Praia do Camburi); Irmandino de Souza (seu Mandico - Praia Brava de Almada) e José Vieira (seu Zé Pedro - Quilombo da Fazenda Picinguaba); Fernando de Souza Rangel (Formiga - Praia dos Castelhanos). 
As amigas e eternas "professoras" Maria Fernanda Palanch-Hans, Cintia Miyaji, Mariângela Oliveira de Barros e Carolina Bertozzi, por terem me ajudado tanto durante a graduação. Agradeço ainda a MF, que me ajudou a esboçar o projeto desse mestrado ainda em 2008.

Daniela Dionizio obrigada pela troca de ideias e sugestões de leituras. Agradeço a você e ao Rodrigo por cuidarem dos meus gatos durante minhas ausências.

Agradeço à querida amiga Glória Tega, que sempre com alegria e boa vontade tem realizado a revisão dos textos. Sem sua colaboração com certeza só nesse trabalho, estariam faltando umas 287 vírgulas e algumas dezenas de crases.... rs. Muito obrigada querida, por tudo! Agradeço, ainda, ao Flávio Calippo, que tem me acompanhado desde a graduação. Obrigada por seu apoio e por ter sempre acreditado em mim. Não poderia deixar de agradecer a dona Dirce (in memorian): obrigada por ter feito seu Buda me achar.

Também agradeço a todos aqueles que partilharam e partilham comigo a convivência profissional na Zanettini Arqueologia, em especial a Matilde Barros e ao Lucas Troncoso.

À Gabriela Faria, agradeço por, com capricho e zelo, produzir o material gráfico aqui apresentado. Agradeço também ao Leandro pelo empenho na formatação das imagens.

Ao meu primo Marcel, que esteve presente ao longo de toda essa jornada e que me ajudou a manter a sanidade nos momentos finais da escrita desse trabalho. Dudu, sem seu carinho e sem as rosas brancas o final dessa jornada teria sido mais dolorido.

Um grande presente ao longo dessa caminhada foi ter descoberto o meu "meio-irmão" Odair Assunção. Agradeço a você por todas as indicações de leituras e pela insanidade nos momentos certos. Agradeço também a Márcia Padilha, que com seu riso fácil tornou essa caminhada mais leve.

A minha querida amiga Guiomar. Neguinha, seu apoio durante essa jornada foi imprescindível para que eu chegasse até aqui. Sem sua boa vontade e orações o caminho teria sido difícil e os obstáculos praticamente intransponíveis.

Agradeço aos amigos que tanta falta me fazem e, que envolvida na escrita desse trabalho, quase não pude ver: Fabiana Oliveira, Tânia Moraes, Rafael Valadão, Val Pires, Élcio Rodrigues, Helena Ritto, Fábio Torres, Anabel Andrés, Sueli Bezerril, Lígia Freitas e Vera Achatkin. Além das queridas oceanógrafas Aline Barbosa, Juliana Capellari, Marina Souza e Juliana Kayano. Agradeço ainda a Aline pela deliciosa tarde em Bertioga juntamente a Cleide e ao Barbosa.

Ao Paulo Zanettini, por ser uma pessoa muito importante na minha formação, pessoal e profissional. Nosso convívio, praticamente cotidiano nos últimos oito anos tem se revelado extremamente enriquecedor. Agradeço pelas palavras certas, nas horas certas, as quais me diluíram fantasmas e medos, abrindo os campos da visão e que possibilitaram e possibilitam acima de tudo, ousar.

À Vera Achatkin, agradeço por ter me incentivado muito a voltar a estudar e por financiar boa parte da minha graduação. Sem sua amizade e seu apoio nada disso seria possível. Espero ainda poder fazer por alguém tudo aquilo que você fez por mim e não deixar essa "corrente do bem" se quebrar. 
Á Camila, agradeço imensamente por ter me ajudado durante essa jornada. Pelas sugestões de bibliografias, pelo incentivo e pelas provocações que me obrigaram a sair da minha zona de conforto. Agradeço pela abertura de horizontes e por ensinar-me a duvidar das certezas. Sem dúvida sua colaboração ao longo da minha vida pessoal, profissional e acadêmica tem sido fundamental para a minha formação. Obrigada pela amizade incondicional, pelas conversas, pelo franguinho e pela Eisenbahn.

E, por fim, agradeço a minha irmã Leila. Sem seu apoio e colaboração durante todo o desenvolvimento dessa pesquisa, com certeza absoluta, ela não teria sido possível. Obrigada por cuidar de mim e de nossa família que mia... e que foram companhia constante durante a produção dessa dissertação. Nesse sentido, agradeço muito à presença da Neca, do Zulú, da Vaca, da Zebra, da Foca e da Franga e, claro, a presença espiritual do Muphasa. Por isso, a você dedico a coautoria desse trabalho. 
Yá Yá Massemba

Compositor: Roberto Mendes/Capınam Intérprete: Marıa Bethânıa

Que noite mais funda calunga No porão de um navio negreıro Que viagem mais longa candonga

Ouvindo o batuque das ondas Compasso de um coração de pássaro No fundo do catıveıro É o semba do mundo calunga Batendo samba em meu peito Kawo Kabiecile Kawo Okê arô oke

Quem me pariu fol o ventre de um navio

Quem me ouviu fol o vento no vazio

Do ventre escuro de um porão

Vou baixar no seu terreiro

Eparaıo, machado, trovão Epa justıça de guerreıro

É semba ê ê samba á é o céu que cobriu nas noites de frio mınha solıdão Ê semba ê ê samba á é oceano sem, fım sem amor, sem ırmão ê kaô quero ser seu tambor

Ê semba ê ê samba á eu faço a lua brilhar o esplendor e clarão luar de luanda em meu coração

umbigo da cor abrigo da dor a primeıra umbigada massemba yáyá massemba é o samba que dá

Vou aprender a ler Pra ensinar meus camaradas!

Vou aprender a ler Pra ensinar meus camaradas! 


\section{RESUMO}

A presente pesquisa buscou compreender os processos históricos relacionados à diáspora africana no litoral Norte paulista a partir de uma perspectiva arqueológica. Com a proibição do comércio negreiro em meados do século XIX, o litoral Norte paulista, tão próximo do Vale do Paraíba onde a cultura cafeeira estava em expansão, foi palco de inúmeros desembarques clandestinos realizados nas praias da região. Por meio da integração de fontes diversificadas, como evidências materiais, indicadores da paisagem, narrativas orais, fontes secundárias e com especial atenção à Historiografia sobre o tema, foi possível traçar possibilidades interpretativas acerca da diáspora africana na região estudada. Destarte, tais levantamentos possibilitaram atribuir ao litoral Norte paulista um alto potencial para o estudo de sítios e vestígios arqueológicos associados à temática, seja em ambiente continental ou insular, em compartimentos emersos ou submersos.

Palavras-Chave: Arqueologia da Diáspora Africana, Tráfico negreiro, Litoral Norte Paulista. 


\begin{abstract}
This research aimed at understanding the historic processes regarding the African Diaspora in the north coast of São Paulo from an archaeological perspective. With the prohibition of slave trading in the mid-nineteenth century, the north coast of São Paulo was the scene of countless clandestine landings on the beaches of the region, once it was very close to the Paraíba Valley, where coffee cultivation was expanding. Through the integration of diverse sources such as material hard evidence, landscape indicators, spoken narratives, secondary sources and a particular focus on Historiography, it was possible to draw interpretative possibilities about the African diaspora in the region under study. Therefore, these surveys have made possible for the north coast region of São Paulo to be assigned as a high potential study place of archaeological sites and remains related to the theme, both in the mainland and on the island environment, either as surfaced or immersed compartments.
\end{abstract}

Keywords: Archeology of the African Diaspora, Slave Trading, North Coast of São Paulo 


\section{Lista de Abreviaturas e Siglas}

CONDEPHAAT - Conselho de Defesa do Patrimônio Histórico, Arqueológico, Artístico e Turístico.

FCP - Fundação Cultura Palmares

FUNDACC - Fundação Educacional e Cultural de Caraguatatuba

FUNDACI - Fundação Cultural de Ilhabela

INCRA - Instituto Nacional de Colonização e Reforma Agrária

INRC - Inventário Nacional de Referências Culturais

IPHAN - Instituto do Patrimônio Histórico e Artístico Nacional

ITESP - Instituto de Terras do Estado de São Paulo.

MACC - Museu de Arte e Cultura de Caraguatatuba

MAE - Museu de Arqueologia e Etnologia

NOAA - National Oceanic and Atmospheric Administration

PESM - Parque Estadual Serra do Mar

RTC - Relatório Técnico Científico

RTID - Relatório Técnico de Identificação e Delimitação

SUDELPA - Superintendência de Desenvolvimento do Litoral Paulista.

UNESCO - Organização das Nações Unidas para a Educação, a Ciência e a Cultura USP - Universidade de São Paulo 


\section{ÍNDICE}

INTRODUÇÃO. .7

Capítulo 1. Arqueologia da Diáspora, uma forma de olhar.................................12

1.1. Arqueologia: buscando conceituar ...............................................................13

1.2. Arqueologia Histórica: procurando descolonizar .............................................16

1.3. Arqueologia da Diáspora: uma forma de olhar............................................20

1.3.1. A contribuição da Arqueologia Subaquática ................................................23

Capítulo 2. Diáspora Africana, Tráfico Negreiro e Escravidão adentram ao terreno da Arqueologia Brasileira.....................................................................36

2.1. As pesquisas sobre a Arqueologia da Diáspora no Brasil.................................38

2.2.De uma Arqueologia dos Quilombos a uma Arqueologia com as Comunidades

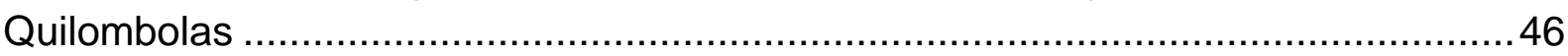

2.2.1. A Arqueologia e a Etnoarqueologia em Comunidades Quilombolas ..............50

Capítulo 3. 0 palco da pesquisa: o Litoral Norte Paulista. .54

3.1.Primeiras aproximações: características ambientais, aspectos socioeconômicos e

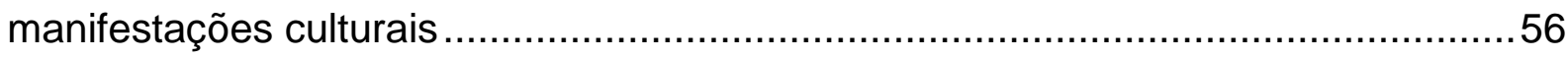

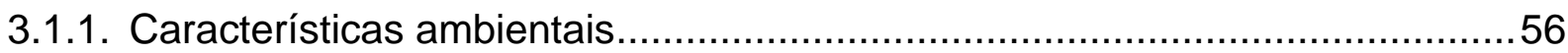

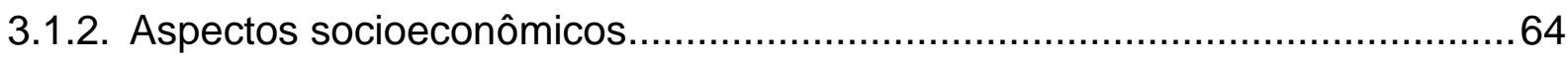

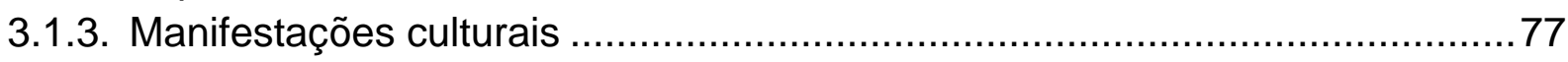

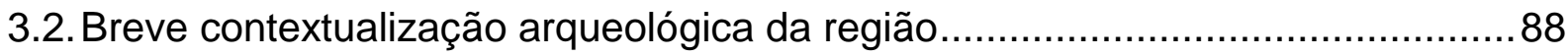

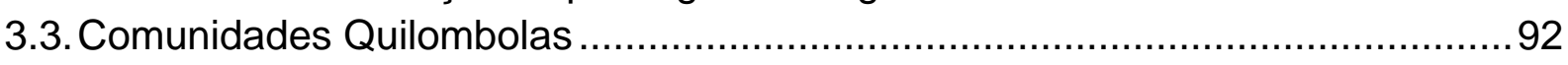

3.3.1. Comunidade do Quilombo Camburi.............................................................97

3.3.2. Comunidade do Quilombo da Fazenda Picinguaba....................................103

3.3.3. Comunidade do Quilombo Sertão do Itamambuca....................................111

3.3.4. Comunidade do Quilombo Caçandoca ...................................................116

Capítulo 4. Paisagens da Diáspora Africana: acerca da (in)visibilidade dos locais

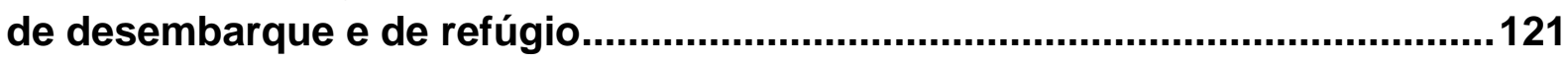

4.1. Olhar a partir dos documentos históricos ...................................................123

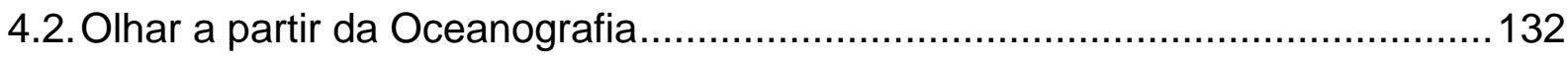

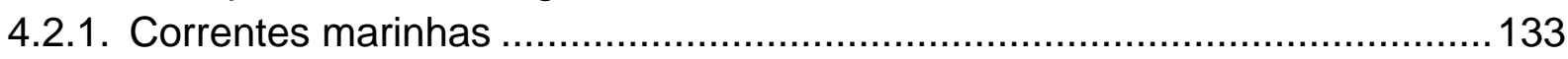

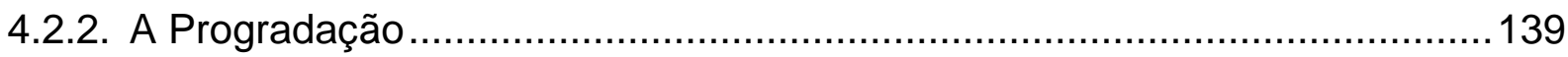

4.3. Olhar a partir da Arqueologia: algumas possibilidades ................................. 143

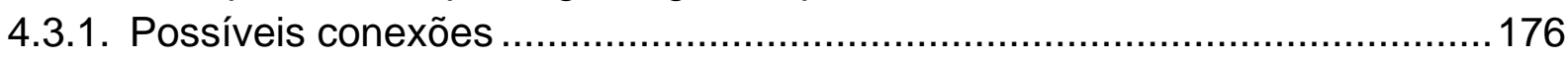

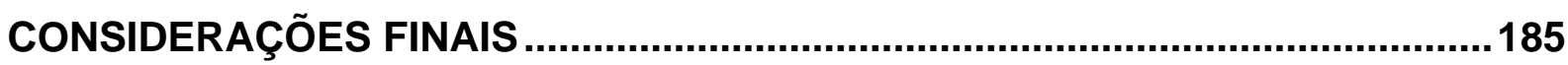

Referências Bibliográficas ......................................................................190 


\section{LISTA DE ANEXOS}

Anexo 1. Locais indicados como possíveis pontos de desembarques - Fontes consultadas 


\section{LISTA DE PRANCHAS}

Prancha 1. Pesquisas arqueológicas em sítios de naufrágios de navios negreiros

Prancha 2. Quilombo do Camburi

Prancha 3. Quilombo do Camburi

Prancha 4. Quilombo da Fazenda Picinguaba

Prancha 5. Quilombo da Fazenda Picinguaba

Prancha 6. Quilombo Sertão do Itamambuca

Prancha 7. Quilombo Sertão do Itamambuca

Prancha 8. Quilombo Caçandoca

Prancha 9. Quilombo Caçandoca

Prancha 10. Procedimentos metodológicos adotados

Prancha 11. Locais utilizados como pontos de desembarques - Ubatuba

Prancha 12. Praia de Picinguaba, Ubatuba

Prancha 13. Praia da Fazenda, Ubatuba

Prancha 14. Praia de Ubatumirim, Ubatuba

Prancha 15. Praia Barra Seca, Ubatuba

Prancha 16. Praia da Fortaleza, Ubatuba

Prancha 17. Praia da Lagoinha, Ubatuba

Prancha 18. Praia da Maranduba, Ubatuba

Prancha 19. Praia da Caçandoca, Ubatuba

Prancha 20. Locais utilizados como pontos de desembarques - Caraguatatuba

Prancha 21. Praia de Tabatinga, Caraguatatuba

Prancha 22. Locais utilizados como pontos de desembarques - São Sebastião

Prancha 23. Praia de Toque Toque Grande, São Sebastião

Prancha 24. Praia da Barra do Sahy, São Sebastião

Prancha 25. Praia da Barra do Una, São Sebastião

Prancha 26. Praia de Boracéia, São Sebastião

Prancha 27. Locais utilizados como pontos de desembarques - Ilhabela

Prancha 28. Praia dos Castelhanos, Ilhabela

Prancha 29. Praia da Figueira, Ilhabela

Prancha 30. Saco do Sombrio, Ilhabela

Prancha 31. Possíveis conexões - Ubatuba

Prancha 32. Gruta de Ubatumirim - Ubatuba

Prancha 33. Ilhota do Negro - Ubatuba

Prancha 34. Ruínas - Brava de Almada - Ubatuba 


\section{LISTA DE IMAGENS}

Imagem 1. Capa do livro sobre o negreiro Fredensborg

Imagem 2. Pesquisas subaquáticas realizadas na Baía de Angra dos Reis

Imagem 3. Pesquisas subaquáticas realizadas na Baía de Angra dos Reis

Imagem 4. Destroços do Trouvadore, no mar do Caribe

Imagem 5. Destroços do Trouvadore, no mar do Caribe

Imagem 6. Os destroços do Henrietta Marie

Imagem 7. Mergulhadores na área dos destroços do São José Paquete África

Imagem 8. Barras de ferro encontradas no naufrágio São José Paquete África

Imagem 9. Pesquisas subaquáticas realizadas nos destroços do James Matthews

Imagem 10. Vista do canal a partir de São Sebastião, com Ilhabela ao fundo

Imagem 11. Porto de São Sebastião, com Ilhabela ao fundo

Imagem 12. Apresentação da Congada de Bastões de São Benedito em 2013

Imagem 13. Apresentação da Congada de Bastões de São Benedito em 2013

Imagem 14. Evento realizado pela Ong Zambô

Imagem 15. Evento realizado pela Ong Zambô

Imagem 16. Detalhe dos atabaques adornados, em dia de toque no terreiro

Imagem 17. Entrega de Oferendas para lemanjá

Imagem 18. Exemplo de uma das edificações tombadas no centro histórico - Casa

Esperança

Imagem 19. Apresentação da Congada de São Benedito

Imagem 20. Samba de roda

Imagem 21. Congada de Ilhabela, 2016

Imagem 22. Página do Facebook mantida pela comunidade do Quilombo Camburi

Imagem 23. Página inicial do site do Quilombo da Fazenda

Imagem 24. Página do Facebook mantida pela comunidade do Quilombo da Fazenda

Picinguaba

Imagem 25. Seu Zé Pedro, na casa de Farinha no Quilombo da Fazenda Picinguaba

Imagem 26. Capa do livro de Moacir Pinto que retrata os "causos" de seu Zé Pedro

Imagem 27. Página do Facebook do Quilombo do Sertão de Itamambuca

Imagem 28. Bolas de canhão expostas pela passagem do furacão Matthew em uma praia da Carolina do Sul

Imagem 29. Bolas de canhão, no detalhe

Imagem 30. Embarcação na praia dos Castelhanos exposta na época do cadastro

Imagem 31. Local onde a embarcação foi localizada

Imagem 32. Banner da exposição temporária em frente ao MACC

Imagem 33. Itens da exposição - vestimentas de cultos africanos

Imagem 34. Itens da exposição - instalação para lemanjá, o orixá "dona do mar" 


\section{LISTA DE MAPAS}

Mapa 1. Litoral Norte de São Paulo

Mapa 2. Manuscrito com aquarela representado a Capitania de Santo Amaro de autoria de João Teixeira Albernaz datado de 1631

Mapa 3. Abrangência do Parque Estadual de Ilhabela

Mapa 4. Mapa antigo indicando a vila de Ubatuba e o local do antigo porto 


\section{LISTA DE FIGURAS}

Figura 1. Representação da fragata Fredensborg

Figura 2. Esboço do Hentietta Marie

Figura 3. Croqui dos destroços do James Matthews

Figura 4. Moenda de cana com tração animal

Figura 5. Folder de divulgação da capoeira

Figura 6. Comunidades quilombolas no município de Ubatuba

Figura 7. Tipos de ondas mais comuns

Figura 8. Correntes marinhas entre o continente sul-americano e africano

Figura 9. Engrenagens da pesquisa 


\section{LISTA DE TABELAS}

Tabela 1. Referências culturais associadas a herança africana nos municípios do litoral Norte paulista

Tabela 2. Sítios arqueológicos identificados no litoral Norte de São Paulo

Tabela 3. Remanescentes de comunidades quilombolas de Ubatuba

Tabela 4. Possíveis locais de desembarques e seu status

Tabela 5. Ancoradouros e abrigos no litoral Norte paulista

Tabela 6. Locais passíveis de desembarques e seus compartimentos avaliados. 


\section{INTRODUÇÃO}

Depois de um hiato de mais de quinze anos sem estudar, resolvi fazer uma graduação. Foi ainda nos primeiros semestres do curso em Oceanografia que o objeto de pesquisa que resultou nessa dissertação começou a ganhar forma. Nesse período, já estava lendo bastante sobre Arqueologia, sobretudo, os textos voltados a sua vertente 'molhada'. O encanto que o ambiente aquático exercia em mim, me motivou a optar pela graduação em Oceanografia, com o firme propósito de que essa formação me daria base para desenvolver uma pós-graduação em Arqueologia com um viés subaquático. Durante a graduação acabei cursando disciplinas no MAE, juntamente com um estágio que me permitiu trabalhar com o prof. Flávio Calippo no processamento das amostras de conchas para as análises de isótopos estáveis. Além disso, na monografia apresentada ao curso de Oceanografia já esbocei possíveis caminhos a serem trilhados utilizando ferramentas da Oceanografia na gestão do patrimônio cultural subaquático. Esse trabalho contou com a co-orientação do professor Calippo e foi importante para que eu começasse a organizar meu pensamento de forma interdisciplinar. Depois de formada, fui trabalhar na Zanettini Arqueologia e lá tive contato com diversas pesquisas arqueológicas voltadas ao licenciamento de empreendimentos diversos e pude com isso ampliar meus conhecimentos.

Nesse momento, o interesse pelo estudo de uma Arqueologia voltada a diáspora africana já vinha despertando, impulsionado principalmente pelos trabalhos desenvolvidos no Quilombo dos Palmares pelo prof. Pedro Paulo Funari. A partir dessas leituras direcionei minhas pesquisas para o ambiente costeiro e o lugar mis próximo de onde moro e que se apresentava com maior potencial para esses estudos, pelo menos naquele momento, era o litoral norte paulista. Essa região, que tantas vezes visitei nas últimas duas décadas, foi se revelando um local cheio de peculiaridades ambientais que, apontava diversos caminhos para uma abordagem arqueológica da diáspora africana. Após os contatos com o professor Funari e o aceite para a orientação, o projeto ganhou corpo. Os caminhos indicados por ele foram extremamente importantes e só vieram a somar para esse trabalho.

Ainda assim, os desafios impostos eram inúmeros, mas como poderá ser visto no decorrer desse texto, as inquietações e reflexões expostas demonstram um potencial significativo resultante da interlocução da Oceanografia com a Arqueologia. Nesse sentido, busquei caminhos que possibilitassem uma abordagem interdisciplinar e que eu 
pudesse utilizar as inúmeras ferramentas oceanográficas que abordam o ambiente costeiro. Dessa forma, o litoral norte paulista pensado como "ponto" de entrada, para o Vale do Paraíba Paulista, de centenas de africanos escravizados possibilitaria, a grosso modo, a utilização em conjunto dos parâmetros oceanográficos como facilitadores/dificultadores para abordagens arqueológicas.

Por isso, diante das inúmeras possibilidades de pesquisas arqueológicas que o litoral Norte paulista oferece, a escolha pelo viés de uma Arqueologia voltada à diáspora africana se dá no sentido de que esta região apresenta um alto potencial devido, principalmente, a sua localização privilegiada em relação ao Vale do Paraíba, cuja demanda por mão-de-obra em meados do século XIX, fomentou um significativo aumento nos desembarques clandestinos na região, utilizando, sobretudo, as bordas recortadas e enseadas ${ }^{1}$ ermas.

Nesse sentido, o recorte aqui proposto abarcará Ubatuba, Caraguatatuba, São Sebastião e Ilhabela, sendo esses os quatro municípios que compõe o litoral Norte do estado de São Paulo. Até o momento, somente no município de São Sebastião foram identificadas pesquisas acadêmicas que abordam a Arqueologia da Diáspora

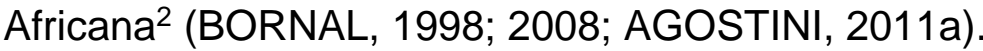

Apesar de o estado de São Paulo não ter historicamente abrigado grandes portos $^{3}$, devido provavelmente as "limitações da paisagem", vários locais foram utilizados para os desembarques de africanos escravizados. Importante salientar que a referência aos africanos escravizados, abarca impreterivelmente africanos e africanas, crianças, jovens, adultos e idosos que foram violentamente retirados de seus locais de origem e forçados a uma travessia transoceânica a fim de servirem de

\footnotetext{
1 A enseada é uma reentrância mais ou menos curva do litoral, constituindo um abrigo. É uma pequena baía (CHERQUES, Sérgio. Dicionário do mar. São Paulo: Globo. 1999. 550 págs.).

2 O sítio arqueológico São Francisco foi objeto de estudo no mestrado e no doutorado de Wagner Bornal, ambos defendidos no Museu de Arqueologia e Etnologia da USP. O sítio é um complexo construtivo e arquitetônico, sendo suas instalações associadas a uma fazenda na primeira metade do século XIX, tendo sido apresentado no mestrado o resultado de escavações, assim como a análise do acervo recuperado. No doutorado, Bornal fez uma abordagem do sítio São Francisco a partir dos preceitos da Arqueologia da paisagem, procurando entender o cenário da implantação do sítio (BORNAL, 1995, 2008). Camilla Agostini em seu doutorado, defendido no Departamento de História da Universidade Federal Fluminense, também tem como objeto de estudo o sítio arqueológico São Francisco e sua abordagem dedica-se a entender as dinâmicas materiais e simbólicas buscando "hipótese da ligação desta fazenda e seu proprietário com o tráfico ilegal de escravos, no segundo quartel do século XIX" (AGOSTINI, 2011a).

${ }^{3}$ A referência aos portos nesse trabalho se dará no sentido de uma área abrigada de ondas e correntes, localizada à beira de um oceano, mar, lago ou rio. Mesmo a utilização de portos clandestinos presente no decorrer desse trabalho, dar-se-á no sentido de um local de atracamento, onde a embarcação poderia permanecer ancorada para que o desembarque de africanos se efetuasse por meio de pequenas embarcações, ou, ainda, como no caso do Saco do Sombrio, onde provavelmente o desembarque se fazia de maneira direta, embarcação/terra.
} 
força de trabalho nas Américas ${ }^{4}$. Pressupõe-se que isso ocorreu por muitos anos pois e, por meio da leitura da paisagem, foi possível identificar que vários arranjos foram utilizados para que esses desembarques acontecessem, por isso, julgo importante tal investida, visto a conhecida utilização de mão-de-obra escrava na região, ademais, a abordagem desta temática em território paulista busca preencher uma lacuna de pesquisas sobre o tema, bem como realizar uma crítica à visão que o estado não teria sido palco de tráfico de contingentes expressivos de africanos.

Nesse sentido, objetivou-se a integração de fontes diversificadas, tais como, evidências materiais, indicadores da paisagem, narrativas orais, fontes secundárias e com especial atenção à Historiografia sobre o tema, foi possível traçar possibilidades interpretativas acerca da diáspora africana na região estudada. Como parte dessa pesquisa, foram realizadas três etapas de campo entre 2014 e 2016 que objetivaram, entre outras coisas, identificar por meio da leitura do ambiente e dos recortes nas bordas continentais de pontos específicos dos municípios abordados, características facilitadoras e/ou dificultadoras para os desembarques de africanos, estabelecendo, a partir de então, locais com potenciais para estudos arqueológicos, seja em meio terrestre ou em meio subaquático, mas também na zona de espraiamento ${ }^{5}$ e na interface entre terra mar, na zona entremarés ${ }^{6}$. Além de que nas etapas de campo foram estabelecidos diálogos com moradores das comunidades caiçaras e de comunidades quilombolas, a fim de colher referências quanto aos locais de memória associados à diáspora africana.

Dessa maneira, este trabalho apresenta a seguinte estrutura:

No capítulo 1 - Arqueologia da Diáspora: uma forma de olhar, apresento sucintamente o desenvolvimento do pensamento arqueológico acerca do tema a fim de embasar a presente pesquisa. A discussão trazida à baila aqui objetiva contextualizar a própria definição de Arqueologia e as implicações que essa

\footnotetext{
4 Trouxeram consigo, apesar de toda as adversidades, uma gama de conhecimentos, crenças e saberes que contribuíram para a formação do povo brasileiro.

${ }^{5}$ A zona de espraiamento pode ser identificada como aquela região da praia delimitada entre a máxima e a mínima excursão dos vagalhões sobre a face praial. Os processos do espraiamento, principalmente sua máxima excursão vertical, têm importância fundamental para a engenharia costeira e para estudos quantitativos por representarem as condições de contorno do ambiente praial e por determinarem os níveis máximos de atuação dos agentes hidrodinâmicos do surfe sobre a praia Disponível em http://www.cem.ufpr.br/praia/pagina/pagina. php?menu=praias\# acessado em 5 de novembro de 2016).

${ }^{6}$ Faixa entremarés - região entre a preamar e a baixa mar de sizígia.
} 
orientação teórica norteou. Da mesma forma a Arqueologia Histórica é apresentada buscando um viés descolonizador para entrar nas discussões conceituais da Arqueologia da Diáspora africana. Nesse item, serão apresentadas as diferenças terminológicas para o estudo de sítios relacionados a contextos escravistas.

No capítulo 2 - Diáspora Africana, Tráfico Negreiro e Escravidão adentram ao terreno da Arqueologia Brasileira é exposto um pouco da trajetória das primeiras pesquisas arqueológicas acerca do tema no Brasil, inicialmente visando à localização e caracterização de antigos quilombos como espaços de resistência. Nesse sentido, são indicadas algumas pesquisas arqueológicas realizadas no Brasil, a fim de obter um panorama geral das regiões que são, ou já foram, alvo de pesquisas relacionadas à Arqueologia da Diáspora africana. Ainda, é feito um apanhado breve dos trabalhos arqueológicos realizados nos antigos quilombos, como é o caso do Quilombo do Ambrósio em Minas Gerais e do Quilombo dos Palmares em Alagoas.

Já no capítulo 3 - O palco da pesquisa: o Litoral Norte Paulista, a região do estudo é sinteticamente caracterizada, abordando suas particularidades ambientais que tornam esse ambiente tão singular, além de uma introdução aos aspectos socioeconômicos que movem os quatro municípios. Uma breve apresentação das manifestações culturais é apresentada de maneira resumida, com a finalidade de identificar principalmente aquelas que remetem a contextos herdados dos africanos, como é o caso da congada, do maculelê, da capoeira, entre outros. Os sítios arqueológicos até agora identificados na área de pesquisa são apontados e revelam ocupações pretéritas na região em apreço. Foram também realizados diálogos pontuais nas comunidades quilombolas existentes no município de Ubatuba.

No capítulo 4 - Paisagens da Diáspora Africana: acerca da (in)visibilidade dos locais de desembarque e de refúgio, os levantamentos passam a ser feitos com fontes distintas de maneira mais marcada. Nesse sentido, as contribuições serão dadas por meio dos documentos históricos, pelas narrativas orais, pelos parâmetros oceanográficos e pelo olhar da Arqueologia. Dessa feita, esse capítulo apresenta algumas possibilidades resultantes da integração das informações obtidas, ousando propor caminhos que colaborem na leitura de locais com potencias para o estudo arqueológico. 
Ao final, são apresentadas algumas Considerações Finais em torno das possibilidades de abordagens arqueológicas sobre o patrimônio do litoral Norte paulista, principalmente aquele associado a diáspora africana. 


\section{CAPÍtUlo 1. ARQUEOLOGIA DA DIÁSPORA, UMA FORMA DE OLHAR.}




\subsection{Arqueologia: buscando conceituar}

Este capítulo compõe-se no sentido de que o percurso percorrido pela Arqueologia, principalmente no desenvolvimento das correntes teóricas que nortearam a disciplina, possibilitou uma somatória de abordagens e consequente expansão do campo de pesquisa. Com o passar do tempo, as contribuições dadas pelos vieses pelos quais a Arqueologia orientou-se desde o século XIX, possibilitaram novos caminhos, onde o artefato não é mais o único "objeto" de estudo da ciência arqueológica. Nesse sentido, apresento brevemente, alguns dos caminhos percorridos pela Arqueologia, a fim de proporcionar ao leitor um entendimento da proposta teórica por onde a presente pesquisa convergiu.

A Arqueologia enquanto disciplina composta por métodos e práticas só viria a constituir-se por volta da primeira metade do século XIX, quando começou a formulação das primeiras técnicas de escavação por meio de investigações próprias. O estudo da cultura material estava até então confinado aos antiquários e, a partir desse momento, começou a alcançar uma projeção que ia além do simples colecionismo.

Por volta do início do século XX, Gustaf Kossinna (1858-1931) cria o conceito de "cultura arqueológica", atribuindo um conjunto de conhecimentos, crenças, arte, moral, costumes e hábitos que eram adquiridos pelo homem em uma sociedade e perceptíveis através da escavação arqueológica (RIBEIRO, 2007). Por meio deste conceito, configurava-se um método eficaz de identificação e acompanhamento do desenvolvimento das culturas ao longo do tempo. Nesse sentido, Kossina teve importante papel no desenvolvimento da Arqueologia Histórico Cultural, no entanto, o alcance de suas ideias teve pouca influência fora dos países de língua alemã, isso se deu por causa do teor de suas interpretações nacionalistas da pré-história (TRIGGER, 2004).

Influenciado pelos pensamentos de Kossina, o australiano Gordon Childe, usando sua bagagem intelectual adquirida ao longo dos anos e desiludido com a política em 1921, retomou seus estudos de Arqueologia que resultaram na publicação 
de dois importantes livros ${ }^{7}$. Adotou o conceito de "cultura arqueológica" de Kossina, mas rejeitou todas as conotações racistas vinculadas a essas ideias (TRIGGER, 2004). Nesse sentido, a Arqueologia Histórico Cultural norteou a grande maioria das pesquisas durante o século XIX e XX (REIS, 2003) e, ainda de acordo com esse autor, a preocupação desse modelo está principalmente associada às pesquisas sobre os artefatos e a confecção das linhas gerais do tempo em relação aos eventos culturais. Centralizando suas atenções nos artefatos, justifica as mudanças sociais ao longo do tempo através de três possíveis caminhos: a invenção; a migração e a difusão.

Funari $(2005,1)$ sustenta que "o modelo histórico-cultural parte do pressuposto que a cultura seja homogênea e que as tradições passem de geração a geração" e, embora esse modelo tenha sofrido grandes modificações ao longo do tempo, ele continua sendo amplamente utilizado até os dias de hoje.

Mas, nos anos 1960, um novo movimento surge nos Estados Unidos, contrapondo-se ao modelo Histórico Cultural, a New Archaeology ou Arqueologia Processual. Esse movimento é liderado por Lewis Binford, que se empenhará obstinadamente na busca de ferramentas que objetivavam atribuir um caráter mais científico à Arqueologia, o que atualmente é bastante criticado (REIS, 2003). Baseado em referenciais da epistemologia, do positivismo lógico, da teoria dos sistemas e do neoevolucionismo, entre outros, Binford rejeitou as generalizações indutivas que eram fomentadas pelo modelo Histórico Cultural. Leslie White e Julian Steward influenciaram a Arqueologia Processual, o primeiro com teorias da Evolução Cultural e o segundo com a denominada Ecologia Cultural (REIS, 2003).

De acordo com Binford (1983), a Arqueologia é a ciência humana especializada em evidenciar, registrar e analisar os vestígios materiais em espaços determinados, com o intuito de examinar como se procedeu nestes lugares a ocupação humana ao longo do tempo. Para Funari (2005:2), a Arqueologia Processual "refletia bem uma visão capitalista do passado humano, privilegiando uma interpretação materialista pouco preocupada com as diversidades culturais".

No início dos anos de 1980, o arqueólogo inglês lan Hodder começa a tecer duras críticas a New Archaeology, baseadas principalmente na falta de uma teoria

\footnotetext{
7 The Dawn of European Civilization, (1925) e The Danube in Prehistory (1929).
} 
prática, excesso de funcionalismo, ausência da dimensão histórica, negligência quanto ao papel do indivíduo subordinado à organização mecânica do inconsciente, entre outras (HODDER, 1985). Uma das várias preocupações de Hodder (1992) está relacionada à necessidade de uma atualização teórica na direção de reconhecer o significado e o simbolismo como fatores chave na criação do registro arqueológico.

As críticas de Hodder e de outros arqueólogos estimularam a configuração de um novo paradigma, a escola Pós-Processual. A Arqueologia tomava novas direções e perspectivas, da ideologia, da cognição, do plural, onde todas as visões e posicionamentos tinham a mesma importância (FEINMAN \& PRICE, 2001). Esta corrente ficou caracterizada pelo fim das grandes narrativas, dos regionalismos e a adoção da multivocalidade. Para Symanski e Gomes (2013:295), uma das principais vantagens do pós-processualismo é "o reconhecimento de que as relações humanas são simultaneamente sociais e materiais".

Reis (2003) entende que a Arqueologia Pós-processual traz a dimensão dos significados simbólicos que irão variar e se destacar em contextos culturais diferentes e vem resgatar o significado cultural adquirido pela cultura material. Com variadas interpretações, Symanski e Gomes sugerem que o pós-processualismo não representa uma vertente teórica unificada, mas, é acima de tudo

(...) um rótulo genérico para uma diversidade de abordagens da teoria social contemporânea, as quais têm em comum a rejeição ao positivismo e ao objetivismo das abordagens ditas científicas que as precederam, como a arqueologia processual e a arqueologia comportamental (SYMANSKI \& GOMES, 2013:294).

A Arqueologia abrange diversas vertentes teóricas, no entanto, seus paradigmas epistemológicos em muitas situações não são bem conhecidos. Desde sua consolidação no século XIX, diversas teorias foram desenvolvidas e, de certa forma, todas continuam até hoje sendo utilizadas (FUNARI, 2005). Os avanços que a ciência arqueológica vem tendo nos últimos anos têm sido importantes para sua definitiva consolidação, conforme observa Paulo Zanettini, quando diz que

(...) de longe, acompanho os debates nos quais a Arqueologia é submetida a grandes questionamentos do ponto de vista epistemológico. Vejo-a revigorada, superando limites que the eram impostos, a fim de conquistar sua merecida posição no panteão das Humanidades. Pode-se dizer que a disciplina conhece uma verdadeira revolução, tornando-se cada vez mais rica, plural, multifacetada e amadurecida sob a égide da Pós-Modernidade (ZANETTINI, 2005:5). 
Nesse sentido, a Arqueologia vivenciou ao longo do tempo mudanças que permitiram uma maior abrangência de seu locus. Passando por uma corrente teórica centrada principalmente no artefato, depois para outra que visava atribuir um caráter científico à Arqueologia e, por isso, cercou-se de aparatos que possibilitaram um maior controle sobre o registro arqueológico. E a partir dos anos 1980, com o enfoque pósprocessual, a Arqueologia vivenciou uma ampliação de seu campo, passando o indivíduo a ter um papel primordial nas escolhas, com a atribuição de significados como fator principal na criação do registro arqueológico.

A partir disso, a presente dissertação parte do entendimento da Arqueologia como uma ciência que estuda as sociedades humanas por meio de sua cultura material,

(...) isto é, aquele segmento do universo físico que é socialmente apropriado pelo homem e que engloba tanto objetos, utensílios, estruturas como a natureza transformada em paisagem e todos os elementos bióticos e abióticos que integram um assentamento humano" (MENESES, 1987:186).

Dessa forma, a proposta teórica converge para o entendimento da Arqueologia como uma ciência social voltada ao estudo de sociedades humanas, aqui orientada por uma interpretação da paisagem, como componente intrínseco do registro arqueológico. Passando pela inserção de outros componentes oriundos de áreas como a História e a Oceanografia e que possibilitaram um olhar para o estudo da cultura material, permitindo leituras que ultrapassam a "materialidade".

\subsection{Arqueologia Histórica: procurando descolonizar}

Se a Arqueologia alcançou seu reconhecimento enquanto ciência a partir do século XX, a Arqueologia Histórica vem galgando seu espaço desde então, mas, começou a ganhar corpus já no final do século passado, conforme afirma Funari,

Os últimos anos testemunharam uma verdadeira revolução no campo da Arqueologia Histórica internacional, destacando-se, em particular, a realização, pela primeira vez com esse nome, de um tema intitulado Changing Perspectives on Historical Archaeology, no contexto do World Archaeological Congress 3, realizado, em Nova Delhi, em dezembro de 1994 (FUNARI, 1996a:163). 
Nesse sentido, a Arqueologia Histórica assumiu um caráter importante enquanto disciplina e teve de forçosamente percorrer um extenso caminho na América nos últimos 40 anos para delimitar seu campo de atuação, potencialidades e instabilidades. Nesse caminho, acabou por receber inúmeras definições e conceituações que refletem, em última instância, as sucessivas etapas de amadurecimento teórico e metodológico pelos quais passou a Arqueologia como um todo (ORSER, 1992; LIMA, 1985, 1993, 1996; FUNARI, 1999, 2001; ZARANKIN, 1999; ZANETTINI ARQUEOLOIGA, 2015, entre outros).

Na tentativa de escapar do etnocentrismo ou eurocentrismo que lhe foi flagrante em sua forma inicial, a Arqueologia Histórica deixou de dedicar-se exclusivamente às marcas da expansão material europeia e sua adaptação ao solo americano (HARRINGTON, 1955; HUME, 1969; FONTANA, 1965; DEETZ, 1996), passando a incorporar paulatinamente o outro e, na sequência, reincorporando as vozes da África transplantada (FAIRBANKS; MILANICH, 1987) e as chamadas minorias e grupos marginalizados, reconhecendo seu lugar na História (DEAGAN, 1996:25). O fato de proporcionar imagens alternativas para o reexame e construção de identidades nacionais, distintas daquelas oferecidas pela história oficial no mundo globalizado, talvez tenha sido uma das maiores contribuições da Arqueologia Histórica para as histórias da Américas (STOVEL, 2005). Em decorrência da consolidação de seu discurso, a Arqueologia Histórica na América prosseguiu num caminho extremamente frutífero que conduziu à sua emancipação (ZANETTINI ARQUEOLOIGA, 2015).

No mesmo período em que ocorreu o WAC na Índia, dois importantes livros sobre Arqueologia Histórica em língua inglesa foram lançados por Charles Orser. Antes disso, no Brasil, Orser ${ }^{8}$ lança um livro em língua portuguesa e traz uma introdução à Arqueologia Histórica que, entre outros tópicos, traz definições da

\footnotetext{
"Arqueologia Histórica, sua história, os sítios e artefatos, as noções de tempo e espaço, as prospecções, o trabalho de campo, as teorias explicativas, os grupos, sua difusão pelo globo e a dimensão política deste campo de estudo" (FUNARI, 1996a:165-166).
}

\footnotetext{
8 ORSER Jr., Charles. Introdução à Arqueologia Histórica. Belo Horizonte: Oficina de Livros, 1992.
} 
Costa (2010) aponta o caráter, muitas vezes questionado da Arqueologia Histórica, de ser "um exercício de construção do passado, mas ao mesmo tempo uma ferramenta de desconstrução do presente" (Op. cit.:11).

Diante de questionamentos em relação ao caráter da Arqueologia Histórica, Funari afirma que a Arqueologia Histórica ainda é associada ao estudo das sociedades que possuíam registros escritos. No entanto, nos últimos 20 ou 30 anos, muitos debates foram gerados a fim de afastar o papel "suplementar de história subordinada" que a Arqueologia Histórica possuía.

Mais recentemente, dando prosseguimento a essa linha de pensamento, a partir da preocupação com a análise dos processos sociais e culturais do passado, arqueólogos históricos têm focado na expansão européia e no colonialismo, nos mecanismos relacionados de dominação e de resistência, e nas formas econômicas e políticas daí geradas, particularmente o avanço do capitalismo (FUNARI, 2007:52).

Como se observa, a Arqueologia Histórica vem experimentando várias interpretações conceituais que visam a uma aparente delimitação do seu escopo, mas, de acordo com Santaella, (1983:9), "toda definição acabada é uma espécie de morte, porque, sendo fechada, mata justo a inquietação e curiosidade que nos impulsionam para as coisas que, vivas, palpitam e pulsam", nesse sentido,

(...) não há uma única definição para a Arqueologia Histórica que inclua todas as possibilidades de investigação e que seja aceita unanimemente entre todos os arqueólogos. A própria delimitação do campo de estudo e a abrangência da Arqueologia Histórica Brasileira está em conceituação e discussão, como todo campo de pesquisa em construção (LIMA, 1989; FUNARI, 1996 apud HERBERTS, 2009:39).

Ainda, de acordo com Orser (2000:6) o fato de existir uma disciplina chamada Arqueologia Histórica, pode deixar parecer que existe um consenso em relação a sua definição, mas, não é isso que se observa, pois, de acordo com o autor

(...) es fácil pensar que posee una única definición con la que todo el mundo acuerda. Infelizmente éste no es el caso, ya que existen diferentes formas de caracterizar este campo. Para explicar las divergencias, debo antes exponer la naturaleza del problema" (ORSER, 2000:6)

O desenvolvimento da Arqueologia Histórica no Brasil inicia-se no final de 1930 com pesquisas desenvolvidas por Kruse e Souza, surgem ainda de maneira pontual nas décadas de 40, 50 e 60, conforme pontua Lima (1993) em levantamento feito 
sobre o desenvolvimento da Arqueologia Histórica no Brasil intitulado "Arqueologia Histórica no Brasil: balanço bibliográfico (1960-1991)". De acordo com a autora,

(...) foi apenas no início dos anos 60 que a Arqueologia Histórica emergiu formalmente reconhecida como um campo de pesquisa através de investigações conduzidas por arqueólogos pré-historiadores em sítios históricos. A disciplina a esta época fortalecida pelos dispositivos da recém criada lei n. 3.924 entrava em uma fase de grande dinamismo com a implementação de pesquisas por todo o país (LIMA, 1993:226).

Depois disso, inúmeros trabalhos de Arqueologia Histórica foram desenvolvidos no Brasil que versavam sobre os mais variados temas, indo desde as pesquisas com vestígios submersos, desenvolvidas por Ulisses Pernambucano na década de 1970, passando pelos trabalhos de Marcos Albuquerque, desde o final da década de 1960, às pesquisas na cidade de São Paulo levadas a cabo por Margarida Andreatta. Nesse balanço, Lima (1993) reuniu indicações de inúmeros trabalhos relacionados a Arqueologia Histórica e, desde sua publicação em 1993, novos trabalhos foram e vem sendo produzidos, sendo a Arqueologia Histórica hoje um campo em franca ascensão.

Em um trabalho publicado em 2010, Symanski e Zanettini argumentam que a Arqueologia Histórica "encontra-se numa posição privilegiada para resgatar a agência dos grupos excluídos, e assim construir uma história mais inclusiva" (SYMANSKI \& ZANETTINI, 2010:115). Ainda, de acordo com os autores, isso se dá pelo fato de que a produção de conhecimento por meio das remanescentes materiais, principalmente aqueles relacionados à prática cotidiana, trazem informações importantes e podem confirmar ou refutar os documentos escritos pelos grupos dominantes.

Esse processo consecutivo de reflexão e renovação oferece um largo horizonte repleto de possibilidades, apresentando-se hoje a Arqueologia Histórica como uma ciência rica e multifacetada, conectada por correntes diversas com objetivos distintos, complementares, e não excludentes, "em condições de trabalhar com múltiplos passados, descobertos, interpretados, inventados ou recriados" (ZARANKIN \& SENATORE, 2002:12; ZANETTINI ARQUEOLOGIA, 2015). 


\subsection{Arqueologia da Diáspora: uma forma de olhar}

Na consulta bibliográfica identifiquei que não existe um consenso sobre o uso de Arqueologia da Escravidão ou Arqueologia da Diáspora Africana, Arqueologia Afroamericana, Arqueologia Afro-brasileira, Arqueologia dos sítios escravos, "enfim, estes se confundem muitas vezes, ficando no limiar entre problemas terminológicos e conceituais" (ROSA, 2010:63). No entanto, de acordo com Carvalho (2012) convencionou-se reunir pesquisas no contexto de escravidão sob a designação de Arqueologia da Escravidão ou, o que se deu mais recentemente, Arqueologia da Diáspora Africana. Ainda é possível encontrar esses conceitos referenciando sua origem, como por exemplo, à Arqueologia afro-brasileira, afro-americana, afrocaribenha. De acordo com Carvalho (Op. Cit. 2012:12), todas essas ramificações podem também ser incluídas na "Arqueologia da Resistência", atualmente definida, todavia, observa-se que não se trata apenas de nomenclatura, pois referem-se a orientações metodológicas diferentes.

Para Orser (2002), a Arqueologia da Escravidão se preocupa com o estudo dos vestígios identificados no interior das senzalas e de suas áreas de descartes nos limites de fazendas e, quando as investigações arqueológicas passam a se preocupar com outros locais, como os antigos quilombos, residências urbanas, assentamentos de africanos escravizados e negros livres, além de locais de práticas religiosas, outro termo passa a ser utilizado - a Arqueologia da Diáspora Africana (ORSER, 2002 apud BORBA, 2014).

Para Allen (2013), em pesquisas em desenvolvimento na região serrana dos Quilombos nos estados de Alagoas e Pernambuco, a Arqueologia da Diáspora Africana objetiva o entendimento da dispersão global dos africanos e seus descendentes fora da África, necessariamente em virtude da escravidão. Para Funari9 (com. pess. 2013), a Arqueologia da Diáspora Africana abarca as evidências materiais dos africanos escravizados tanto em seu contexto "aprisionado" - como é o caso dos engenhos, das senzalas, das fazendas, dos fatos associados ao comércio/tráfico negreiro, como em contextos não escravizados e/ou de resistência, como nos

\footnotetext{
${ }^{9}$ Comunicação pessoal realizada durante a disciplina "Perspectivas atuais da Arqueologia Histórica" ministrada no Museu de Arqueologia e Etnologia da USP em 6/09/2013.
} 
quilombos, nas manifestações religiosas e culturais, na dispersão desses grupos e de seus descendentes no território, entre outros.

O surgimento do conceito de diáspora africana no final da década de 70 , de acordo com Singleton e Souza (2009, apud ROSA, 2012:23), "logo foi incorporado pelas ciências humanas e sociais para definir a dispersão mundial dos africanos e afrodescendentes fora da África, seja pela escravidão ou por outras migrações".

Para Ferreira (2009a),

(...) o estudo arqueológico da diáspora africana permite delinear a diversidade de identidades culturais que os escravos forjaram na América. Permite, ainda, circunscrever os espaços de formação das comunidades escravas e os distintos universos multiculturais que construíram. As comunidades escravas da América, com efeito, não se formaram apartadas do mundo que as cercava, como se estivessem engolfadas num mar de pureza cultural (FERREIRA, 2009a:269).

A Arqueologia da Diáspora Africana surgiu nos Estados Unidos, a partir dos anos 1960, quando alguns arqueólogos que estavam pesquisando as treze colônias e as plantantions identificaram a cultura material deixada pelos africanos escravizados e se dedicaram à tarefa de descrever os artefatos encontrados (SINGLETON e BOGRAD, 1995 apud FERREIRA, 2009b). Essa vertente da Arqueologia preocupase com algumas questões específicas relacionadas ao tema, entre elas, por exemplo, a busca de naufrágios de navios negreiros (WEBSTER, 2008), mas, acima de tudo, considera a História multicultural do Atlântico.

Importante destacar que, apesar do termo da Arqueologia da Diáspora Africana ter sido cunhado depois que os estudos da Arqueologia da Escravidão haviam dado os primeiros passos, entendo que esse termo pode abarcar de maneira mais consistente as especificidades do tema e permite delinear a diversidade de identidades culturais que os africanos escravizados forjaram no novo mundo. Por isso, vou considerar nesse trabalho todos as abordagens arqueológicas associadas ao período da escravidão, aos africanos na condição de escravos e na resistência, além dos estudos etnoarqueológicos realizados nas comunidades quilombolas atuais, como Arqueologia da Diáspora Africana.

De acordo com Mamigonian, os descendentes de africanos nas Américas têm mostrado um interesse renovado e contam com “(...) inédita colaboração entre 
africanistas e especialistas nas populações negras nas Américas e em outros continentes que apontam para uma "redescoberta" da África espalhada pelo mundo" (2004:33).

Dos africanos escravizados trazidos para o novo mundo, o Brasil recebeu um contingente bastante expressivo e, por tratar-se de um deslocamento forçado, a resistência a essa nova condição imposta foram constantes durante todo o período de vigência do sistema escravista. Para Souza (2013a), "um dos traços mais salientes dessa arqueologia, está no fato dela envolver deslocamento forçado, e em escala global, de um número muito alto de pessoas" e, até hoje, de acordo com o autor, os principais vestígios estudados pela Arqueologia da Diáspora Africana tem sido os vestígios cerâmicos e os remanescentes arquitetônicos.

No entanto, como foi possível observar, alguns caminhos têm sido trilhados pelos pesquisadores interessados no estudo da Arqueologia da Diáspora Africana. De acordo com Carle, ainda há muito a ser feito em relação aos estudos arqueológicos que enfoquem os africanos que aqui chegaram por meio da escravidão e seus descendentes, pois, segundo o autor, a história da Arqueologia

(...) é em si a história do esquecimento das comunidades não indígenas e não europeias, pois esta se dedica a muito a estudar estas duas e desvia o foco das comunidades africanas que para cá foram trazidas chegando a representar em certa época 70\% da população (CARLE, 2005:67).

Almeida (2012:28) aponta as peculiaridades do registro arqueológico dos grupos escravos quando diz que os "escravos podem ter usado alguns objetos aparentemente utilitários - como potes e cachimbos de barro - para promover coesão de grupo e identidade própria". Para que tal situação seja identificada, é necessário um maçante exercício de interpretação por parte dos arqueólogos, pois a cultura material não é um mero reflexo passivo, mas é utilizada instrumentalmente por diferentes grupos sociais com uma série de propósitos, que de acordo com Symanski \& Gomes, vão desde a "imposição de ideologias, a resistência a sistemas opressivos, e a construção, afirmação e reprodução de identidades diferenciadas" até a inclusão de classe, gênero, grupos etários e etnicidade (SYMANSKI \& GOMES, 2013:294).

Os estudos arqueológicos da diáspora africana buscam, em suma, entender como as identidades culturais dos africanos escravizados nas Américas se expressam materialmente em vários contextos (FERREIRA, 2009a) e, de acordo com Agostini, 
ainda se pode contar com "a possibilidade de abordar múltiplas vozes em vestígios materiais, a arqueologia contribui com os estudos históricos que, muitas vezes, dependem apenas de versões oficiais, escritas" (AGOSTINI, 2011a:9).

De acordo com Costa (2016), atualmente a busca pela cultura material ligada a grupos africanos e afro-descentes também

(...) se diversifica para outros contextos, como espaços urbanos, lixeiras coletivas, unidades domésticas, arraiais de mineração, fazendas de café, gado e charque, cemitérios, paisagens e portos. Assim como a multiplicidade de abordagens que tem surgido, desde os olhares inter, multi, pluri e transdisplinares até profusão de novas fontes de investigação (COSTA, 2016:74).

Em função dessa multiplicidade de abordagens, novos trabalhos têm surgido a cada ano, colaborando no fortalecimento dessa linha de pesquisa e fomentando a geração de novos olhares acerca dos vestígios arqueológicos associados a diáspora africana.

\subsubsection{A contribuição da Arqueologia Subaquática}

Não se pode falar em tráfico de escravos sem falar na sua principal "entidade", o navio negreiro. Era dentro dessa "entidade", (...) que o tráfico se tornava real (REDIKER, 2011).

A arqueóloga britânica Jane Webster organizou uma edição especial do International Journal of Historical Archaeology em comemoração aos 200 anos ${ }^{10}$ de abolição do tráfico de africanos escravizados na Inglaterra. A temática era a Arqueologia dos transportes de escravos, com ênfase nos navios negreiros. De acordo com Rambelli (2013), a autora chama a atenção "para o vazio nessa área de produção do conhecimento arqueológico e o representa empiricamente: são apenas cinco capítulos, sendo dois deles sínteses da própria organizadora da publicação" (RAMBELLI, 2013:208).

Os navios "eram meios vivos pelos quais se uniam os pontos naquele mundo Atlântico. Eles eram os elementos móveis que representavam o espaço de mudança

\footnotetext{
${ }^{10}$ Em primeiro de outubro de 1807 o Parlamento britânico aprova o Abolition Act, que proibia o tráfico de escravos na Inglaterra.
} 
entre os lugares fixos que eles conectavam" (GILROY, 2002:60) e, nesse sentido, devem ser pensados como unidades culturais e políticas. Mas, muitas vezes não são considerados e, para Webster (2008), a arqueologia de navios negreiros acaba recebendo menos atenção que a arqueologia dos modos de vidas dos africanos escravizados nas Américas. Isso se dá, muitas vezes, porque se entende a passagem do meio como apenas o começo de uma história maior, que é a diáspora africana (WEBSTER, 2008).

Nesse sentido, Alberto Costa e Silva salienta que

(...) mesmo com relação a esse navio, nunca pus os olhos num estudo sistemático a ele dedicado, no qual se recolhessem, analisassem e completassem as informações que temos dispersas sobre a evolução, ao longo de mais de trezentos anos, dos tipos e tamanhos das embarcações empregadas no tráfico, seu fabrico, suas tripulações, sua logística e o manejo econômico (SILVA, 2003:79).

De uma maneira geral, as pesquisas realizadas até agora nos destroços das embarcações negreiras têm trazido algumas informações e, dessa maneira, permitido a formulação de algumas hipóteses relativas a aspectos particulares da vida a bordo ${ }^{11}$.

Poucos naufrágios de embarcações negreiras foram alvo de estudos pela Arqueologia, sendo essas pesquisas com diversos graus de aprofundamento. Das seis embarcações que irei abordar, muito provavelmente, um dos sítios mais estudado foi o tumbeiro inglês Henrietta Marie, que naufragou na costa da Flórida em 1700. As outras cinco embarcações associadas ao comércio negreiro foram ou estão sendo alvo de pesquisas arqueológicas ${ }^{12}$ no momento. Como o caso do Trouvadore, identificado no mar do Caribe, próximo as ilhas Turcas, e Caicós, com pesquisas que ainda estão em curso. O Fredensborg, uma fragata naufragada na Noruega na segunda metade do século XVIII, também foi alvo de pesquisas arqueológicas. Um caso de uma embarcação negreira que naufragou quando já tinha sido modificada é o James Matthews (antigo Dom Francisco), sendo que seu passado de uso no tráfico não foi esquecido e os destroços resultantes do naufrágio na costa da Austrália foram identificados e pesquisados.

\footnotetext{
${ }^{11}$ Mais adiante essa informação será retomada, usando como exemplo o caso do Fredensborg.

12 Entenda-se aqui que o fato de pesquisas arqueológicas estarem acontecendo não significa que se referem apenas ao sítio de naufrágio, pode-se considerar os estudos dos artefatos recuperados e cujo estudo ainda estão em andamento.
} 
Três desses sítios arqueológicos de naufrágios constam no "Slave Wreck Heritage", sendo que esse projeto busca dar mais visibilidade aos estudos dos navios negreiros, alegando que "apesar da rápida proliferação de estudos históricos, antropológicos e arqueológicos de vários aspectos do comércio de escravos africanos, é notável como poucos estudos arqueológicos dos restos dos navios envolvidos nesse comércio têm sido conduzidos até agora ${ }^{13 " . ~}$. Apesar de não existir nenhuma referência neste site (http://www.slavewrecksproject.org/) do trabalho desenvolvido por Gilson Rambelli em Angra dos Reis, ao tentar localizar os destroços do brigue Camargo, esse estudo foi incorporado a esta dissertação. Vale ressaltar que, apesar dos destroços não terem sido localizados, esse trabalho foi importante pois as ações empreendidas na busca acabaram por inserir as pesquisas em naufrágios de navios negreiros nas possibilidades de abordagens arqueológicas no Brasil.

E recentemente, em 2015, foram identificados destroços de uma embarcação negreira naufragada na costa africana, o São José Paquete África. Assim, o quadro atual é de que seis naufrágios associados a embarcações envolvidas no comércio de africanos escravizados foram alvo de pesquisas arqueológicas. Se considerarmos que foram realizadas em torno de 35.000 viagens para as Américas, com uma estimativa de que aproximadamente 276 embarcações naufragaram, isso significa que pouco mais de $2 \%$ desse total foi alvo de pesquisas (ELTIS, 2010). Outra fonte aponta um número mais expressivo de embarcações naufragadas, indicando que soçobraram algo em torno de 580 embarcações (http://www.slavewrecksproject.org/). Santos (2015) supõe que mais de 600 embarcações utilizadas no transporte de africanos escravizados naufragaram durante as travessias entre o continente africano e as Américas. Considerando essa estimativa, o contraste com o número de pesquisas torna-se ainda mais chocante. No entanto, deve-se considerar a dificuldade de identificar esse tipo de sítio, pois, quando se encontra em um ambiente totalmente submerso, o próprio acesso ao sítio já reduz drasticamente as possibilidades de localização. E quando um sítio de naufrágio é localizado, a incrustação pode modificar significativamente a aparência dos destroços e, além de todos os fatores pósdeposicionais a que estão expostos os vestígios em ambiente submerso, os destroços

13 Texto original "Despite the rapid proliferation of historical, anthropological, and archaeological studies of various aspects of the global African slave trade, it is remarkable how few archaeological studies of the remains of the ships engaged in that trade have been conducted to date". Disponível em http://www.slavewrecksproject.org/. Acessado em 26 de outubro de 2016. 
ainda podem se espalhar, em função das correntes de fundo, por exemplo, por centenas de metros ou até mesmo por quilômetros, dificultando sobremaneira a identificação do sítio.

Nesse sentido, utilizando as informações de pesquisas sobre naufrágios de navios negreiros até agora divulgadas, gerei uma espacialização aproximada das embarcações ao redor do mundo (Prancha 1). 
PRANCHA 1. Pesquisas arqueológicas em sítios de naufrágios de navios negreiros

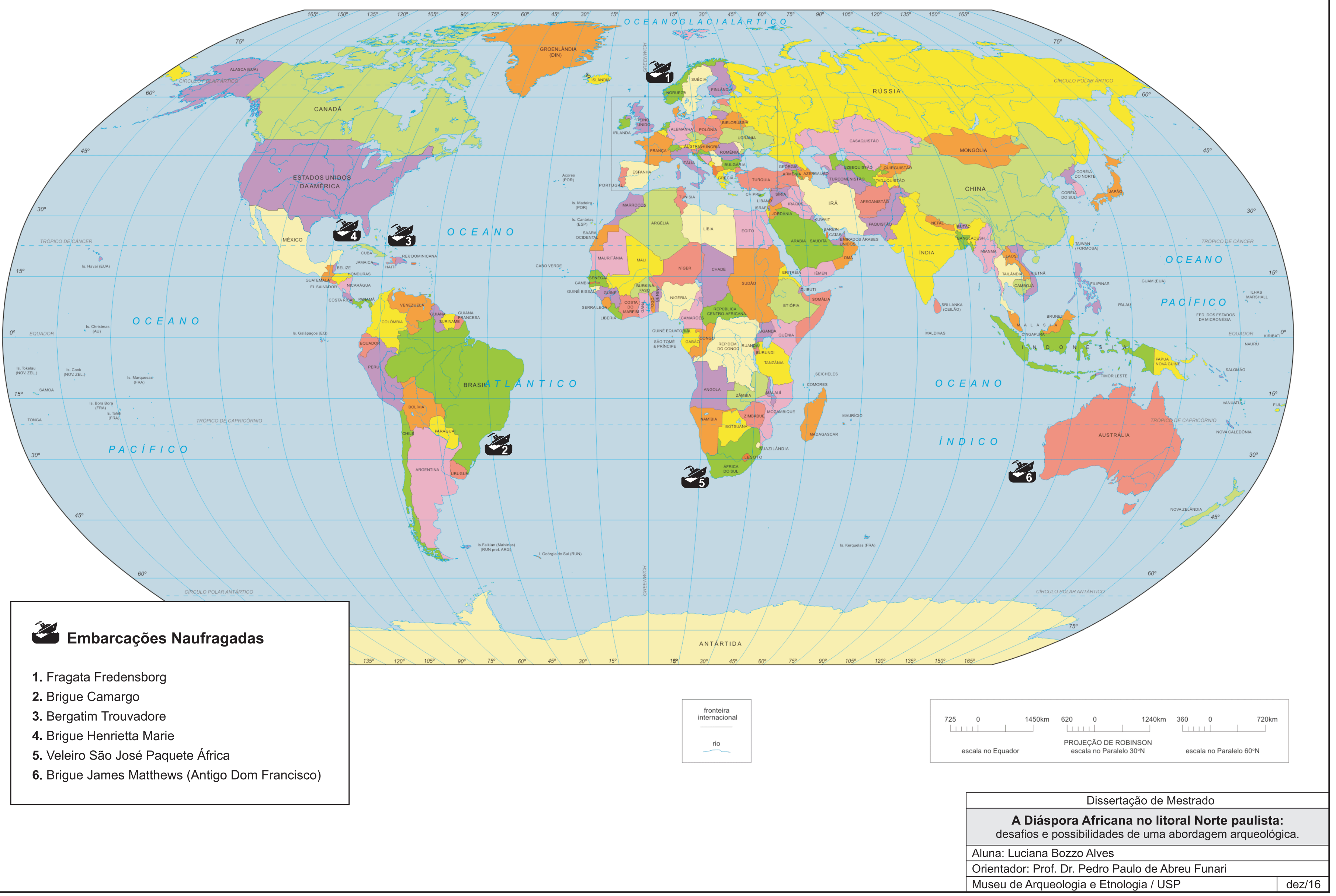


Como se observou na prancha 1, quatro $(2,3,4$ e 5$)$ das seis embarcações indicadas no mapa foram localizadas entre o continente africano e as Américas. Uma embarcação (1) foi localizada na Noruega e, segundo Leif Svalesen, o fato dessa embarcação ter sido localizada acabou por inserir os povos nórdicos no comércio negreiro. E a última, completamente deslocada do "eixo" África/Américas é uma embarcação que, depois de muitos anos no comércio negreiro, foi adaptada para o comércio mercante, mas, mesmo assim, as pesquisas em seu sítio de naufrágio consideram seu passado "negreiro". Dessa forma, a seguir, é apresentada uma breve síntese de cada embarcação negreira naufragada que foi alvo de pesquisas.

\section{Fragata Fredensborg}

O navio afundou em águas rasas na costa Sul da Noruega ao largo de Arendal. Acredita-se que isso se deu em $1^{\circ}$ de dezembro de 1768, após uma grande tempestade que o surpreendeu. Os destroços da embarcação foram encontrados e devidamente identificados em setembro de 1974 por uma equipe de pesquisadores. Fazia parte desse grupo um pesquisador norueguês, Leif Svalesen, que posteriormente escreveria um livro com a história da embarcação, além de apresentar os trabalhos efetuados nos destroços.

As pesquisas realizadas nos destroços identificaram um amuleto e um pilão de pedra para grãos. De acordo com Rambelli (2013:2009), "esses artefatos chamam a atenção para a manutenção da vida "religiosa" a bordo e para o preparo de alimentos com características pouco europeias". A identificação dessas evidências pode apontar para estratégias utilizadas pelos traficantes que visavam, por meio da permissão da presença desses itens, minimizar as chances de revoltas e, quem sabe, minimizar as perdas de vidas.

Acredita-se que o tráfico de escravos dinamarquês-norueguês tenha trazido para as Américas cerca de 100.000 africanos (SVALESEN, 2000).

Com isso, o autor acabou por abordar a participação dos povos escandinavos no comércio negreiro. Essa obra foi publicada no ano 2000 pela Indiana University Press, com patrocínio da UNESCO, e intitula-se The Slave Ship Fredensborg. 


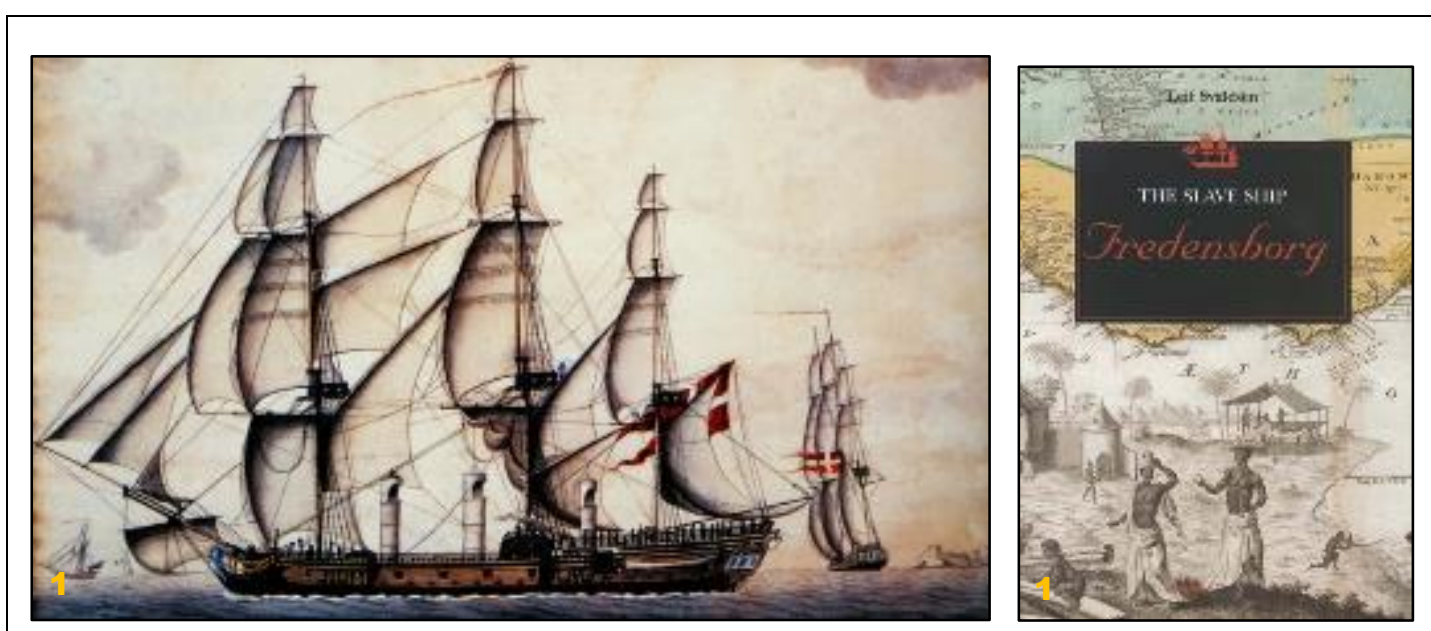

Figura 1. Representação da fragata Fredensborg (Leif Svalesen, The Slave Ship Fredensborg, translated by Pat Shaw and Selena Winsnes (Kingston, Jamaica: Ian Randle publishers, 2000), p.

104; original in The Danish National Archives, Copenhagen) Imagem 1. Capa do livro sobre o negreiro Fredensborg, de autoria de Leif Svalesen, (Kingston, Jamaica: Ian Randle publishers, 2000).

\section{Brigue Camargo}

O Brigue ${ }^{14}$ Camargo foi considerado como um dos últimos navios negreiros a desembarcar africanos escravizados com sucesso no Brasil, a bibliografia historiográfica aponta que provavelmente os desembarques aconteceram até 0 ano de 1870 (LEITE, 1998; BOCCIA e MALERBI, 1977), no entanto, não existem comprovações precisas desses desembarques. Vale ressaltar que o desembarque do Camargo se deu em terras dos comendadores Souza Breves, sendo que esses senhores foram apontados em vários processos de apreensão de navios negreiros durante o período de ilegalidade do tráfico (LOURENÇO, 2013).

O desembarque do Camargo, ocorrido em dezembro de 1852, nas terras da Fazenda Santa Rita de Bracuí, no município de Angra dos Reis, teve grande repercussão na época, de acordo com Rambelli e Nunes,

O episódio repercutiu significativamente na época, pelo fato de o brigue ter sido considerado um dos últimos navios que desembarcaram escravos com sucesso no Brasil. Curiosamente, seu comandante, o também norteamericano Nathaniel Gordon, do Maine, depois de dez anos do feito em águas brasileiras, se tornaria o primeiro e único traficante a ser executado nos Estados Unidos (RAMBELLI e NOVAES, 2011:3).

\footnotetext{
14 Embarcação de dois mastros com cestos de gávea, difere de escuna de gáveas que tem só vãos e pequenas gáveas de brim, com armação à latina. Informação extraída do Diccionario de Marinha, etc. Por João Pedro d'. Amorim. Disponível em http://books.google.com.br/books, acessado em 06 de agosto de 2014).
} 
Se Marta Abreu (1995) traz informações do Diário do Rio de Janeiro de 11 de dezembro de 1852 sobre boatos de um desembarque ilegal, o aludido ato ocorreu dias antes da referida reportagem ${ }^{15}$. O fato exposto traz informações sobre o desembarque do Camargo e sobre o deslocamento dos africanos escravizados recém-chegados que teriam imediatamente sido levados a subir a serra em direção as lavouras de café do Vale do Paraíba. Muitos foram os desdobramentos que resultaram desse episódio, as esferas políticas, públicas e policiais se mobilizaram para que o desembarque do Camargo e sua "carga humana"16" não ficassem sem punições, tal situação colocou o governo numa posição delicada, pois caso uma atitude efetiva não fosse tomada que resultasse na recuperação dos boçais ${ }^{17}$ e na condenação dos envolvidos, por exemplo - cairia em descrédito. Por isso, as ações empreendidas no caso visavam tornar o episódio de Bracuí um exemplo no combate ao tráfico de africanos escravizados.

A tentativa de localizar e identificar os destroços do brigue Camargo consistiram do pós-doutorado de Gilson Rambelli ${ }^{18}$. Foram feitos trabalhos de campo a fim de localizar os destroços, visto contar com informações oriundas de textos historiográficos e também de um levantamento dos naufrágios ${ }^{19}$ na baía de llha Grande. Apesar das investidas, alguns dos vestígios localizados não puderam ser confirmados como pertencentes a referida embarcação.

\footnotetext{
15 Dependendo da periodicidade do Diário do Rio de Janeiro, o desembarque pode ter acontecido dias ou mesmo uma semana antes da reportagem.

${ }^{16}$ A definição de "carga humana" é limitada para dar vazão à contribuição social, cultural, econômica, tecnológica, religiosa e política dada por milhares de indivíduos - crianças, mulheres, homens, idosos - que desembarcaram nos portos brasileiros e por toda a América ao longo de séculos de navegação. Gilson Rambelli; Luciana de Castro Nunes Novaes. Frutos do mar. Revista de História (Rio de Janeiro), v. 1, p. 29-32, 2011.

17 Africanos recém-chegados da África e que não falavam português.

${ }^{18}$ Arqueologia subaquática de um navio negreiro: a história que não está nos livros, desenvolvida no Núcleo de Estudos Estratégicos da Universidade Estadual de Campinas (NEE/Unicamp), sob supervisão de Pedro Paulo Abreu Funari.

${ }^{19}$ GALINDO, José E. R. Guia dos naufrágios da baía de Ilha Grande. São Paulo: Um, 2001.
} 


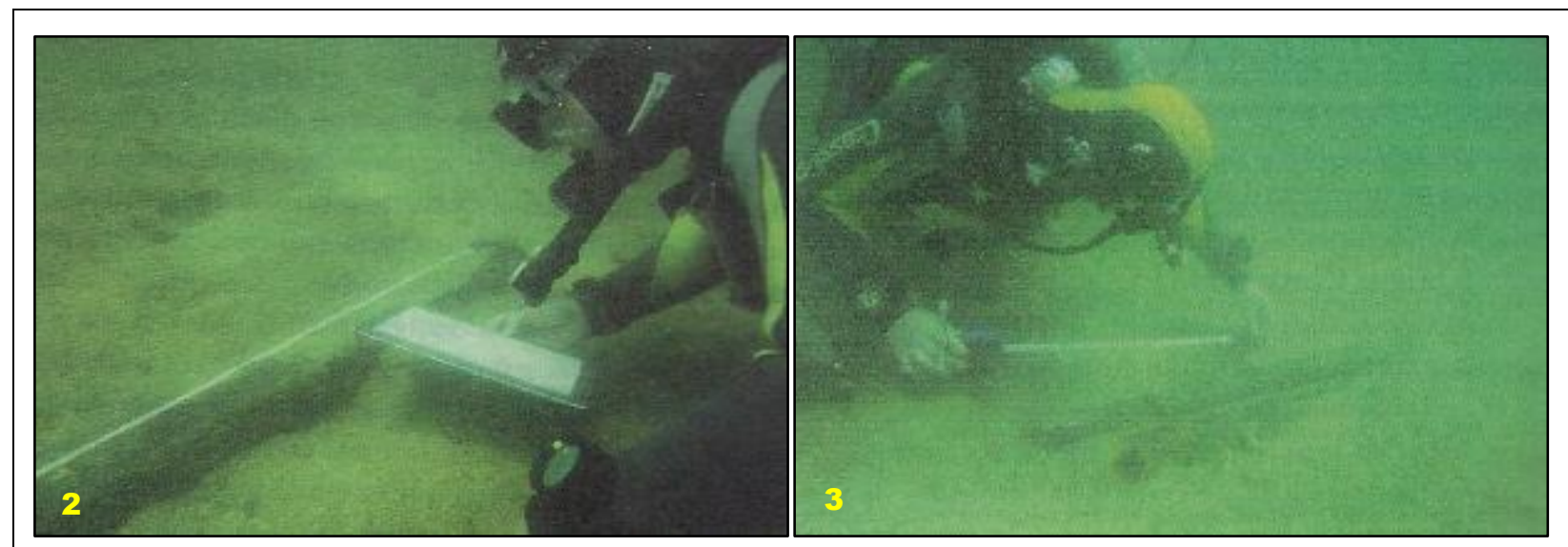

Imagem 2 e 3. Pesquisas subaquáticas realizadas na Baía de Angra dos Reis que objetivaram encontrar os destroços do Camargo (Fonte: Gilson Rambelli, extraídas de RAMBELLI, 201320).

\section{Bergatim Trouvadore ${ }^{21}$}

O Trouvadore era um navio negreiro espanhol que naufragou em 1841, próximo as ilhas Turcas e Caicos, no mar do Caribe, quando realizava uma viagem com carregamento de africanos que seriam comercializados como escravos em Cuba. Acredita-se que estivesse carregando entre 280 e 300 africanos, mas, quando a embarcação começou a naufragar, tanto os 20 membros da tripulação quanto, os 193 africanos que estavam a bordo sobreviveram. Isto sugere que cerca de 100 africanos haviam morrido durante a travessia do Atlântico.

Foram realizadas três etapas de campo, até que os destroços pudessem ser anunciados como pertencentes ao Trouvadore. Em 2004, a equipe localizou um naufrágio de madeira e, na etapa de 2006, foi realizada uma primeira escavação, no entanto, nenhum material de diagnóstico foi encontrado. Somente na etapa de 2008, a terceira temporada de campo, com a cooperação de uma expedição multidisciplinar dos Estados Unidos - NOAA (National Oceanic and Atmospheric Administration), que os destroços foram confirmados como sendo o Trouvadore. O escritório de exploração oceânica e pesquisa da NOAA financiou vários anos de pesquisa arqueológica e os trabalhos foram coordenados por Don Keith e Toni Carrell.

\footnotetext{
20 RAMBELLI, Gilson. A vida social entre o céu e o mar: navios negreiros enquanto artefatos da escravidão. Pp 199-219. 2013. In. AGOSTINI, Camilla. Objetos da Escravidão: abordagens sobre a cultura material da escravidão e seu legado. 7 Letras, Rio de Janeiro. 2013b.

21 Informações a respeito das etapas de campo que objetivaram a identificação do naufrágio do Trouvadore podem ser obtidas no slaveshiptrouvadore.org/. Acessado em 4 de novembro de 2016.
} 


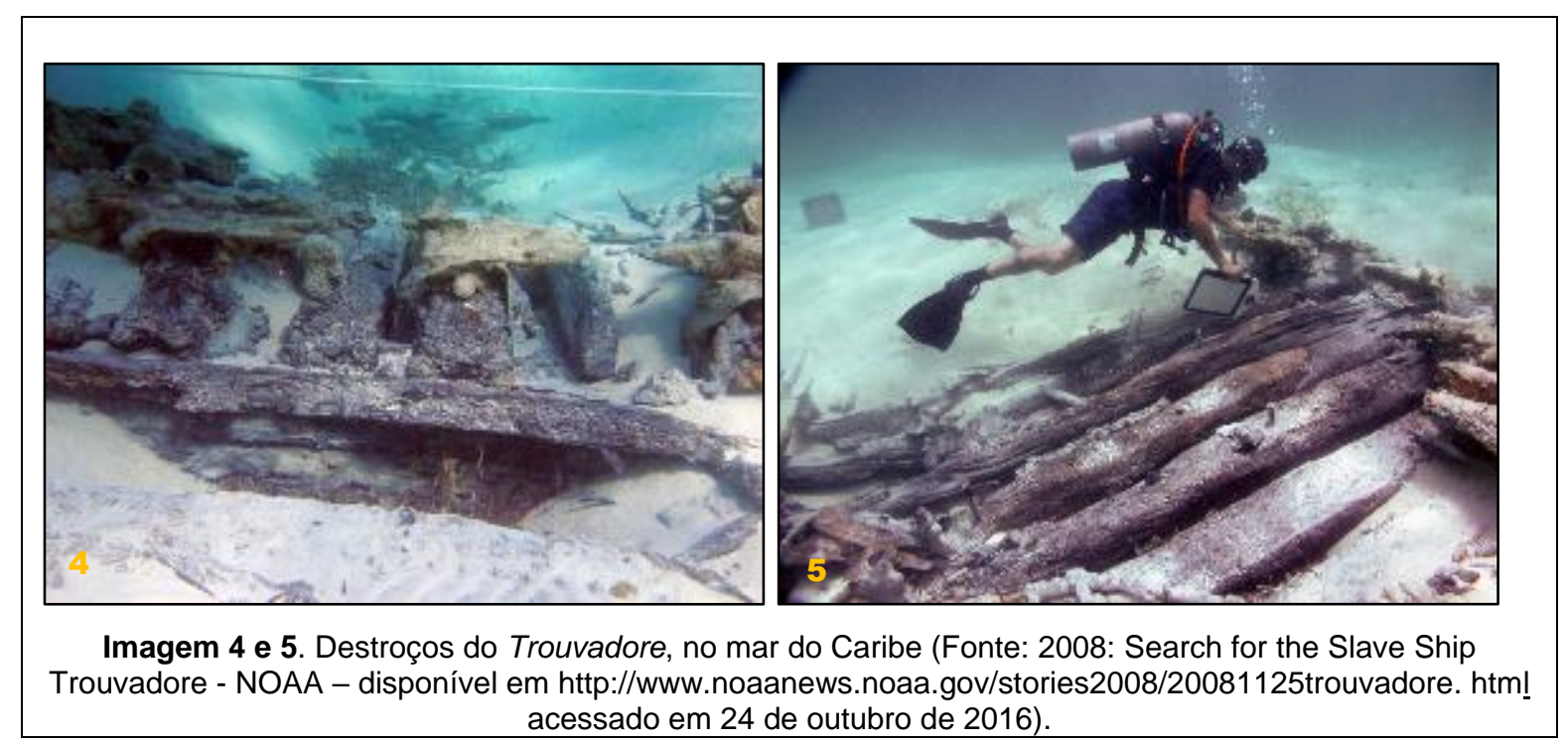

\section{Brigue Henrietta Marie}

Henrietta Marie In memory and recognition of the courage, pain and suffering

Of the enslaved African people. "Speak her name speak her name And gently touch the souls Of our ancestors."

(Placa comemorativa no sítio do naufrágio do negreiro Henrietta Marie).

Naufragado na costa da Flórida ao largo de Key West em 1700/1701, depois de descarregar em torno de 190 africanos na Jamaica, os destroços do tumbeiro Henrietta Marie foram identificados em 1972 e tiveram as pesquisas inicialmente financiadas pela Mel Fisher, uma das maiores empresas de caça ao tesouro dos Estados Unidos. No entanto, a Mel Fisher estava em busca de navios espanhóis, notadamente o lendário galeão Nossa Senhora de Atocha. Mas, com a descoberta do Henrietta Marie, acabaram financiando os primeiros anos de pesquisa. $O$ sino da embarcação foi encontrado e consolidou-se como o artefato que ratificou a identificação dos vestígios (TINNIE, S/D). De acordo com Silva e Fraccaro (2009), o trabalho de escavação na embarcação "surgiu como um projeto impactante e com forte memória social". 
O jornalista americano Michael Cottman ${ }^{22}$, se envolveu nos primeiros anos de pesquisa histórica sobre o Henrietta Marie e pode acompanhar uma equipe de historiadores e arqueólogos, além de fazer uma longa pesquisa e de participar de uma série de mergulhos em busca do tumbeiro. Com o envolvimento de outros pesquisadores na década de 1980, os trabalhos nos destroços continuaram, principalmente no casco de madeira. No entanto, de acordo com Rambelli (2006a:105) o trabalho realizado no Henrietta Marie na década de 1980, "serviu mais como um marco ilustrativo da história do que um trabalho de interpretação arqueológica".

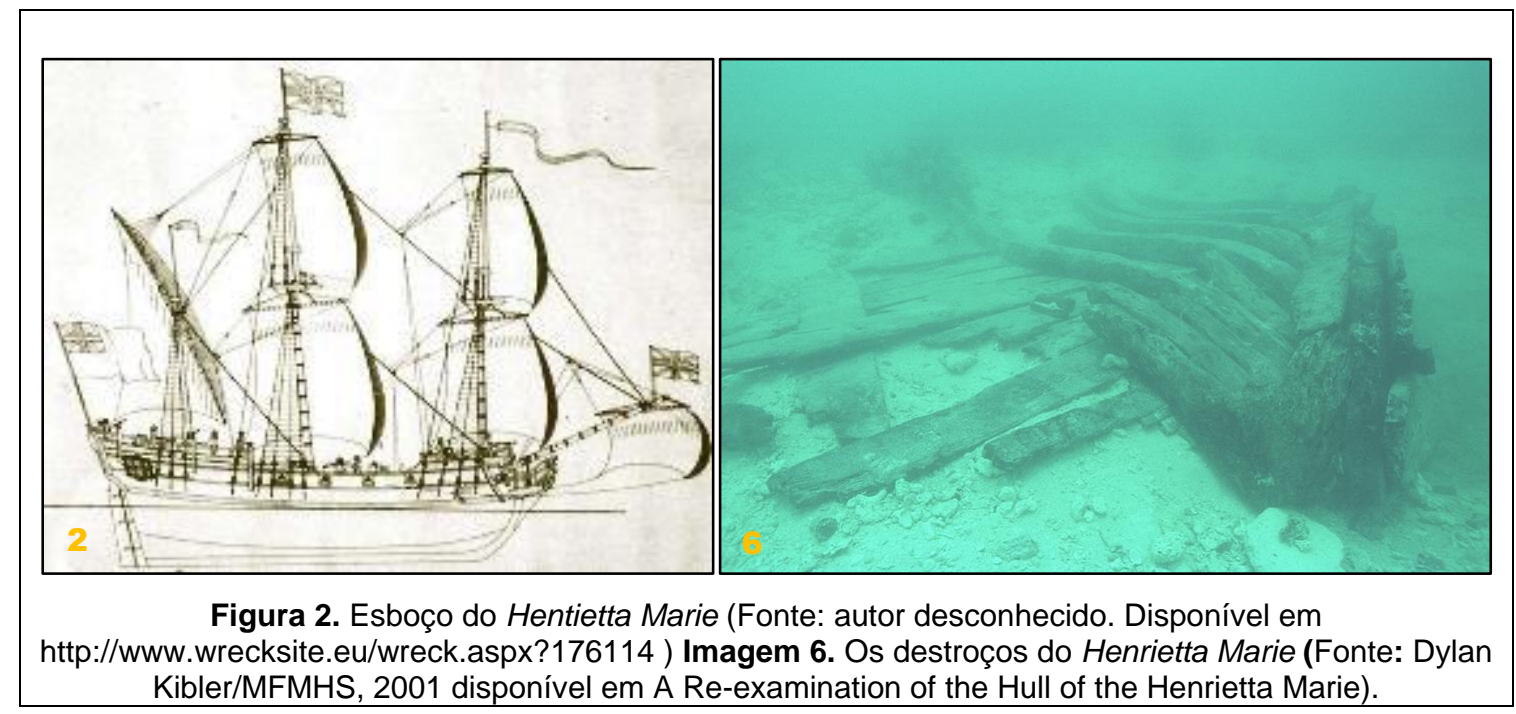

\section{Veleiro São José Paquete África}

Os destroços do São José Paquete África foram encontrados no Cabo da Boa Esperança, na costa da África do Sul, praticamente em frente a Cidade do Cabo. Segundo levantamentos realizados pelos pesquisadores, a embarcação naufragou com aproximadamente 500 africanos a bordo. Ela havia partido de Moçambique no dia 3 de dezembro de 1794, rumo ao Maranhão, na região norte do Brasil, onde os africanos escravizados seriam vendidos para trabalhar nos engenhos de açúcar. Acredita-se que a embarcação tenha naufragado após 24 dias de viagem, devido a uma mudança brusca nas condições meteorológicas, tendo sido acometido por uma

\footnotetext{
22 Michael Cottman, fazia parte de um grupo de mergulhadores negros e publicou um livro de memórias e reflexões (COTTMAN, Michael. H. The Wreck of the Henrietta Marie. New York, Crown, 1999), suas e de diversos indivíduos que se envolveram no projeto, negros e não negros. A obra é o resultado de uma sensibilidade despertada no autor pela participação na pesquisa e mergulho no sítio de naufrágio do Henrietta Marie, e mescla vínculos histórico-culturais, pertença social e realização pessoal (SILVA e FRACCARO, 2009:131).
} 
tempestade. O navio tentou se aproximar da costa sul-africana para fugir de fortes ventos em alto mar, mas se chocou contra pedras e ficou preso entre os rochedos. A operação de resgate foi rapidamente iniciada, sendo que toda a tripulação e grande parte dos africanos escravizados sobreviveram, mas, devido a piora nas condições do tempo, o resgate foi interrompido e a embarcação terminou naufragando com mais de 200 africanos a bordo.

Os destroços do São José foram descobertos em 1980, mas só entre 2010 e 2011 pesquisadores localizaram em Lisboa documentos que permitiram identificá-lo.

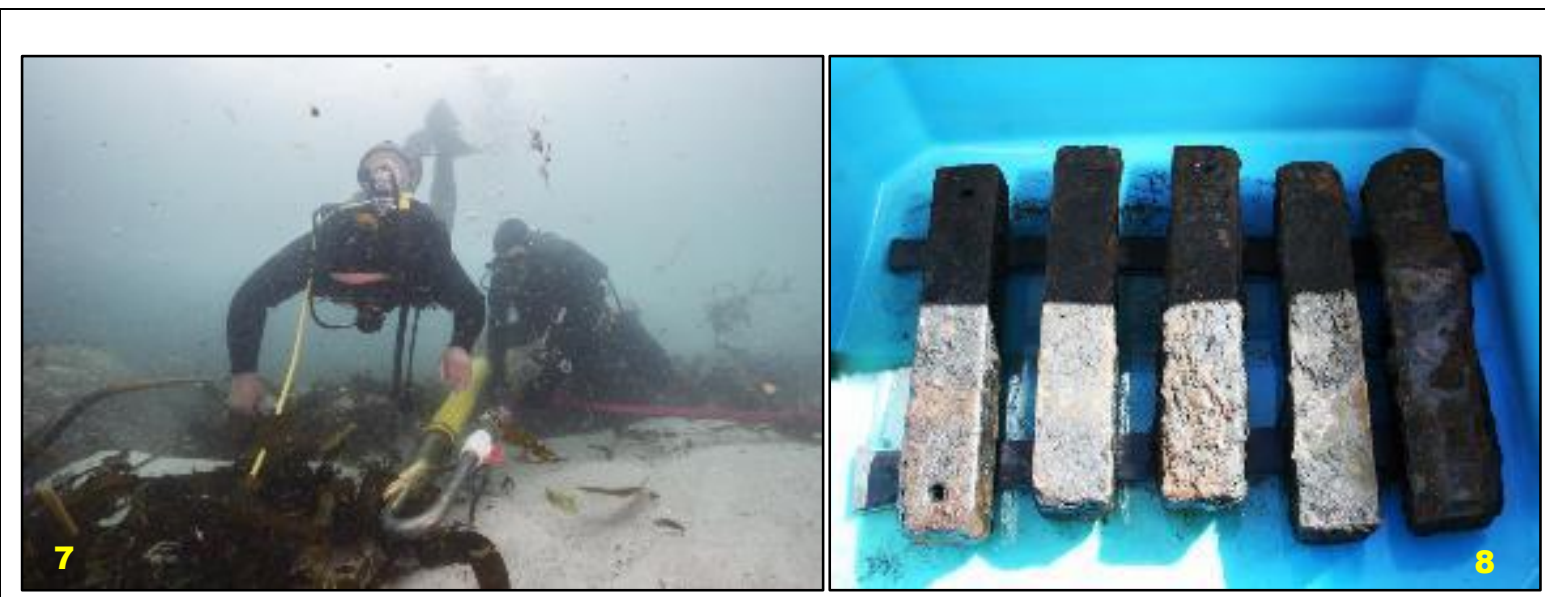

Imagem 7. Mergulhadores na área dos destroços do São José Paquete África e, Imagem 8. Barras de ferro encontradas no naufrágio (Fonte: Disponível em https://www.publico.pt/culturaipsilon/noticia/arqueologosdescobrem-destrocos-de-navio-negreiro-portugues-na-africa-do-sul-1697688 acessado em 23 de outubro de 2016).

A Imagem acima, mostra pesquisas as arqueológicas nos destroços e algumas barras de ferro que foram identificadas utilizadas como lastro e localizadas junto ao casco da embarcação e, de acordo com Gomes,

\footnotetext{
Essas barras eram comuns nos navios negreiros, para manter a estabilidade das embarcações, até porque o peso da carga humana variava nas longas travessias transatlânticas. Nem todos sobreviviam à viagem; as barras serviam para contrabalançar essa variação. Foi a descoberta de barras de ferro no naufrágio que levou os arqueólogos a determinar que o navio transportava escravos (GOMES, 2015, grifo meu).
}

Atualmente, alguns artefatos recuperados nas escavações estão em exposição, graças a um acordo entre arqueólogos marinhos sul-africanos e o Smithsonian, as peças puderam ir Washington e hoje ajudam a compor uma "sala que simula o porão de um navio negreiro, entre lastros de ferro do São José e algemas usadas em outras embarcações" (FELLET, 2016). 


\section{Brigue James Matthews (antigo Don Francisco)}

O James Matthews era inicialmente um navio negreiro que durante o período do tráfico operava sob o nome de Dom Francisco e pertencia a um traficante de escravos chamado Francisco Félix de Souza. Após ser apreendido em 25 de abril 1837, o brigue Don Francisco foi reparado e recebeu o nome de James Matthews, passando a operar na marinha mercante. Os destroços do James Matthews foram localizados em 1973 no lado norte da Woodman Point, em Cockburn Sound, por membros do Underwater Explorers Club (UEC), que estavam fazendo atividades como parte da pesquisa de um curso de naufrágio.

Sob a direção arqueológica de Graeme Henderson, do Museu Marítimo da Austrália Ocidental, arqueólogos e voluntários realizaram pesquisas nos destroços da embarcação em quatro etapas de campo, que aconteceram entre 1974 e 1976. O casco e grande parte da carga transportada ainda puderam ser pesquisadas, devido as boas condições de preservação. Toda a estrutura restante do casco foi escavada e todos os artefatos soltos que estavam dentro da estrutura do casco foram retirados, conservados e alguns estão em exposição nas galerias do naufrágio do WA Maritime Museum, em Fremantle, na Austrália.
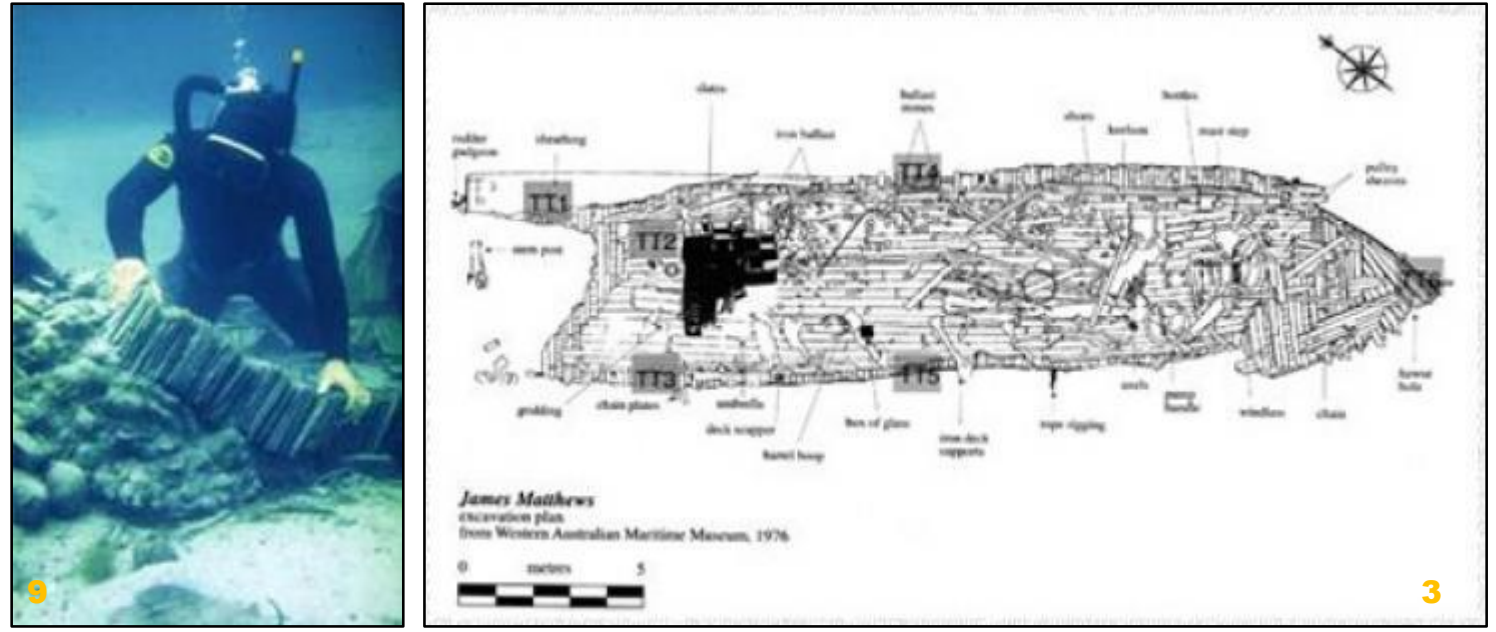

Imagem 9. Pesquisas subaquáticas realizadas nos destroços do James Matthews; Figura 3. Croqui dos destroços do James Matthews (Disponíveis em http://museum.wa.gov.au/research/research-areas/maritimearchaeology/treasures-from-the-deep/james-matthews acesso em 13 de junho de 2015). 


\section{Capítulo 2. \\ DIÁSPORA AFRICANA, TRÁFICO NEGREIRO E ESCRAVIDÃO ADENTRAM AO TERRENO DA ARQUEOLOGIA BRASILEIRA}


Os processos históricos relacionados ao que se convenciona denominar como diáspora africana, tráfico negreiro e escravidão, entre outros termos, têm sido abordados de forma tímida na Arqueologia Brasileira, desde a década de 1930, alcançando maior expressão na década de 1980. Essa circunstância pode ser explicada pelo fato da Arqueologia, sempre inserida em um contexto social e político, ter vivenciado a partir dessa época questionamentos teóricos (Arqueologia Pósprocessual) no âmbito internacional e, em escala nacional, ter se beneficiado da expansão desses estudos nas ciências humanas e sociais, da abertura do regime democrático e do próprio movimento negro. 


\subsection{As pesquisas sobre a Arqueologia da Diáspora no Brasil}

Embora a expressão e a autodenominação como "remanescentes de quilombo" seja teoricamente recente, o quilombo há muito tempo faz parte do imaginário político nacional. Gomes (1992) observa que a militância negra apropria-se do quilombo como representação política de luta contra a discriminação racial e para a valorização da cultura negra. Uma figura importante no meio acadêmico que buscou discutir a presença do negro na sociedade brasileira foi Roger Bastide (1898-1974), que chegou ao Brasil em 1938 como integrante da Missão Francesa - convidada a participar da organização da Faculdade de Filosofia, Ciências e Letras da Universidade de São Paulo. Nessa instituição, Bastide permaneceu por 16 anos e dedicou-se à formação acadêmica dos sociólogos brasileiros (QUEIRÓZ, 1975). Desde seu envolvimento com o curso de Sociologia, demostrou suas preocupações quanto à identidade e à formação étnica ou racial da nação ( $\mathrm{NUCCl}, 2013)$. Outros intelectuais da época também envolveram-se nesse movimento no início do século XX e, segundo Gomes (1994), as primeiras discussões foram fundamentais para o desenvolvimento da questão, pois são

(...) nos estudos afro-brasileiros dos anos 1930 que surgem as primeiras abordagens centradas na formação dos mocambos na sociedade escravista do Brasil. Em parte, baseando-se nas obras pioneiras de Nina Rodrigues ${ }^{23}$, alguns autores, com particular destaque para Artur Ramos, Edison Carneiro e, posteriormente, Roger Bastide, lançam mão de explicações pautadas em interpretações culturalistas para examinar os quilombos no Brasil. Para estes autores - afora algumas pequenas diferenças de argumentação num ou noutro -, a questão essencial para o entendimento dos mocambos brasileiros era o caráter de "contra-aculturação" (GOMES, 1994:29).

Posteriormente às questões levantadas por Roger Bastide, intelectuais como Florestam Fernandes, Ciro Cardoso, Jacob Gorender, Adbias do Nascimento engajaram-se nesse movimento que objetivava inserir a contribuição do negro na sociedade brasileira. Menção também deve ser feita a Clóvis Moura que refletiu principalmente sobre a questão do negro na formação da nação. De acordo com Mesquita (2004), Clóvis Moura

\footnotetext{
${ }^{23}$ Mesmo em âmbito acadêmico, pretensamente tolerante e democrático, estudiosos do "problema negro", como Nina Rodrigues, não se furtavam, nas primeiras décadas do século XX, a expor uma visão preconceituosa, atribuindo aos negros e à miscigenação a dificuldade para o desenvolvimento do Brasil e pregando, como solução lógica de suas teorias racistas, o embranquecimento da população (GOMES, 1994).
} 
pesquisava história, em particular sobre a rebeldia negra no tempo da escravidão, tendo como objetivo demonstrar o importante e ativo papel do negro na formação da nação, não só do ponto de vista cultural, muito abordado naquele momento, mas - e principalmente - social, se desdobrando para os planos político e econômico (MESQUITA, 2004:340).

Apesar do legado da escravidão ser ainda indigesto para sociedades exescravocratas como a nossa, para os historiadores "a instituição escravidão" é considerada um tema clássico e muitas pesquisas têm sido realizadas, desde aquelas que buscavam a abolição, àquelas que visavam ao africano liberto em uma sociedade escravista, além de tantos outros vieses possíveis de investigação. E esse movimento tem gerado novos dados relativos a esse período da nossa história e, de acordo com Machado (2014),

(...) nos anos mais recentes, a sociedade brasileira, na figura de estudiosos da história, da cultura afro-brasileira e militantes dos movimentos negros, tem discutido de maneira mais aberta, em termos históricos, sociológicos e políticos, o legado histórico da escravidão e suas sequelas na sociedade brasileira (MACHADO, 2014:157).

De uma maneira geral, as lutas sociais dos movimentos negros, os debates políticos e debates intelectuais engajados têm como tema central a necessária mudança da sociedade brasileira, objetivando à inclusão e à participação qualitativa e quantitativa do negro.

Nesse sentido, a fim de identificar os primeiros registros que fazem referência a pesquisas arqueológicas no contexto afro-brasileiro, identifiquei em um balanço bibliográfico realizado por Lima (1993) ${ }^{24}$, uma referência a pesquisas arqueológicas realizadas ainda na primeira metade do século XX. Uma dessas pesquisas faz menção a uma escavação realizada no ano de 1930, na cidade de Guaraqueçaba, no estado do Paraná, onde Loureiro Fernandes desenvolveu um trabalho pioneiro nos nichos existentes nos íngremes paredões da Serra Negra em Guaraqueçaba. De acordo com Lima, esses paredões continham

(...) ossadas humanas e vestígios de selos de argila destinados a vedar as aberturas na rocha. Naquele período, os vestígios "foram interpretados como possivelmente pertencentes a negros quilombolas, porém nenhum reduto possível de thes ser atribuído foi encontrado nas proximidades" (LIMA, 1993:225).

\footnotetext{
${ }^{24}$ Que se deteve mais detalhadamente às pesquisas arqueológicas realizadas entre 1960 e 1991.
} 
Apesar da citação acima, não fica claro como os autores chegaram à conclusão de que os vestígios de selo de argila podiam estar associados aos "negros quilombolas". Infelizmente essa informação não pode ser confirmada, pois, de acordo com Lima (1993), a pesquisa não teve continuidade, tendo sido apenas comunicada na época ao arqueólogo Igor Chmyz que a registrou em um levantamento sobre Arqueologia Histórica no estado do Paraná em 1985 (DÉDALO 24:171-97, apud LIMA, 1993).

A partir disso, apresento um panorama das pesquisas em Arqueologia da Diáspora Africana que foram ou estão sendo realizadas especificamente no Brasil. Longe de uma revisão bibliográfica sobre o tema, o presente levantamento não foi feito de forma sistemática e objetiva apenas apresentar ao leitor um pouco dos trabalhos com esse viés e, nesse sentido, procurei trazer pelo menos uma pesquisa em cada estado onde essa temática já foi ou vem sendo abordada. Nesse sentido, a seguir são apresentados os trabalhos selecionados por estado, independentemente de seu escopo.

$\mathrm{Na}$ Amazônia estão em andamento trabalhos relacionados ao contexto da Arqueologia da Diáspora Africana e, como exemplo, cito o projeto de pesquisa coordenado pelo professor Diego Costa intitulado "Arqueologia Histórica dos Africanos na Amazônia" (2015/atual), além de outros textos já publicados (COSTA 2015; 2016). Localizados no estado do Pará e do Amapá respectivamente, Moraes et al (2015) aborda o território étnico dos Povos do Aproaga e do quilombo do Cunani a fim de "estudar e analisar as relações sociais que as comunidades tradicionais quilombolas constroem em torno das paisagens do passado e da cultura material arqueológica encontradas em seus territórios étnicos".

No estado de Pernambuco, conta-se com a dissertação de mestrado de Medeiros (2005), que teve como objeto de estudo a fazenda de São Bento de Jaguaribe, localizada no Município de Abreu e Lima, que objetivou "reconstituir o modelo de organização espacial nas propriedades rurais do tipo fazendas, do período colonial, e apreender as correlações sociais específicas". A mesma fazenda estudada por Medeiros (2005), foi alvo da dissertação de Fabíola Amaral Jansen da Silva (2006), que propôs a reconstituição arqueológica da senzala da fazenda de São Bento 
de Jaguaribe. Não se pode deixar de apontar os trabalhos realizados por Scott Allen, notadamente aqueles relacionados à região serrana dos Quilombos, que abrange além do estado de Pernambuco, o estado de Alagoas. Além do Projeto Arqueológico Monjope, que trata de um antigo engenho que tem sido alvo de escavações desde o ano de 2011.

O quilombo dos Palmares, localizado na Serra da Barriga, no estado de Alagoas, tem sido alvo de diversas pesquisas e tem também fomentado um número considerável de publicações. Desde a primeiras pesquisas iniciadas na década de 1990 por Pedro Paulo Funari e Charles Orser Jr. (ORSER \& FUNARI, 1992; FUNARI, 1996a, 1996b,) que alcançaram notoriedade até fora do Brasil, outros trabalhos foram produzidos. De acordo com Funari (1996a) "o objetivo mais amplo do Projeto Arqueológico Palmares, como foi denominado, consiste em adquirir informação sobre a vida quotidiana em Palmares, principalmente por meio dos vestígios materiais". Precedido por um meticuloso levantamento historiográfico, objetivando entender como os colonizadores "compreenderam e combateram esse Estado rebelde" (Op. Cit.:8) os pesquisadores partiram para a primeira etapa de campo, que consistiu em

(...) um levantamento ou prospecção pedestre, visando localizar vestígios materiais arqueológicos superficiais. Tendo identificado artefatos na superfície, planejamos realizar alguns testes com pás, a fim de determinar a profundidade e grau de preservação do material. Esses procedimentos básicos permitiram mapear os sítios arqueológicos e avaliar as possibilidades de trabalhos arqueológicos futuros mais extensos e demorados (FUNARI, 1996a:8).

O quilombo de Palmares, que foi alvo de pesquisas na década de 1990, continua alimentando discussões e fomentando publicações (ORSER \& FUNARI, 2004; FUNARI \& CARVALHO, 2005a).

No estado de Sergipe, mais precisamente no município de Laranjeiras, Regina Norma de Azevedo Santana (2008) desenvolveu sua pesquisa de mestrado na qual abordou a comunidade do Mussuca, caracterizada como remanescentes de quilombo, utilizando a Arqueologia como ferramenta para a construção de versões alternativas que podem ajudar a compreender a trajetória dos grupos que reivindicam seu reconhecimento.

A dissertação de mestrado de Tavares (2006) analisou as contas de colares e as práticas religiosas de origem africana a partir de sepultamentos encontrados no 
sítio arqueológico da antiga igreja da Sé, em Salvador, estado da Bahia. Além desse trabalho, a tese de doutoramento de Gordenstein, defendida em Salvador em 2014, apresenta a "análise e interpretação dos objetos e espaços usados por um culto afrobrasileiro no centro histórico de Salvador entre o último quartel do século XIX e a década de 1920" (GORDENSTEIN, 2014). O trabalho traz contribuições importantes e introduz o contexto social e o ambiente físico do bairro, que, segundo o autor, possui alguns locais reuniam condições minimamente propícias para a implantação de um culto de influência africana.

Camilla Agostini (1998) já no final da década de 1990 publica um trabalho onde busca identificar marcas da resistência escrava em materiais arqueológicos, notadamente cachimbos, oriundos de sítios históricos no estado do Rio de Janeiro. Ainda no estado do Rio de Janeiro, mais precisamente no município de Angra dos Reis, Gilson Rambelli (2006a, 2006b) abordou em seu pós-doutoramento um navio negreiro que foi afundado propositalmente no início da segunda metade do século XIX. As pesquisas desenvolvidas envolveram levantamentos subaquáticos que objetivavam localizar os destroços da embarcação, mas, apesar dos esforços empreendidos, as evidências localizadas não puderam ser associadas ao naufrágio. No entanto, essa pesquisa inseriu a temática da Arqueologia de naufrágios de navios negreiros no "hall" de possibilidades de abordagens arqueológicas no Brasil. As escavações realizadas em uma fazenda jesuítica pertencente a um Colégio em Campos dos Goytacazes (RJ), que esteve ativa entre os séculos XVII, XVIII e XIX, objetivou analisar o cotidiano da escravidão, regimes demográficos além das práticas culturais (SYMANSKI \& GOMES, 2012). Dentro de um projeto que visava à revitalização da região central do Rio de Janeiro, pode-se destacar as escavações arqueológicas que resultaram na localização do Cais do Valongo e da Imperatriz, importantes marcos da chegada dos africanos escravizados ao Brasil, além de localizar outras importantes evidências, entre elas o Cemitério dos Pretos Novos, que guardava os restos mortais dos povos trazidos do continente africano; a Pedra do Sal, considerado ponto de resistência, celebração e encontro; entre outras áreas apontadas como espaços associados a escravidão no Rio de Janeiro (LIMA, SENE e SOUZA, 2016). O trabalho de Tavares (2012), buscou uma delimitação espacial para fins de proteção legal do Cemitério dos pretos novos, sendo que esse local era "utilizado pelo antigo mercado de escravos do Valongo e recolhia os corpos dos 
cativos que faleciam ao chegar, durante o período de quarentena no lazareto ou de exposição no mercado" (TAVARES, 2012:40).

No estado de São Paulo, Wagner Bornal defendeu seu mestrado no Museu de Arqueologia e Etnologia da Universidade de São Paulo e apresentou os resultados das pesquisas realizadas no sítio arqueológico São Francisco, antiga fazenda escravista localizada no município de São Sebastião, estado de São Paulo (BORNAL, 1995). Esse sítio ainda seria alvo de outro estudo desenvolvido pelo próprio Bornal (2008), agora sob a ótica da Arqueologia da Paisagem, e resultou em sua tese de doutorado. Em 2011, Camilla Agostini defende sua tese de doutoramento na Universidade Federal Fluminense, onde se dedicou ao estudo das dinâmicas materiais e simbólicas do sítio arqueológico São Francisco que havia sido alvo de trabalhos anteriormente desenvolvidos (BORNAL 1995, 2008). No ano de 2012, dois trabalhos que abordam comunidades quilombolas foram defendidos no MAE/USP, primeiro o de Almeida (2012), que traz uma abordagem etnoarqueológica no território quilombola dos Mandira, no Baixo Vale do Ribeira, município de Cananéia. O segundo trabalho é de Silvia Correa Marques (2012), que aborda um estudo arqueológico do Jaó, uma comunidade localizada na cidade de Itapeva.

Praticamente no mesmo ano em que as pesquisas sobre o Quilombo dos Palmares começaram a surgir, foi defendida na PUC/RS a dissertação de mestrado de Osvaldo Paulino da Silva (1996), que estudou os engenhos da parte Sul da llha de Santa Catarina e buscou a recriação dos sistemas produtivos dos engenhos, por meio do resgate da sua cultura material e da revisão da documentação escrita. Em 2013, Fernanda Mara Borba realizou em seu mestrado um estudo arqueológico pioneiro sobre a escravidão nas fazendas oitocentistas de São Francisco do Sul, em Santa Catarina. Para tanto, a autora se baseou na análise de três antigas propriedades agrícolas localizadas na parte continental do município (Distrito do Saí) e "de uma coleção arqueológica, documentos oficiais, jornais, mapas, fotografias e depoimentos orais" (BORBA, 2013: resumo).

Trabalhos vinculados ao projeto de pesquisa: O Pampa Negro: Arqueologia da Escravidão na região meridional do Rio Grande do Sul (1780-1888), coordenado pelo prof. Dr. Lúcio Menezes Ferreira, da Universidade Federal de Pelotas, vêm sendo apresentados em congressos e encontros pelo Brasil. Um desses trabalho é o de 
Anjos \& Ferreira (2011), que busca elucidar como se deu a formação do campo de Arqueologia da Escravidão no município de Pelotas. Além desse, pode-se citar o trabalho de Rocha et al (2012), que inicia discussões sobre a análise espacial de estruturas arqueológicas referente ao período da escravidão (1780-1888) por meio do mapeamento dessas evidências visando a alimentação de um SIG. Pode-se apontar, ainda, a tese de doutorado de Neli Machado (2004), que aborda os cachimbos e as cerâmicas identificados em sítios arqueológicos do século XIX, no município de São Martinho da Serra, Rio Grande do Sul. A tese de Claudio Carle (2005), que aborda os assentamentos quilombolas no Rio Grande do Sul e contemplou três quilombos: o abrigo Monjolo, em Santo Antônio da Patrulha, do século XVIII, o da Ilha do Quilombo, em Porto Alegre, no início do século XIX e o do Paredão, do final do século XIX em Taquara - e descreveu cerâmicas artesanais e louças localizadas nesses sítios, analisando os possíveis critérios de seleção desses locais com base em referenciais cosmológicos africanos, relacionados, sobretudo, com o culto dos orixás de base iorubá. Novas pesquisas vêm sendo divulgadas, dentre as quais pode-se apontar o trabalho da arqueóloga Beatriz Thiesen et al (2011) na charqueada do Carreiros, no município de Rio Grande, estado do Rio Grande do Sul, que, associando História e Arqueologia, busca compreender a relação dessa charqueada com a sociedade riograndina da época. Estudando charqueadas no Rio Grande do Sul, Estefânia Jaékel da Rosa (2012) buscou, em sua dissertação de mestrado, compreender a dinâmica de funcionamento e a atuação da mão-de-obra escrava na região.

Escavações arqueológicas em engenhos dos séculos XVIII e XIX situados na região da Bacia do Rio Manso, no município de Chapada dos Guimarães, estado do Mato Grosso (SYMANSKI e SOUZA, 2001 apud SYMANSKI, 2007) foram realizadas e revelaram "uma diversidade de contextos, artefatos que somente podem ser entendidos considerando sua participação em práticas relacionadas a sistemas de crenças de origem africana" (SYMANSKI, 2007:10). No ano de 2012 Patrícia Marinho defendeu sua dissertação de mestrado que teve como foco de pesquisa a comunidade do Boqueirão, em Vila Bela da Santíssima Trindade, estado do Mato Grosso e, procurou interpretar processos culturais nessa área remanescente de quilombo, relacionados a elementos da paisagem, em especial às árvores. 
Para o estado de Goiás, os trabalhos desenvolvidos por Marcos André Torres de Souza têm contribuído com avanços na discussão acerca da escravidão no Brasil, tomando como exemplo, o trabalho desenvolvido pelo autor no Engenho de São Joaquim (atual Fazenda Babilônia), um engenho datado de 1800 e que ainda tem sua sede preservada (SOUZA, 2011). O trabalho de Gislaine Tedesco (2009) no Projeto de Resgate Arqueológico nas obras de adequação da Cidade de Goiás, analisou os elementos simbólicos expressos na decoração dos utensílios cerâmicos produzidos pelos africanos escravizados da cidade de Goiás (TEDESCO, 2009). Além de Nóbrega (2014), que discute em sua dissertação de mestrado a possibilidade de, por meio da diversidade da decoração impressa na cerâmica do sítio histórico Maria Mendes, do início do século XIX, "entender as expressões decorativas como forma de representação sociocultural, agenciadas pela(o) oleira(o), o decurso de sua trajetória de vida, da África para o Brasil, dentro do contexto histórico da Província de Goiás" (NÓBREGA, 2014:17).

Para Symanski (2014:182) a Arqueologia da Diáspora Africana inicia suas pesquisas com os estudos de Guimarães e Lanna em cinco quilombos do Vale do Jequitinhonha e da Serra da Canastra, ambos em Minas Gerais. Nesses estudos, os autores se preocuparam em descrever o material arqueológico recuperado, caracterizando-os por fragmentos de cerâmica, cachimbos, panelas de ferro e de esteatita $^{25}$, fragmentos de louças e de garrafas de vidros, entre outros. Carlos Magno (1990) ainda levaria o trabalho desenvolvido no Quilombo do Ambrósio ao I Simpósio Gaúcho sobre a Arqueologia da Escravidão, evento realizado nas dependências da Pontifícia Universidade Católica do Rio Grande do Sul, entre os dias 8 e 12 de outubro de 1990. Mais recentemente, em escavações realizadas no quintal de uma residência do século XVIII, localizada em Diamantina, Minas Gerais, Paiva et al (2015) analisou fragmentos de cachimbos relacionados a africanos escravizados como elementos importantes no entendimento das tramas socioculturais no contexto escravista.

Mas, de acordo com Souza, apesar

\footnotetext{
${ }^{25}$ Esteatita ou esteatite é um mineral filossilicato, com composição química Mg3Si40102. Cristaliza no sistema monoclínico, sendo os cristais muito raros. Apresenta-se geralmente em massas fibrosas ou foliadas. A sua cor varia de branco a cinzento, verde-maçã a amarelada. Apresenta risca branca, brilho perláceo a nacarado e é translúcido a opaco. É uma de baixa dureza e o peso específico varia entre 2,7 a 2,8. Disponível em http://dicionarioportugues.org/pt/esteatite acessado em 6 de setembro de 2016.
} 
(...) do potencial da arqueologia para a compreensão de práticas sociais associadas a grupos que não puderam registrar sua própria história, ainda existem muitas lacunas a ser preenchidas. Esse é o caso da vida escrava, que vem sendo pesquisada por um número ainda muito limitado de arqueólogos, a despeito do imenso peso demográfico e social que teve a escravidão no Brasil (SOUZA, 2011:84).

Além dos trabalhos citados, vários artigos completos publicados em periódicos, capítulos de livros, trabalhos completos e resumos publicados em anais de congressos tem trazido à baila importantes aspectos sobre a Arqueologia da Diáspora Africana em território nacional.

\subsection{De uma Arqueologia dos Quilombos a uma Arqueologia com as Comunidades Quilombolas ${ }^{26}$}

De acordo com Reis e Gomes (1996a:9), "onde houve escravidão houve resistência", por isso, os africanos escravizados tentaram fugir das mais diversas formas: constituíram quilombos, organizaram insurreições, revoltas e foram sujeitos de múltiplas experiências de resistência cotidiana, visando a transformar e reorganizar o mundo em que viviam (REIS \& GOMES, 1996a).

Machado (2014) acrescenta que outras formas de resistência têm sido consideradas nos estudos sobre a escravidão, tais como pequenos furtos, desvios da produção agrícola, trabalhos mal feitos ou inacabados, o culto religioso, além das fugas, das insurreições e das formações dos quilombos. Reis e Gomes (1996a) ainda apontam o fato de o africano fazer "corpo mole" para o trabalho, quebrar ferramentas, atear fogo a plantações, agredir feitores e senhores e as próprias rebeliões individuais ou em grupos representavam sua resistência ao sistema.

No entanto, a ênfase é dada aos quilombos, onde a resistência foi mais manifesta e específica e onde já foram realizadas pesquisas de cunho arqueológico (FERREIRA, 2009b). Os quilombos foram - por sua organização e continuidade histórica - a maior expressão de resistência à escravidão no Brasil.

\footnotetext{
${ }^{26}$ As comunidades quilombolas aqui citadas se referem aos grupos descendentes de africanos escravizados que passam a ser reconhecidas legalmente após a Constituição de 1988.
} 
Nesse interim, busquei nos textos historiográficos a origem da palavra quilombo e, segundo Kabengele Munanga, é uma palavra de origem bantu, do umbundo kilombo, que indica uma instituição política e militar que envolveu várias regiões da África bantu (MUNANGA, 1995/1996:58). A definição bantu tem origem nos estudos promovidos por linguistas europeus e "hoje designa uma área geográfica contígua e um complexo cultural específico dentro da África Negra", sendo que os primeiros contingentes de negros escravizados trazidos para o continente americano eram oriundos de povos dessa região, em virtude das relações estabelecidas entre o reino de Portugal e o reino do Congo. Para Munanga, a presença dos negros bantus e sua liderança nos quilombos são inegáveis, porém, seu caráter seria transcultural, já que reunia negros de outras regiões africanas e demais indivíduos marginalizados pelo regime colonialista (MUNANGA, 1995/1996:58).

Nesse sentido, o termo quilombo, associado a local de resistência e inicialmente definido como "toda habitação de negros fugidos, que passem de cinco, em parte despovoada, ainda que não tenha ranchos levantados e nem achem pilões nele" (ALMEIDA, 1998:12) sofreu significativas transformações conceituais a partir do século $\mathrm{XX}$, principalmente associadas aos estudos antropológicos realizados nas comunidades remanescentes de quilombos, ou comunidades quilombolas.

Pesquisas nas áreas da História e da Antropologia (GOMES, 1992 e 1997; SCHMITT et al, 2002; MATTOS, 2005; TRECCANI, 2006; MATTOS \& ABREU, 2011; GOMES \& MACHADO, 2011) têm trazido grandes contribuições às discussões conceituais sobre os quilombos, gerando novas interpretações que procuraram abranger de maneira mais ampla os mecanismos envolvidos nesse "lugar de resistência", também conhecido como palenques, cumbes, mocambos, mambises, marrons ou ladeiras (GOMES, 1995).

Ramos destaca que

(...) a atenção dos historiadores tem-se geralmente voltado para os grandes quilombos, como o de Palmares e o do Ambrósio. Mas igualmente significativas para a compreensão do passado escravista foram as centenas, os milhares de pequenos quilombos, que pontilharam o interior do Brasil no século XVIII (RAMOS, 1996:187).

Vale ressaltar que os dois quilombos apontados por Ramos (1996) foram alvo de estudos arqueológicos, sendo o quilombo do Ambrósio escavado no final da 
década de 1970 (GUIMARÃES e LANNA, 1980; GUIMARÃES, 1990) e o quilombo de Palmares na metade da década de 1990 (FUNARI, 1996b, 1996c, 1996d). Esses dois quilombos foram importantes, pois foi após esses estudos que as pesquisas arqueológicas relacionadas a diáspora africana começaram a ganhar força. No entanto, quilombos menores acabaram tempo baixa (ou quase nenhuma) visibilidade para as pesquisas arqueológicas.

A pesquisa de Carlos Magnos Guimarães é considerada a primeira no âmbito da Arqueologia da Diáspora Africana no Brasil. Os trabalhos desenvolvidos em Palmares por Funari, com a colaboração do pesquisador norte-americano Charles Orser e do africanista britânico Michael Rowlands, proporcionaram visibilidade internacional às pesquisas desenvolvidas no Quilombo de Palmares. De acordo com Orser, as pesquisas em quilombos ou em

(...) assentamentos escravos fornecem um campo fértil para a investigação arqueológica da expressão material da sobrevivência cultural e criação da comunidade por homens e mulheres que eram forçados a viver em um ambiente estranho entre indivíduos com quem eles poderiam não "se reconhecer" na linhagem, tradição, ou linguagem familiar (ORSER \& FUNARI, 2004:15).

Como já apontado anteriormente, Carle (2005) contemplou, em sua tese de doutorado, três quilombos no Rio Grande do Sul: o quilombo do abrigo do Monjolo (século XVIII), em Santo Antônio da Patrulha; o quilombo da Ilha do Quilombo (início do século XIX) em Porto Alegre e o quilombo do Paredão (final do século XIX), localizado entre os municípios de Taquara e Gravataí.

Muitos desses lugares de resistência continuaram ativos depois da abolição da escravidão em fins do século XIX. Após a promulgação da Lei Áurea, os quilombos que não eram formados apenas por africanos escravizados fugidos, mas também por negros forros, libertos, segregados - continuaram a existir e a resistir.

A Constituição brasileira de 1988 reconhece o direito à terra aos remanescentes das comunidades de quilombo e, de acordo com Abreu et al (2011), a partir da promulgação da Constituição por meio de seu artigo $68^{27}$, o estado deveria emitir os títulos definitivos das terras a essas comunidades. Lentamente, o conteúdo do artigo

\footnotetext{
27 "Ato das Disposições Constitucionais Transitórias. Art. 68. Aos remanescentes das comunidades dos quilombos que estejam ocupando suas terras é reconhecida a propriedade definitiva, devendo o Estado emitir-lhes os títulos respectivos" (CONSTITUIÇÃO FEDERAL, 1988:189).
} 
citado foi sendo difundido e resultou, em alguns casos, na formação de associações de indivíduos que se reconheciam como descendentes das comunidades dos antigos quilombos. Tal situação, já a partir de final dos anos 1990, proporcionou o crescimento do movimento quilombola 28 , o que acabou provocando mudanças nos campos antropológicos e jurídicos, promovendo alterações conceituais onde precisaram ser revistas as interpretações que consideravam a ressemantização da palavra quilombo para efeitos da aplicação da provisão constitucional, valorizando o contexto de resistência cultural que permitiu a viabilização histórica de tais comunidades (FARIA, 2011).

O processo de ressemantização do conceito de quilombo vem de encontro às inúmeras problemáticas que envolveram esse tema nas últimas décadas. Tal situação vem modificando, pelo menos conceitualmente, a inserção do termo quilombo. Atualmente algumas áreas tiveram que voltar sua atenção ao tema, pois ele está deixando de ter um significado apenas vinculado ao passado escravista e passa a ter um sentido sociocultural (NASCIMENTO, 2013). Com isso,

(...) a tarefa de fundamentar teoricamente a atribuição de uma identidade quilombola a um grupo e, por extensão, garantir ainda que formalmente - 0 seu acesso à terra trouxe à tona a necessidade de redimensionar o próprio conceito de quilombo, a fim de abarcar a gama variada de situações de ocupação de terras por grupos negros e ultrapassar o binômio fugaresistência, instaurado no pensamento corrente quando se trata de caracterizar estas conformações sociais (SCHMITT et al, 2002:1).

De acordo com Paula, (2002) a definição de quilombo proposta pela Associação Brasileira de Antropologia em 1994 traz o seguinte texto:

(...) toda comunidade negra rural que agrupe descendentes de escravos vivendo da cultura de subsistência e onde as manifestações culturais têm forte vínculo com o passado, o que, em outras palavras, significa dizer: as comunidades que atualmente reivindicam sua condição de remanescentes de quilombos devem ter em sua composição pessoas que se reconheçam enquanto descendestes de escravos, e não que se reconheçam somente como descendentes de escravos fugidos (PAULA, 2002:6-7).

Até hoje, a inadequação da definição clássica de quilombo está pautada no binômio fuga/resistência e reside no congelamento da existência dos quilombos num tempo passado, no qual atuava a escravidão. Nesse período, os assentamentos

\footnotetext{
28 "O movimento de luta pela garantia dos direitos quilombolas é histórico e político. Traz em seu íntimo uma dimensão secular de resistência, na qual homens e mulheres negros buscavam o quilombo como possibilidade de se manterem física, social e culturalmente, em contraponto à lógica colonial e pós-colonial" (SOUZA, 2008:2).
} 
negros eram vistos apenas como focos isolados de resistência ao regime, destituídos de positividade sociocultural e identitária (ANDRADE, 2007; 2008).

Mais do que um local de resistência no período em que vigorava o sistema escravista, atualmente a resistência das comunidades remanescentes de quilombo continua sendo uma condição fundamental e, embora o trabalho destes autores seja importante e legítimo, ele não contempla, contudo, a diversidade das analogias entre os escravizados e a sociedade escravocrata e, nem as diferentes formas pelas quais esses grupos se apropriaram da terra (SCHMITT et al, 2002).

\subsubsection{A Arqueologia e a Etnoarqueologia em Comunidades Quilombolas}

De acordo com Arruti (2006), a chamada "comunidade remanescente de quilombo" ou "comunidade quilombola" é uma categoria social relativamente nova. Representa uma força social proeminente no meio rural brasileiro, atribuindo uma nova interpretação àquilo que era conhecido como comunidades negras rurais ${ }^{29} \mathrm{e}$ terras de preto $^{30}$. E começa a adentrar ao meio urbano, dando novo significado "a um leque variado de situações que vão desde antigas comunidades negras rurais atingidas pela expansão dos perímetros urbanos até bairros no entorno dos terreiros de candomblé" (ARRUTI, 2006).

De acordo com Lima Filho, (2007)

(...) $\circ$ termo remanescente de quilombo indica a situação presente dos segmentos negros em diferentes regiões e contextos e é utilizado para designar um legado, uma herança cultural e material que the confere uma referência presencial no sentimento de ser e pertencer a um lugar específico. Este sentimento de pertença a um grupo e a uma terra é uma forma de expressão da identidade étnica e da territorialidade, construídas sempre em relação aos outros grupos com os quais os quilombolas se confrontam e se relacionam (..) (LIMA FILHO, 2007:6).

Segundo Almeida (2012), "ainda são incipientes as pesquisas etnoarqueológicas em comunidades auto definidas e reconhecidas como remanescentes quilombolas no Brasil”. Por isso, muitas vezes o pesquisador esbarra na escassez de referências sobre determinada comunidade e, na maioria dos casos, os laudos antropológicos

\footnotetext{
${ }^{29}$ Segundo o autor, essa denominação se dava para as comunidades localizadas mais ao centro, Sul e Sudeste do país.

${ }^{30}$ De acordo com o autor, essa denominação se dava para as comunidades localizadas mais ao Norte e Nordeste.
} 
elaborados a partir dos processos para reconhecimento das comunidades, são os únicos documentos disponíveis. Tal fato evidencia-se nas palavras de Fiabani quando indica que "acontece que para o reconhecimento de uma comunidade como remanescente de quilombo há a necessidade de um laudo antropológico. Muitas das obras citadas são laudos das referidas comunidades" (FIABANI, 2005:8).

Importante indicar que as comunidades formadas por remanescentes de comunidade de quilombos são definidas como grupos étnico-raciais, segundo critérios de auto atribuição, com trajetória histórica própria, dotados de relações territoriais específicas e com ancestralidade negra relacionada com a resistência à opressão histórica sofrida ${ }^{31}$.

Ainda, de acordo com Schmitt,

os grupos que hoje são considerados remanescentes de comunidades de quilombos se constituíram a partir de uma grande diversidade de processos, que incluem as fugas com ocupação de terras livres e geralmente isoladas, mas também as heranças, doações, recebimento de terras como pagamento de serviços prestados ao Estado, a simples permanência nas terras que ocupavam e cultivavam no interior das grandes propriedades, bem como a compra de terras, tanto durante a vigência do sistema escravocrata quanto após a sua extinção (SCHMITT et al, 2002:3).

Mesmo com a inserção do artigo 68 nas disposições transitórias da Constituição Federal de 1988, a maior parte das comunidades remanescentes de quilombos permanece sem o devido reconhecimento oficial. Outro instrumento legal foi criado para viabilizar a titulação definitiva a terra, o Decreto $\mathrm{n}^{\circ} 4887 / 03^{32}$, no entanto, esses instrumentos ainda não surtiram o efeito necessário.

Contudo, esses grupos passaram a ser designados como comunidades autônomas de negros e foram constituídas a partir de múltiplos processos que não se limitaram apenas à história de "escravos rebeldes e fugidos", como também não necessariamente estavam isolados e distantes dos grandes centros urbanos. Segundo dados da Fundação Cultural Palmares (FCP), do Instituto Nacional de Colonização e Reforma Agrária (INCRA) e de outros órgãos e instituições, estima-se

\footnotetext{
31 Definição adaptada do Decreto ํㅜ 4.887, de 20 de novembro de 2003.

32 Decreto no 4887 de 20 de novembro de 2003. Regulamenta o procedimento para identificação, reconhecimento, delimitação, demarcação e titulação das terras ocupadas por remanescentes das comunidades dos quilombos de que trata 0 art. 68 do Ato das Disposições Constitucionais Transitórias. Disponível em http://www.planalto.gov.br/ccivil 03/decreto/2003/d4887.htm acessado em 4 de julho de 2015.
} 
que existam hoje no Brasil aproximadamente 5.000 comunidades quilombolas auto reconhecidas, destas, aproximadamente 193 tiveram seu processo de titulação finalizado (YABETA \& GOMES, 2013).

$\mathrm{Na}$ área alvo dessa pesquisa, apesar de publicado em 1988, o artigo 68 da Constituição Brasileira só chegou ao conhecimento dos remanescentes das comunidades quilombolas de Ubatuba depois do ano 2000. Até essa data, as comunidades lutavam pelas terras como podiam e, segundo Branco (2007), permaneciam na invisibilidade,

(...) suportando excessos de autoridades judiciais, de especuladores, dos órgãos e instituições governamentais por se tratar de uma comunidade negra com pouco ou quase nenhum acesso às leis que regem a sociedade" (BRANCO, 2007:65).

A Arqueologia tem contribuído, ainda que de maneira tímida, para o conhecimento e reconhecimento da quilombagem ${ }^{33}$, seja nas pesquisas sistemáticas desenvolvidas em sítios arqueológicos como o quilombo do Ambrósio, dos Palmares, seja em remanescentes de comunidades quilombolas que procuram seu reconhecimento (CARVALHO \& CAVALHEIRO, 2007:588).

Camilla Agostini indica, em publicação de 2009, que o estudo da cultura material deixada pelos africanos escravizados "(...) apresenta uma dificuldade singular, pela natureza fragmentária dos indícios, sejam os materiais, documentais, iconográficos, orais, como é de se esperar (...)" (AGOSTINI, 2009:39), se referindo a grupos em posição subalterna em uma determinada sociedade. Nesse sentido, o estabelecimento de diálogos com as comunidades quilombolas, é extremamente importante e permite uma diversificação das vozes interpretativas sobre o passado, e possibilita que o coadjuvante possa ser o protagonista (AGOSTINI, 2009). Dessa forma, busca-se o fortalecimento da herança cultural das comunidades, em especial, na valorização de sua diversidade (AGOSTINI, 2009).

Nesse sentido, alguns estudos etnoarqueológicos foram realizados em comunidades quilombolas. Regina Norma de Azevedo Santana (2008), que desenvolveu em seu mestrado uma pesquisa onde apresenta o território negro da

\footnotetext{
${ }^{33}$ De acordo com Moura, a quilombagem "é um movimento histórico e social que, no Brasil, teve início no final do século XVI (...). Caracterizou-se pela formação contínua de grupos de negros rebeldes e fugitivos, que constituíam comunidades próprias, os quilombos. A quilombagem perdurou durante todo o tempo em que existiu a escravidão no Brasil e foi um elemento de desgaste permanente do sistema escravista (MOURA, 2013:334).
} 
Mussuca, localizado em Laranjeiras, estado de Sergipe, e utiliza a Arqueologia como ferramenta para a construção de versões alternativas que podem ajudar a compreender a trajetória dos grupos que reivindicam seu reconhecimento.

A dissertação de mestrado de Carvalho (2012), já mencionada, realizada com Comunidade Boqueirão em Vila Bela, no estado do Mato Grosso, objetivou dar maior importância às questões relacionada a cultura material e imaterial, que remetessem ao universo negro no Brasil e, segundo a autora, "consideradas pela Arqueologia Histórica mesmo assim pouco explorada no campo da religiosidade, no qual, até pouco tempo atrás, se apresentava descontextualizada" (CARVALHO, 2012:30).

Para o estado de São Paulo, segundo dados obtidos na Fundação Cultural Palmares, até o momento, foram certificadas 46 comunidades quilombolas (FCP, 2016). No entanto, no levantamento realizado, foram identificados apenas dois trabalhos, ambos defendidos em 2012. O primeiro é o de Almeida (2012), que traz um estudo etnoarqueológico no território quilombola dos Mandira, no Baixo Vale do Ribeira, no município de Cananéia. O autor, buscou entender "o modo de apropriação dos elementos e marcos da paisagem, incluindo os vestígios arqueológicos, que constituem o conjunto de lugares de resistência formador desta paisagem" (ALMEIDA, 2012: ix). O segundo trabalho é de Silvia Correa Marques (2012), que aborda um estudo arqueológico do Jaó, localizado na cidade de Itapeva, e a autora buscou identificar "através da Arqueologia da Paisagem e do cotejamento com as fontes históricas, cartoriais e orais, outros caminhos interpretativos para a paisagem quilombola". 


\section{CAPítulo 3.}

\section{O PALCO DA PESQUISA: O LITORAL NORTE}

PAULISTA. 
A região conhecida atualmente como litoral Norte paulista é composta pelos municípios de Caraguatatuba, São Sebastião e Ubatuba e pelo arquipélago de Ilhabela (Mapa 1).

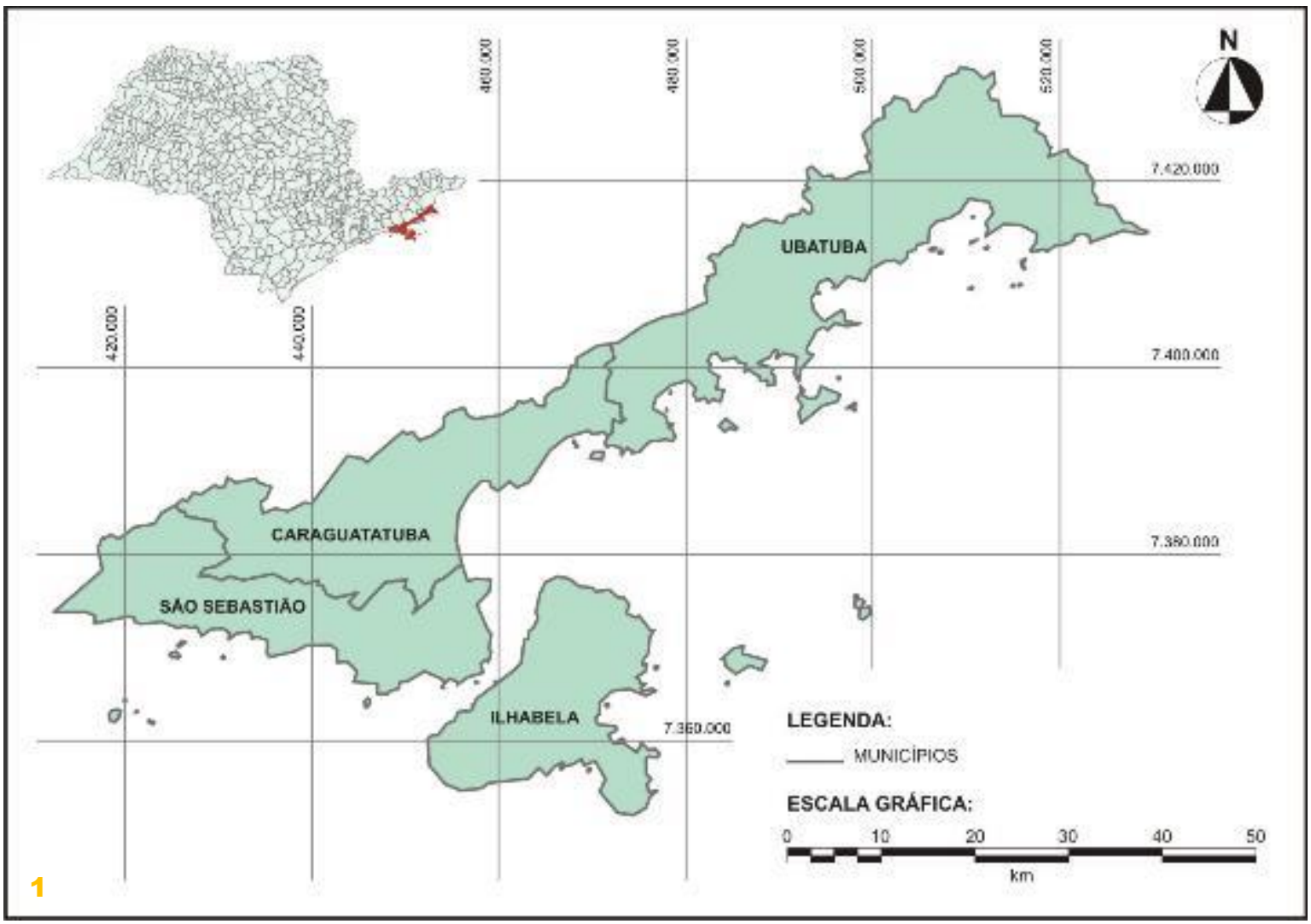

Mapa 1. Litoral Norte de São Paulo

Conforme exposto anteriormente, a escolha dessa região não foi aleatória e está ligada principalmente à sua posição estratégica no contexto da economia cafeeira que se instalou no século XIX no Vale do Paraíba. Outras regiões na costa brasileira constituíram importantes portos de chegada de africanos durante mais de 300 anos em que esse comércio foi permitido. A demanda por mão-de-obra nos engenhos de açúcar e aguardente fez de Pernambuco um local com grande movimentação de embarcações carregadas de africanos a fim de abastecer as lavouras canavieiras. A Bahia também recebeu grande contingente de africanos durante longo período, principalmente a cidade de Salvador que, até segunda metade do século XVII, era a capital da colônia portuguesa. A mudança da capital para a cidade do Rio de Janeiro em 1763 ocasionou uma diminuição na chegada de africanos na Bahia e, consequentemente, provocou um aumento no Rio de Janeiro. Ainda assim, a 
necessidade por mão-de-obra para a realização dos serviços fazia com que os desembarques acontecessem em praticamente toda a costa brasileira.

Mesmo durante o período em que o comércio negreiro era considerado legal, buscava-se desembarcar o mais próximo possível do local de destino dos africanos e, por isso, alguns desembarques também aconteciam fora dos portos convencionais (RODRIGUES, 2000), situação que foi sensivelmente intensificada com as primeiras proibições do comércio negreiro em 1831. Com isso, o litoral Norte paulista se insere no cenário escravista principalmente pela sua localização geográfica privilegiada em relação ao Vale do Paraíba.

\subsection{Primeiras aproximações ${ }^{34}$ : características ambientais, aspectos socioeconômicos e manifestações culturais}

\subsubsection{Características ambientais}

Localizado em porção contígua ao vale do rio Paraíba do sul e também ao eixo industrial entre Rio de Janeiro e São Paulo, o litoral Norte paulista se impõe como um

(...) espaço linear, bordejado pelo oceano Atlântico e a Serra do mar. A Mata Atlântica que cobre suas encostas possui uma das maiores biodiversidades do planeta e seus remanescentes florestais abrigam a maioria das espécies animais ameaçadas de extinção (ERCARNAÇÃO, 2010:70).

Porções dos municípios de Ubatuba, São Sebastião e Caraguatatuba estão inseridos dentro do Parque Estadual Serra do Mar (PESM), que foi instituído em 1977 e representa a maior porção contínua preservada de Mata Atlântica no Brasil. Em uma área de 332 mil hectares, sua extensão abarca 25 municípios paulistas, localizados desde a divisa do estado com o Rio de Janeiro até o litoral sul de São Paulo ${ }^{35}$ (PLANO DE MANEJO DA SERRA DO MAR, 2006).

\footnotetext{
34 Nesse item, serão abordados, de maneira genérica, aspectos relacionados as características ambientais, socioeconômicas e culturais do litoral Norte paulista como um todo e depois de forma sintética para cada município que compõe a região em apreço.

35 "No final da década de 1970, grandes vitórias foram alcançadas com a criação dos Parques Estaduais de Ilhabela, da Serra do Mar e da Ilha Anchieta. O tombamento da Serra do Mar pelo Conselho de Defesa do Patrimônio Histórico, Artístico, Arqueológico e Turístico do Estado de São Paulo (CONDEPHAAT) em 1985 inseriu o componente paisagístico e cultural nos processos de proteção em maior escala, que resultaram na criação da Reserva da Biosfera da Mata Atlântica (1992) " (PLANO DE MANEJO DA SERRA DO MAR, 2006: 12).
} 
Os municípios do litoral Norte paulista também compõem a Área de Proteção Ambiental Marinha - APA Marinha do Litoral Norte - que foi criada em 8 de outubro de 2008, por meio do decreto 53.525 e tem como finalidade proteger, ordenar, garantir e disciplinar o uso racional dos recursos ambientais da região, inclusive suas águas, por meio do ordenamento das atividades turísticas, de pesquisa e de pesca, de modo a promover o desenvolvimento sustentável (SECRETARIA DO MEIO AMBIENTE, 2016).

De acordo com Silva (1975), o litoral Norte paulista apresenta bordas continentais bastante recortadas, num intervalo que se inicia na baía de Guanabara, no estado do Rio de Janeiro e se estende até a cidade de Santos, já no estado de São Paulo. O autor ainda acena para a grande presença de sítios portuários, contracenando com certa dificuldade de acesso ao planalto em função das escarpas da serra do mar. No entanto, com distâncias que podem chegar a oito ou nove quilômetros entre a escarpa e a linha de costa, os acessos aos municípios no interior acabam sendo realizados por meio de alguns vales encaixados, que proporcionam a circulação de pessoas e de animais.

Em relação aos aspectos geomorfológicos do litoral Sudeste brasileiro, a proximidade da encosta da Serra do Mar em vários pontos chega diretamente ao oceano (MUEHE, 2006:316), dando um aspecto "afogado", recortado e oferecendo pequenas enseadas, além de ilhas e reduzidas planícies costeiras (MUEHE, 2006:317). Nesse sentido, encontra-se praias cujas extensões variam entre poucas centenas de metros até quatro quilômetros, com exceção da planície costeira ${ }^{36}$ de Caraguatatuba que possui, aproximadamente, dez quilômetros de extensão.

Perto de $80 \%$ do território dos municípios do litoral norte é composto por áreas continentais e os $20 \%$ restantes por áreas insulares. Das ilhas que compõe a região, destaco a ilha de São Sebastião, principal ilha do município de Ilhabela, além de outras dezenas de ilhas, ilhotas e lajes com mais de 200 quilômetros de linha de costa, esta significativamente recortada (ROCHA, 2011). Essa região é interceptada pelo trópico de Capricórnio ${ }^{37}$, nos limites da zona tropical, atribuindo condições climáticas

\footnotetext{
36 As planícies costeiras ou litorâneas são planícies formadas por sedimentos terciários ou quaternários, depositados na zona costeira.

37 A linha imaginária do Trópico de Capricórnio passa por Ubatuba, nas coordenadas $23^{\circ} 26^{\prime 2} 29^{\prime \prime}$ Sul e $45^{\circ} 04^{\prime} 34^{\prime \prime}$ Oeste.
} 
específicas. Caracterizada como uma das regiões mais chuvosas do país, em virtude, sobretudo, de uma complexa circulação atmosférica. Essas interações podem ocasionar resultados pluviais diferenciados e o confronto com o sistema tropical Atlântico resulta numa intensa atividade pluviométrica (CAMPOS et al, 2000:23).

Ubatuba fica a 222 quilômetros de São Paulo, tem pouco mais de 87.300 habitantes (IBGE, 2016) e faz divisa no estado de São Paulo com os municípios de Caraguatatuba, Natividade da Serra e São Luís do Paraitinga. Já no estado do Rio de Janeiro, os limites são com Cunha e Paraty. O município possui mais de $80 \%$ de seu território em uma área de conservação ambiental sob administração do Parque Estadual Serra do Mar (PESM). Com uma linha de costa extensa (ROCHA, et al, 2010), o litoral de Ubatuba apresenta mais de 90 praias $^{38}$, além de ilhas, ilhotas, lajes ${ }^{39}$ e as bordas compreendidas pelos costões rochosos ${ }^{40}$ e pela barra dos rios ${ }^{41}$, sendo que na desembocadura de alguns desses rios, ocorre a formação de manguezais.

Por características específicas de sua plataforma continental, além da orientação de suas praias, é possível encontrar ao longo da costa ubatubana praias com variados tipos de ondas. A presença de seis enseadas continentais ${ }^{42}$, distribuídas ao longo do litoral, apresentam configurações particulares, tendo nos arredores algumas unidades geomorfológicas que propiciam um ambiente protegido para a aproximação e atracamento de embarcações. Atualmente, todas essas enseadas, com maior ou menor intensidade, tem populações locais. A enseada de Ubatuba possui maior densidade populacional, pois abarca o núcleo político/administrativo, e é onde, até meados do século XIX, se localizava o porto de Ubatuba. Com largura máxima de

\footnotetext{
38 Importante salientar que esse número abarca as praias continentais e insulares. Em alguns casos, em um mesmo segmento de praia existe uma subdivisão e cada porção recebe um nome, passando um segmento a ter duas ou mais praias, como é o caso da praia do Sapê e praia da Maranduba, localizadas a Sul do núcleo urbano de Ubatuba. Apesar de que do ponto de vista ambiental esses setores se referirem a um único sistema praial, optou-se nesse trabalho por considerar essa subdivisão, por isso o número de praias apresenta-se tão expressivo. ${ }^{39}$ São 16 ilhas, 7 ilhotas e 7 lajes (Ilha Comprida, Ilha das Couves, Ilha da Pesca, Ilha das Palmas, Ilha do Prumirim, Ilha Anchieta, Ilha da Selinha, Ilha da Pedra, Ilha da Ponta, Ilha dos Porcos, Ilha do Mar Virado, Ilha da Maranduba, Ilha Redonda, Ilha Rapada, Ilha do Negro, Ilha Pequena, Ilhota do Sul, Ilhota de Fora, Ilhota de Dentro, Ilhota da Carapuça, Ilhota da Comprida, Ilhota das Couves, Ilhota das Cabras, Laje Mofina, Laje Pequena, Laje Grande, Laje Feia, Laje das Palmas, Laje do Forno e Laje Grande do Perequê).

40 É o nome dado ao ambiente costeiro formado por rochas situado na transição entre os meios terrestre e aquático. Nesse sentido, é considerado muito mais uma extensão do ambiente marinho que do terrestre, uma vez que a maioria dos organismos que o habitam, estão relacionados ao mar (Disponível em http://www.ib.usp.br acessado em 19 de setembro de 2016).

41 Banco de areia ou detritos, submerso ou não, fixo ou móvel, que se forma na foz de um rio onde a corrente fluvial se encontra com o mar (CHERQUES, Sérgio. Dicionário do mar. São Paulo: Globo. 1999. 550 págs.).

42 Enseada de Picinguaba, Enseada de Ubatumirim, Enseada de Ubatuba, Enseada do Flamengo, Enseada da Fortaleza e Enseada do Mar virado. Na ilha Anchieta está a Enseada das Palmas.
} 
cinco quilômetros no sentido norte/sul, com um estreitamento significativo na entrada ficando como uma "boca" de pouco mais de dois quilômetros onde abriga seis praias ${ }^{43}$. Com um litoral significativamente recortado, Ubatuba se destaca dos demais municípios do litoral norte nesse quesito, conforme observa-se no mapa abaixo:

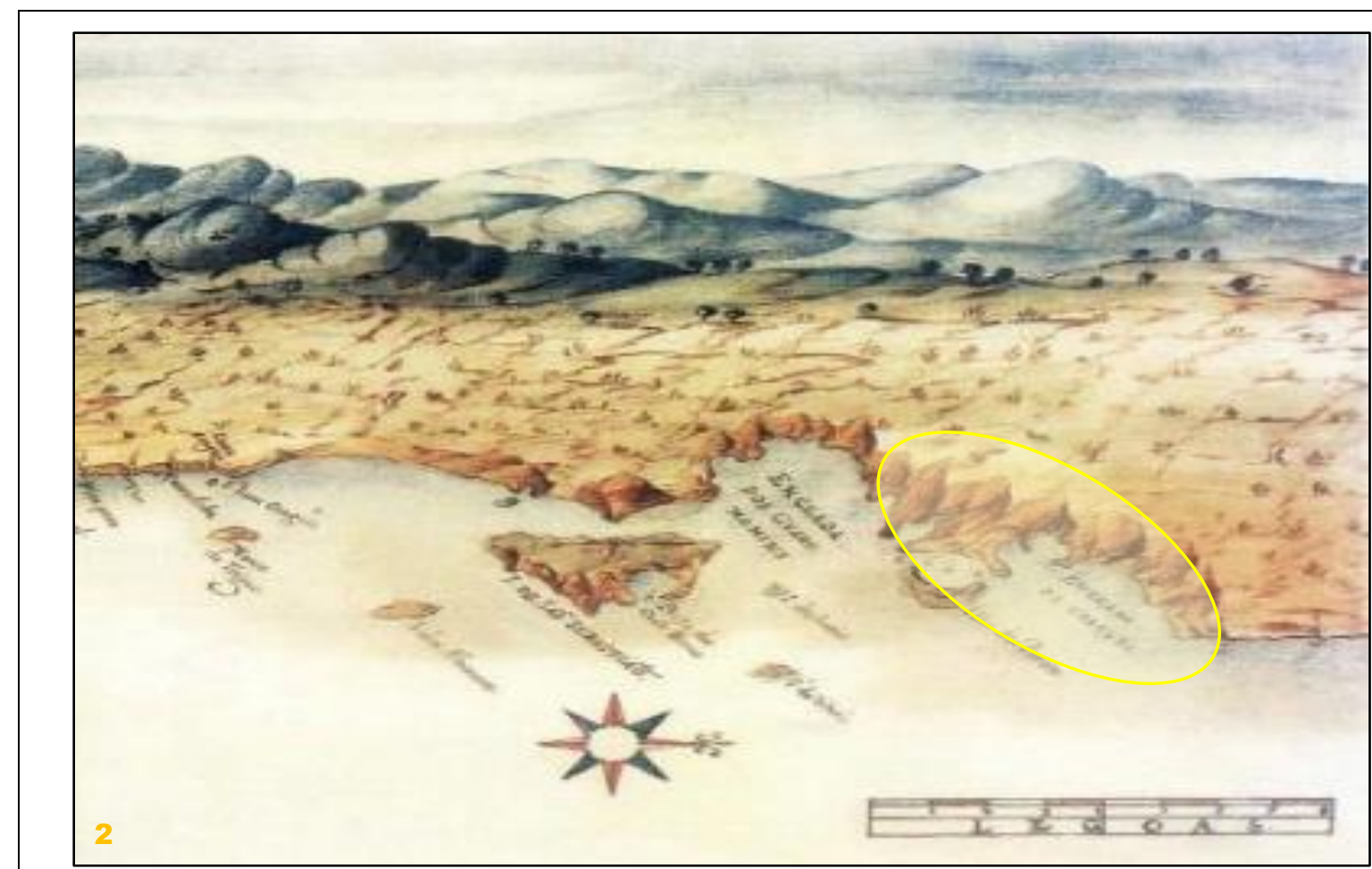

Mapa 2. Manuscrito com aquarela representado a Capitania de Santo Amaro de autoria de João Teixeira Albernaz, datado de 1631 (Fonte: Mapas Históricos Brasileiros - Editora Abril Cultural).

Apesar do mapa acima (mapa 2) exibir outros municípios ${ }^{44}$ além de Ubatuba, ele foi selecionado por exibir a quantidade de reentrâncias atribuída ao litoral ubatubano já no século XVII. A configuração de suas bordas continentais atribui um potencial significativo para a utilização desses locais nos mecanismos envolvidos no desembarque e recepção dos africanos que, clandestinamente, chegavam nessas terras. Nesse sentido, mais adiante, algumas questões relacionadas às características das bordas continentais serão tratadas, juntamente com as praias indicadas na literatura historiográfica e obtidas por meio de informações orais, como pontos de

\footnotetext{
43 No sentido norte-sul: praia Barra Seca, Perequê-Açu, do Padre, Iperoig, Itaguá e Prainha do Cais.

${ }^{44}$ Onde atualmente está localizado o município de Caraguatatuba ainda é possível observar uma grande enseada. Para o local onde hoje se localiza São Sebastião, pode-se observar uma costa mais retilínea, praticamente sem nenhuma reentrância, com exceção de uma a Sul de onde hoje está o núcleo urbano de São Sebastião, que pela espacialização atualmente conhecida, essa reentrância pode se referir a Praia de Toque Toque Grande. Da mesma forma, a ilha de São Sebastião no município de Ilhabela, a Baía de Castelhanos apresenta-se bem marcada na figura.
} 
desembarques clandestinos e que foram alvo de prospecção de superfície nas etapas de campo.

Distante 173 quilômetros de São Paulo, Caraguatatuba tem pouco mais de 115.000 habitantes (IBGE, 2016) e faz divisa ao Norte com Ubatuba, a Noroeste com Natividade da Serra, a Oeste com Paraibuna, a Leste com oceano Atlântico e ao sul com São Sebastião. É nesse município que está a maior extensão de terras planas de todo o litoral Norte paulista, sendo que a planície de Caraguatatuba tem aproximadamente $190 \mathrm{~km}^{2}$ e é recortada pelos rios Juqueriquerê, Claro, Pirrasununga, Camburu e seus afluentes (CAMPOS et al, 2000:17). Com uma faixa litorânea de menor extensão em relação a Ubatuba, o município de Caraguatatuba possui uma grande enseada, localizada a sul ${ }^{45}$ onde está inserida a maior parte da população além de ser a sede política/administrativa do município. Implantada em uma extensa planície, com distâncias que podem chegar a mais de dez quilômetros ${ }^{46}$ até as primeiras escarpas da serra do mar, o relevo bordejante dessa enseada proporcionou o assentamento da maioria da população em áreas planas, no entanto, ocorreram ocupações desordenadas de encostas de morros e de áreas ribeirinhas. Suas águas são consideradas abrigadas ${ }^{47}$, pois a sul sofre influência da porção norte da ilha de São Sebastião, além de que as ilhas de Búzios e a ilha Vitória também colaboram no desvio de algumas correntes, sendo todas essas ilhas pertencentes ao município de Ilhabela. Ao lado da enseada de Caraguatatuba, existe um segmento contínuo que não chega a ser uma enseada, mas abriga cinco praias ${ }^{48}$, além do ilhote da Cocanha e da llha do Tamanduá. Entre os dois segmentos existe uma área plana, limitada a Leste por uma elevação coberta de vegetação onde está a praia de Martin de Sá. Apesar de uma costa mais linear quando comparada a Ubatuba, Caraguatatuba também apresenta uma praia com características "mais abrigadas". A praia de Tabatinga, localizada no extremo norte do município já na divisa com Ubatuba, localizada bem em frente a ilha do Tamanduá. Essa praia, encontra-se mais

\footnotetext{
45 Denominada de Enseada de Caraguatatuba.

${ }^{46}$ As distâncias variam de pouco menos de um quilômetro nas extremidades Norte e Sul a aproximadamente onze quilômetros seguindo o rio Juqueriquerê até as escarpas da serra do mar.

47 Essa enseada abriga a Prainha, a praia do Garcêz ou praia da Freira, praias do Centro e Camaroeiro, praia do Indaiá, praia Pan Brasil ou Aruan, praia das Palmeiras, praia do Romance, praia Porto Novo e praia das Flecheiras (sentido norte-sul).

48 Praia de Tabatinga, praia da Mococa, praia da Cocanha, praia do Massaguaçu e praia de Capricórnio (sentido norte-sul).
} 
protegida, por terra, pelo relevo mais escarpado em seu entorno, caracterizando um "anfiteatro" e atribuindo a esse ponto específico da costa caraguatatubense um abrigo natural, protegido de correntes e ventanias continentais. A praia de Tabatinga está indicada na literatura historiográfica consultada com ponto ilegal de desembarque de africanos escravizados e, por isso, foi alvo de registro na etapa de campo realizada em 2015, sendo os apontamentos preliminares indicados no capítulo 4.

São Sebastião está localizado a 195 quilômetros de São Paulo e tem em torno de 84.000 habitantes (IBGE, 2016). Faz divisa com Salesópolis, Caraguatatuba e Bertioga e está separado de Ilhabela pelo canal de São Sebastião. O canal (imagem 10) é caracterizado por uma passagem marinha com quase 22 quilômetros de comprimento e uma configuração encurvada, com eixo orientado para nordeste na parte Sul e na extremidade oposta para norte. As entradas do canal têm larguras maiores que a parte central, sendo 7,2 quilômetros e 5,6 no norte e sul, respectivamente e 1,9 quilômetros na porção central. A profundidade alcança os 42 metros (média da baixa mar de sizígia, CARTA NÁUTICA 1645), possibilitando com isso a entrada de embarcações de grande calado ${ }^{49}$.

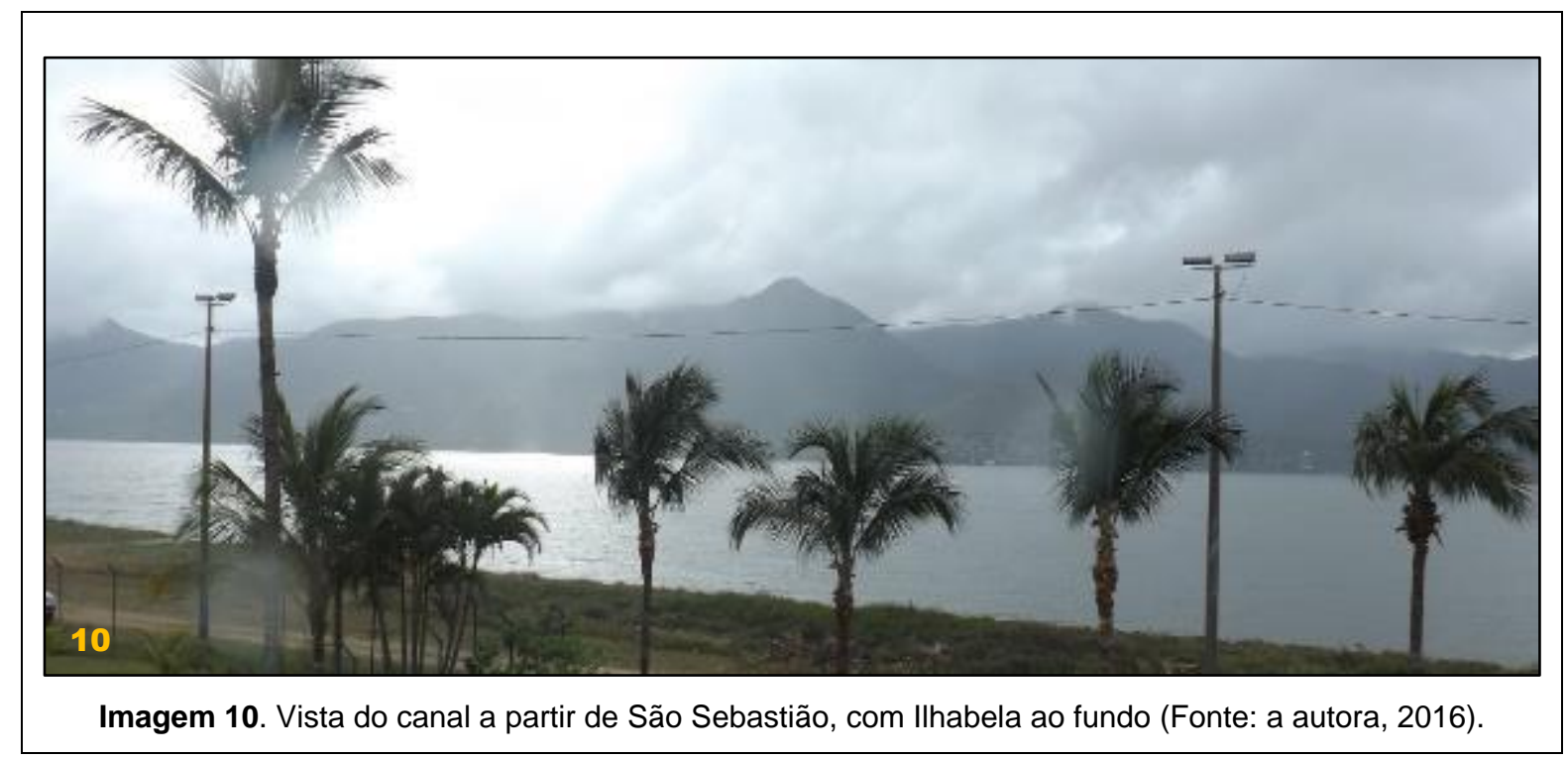

O município ocupa uma faixa de terra estreita, pois de um lado está o oceano Atlântico e do outro as escarpas da Serra do Mar e, de acordo com Bornal, por causa

49 Calado é a distância vertical medida da linha de flutuação a face inferior da quilha de uma embarcação, independente do ponto que se tome. O tamanho do calado das embarcações são informações preciosas que determinam sua entrada ou não em determinados portos. 
das características da "topografia local, as formas de apropriação do espaço trouxeram consequências vividas na atualidade, como a expansão urbana descontrolada" (BORNAL, 2008:1). Com mais de 80 quilômetros de linha de costa, São Sebastião tem belas praias ${ }^{50}$ espalhadas principalmente na porção localizada a Sul do núcleo urbano. O distrito de Maresias está encaixado entre as escarpas da serra do mar, que nessa porção vão desembocar diretamente no oceano, sendo que morfologia semelhante pode ser observada nas praias de Boiçucanga, Paúba, Toque Toque Pequeno, Toque-Toque Grande e Juquehy. As distâncias das praias até as escarpas da Serra do Mar não chegam a quatro quilômetros, como é o caso da praia do Camburi. Como apontado anteriormente, a planície é curta, o que traz implicações para um acesso "direto" ao planalto. A borda continental assume uma formação com algumas reentrâncias em toda a extensão abrangida pelo município, com exceção da praia da Enseada que está na divisa com Caraguatatuba e ainda faz parte da enseada homônima. A partir da praia das Cigarras até a praia da Juréia, São Sebastião vai exibir uma costa irregular, com praias "encaixadas" e barras de rios. Na divisa ao Sul, com Bertioga, uma extensão significativa da praia de Boracéia faz parte do município de São Sebastião. Mais adiante, essa porção da praia juntamente com outros pontos do litoral sebastianense serão retomados como indicativos de possíveis pontos de desembarques clandestinos de africanos no século XIX.

O município de Ilhabela $^{51}$ está localizado em frente ao município de São Sebastião. Fica a 197 quilômetros de São Paulo e, segundo o senso 2016 (IBGE), o município tem pouco mais de 32 mil habitantes e é composto pela ilha de São Sebastião, onde está sediada a base política/administrativa e localizada a grande maioria da população, além da Ilha de Búzios, Ilha da Vitória, Ilha dos Pescadores ${ }^{52}$ e de cinco ilhotes ${ }^{53}$.

\footnotetext{
50 Conforme localização de norte a sul: Praia da Enseada, Cigarras, São Francisco, Olaria, Praia do Arrastão, Pontal da Cruz, Praia Deserta, Porto Grande, Praia Preta, Praia Grande, Pitangueiras, Barequeçaba, Guaecá, Toque Toque Grande, Santiago Calhetas, Toque Toque Pequeno, Paúba, Maresias, Brava, Boiçucanga, Camburi, Camburizinho, Baleia, Barra do Sahy, Conchas, Praia Preta, Juquehy, Barra do Una, Juréia e Boracéia.

51 Importante lembrar que a definição genérica de ilha é de "uma porção de terra cercada de água por todos os lados". A grosso modo, todos os continentes são cercados por terra de todos os lados, mas foi estabelecido um tamanho limite para a caracterização de uma ilha, é nesse sentido o tamanho máximo para uma porção de terra cercada de água ser nomeada de ilha é de 2 milhões de $\mathrm{km}^{2}$ que é o tamanho da Groelândia.

52 De acordo Cintia Bendazzoli, essas três ilhas são habitadas (2014:26).

53 Ilhote das Cabras, Serraria, Castelhanos, Lagoa, Figueira e das Enchovas.
} 


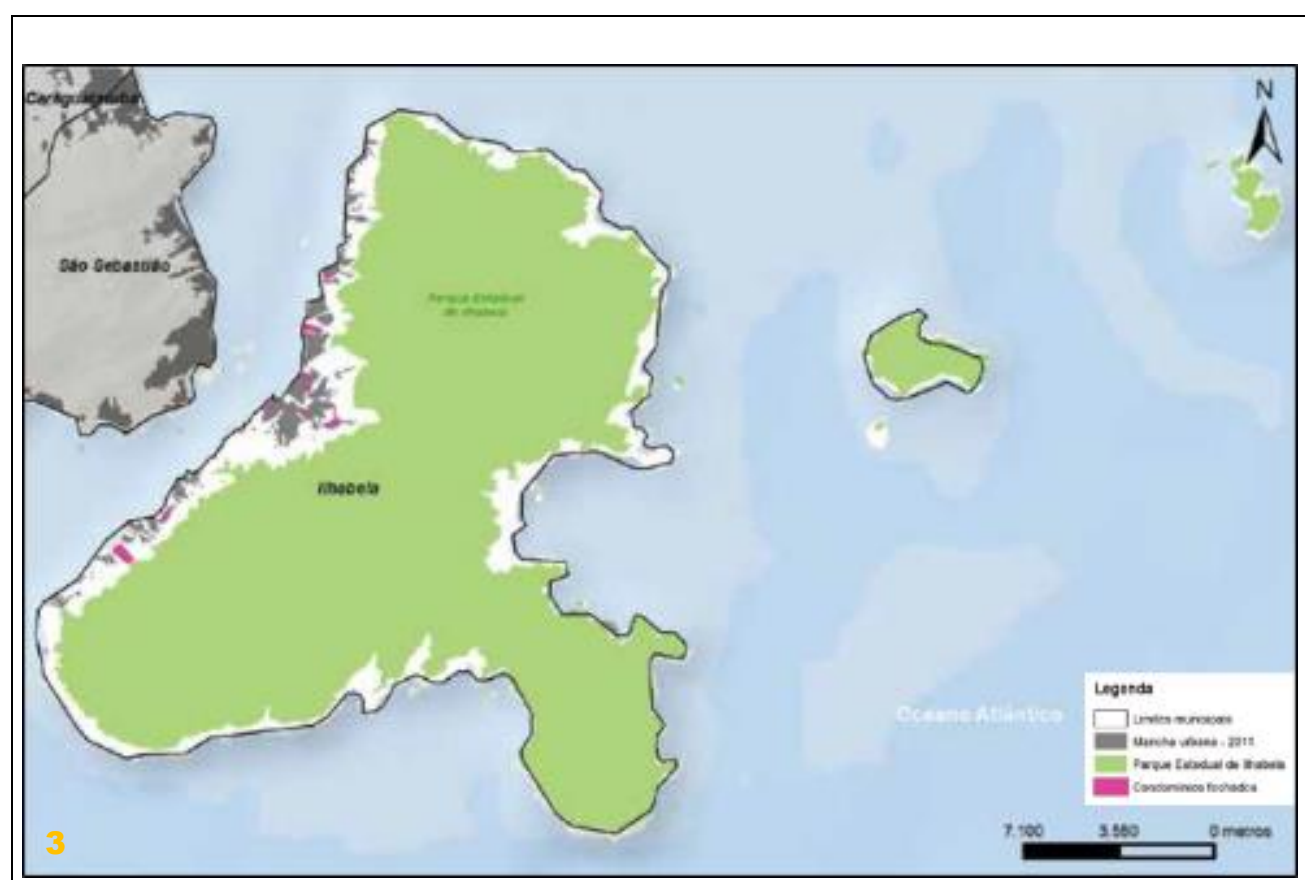

Mapa 3. Abrangência do Parque Estadual de Ilhabela (Fonte: mapa extraído do Resumo Executivo de Ilhabela - Litoral Sustentável).

Grande parte do município é ocupado pelo Parque Estadual de llhabela (PEIB), que foi criado pelo decreto oㅜ 9.414 em de 20 de janeiro de 1977 e é administrado pela Fundação para a Conservação e a Produção Florestal do Estado de São Paulo (Fundação Florestal). Com uma área de 27.025 hectares, configura-se como maior parque insular do Estado de São Paulo. No mapa 3, acima, é possível observar (em verde) a extensão do Parque Estadual de Ilhabela.

Ilhabela possui aproximadamente 36 quilômetros de praias $^{54}$ e mais de 120 quilômetros de costões rochosos. De acordo com Calvente (1993:25) a água potável é abundante, pois as

“(...) planícies são pequenas e para cada uma convergem os muitos ribeirões formados nas montanhas. Graças à ação das massas de ar úmidas provenientes do Atlântico brasileiro, é também uma das áreas mais chuvosas do país, contando com mais de 400 ribeirões, na quase totalidade encachoeirados, de grande beleza cênica" (CALVENTE, 1993:25).

\footnotetext{
54 Distribuídas pelas praias da Armação, praia da Caveira, praia da Figueira, praia da Fome, praia da Garapocaia, pedras do Sino, praia da Guanxuma, praia da Pacuíba, praia da Barra Velha, praia da Feiticeira, praia da Ponta Azeda, praia da Siriúma, praia das Enchovas, praia de Barreiros, praia de Indaiaúba, praia de Itaquanduba, praia de Santa Tereza, praia do Engenho D'água, praia do Oscar, praia do Pinto, praia do Portinho, praia do Saco do Eustáquio, praia Grande, praia Vermelha, praia da Fome, praia da Serraria, praia da Vila, praia das Pedras Miúdas, praia dos Castelhanos, praia de Itaguaçu, praia de Jabaquara, praia de Pequeá, praia do Bonete, praia do Curral, praia do Gato, praia do Julião, praia do Perequê, praia do Poço, praia do Saco da Capela, praia do Veloso, praia do Viana e praia Mansa.
} 
A ilha de São Sebastião apresenta um relevo peculiar, com picos de grandes altitudes ${ }^{55}$, além de inúmeros riachos e cachoeiras e de acordo com Noffs é

(...) um grande maciço montanhoso disposto paralelamente ao canal que a separa do continente. Vista da cidade de São Sebastião, a serra mostra por inteiro sua vertente ocidental, que domina toda a paisagem do canal. $\mathrm{Na}$ vertente oposta da serra, situam-se a Baía dos Castelhanos e a enseada das Enchovas. Nesta face, o litoral é mais recortado e voltado para o mar aberto (NOFFS, 2007:4).

$\mathrm{Na}$ face Leste da ilha de São Sebastião está localizada a baía de Castelhanos, que abriga comunidades caiçaras e algumas praias ${ }^{56}$. A praia dos Castelhanos é a maior em extensão ${ }^{57}$ e a principal desta baía. $O$ acesso a baía de Castelhanos é feito ou por carro tracionado por uma estrada de 22 quilômetros que corta a ilha no sentido Oeste a Leste, ou por barco. Por essas características, essa região é indicada nos textos historiográficos como local de desembarques de africanos escravizados no período de ilegalidade do comércio negreiro e será melhor analisada no capítulo 4.

\subsubsection{Aspectos socioeconômicos}

Os primeiros registros de atividades econômicas na região, de acordo com Campos (et al, 2000:88), datam de meados do século XVII quando as vilas do litoral Norte paulista estavam plantando as lavouras de cana-de-açúcar e com uma produção maior de aguardente em relação ao açúcar (CAMPOS et al, 2000:88). A figura abaixo (figura 4) traz um exemplo de uma moenda de cana movida a tração animal ${ }^{58}$, utilizada para a extração do caldo da cana.

\footnotetext{
55 O ponto mais alto da llha é o Pico de São Sebastião, com 1.375 m de altitude.

56 Praia da Figueira, Praia Mansa, Praia Vermelha, Praia dos Castelhanos e a Praia do Gato.

57 Possui pouco mais de um quilômetro, a Norte fica o canto do Ribeirão e ao Sul o canto da Lagoa, sendo que em cada extremidade existe um riacho que deságua no mar. O riacho do canto do ribeirão tem um caudaloso hídrico mais abundante e o do canto da lagoa necessita de chuva na serra para que suas águas rompam a pequena lagoa que se forma na baixada, antes da crista de areia formada pelas ondas da praia.

58 Nos engenhos ativos no período colonial existiam instalações destinadas ao preparo do açúcar, tais como a moenda - onde se moía a cana para a extração do caldo (a garapa); as fornalhas - onde o caldo de cana era fervido e purificado em tachos de cobre; a casa de purgar - onde o açúcar era branqueado, separando-se o açúcar mascavo (escuro) do açúcar de melhor qualidade e depois posto para secar. Muitos engenhos possuíam também destilarias para produzir a aguardente (cachaça), utilizada como escambo no tráfico de negros da África (Disponível em http://www.multirio.ri.gov.br/historia/modulo01/eng colonial.html acessado em 15 de outubro de 2016).
} 


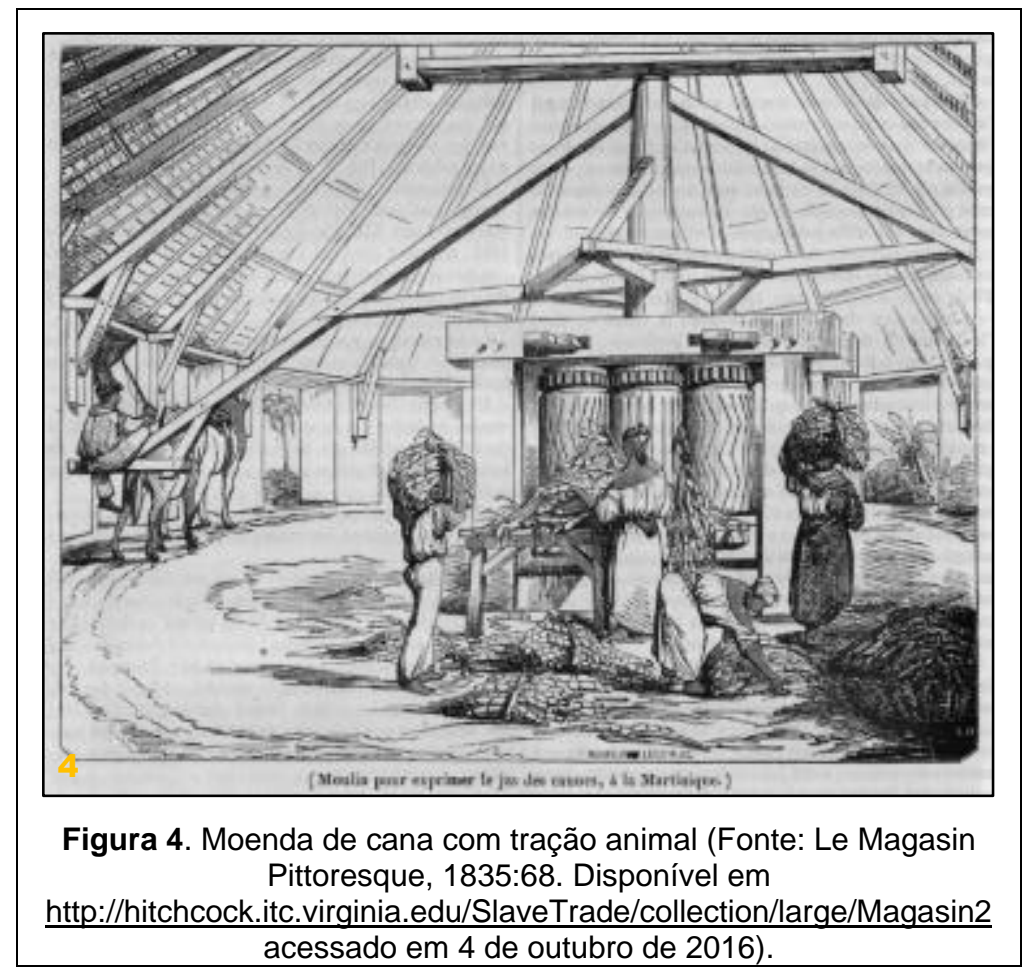

No decorrer do século XVIII, com a expansão da mineração de ouro em Minas Gerais, muitas regiões do Brasil acabaram sofrendo um rápido despovoamento, pois a ilusão da riqueza repentina acabou arrebatando a população dessas vilas. Ainda de acordo com Campos (et al, 2000:89), em Ubatuba, segundo um documento de 1747, a maioria das casas foram abandonadas e a vila de Ubatuba parecia mais uma "aldeia".

Cardoso aponta para o fato de que, ainda que timidamente, no primeiro quartel do século XIX, "o cultivo da cana-de-açúcar e a exportação de seus derivados se consolidaram como principal atividade econômica da região" (2013:76). No entanto, seria somente a partir do segundo quartel do século XIX que o litoral norte conheceria uma fase de maior desenvolvimento econômico por meio do ciclo do café.

São nas palavras de Luna e Klein que o envolvimento dos municípios do norte de São Paulo nesse contexto econômico do século XIX fica mais evidente quando aponta duas ${ }^{59}$ zonas exportadoras em expansão, sendo uma

(...) o Vale do Paraíba, no extremo norte do Estado, fazendo fronteira com o Rio de Janeiro. Esse vale e os portos costeiros setentrionais a ele associados eram, na realidade, uma extensão da economia do Rio de Janeiro. Por isso, as pequenas vilas dessa região foram, em geral, as primeiras a compartilhar

\footnotetext{
59 Segundo o autor, a outra zona em expansão na época era o Oeste Paulista.
} 
as tendências econômicas mais modernas vigentes no Rio de Janeiro, o que, por sua vez, era o centro dinâmico do Brasil: fato que a própria Coroa reconheceu quando mudou a capital da colônia de Salvador para o Rio de Janeiro, em 1763. Nessas localidades do vale e ao longo do litoral, surgiram as primeiras fazendas modernas de açúcar e café movidas pela mão-de-obra de escravos africanos. Portanto, essa parte de São Paulo foi, em certa medida, uma extensão da dinâmica economia do Rio de Janeiro (LUNA \& KLEIN, 2005:17).

É ainda no século XIX que as articulações com o planalto se acentuaram, devido principalmente à abertura dos caminhos que ligavam São Sebastião a Salesópolis, Caraguatatuba a Paraibuna e, Ubatuba a São Luís do Paraitinga (SILVA, 1975; PANIZZA, 2004). O autor ainda acena para o fato de que a "exploração econômica de recursos naturais embalou os primeiros séculos de ocupação humana (PANIZZA, 2004:70).

Segundo Borelli (2012), a prosperidade alcançada pelo litoral Norte paulista durante o ciclo do café seria interrompida na segunda metade do século XIX com

(...) o advento das ferrovias São Paulo - Santos (1867) e São Paulo - Rio (1877), com a mudança do eixo cafeeiro para o Oeste paulista, o que implicou num longo período de isolamento e estagnação para o Litoral Norte - quando, então, a população passou a dedicar-se às atividades extrativas de pequeno porte, à pesca, ao artesanato e à agricultura de subsistência" (BORELLI, 2012: 4).

Conforme citado por Borelli, a implantação das ferrovias acabou por provocar mudanças extremamente significativas que implicaram em prejuízos econômicos aos municípios do litoral Norte paulista. As vias de transporte desempenhavam um papel extremamente importante para a região e, da mesma forma como a implantação de ferrovias desarticulou as relações comerciais, foi a melhorias nas vias de transporte que vão proporcionar um viés desenvolvimentista para a região e segundo Panizza, elas acabam

(...) interferindo sobremaneira no isolamento ou em sua articulação com outras regiões de maior dinamismo econômico. Como uma "região periférica" ela sofreu direta ou indiretamente as flutuações, entre prosperidade ou declínio e isolamento, decorrentes dos ciclos produtivos voltados para 0 mercado externo (PANIZZA, 2004:76). 
Nesse sentido, já no século XX a ampliação do sistema de transporte rodoviário ${ }^{60}$ proporcionou avanços significativos com a abertura da rodovia dos Tamoios ${ }^{61}$ e da rodovia Osvaldo $\mathrm{Cruz}^{62}$, que faziam a interligação do planalto com a baixada. Além disso, margeando o Atlântico na maior parte de sua extensão estava a Rodovia RioSantos $^{63}$, que interligava os municípios litorâneos, permitindo assim que o potencial turístico da região passasse a ser explorado, visto que agora se contava com meios de alcançar os municípios por terra e não mais exclusivamente por mar. A vocação turística do litoral norte veio se acentuando desde então e os municípios vêm colhendo os frutos dessa atividade, que tem aspectos positivos e negativos, como bem observa Encarnação,

(...) o turismo, com atrativos econômicos evidentes, destaca-se como uma manifestação que traz forte impacto para a região, uma vez que leva, entre outros fatores, aumento demográfico sazonal e a ocupação imobiliária, conhecida como residência secundária. Este fato vem transformando essas localidades litorâneas, promovendo a alteração da paisagem e ainda, acarretando graves problemas socioambientais para seus moradores, dentre os quais estão o deslocamento das populações locais, a expansão da urbanização e a descaracterização dos núcleos de comunidades tradicionais (ENCARNAÇÃO, 2010:70).

De uma maneira geral, atualmente, o litoral Norte paulista tem "sua economia marcada pela sazonalidade decorrente da predominância do turismo veranista, que é o seu principal fator de desenvolvimento" (SÃO PAULO (Estado), 2006:8).

\footnotetext{
60 De acordo com Silva (1975:57), a ligação rodoviária entre São Sebastião e Caraguatatuba aconteceu em 1938 e a ligação entre Caraguatatuba e Ubatuba só foi efetivada na década de 1950.

61 SP-99 - Rodovia dos Tamoios - Na década de 1950 veio uma grande mudança com a construção da Rodovia dos Tamoios (asfaltada em 1960), que liga o planalto a Caraguatatuba.

62 SP-125 - Rodovia Oswaldo Cruz - interliga as cidades de Taubaté, no Vale do Paraíba, e Ubatuba, iniciando suas atividades em 1976 e, de acordo com o site do DER, essa rodovia" teve como origem um antigo traçado de tropeiros que passava por São Luís do Paraitinga indo em direção ao Bairro do Registro em Ubatuba, local onde se registravam as mercadorias que saiam e chegavam ao porto. Durante os anos de 1932 e 1933, o DER, juntamente com presidiários da llha Anchieta, promoveu o alargamento da estrada e o seu calçamento com pedras, de forma a permitir a passagem de veículos automotores. Em 1960, iniciou-se a implantação de um projeto de rodovia mais moderno, com retificações no traçado de São Luís do Paraitinga a Ubatuba, permanecendo o antigo traçado em terra. Entre 1963 e 1969, as obras foram realizadas, sendo a pavimentação concluída em 1969. No período de 1971 a 1979, foram executados diversos melhoramentos na rodovia, cuja utilização é intensa por moradores de Taubaté e cidades da região que desejam alcançar as praias de Ubatuba".

${ }^{63}$ A rodovia Rio Santos, cujo nome oficial é BR-101 - Rodovia Governador Mário Covas, deveria ligar os municípios do Rio de Janeiro a parte continental de Santos. No entanto, para chegar até a cidade de Santos outras rodovias precisam ser acessadas. Como é o caso por exemplo, da SP 55, que liga Ubatuba a São Sebastião. No entanto, todo esse trajeto acabou ficando conhecido como "a Rio-Santos" e é assim que será considerada no presente trabalho. Da mesma forma, a fim de simplificar sua data de utilização, visto que a abertura de trechos que interligavam os municípios foi entregue em datas diversas, vou considerar a partir da década de 1970.
} 
A partir desse ponto, vou abordar essa trajetória nos municípios estudados de forma individualizada, considerando da mesma forma que no item 3.1.1., de acordo com a inserção geográfica, respeitando o sentido de norte a sul.

Apesar de o litoral Norte paulista hoje ter sua economia baseada principalmente no turismo, cada município tem sua trajetória histórica própria e sua contribuição nesse cenário. O registro das atividades econômicas de Ubatuba, por exemplo, data do século XVII, conforme observa Saule Júnior,

Oficializada em 1638, a vila de Ubatuba teve seu desenvolvimento assentado na produção agrícola de subsistência, na pesca, e na agromanufatura açucareira escravista. No final do século XVII, sua população era estimada em 2.000 habitantes (SAULE JUNIOR, 2012:7).

Com a expansão agrícola no final do século XVIII e início do XIX, Ubatuba viu as atividades portuárias aumentaram sensivelmente principalmente depois da abertura dos portos, no início do século XIX. Com isso, o município atingiu certa prosperidade econômica em razão de seu porto ter se tornado o escoadouro da produção cafeeira oriunda principalmente do Vale do Paraíba (SAULE JUNIOR, 2012:7). O autor ainda acena para o fato de que o porto de Ubatuba testemunhou a chegada de africanos escravizados durante os séculos XVII e XIX, contribuindo também para a movimentação econômica do município, além de escoar grande parte da produção cafeeira, juntamente com o porto de São Sebastião, das safras colhidas no Vale do Paraíba e no Sul de Minas Gerais (PANIZZA, 2004; CORREIA, 1975:24). Necessário salientar que essa enseada foi utilizada como sítio portuário desde o início da colonização, era ponto de parada das embarcações que faziam a rota Rio-Santos e chegou a conhecer o auge do período açucareiro vicentino (CORREIA, 1975:23).

O mapa abaixo (Mapa 4) mostra a "vila de Ubatuba" e o local onde funcionava o antigo porto. Esse local passou por modificações e adaptações, sendo atualmente utilizado como um entreposto pesqueiro. Está localizado na ilha dos pescadores, na barra do rio grande que desemboca na praia de Iperoig, centro de Ubatuba. 


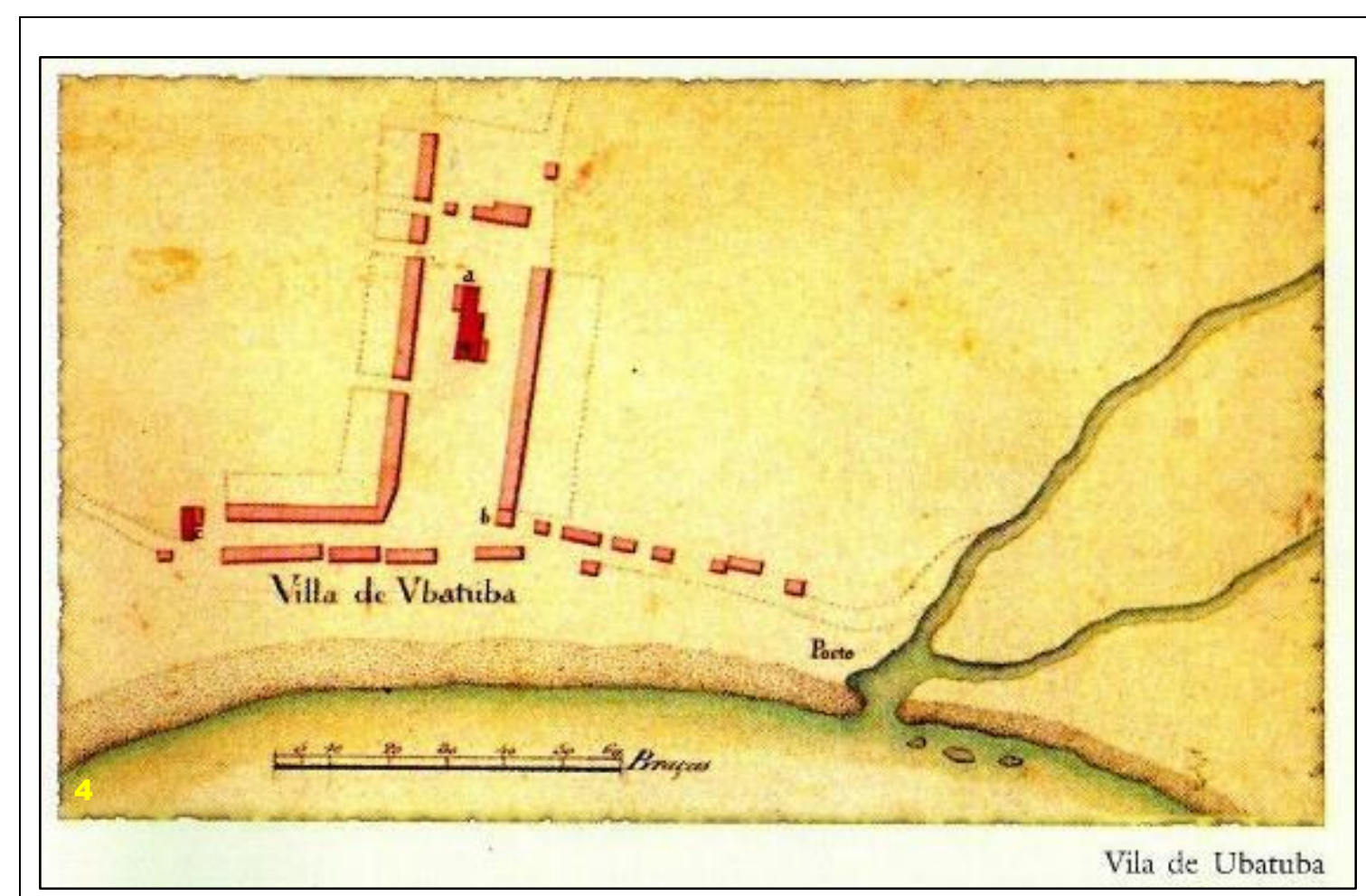

Mapa 4. Mapa antigo indicando a Vila de Ubatuba e o local onde funcionava o antigo porto (Fonte: REIS, 2000).

De acordo com Luna e Klein (2005:17), foi durante o ciclo do café que Ubatuba alcançou o ápice de sua importância na economia colonial, pois foi nesse período que a porção Sul do Vale do Paraíba e as regiões litorâneas do Norte abrigaram as primeiras fazendas de café. Tal fator ocorreu ainda na primeira metade do século XIX, e toda a força de trabalho empregada era movida pela mão-de-obra escrava.

A construção da ferrovia Santos-Jundiaí proporcionou maior facilidade para o escoamento da produção cafeeira no Oeste paulista, provocando, assim, a decadência econômica do Vale do Paraíba e, consequentemente, de Ubatuba e São Sebastião como portos de exportação. Nesse sentido, de 1870 a 1932, Ubatuba vivenciou certo isolamento e sofreu uma desaceleração em sua economia, com suas terras sendo desvalorizadas e grandes residências transformando-se em ruínas. Como resultado, dados demográficos da década de 1940 indicam que Ubatuba se resumia a 3.227 habitantes ${ }^{64}$.

Após esse período, a reabertura e melhoria das estradas, possibilitou que a cidade começasse a se recuperar. A agricultura tem um papel importante no

64 Essas informações foram compiladas do site da prefeitura municipal - disponível em http://www.ubatuba.sp.gov.br/a-cidade/ acessado em 15 de outubro de 2016. 
abastecimento interno do município, sendo que o excedente é vendido para os municípios da região. Segundo dados do IBGE (2006), Ubatuba tem uma produção agrícola baseada principalmente no cultivo da banana, além de lavouras de cana-deaçúcar, de laranja, de feijão, mandioca, soja e milho. Também se observa dados relativos a criação de bovinos, muares, bubalinos, suínos e aves. No entanto, a mola propulsora de sua economia está baseada na exploração do turismo.

Com suas origens recuadas ao século XVII, Caraguatatuba (BORELLI, 2012) tem sua economia baseada inicialmente na agricultura de subsistência, assim como na pecuária e na pesca. Conforme apontado anteriormente, dentre os quatro municípios do litoral Norte paulista, Caraguatatuba possui a maior área de planície e, com isso, podia facilmente desenvolver as lavouras. De acordo com Campos et al (2000:92), a terra não constituía um problema para as famílias, que precisavam apenas se juntar para limpar o terreno e fazer o plantio65.

No século XVIII, o cultivo da cana-de-açúcar nos municípios do litoral Norte paulista teve um grande progresso, principalmente depois da segunda metade do século (CAMPOS et al, 2000:92). O autor ainda acena para o fato de que era no porto do Rio de Janeiro que a exportação dos derivados conseguia os melhores preços e eram facilmente negociados. Com isso, a lavoura de cana-de-açúcar ocupava a maior parte das terras agricultáveis de Caraguatatuba, utilizando pequeno contingente de mão-de-obra escrava para complementar o trabalho familiar. Mas, uma medida66 protecionista tomada pelo governador da Capitania de São Paulo, Bernardo José de Lorena, prejudicaria diretamente as exportações que zarpavam dos portos de Ubatuba e São Sebastião, e com isso, acabaram por inviabilizar o cultivo de cana-de-açúcar e a produção de seus derivados, levando aos municípios do litoral Norte paulista a sérios problemas econômicos.

Como resultado, o número de engenhos na região sofreu uma considerável redução, em função das dificuldades que precisavam ser enfrentadas pelos

\footnotetext{
65 De acordo com o autor, o primeiro plantio que sustentaria o grupo familiar nos primeiros tempos era composto sobretudo por mandioca, milho, abóbora, feijão, arroz e posteriormente incorporou-se produtos que seriam negociados fora do núcleo, como a cana-de-açúcar, o anil, o fumo e, mais tarde, o café (CAMPOS et al, 2000: 92). 66 Objetivando favorecer o comércio de Santos, em 1789, o Governador Bernardo José de Lorena estabeleceu que "não poderão sair açúcares, gomas, arroz, sem que primeiro se alcance licença, porque no caso que os compradores desta Vila (Santos) queiram os ditos efeitos para a carga do navio que estiver ou se esperar neste porto e estão em primeiro lugar" (DI, 31:192-199 apud CAMPOS et al, 2000:94).
} 
produtores que insistiam em se manter ativos com a produção dos derivados da canade-açúcar. No entanto, muitos não resistiram e, segundo Campos, "as dificuldades afastaram os produtores do plantio da cana, com abandono dos engenhos e, às vezes, até mesmo incendiando-os" (CAMPOS et al, 2000: 94). Essa questão só foi resolvida no final de 1798 e o cultivo e processamento da cana-de-açúcar se recuperou rapidamente e, continuou e ser economicamente viável até boa parte do século XIX, quando as começaram a ser parcialmente substituídos pelas lavouras de café.

As plantações contínuas de café produziam lucros crescentes, que eram aplicados na compra de escravos, disponibilizando mais braços para uma produção ainda maior. A crescente auto-suficiência da fazenda, proporcionada pela mão-de-obra barata, a abundância e o auto preço das terras, colaborou para que se suportassem as experiências iniciais e o café se tornasse a viga mestra da economia (CAMPOS et al, 2000:102).

Segundo Campos (et al, 2000:102), em dados de 1835, é evidente o crescente interesse pelo cultivo do café por causa dos altos preços obtidos na exportação. Nesse sentido, outros itens ${ }^{67}$, apesar de ainda serem produzidos, aparecem de maneira inconsistente nos documentos consultados, fazendo parecer que Caraguatatuba, assim como os outros municípios do litoral Norte paulista, tivessem apenas produzido cana-de-açúcar no início do século XIX e café no restante dele (CAMPOS et al, 2000).

Da mesma maneira que aconteceu em Ubatuba, Caraguatatuba também foi impactada pela construção da ferrovia Santos-Jundiaí e acabou sofrendo um declínio econômico, que só mostrou sinais de recuperação no século XX, por meio da abertura de caminhos que possibilitam alcançar o município por via terrestre, permitindo, assim, que as belezas naturais da região pudessem ser exploradas.

No início do segundo quartel do século XX, Caraguatatuba sediaria a Fazenda dos Ingleses, que segundo Santos era uma

(..) extensa retro-área em contraponto à exiguidade de terras planas das cidades irmãs abrigaria um importante complexo agrícola industrial, a Companhia Brasileira de Frutas. Mais conhecida como Fazenda dos Ingleses, instala-se com capital britânico em 1927, tendo funcionado por 40 anos (SANTOS, 2011:27).

Caraguatatuba ainda viria a sofrer um duro golpe em sua trajetória rumo ao desenvolvimento econômico e social. Em março de 1967 o município foi surpreendido

\footnotetext{
67 Pode-se incluir a farinha, o fumo, entre outros (CAMPOS et al, 2000:103).
} 
por uma terrível tempestade, que, devido à grande quantidade de chuva que caiu, foi inevitável que acontecessem grandes deslizamentos de terra, rochas e árvores das escarpas dos morros que margeiam a planície caraguatatubense. Essa catástrofe ambiental provocou centenas de mortes, enlameando e aterrando plantações, áreas de pastos e grande parte das habitações existentes na época. Provocou um grande impacto na economia da cidade, que precisou de ajuda de outros municípios do estado para se reconstruir e se reestruturar. Reconstruiu-se bravamente e hoje, por situações logísticas e funcionais, consolidou-se como principal entreposto de bens e serviços, cumprindo o papel de ligação entre o litoral e a região do Vale do Paraíba (DAHER, 2011).

Nesse sentido, atualmente pode-se observar que o crescimento da mancha urbana de Caraguatatuba seguiu basicamente dois vetores: um ao longo da rodovia SP-55, em paralelo à orla marítima, e outro transversal, da orla marítima em direção à Serra do Mar. Padrão esse também identificado em outros municípios do litoral paulista, cuja urbanização se acomoda nas planícies circunscritas entre o mar e as escarpas. Como não poderia deixar de ser, grande parte de sua economia atualmente está baseada na atividade turística.

A evolução histórica de São Sebastião apresenta alguns aspectos correlatos à trajetória econômica e social brasileira, como a fase da mineração e o contato comercial com o planalto, por exemplo (SILVA, 1975:79-90). Nesse sentido, Bornal destaca que

(...) nos primeiros anos de sua ocupação, o núcleo urbano pouco se desenvolveu, pois, o açúcar nordestino e depois o das Antilhas eram mais vantajosos comercialmente, aspectos que contribuíram para que os engenhos da região se dedicassem à produção de aguardente (BORNAL, 2008:49).

No final do século XVIII, em plena expansão das lavouras de cana, São Sebastião chegou a possuir cerca de 25 engenhos ligados ao fabrico do açúcar e da cachaça. Além do cultivo da cana-de-açúcar, destinada principalmente a produção de aguardente, Almeida (1959) aponta que as terras do município eram excelentes para o cultivo de fumo, algodão, cereais e posteriormente o café.

Conforme citado anteriormente, as sanções aplicadas aos municípios do litoral Norte paulista, obrigando que as exportações fossem feitas pelo porto de Santos, 
também trouxeram incalculáveis prejuízos para São Sebastião, que só conseguiu se recuperar no final do século XVIII, ainda com a produção dos derivados da cana-deaçúcar. No entanto, ainda na primeira metade do século XIX, a expansão das lavouras cafeeiras também abarcaria São Sebastião, que nessa nova fase vivenciaria uma "passagem gradual do açúcar para o café" (BORNAL, 2008:53) com o aproveitamento dos africanos escravizados que trabalhavam nos engenhos, que acabavam fornecendo "certas condições básicas para a expansão do café". Para Bornal (2008),

(...) até o século XIX, o município teve destaque como centro econômico; os engenhos e as fazendas de café geraram riqueza ao mesmo tempo em que promoveram grandes alterações na paisagem (BORNAL, 2008:1).

Mas, a produção cafeeira acabou entrando em decadência, pois, de acordo com Bornal (2008)

(...), a partir da segunda metade do século XIX, São Sebastião, juntamente como os demais municípios do Litoral Norte paulista, começa a vivenciar a decadência das lavouras cafeeiras na região. São os fatores responsáveis o esgotamento das terras e conseqüente queda na produtividade dos cafezais: a expansão do café no Vale do Paraíba, o fim do tráfico negreiro, a implantação mais tarde da ferrovia entre São Paulo e Rio e Janeiro, o Porto de Santos e a própria abolição da escravatura, acarretando a estagnação econômica e o processo de ruína de inúmeras fazendas (BORNAL, 2008:51).

Nesse sentido, com o fim do sistema escravocrata, São Sebastião entra novamente numa fase de inércia econômica, provocando uma diminuição em sua população acarretando uma menor produção agrícola e significativa diminuição na geração de renda, no entanto, tal situação potencializou a diversificação das atividades a fim de garantir sua subsistência. Ainda de acordo com Bornal (1995:31), é nesse período que a pesca artesanal ganha força, apesar de sempre ter feito parte da vida da população, entretanto, agora essa atividade, por força das circunstâncias foi intensificada, tendo sido fundamental à sobrevivência da população. As atividades agrícolas de subsistência que resultavam na venda dos excedentes ${ }^{68}$, proporcionavam a entrada de pequenos valores que permitiam a aquisição de outros produtos. O porto de São Sebastião foi testemunha das agruras que a população vivenciou no final do século XIX e início do XX e com pequenas alterações em suas instalações, manteve-se como entreposto de comércio regional ao final da era dos

\footnotetext{
68 Produtos como peixe seco, feijão, milho, mandioca, farinha, entre outros, eram embarcados em canoas de voga e comercializados em Santos (BORNAL, 1995:31).
} 
grandes veleiros e foi somente na década de 1920 que se viu a necessidade e a conveniência de se criar um porto público no município de São Sebastião. A previsão de que as obras no porto terminassem no início da década de 1940 não se concretizou e essa situação durou até o final da primeira metade do século $X X$. $A$ inauguração oficial do Porto de São Sebastião foi em janeiro de 1955, sendo que na década de 1960 a Petrobras inicia a construção do TEBAR $^{69}$ (Terminal Marítimo Almirante Barroso) destinada ao transporte do petróleo e de seus derivados.

Nesse sentido, a história socioeconômica de São Sebastião sempre esteve entrelaçada com o desenvolvimento da atividade portuária na região, sendo inicialmente pelo surgimento de seu porto histórico, "seguindo-se pela construção do porto organizado e a instalação do terminal marítimo" (REIS, 2011:1).

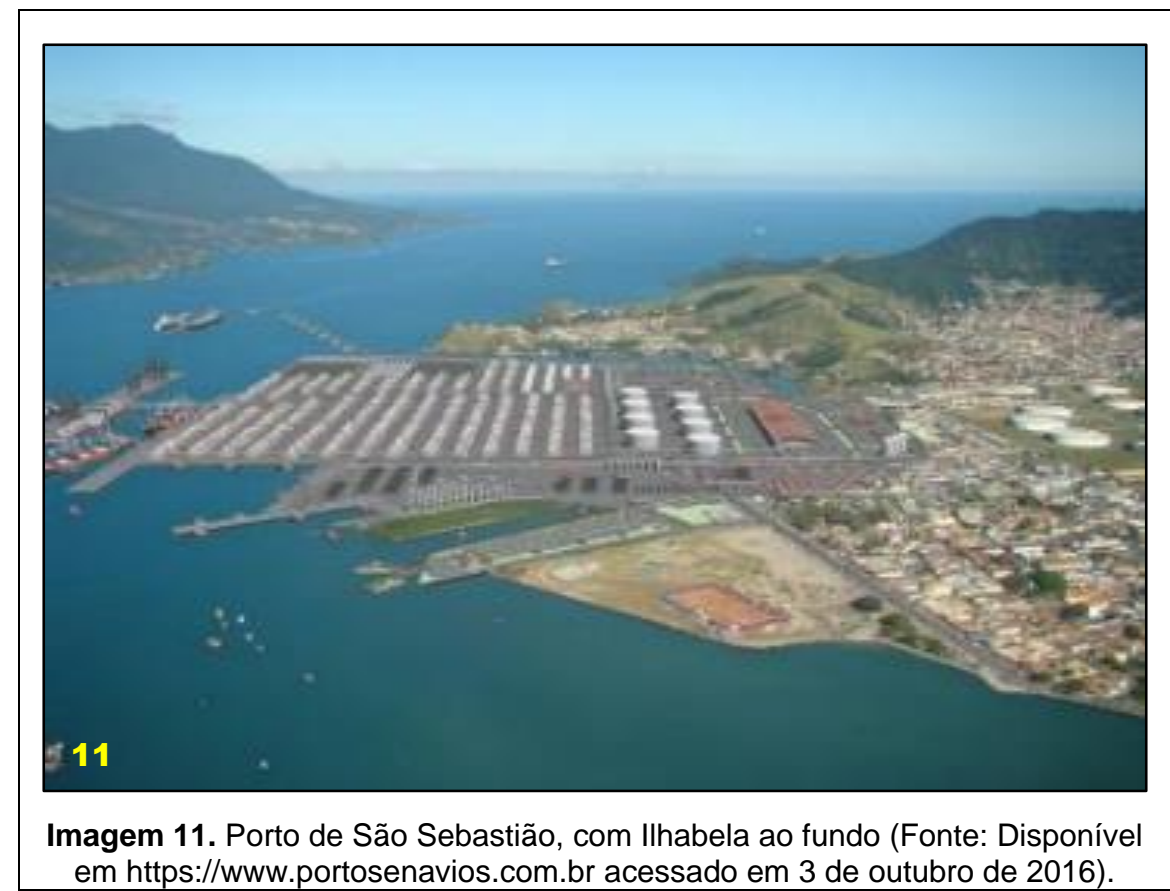

A Imagem (imagem 11) acima mostra o porto organizado de São Sebastião com o depósito do TEBAR à direita da imagem, sendo o porto um marco extremamente importante na história do município.

A ilha de São Sebastião, principal ilha do município de Ilhabela, foi desmembrada da parte continental do município homônimo em 1806, com o nome de Villa Bella da

69 O Terminal Marítimo Almirante Barroso, também conhecido como TEBAR, foi construído na década de 1970 pela Petrobras. Atualmente o terminal é composto por ponte de acesso e píer, totalizando 1600 metros e recebe em torno de 720 navios petroleiros por ano, sendo que por este terminal passa em torno de $50 \%$ do petróleo brasileiro. 
Princesa (SANTOS, 2011:19). Em função disso, os documentos existentes registram os acontecimentos históricos do município de São Sebastião como um todo, o que acaba tornando praticamente impossível apontar nos textos características específicas relativas à parte continental e à parte insular (BENDAZZOLI, 2014:48). Desde então, a formação administrativa ${ }^{70}$ do município conheceu avanços e retrocessos e, apenas em 1944, passou a denominar-se llhabela. Nesse sentido, optei por considerar os aspectos econômicos ${ }^{71}$ de llhabela a partir do século XIX, quando as lavouras de cana-de-açúcar ainda dominavam as terras agricultáveis e os engenhos de cana e aguardente estavam ainda em plena atividade.

Mas, da mesma forma que os outros municípios do litoral Norte acabaram substituindo a maior parte das lavouras de cana-de-açúcar pelos cafezais, llhabela também foi seduzida pelos altos preços alcançados pelo café vindo do Vale do Paraíba e dos municípios vizinhos e suas planícies e morros testemunharam, no segundo quarto do século XIX, a invasão dos pés de café.

De acordo com Paulo Noffs,

(...) a febre do café alastrou-se por llhabela. Novas fazendas foram abertas e antigos engenhos de açúcar fecharam, trocando suas plantações pela cafeicultura. Os cafezais subiram os morros até cotas superiores a $500 \mathrm{~m}$, estabelecendo limites territoriais que não foram ultrapassados por nenhuma outra forma de cultivo, anterior ou posterior a sua passagem (NOFFS, 2007:16).

De acordo com França (1954) no auge ${ }^{72}$ da produção cafeeira no século XIX, Ilhabela chegou a ter 225 fazendas de café e a utilizar a mão-de-obra de mais de 1700 africanos escravizados, com uma colheita de 112.500 arrobas.

Mas o embargo às exportações também afetou a economia de llhabela, que, após um período de estagnação econômica retomaria, ainda que timidamente, a

\footnotetext{
70 De acordo com informações obtidas no site do IBGE, "a unidade político-administrativa compreendendo as ilhas de São Sebastião, Búzios, Vitória e outras ilhotas, foi decretada por ordem do Governador da Província de São Paulo, o Capitão-General Antônio José de França e Horta, em 1805, que a chamou de Villa Bella da Princesa, em homenagem à Princesa da Beira. Reduzido à condição de Distrito de Paz, em maio de 1934, foi incorporado ao Município de São Sebastião e novamente elevado a Município em setembro do mesmo ano, passando a denominar-se Formosa, em 1940, e quatro anos depois, Ilhabela" (IBGE, disponível em http://www.cidades.ibge.gov.br. Acessado em 16 de outubro de 2016).

71 No entanto, faz-se necessário citar a Praia da Armação, de onde desde 1734 funcionava uma das mais importantes armações de baleia do litoral paulista. De lá era extraído o óleo de baleia, utilizado para iluminação pública no Rio de Janeiro e também era um dos produtos de exportação (ELLIS, 1969).

72 De acordo com França, essas informações são relativas ao ano de 1854 (FRANÇA, 1954:145).
} 
produção agrícola, notadamente a cana-de-açúcar para a fabricação de cachaça e a teria como principal atividade econômica até a metade do século XX.

Com a abertura de estradas que ligavam o planalto aos municípios do litoral Norte paulista na segunda metade do século $X X$ e, com o funcionamento da balsa ${ }^{73}$ que liga o continente a Ilhabela, o município começou a prosperar. Com grande área coberta pela mata atlântica, com características geográficas e climáticas que corroboram para a atividade turística, o município veio se consolidando ao longo do século XX e XXI como um importante polo turístico, sendo o turismo a base da economia ilhabelense (CAMPOS et al, 2005:3).

De uma maneira geral o "boom" causado pela cultura cafeeira no século XIX na região acompanhou o desenvolvimento que acontecia na macrorregião do entorno, visto o cultivo no Vale do Paraíba paulista e fluminense. No entanto, devido a outros fatores já apontados ao longo desse item, como decisões políticas, fim do tráfico negreiro, entre outros, para Paulo Noffs

(...) as terras e o clima do Litoral Norte não eram apropriados à cafeicultura que, restrita às exíguas baixadas litorâneas e às encostas próximas, não teve como se expandir. Os solos pobres, de baixa fertilidade, logo se exauriram, consumidos pela erosão e suas práticas agrícolas rudimentares. A região perdeu, ainda, com a abertura da Estrada de Ferro Central do Brasil, sua condição natural de exportadora da produção do Vale do Paraíba. As antigas rotas dos tropeiros, abertas ainda no período da mineração, que do Vale alcançavam Ubatuba (via Taubaté e São Luiz do Paraitinga) e São Sebastião (via São José dos Campos e Paraibuna ou Salesópolis), foram progressivamente abandonadas, pois as mercadorias passaram a ser transportadas por ferrovias para as cidades do Rio de Janeiro e de Santos (NOFFS, 2007:16).

Importante destacar que ao longo da história econômica do litoral Norte paulista, encontra-se alternância de momentos de dinamismo e de quase estagnação. Nesse sentido, a região vivenciou no século XVIII um período de avanço com as lavouras canavieiras e com a movimentação portuária da produção procedente da própria região e do Vale do Paraíba, exportada por meio dos portos de Ubatuba e São Sebastião (CARDOSO, 1996). No entanto, este dinamismo acabou sendo freado em

\footnotetext{
${ }^{73}$ Ao lado direito do porto, fica o local de atracamento da balsa que faz a travessia de São Sebastião para llhabela. Hoje, esse trajeto (2300 metros) dura aproximadamente 20 minutos e é o principal meio de transporte utilizado para acessar a ilha. A balsa começou a funcionar em 1959 e, a partir de então, o município passou a receber mais turistas, vindos principalmente da capital paulista (CAMPOS et al, 2005:3).
} 
fins do século XVIII, quando o fechamento destes portos, em favor do porto de Santos, provocou uma significativa retração nas lavouras (ALMEIDA,1959). Já na primeira metade do século XIX, de acordo com Cardoso (1996) se observou uma nova diligência com a introdução dos cultivos de café no litoral e Vale do Paraíba. Tal situação acabou perdurando até quando o "núcleo da produção cafeeira se deslocou para as áreas centrais do estado e a integração do porto de Santos à rede ferroviária fez deste o principal escoadouro da produção paulista" (CARDOSO, 1996:28).

Atualmente, a exploração das belezas naturais fomenta as atividades turísticas nos quatro municípios do litoral Norte paulista e sustenta as economias locais.

\subsubsection{Manifestações culturais}

O litoral Norte paulista se destaca também por uma gama considerável de referências culturais, seja pela presença indígena na região ${ }^{74}$, seja na cultura caiçara ${ }^{75}$ em suas mais variadas facetas ou nas manifestações herdadas dos africanos que chegaram na região desde meados do século XVI. Além, é claro, de construções que remetem ao período colonial, presente nos grandes casarões assobradados ou nas antigas sedes de fazendas, remanescentes do ciclo do café.

A cultura caiçara se faz presente em todos os municípios com distintos graus de inserção. Como também acontece com as festividades legadas dos africanos escravizados que aqui chegaram afim de trabalhar nas fazendas de cana-de-açúcar e, posteriormente, nas fazendas de café. Dentre as muitas heranças deixadas por esses homens e mulheres, com certeza a congada tem um papel expressivo nos municípios do litoral Norte paulista. Celebração de destaque nos municípios de São Sebastião, Ubatuba e llhabela, a congada de um modo geral, de acordo com Tomaz (2011) teve sua origem

\footnotetext{
74 Duas aldeias indígenas em Ubatuba e uma na divisa de São Sebastião com Bertioga.

75 De acordo com Diegues (2005), a cultura caiçara está inserida em uma organização econômica e social de reduzida acumulação de capital, além disso, não se utiliza de mão-de-obra assalariada. Fundada em produções de pequenas roças, praticam a pesca e o artesanato e respeitam os recursos naturais, com seus ciclos biológicos e hábitos rústicos. Portanto, o modo de vida caiçara se define mais densamente pela utilização da agricultura de base familiar e da pesca, bem como se insere em pequena produção mercantil, com pequena acumulação, isso quando há excedente na produção (SOUZA e SUZUKI, 2010).
} 
(...) no Brasil com a vinda de povos africanos de origem Banto, oriundo das regiões do Congo, Moçambique, Mina, Angola, entre outras, aqui tornados escravos. A Congada é uma manifestação características da cultura afrobrasileira que encontrou no sincretismo religioso um meio de resistir ao domínio e a imposição etnocêntrica dos valores culturais e religiosos do homem branco (TOMAZ, 2011:21).

Ainda de acordo com Tomaz (2011), mesmo com significativas variações regionais, a Congada se faz presente em grande parte do território brasileiro, sendo bastante significativa também, além do interior São Paulo, no interior de Minas Gerais.

Com uma importante inserção no litoral Norte paulista , a ACUBALIN ${ }^{76}$ Associação de Cultura Banto ${ }^{77}$ do Litoral Norte paulista - vem atuando na região dentro de uma perspectiva de resistência e celebração da cultura Banto, visando desenvolver ações sócio educativas voltadas à promoção da igualdade étnico-racial e de valorização do universo cultural-religioso afro-brasileiro, e vem realizando o mapeamento e o diagnóstico dos terreiros de Umbanda e Candomblé em Caraguatatuba, fomentando campanhas contra intolerância religiosa, além de dar suporte à efetivação da lei $10.639 / 03^{78}$ nos municípios do litoral Norte.

Nesse sentido, elenquei, entre as manifestações culturais identificadas nos municípios, aquelas que remetem diretamente a heranças africanas ${ }^{79}$ para que sejam mais detalhadas. As demais manifestações identificadas até a conclusão da presente pesquisa serão apenas citadas a fim de informar o leitor e estarão dispostas de acordo com a orientação do INRC - Inventário Nacional de Referências Culturais. Ainda assim, é importante ressaltar que diante da riqueza cultural da região, algumas vezes a mesma manifestação cultural aparece em municípios vizinhos destacando facetas distintas.

A cidade de Ubatuba conta atualmente com quatro comunidades quilombolas, certificadas pela FCP (serão detalhadas no item 3.3), duas aldeias indígenas, diversas

\footnotetext{
${ }^{76}$ É uma entidade não-governamental, que atua no litoral Norte, principalmente nos municípios de Caraguatatuba e São Sebastião.

${ }^{77}$ Banto ou Bantu refere-se a um tronco linguístico comum entre os diversos grupos étnicos que vivem na África Central, África do Sul e África e Oriental (MUNANGA, 2007 - documentário N-kisi na diáspora).

${ }^{78}$ Altera a Lei no 9.394, de 20 de dezembro de 1996, que estabelece as diretrizes e bases da educação nacional, para incluir no currículo oficial da Rede de Ensino a obrigatoriedade da temática "História e Cultura Afro-Brasileira", e dá outras providências.

79 Muitas vezes, a referência a herança africana em determinada celebração está inserida em uma festividade maior, como exemplo, a Festa de São Benedito realizada em Ilhabela.
} 
comunidades caiçaras distribuídas ao longo da costa, museus, uma fundação que fomenta a realização de diversas manifestações culturais, pontos de cultura, além de construções tombadas que ajudam a contar um pouco a história do município ${ }^{80}$. A seguir, algumas dessas referências são sinteticamente apresentadas.

$\checkmark$ Ponto de Cultura Olhares de Dentro - é promovido pela Associação da Comunidade dos Remanescentes de Quilombo da Fazenda (ACRQF) e busca valorizar a memória e fortalecer as raízes africanas, está sediado na comunidade do Quilombo da Fazenda Picinguaba e desenvolve principalmente ações voltadas ao teatro e ao circo.

$\checkmark$ Ponto de Cultura Quilombola Escolinha Jambeiro - está alocado no interior da comunidade de remanescentes do Quilombo do Camburi e tem suas ações voltadas ao trabalho de resgate e revalorização das culturas tradicionais e de capacitação da sociedade local em práticas sustentáveis de geração de renda.

$\checkmark$ Capoeira - os praticantes da capoeira em Ubatuba (figura 5), além da oportunidade de praticar uma arte herdada dos negros e com isso ajudar a popularizar a práticas culturais de comunidades afrodescendentes, ainda vem ganhando visibilidade com a participação em campeonatos regionais e, com isso, vendo suas vidas serem modificadas e sua arte valorizada ${ }^{81}$.

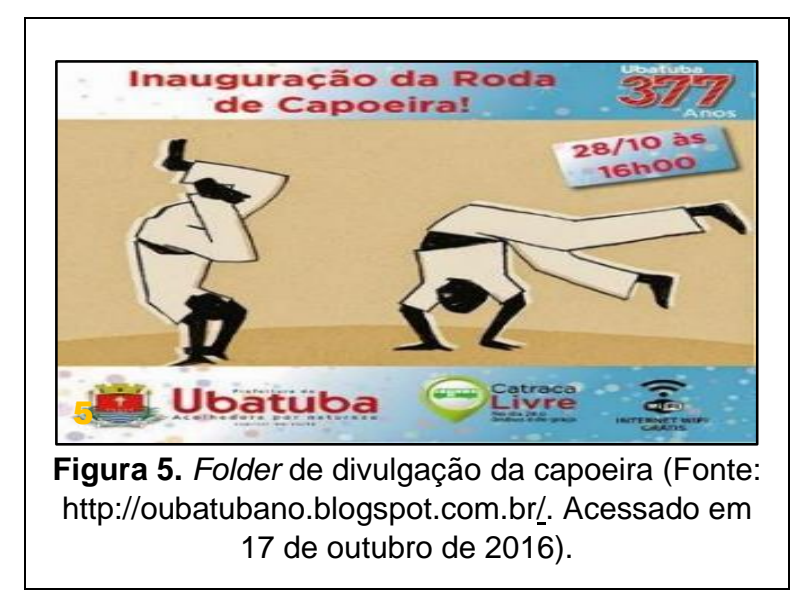

80 Lugares: Aldeia Renascer Ywyty Guaçu, Aldeia Boa Vista Tekoa Nasdeva'e Yuy Marãeyre, Acervo Memória Caiçara, Memorial "Ciccillo Matarazzo"; Celebrações: Folia de Santos Reis Ubatubana, Folia do Divino de Ubatuba, Festa de São Pedro Pescador, Caiçarada, Dança da Fita do Itaguá, Fandango Ubatubano; Edificações: Museu Histórico Washington de Oliveira e Museu Caiçara. Os bens tombados pelo Condephaat e pelo Iphan objetivam assegurar a proteção, valorização e divulgação do patrimônio cultural, a saber: Edifício Paço da Nóbrega, Residência Irmãos Gomes, Ruínas do Engenho da Lagoinha, Sobrado do Porto (atualmente sedia parte das atividades da Fundação de Arte e Cultura de Ubatuba - FUNDART), Casa de Baltazar Fortes, Unidades Habitacionais de Picinguaba.

81 Alguns capoeiristas têm participado de campeonatos regionais, estaduais, nacionais e até o campeonato mundial. A participação tem alcançado ótimos resultados com conquista de medalhas em todas as participações. 
$\checkmark$ Congada de Bastões de São Benedito - acontece no sertão do Puruba e tem sua origem associada a cidade de Cunha/SP. Trazida para Ubatuba por volta de 1940 pelo espanhol Bengno Castro, que instalou na Praia do Puruba uma serraria para beneficiar a caxeta, que na época era uma madeira abundante na região. Os operários contratados eram, em sua maioria, de Cunha e pertencentes a um grupo de Congada. O convívio com os purubanos foi o ponto de partida para a socialização da congada, agora passando a ser realizada também no sertão do Puruba (imagens 12 e 13).

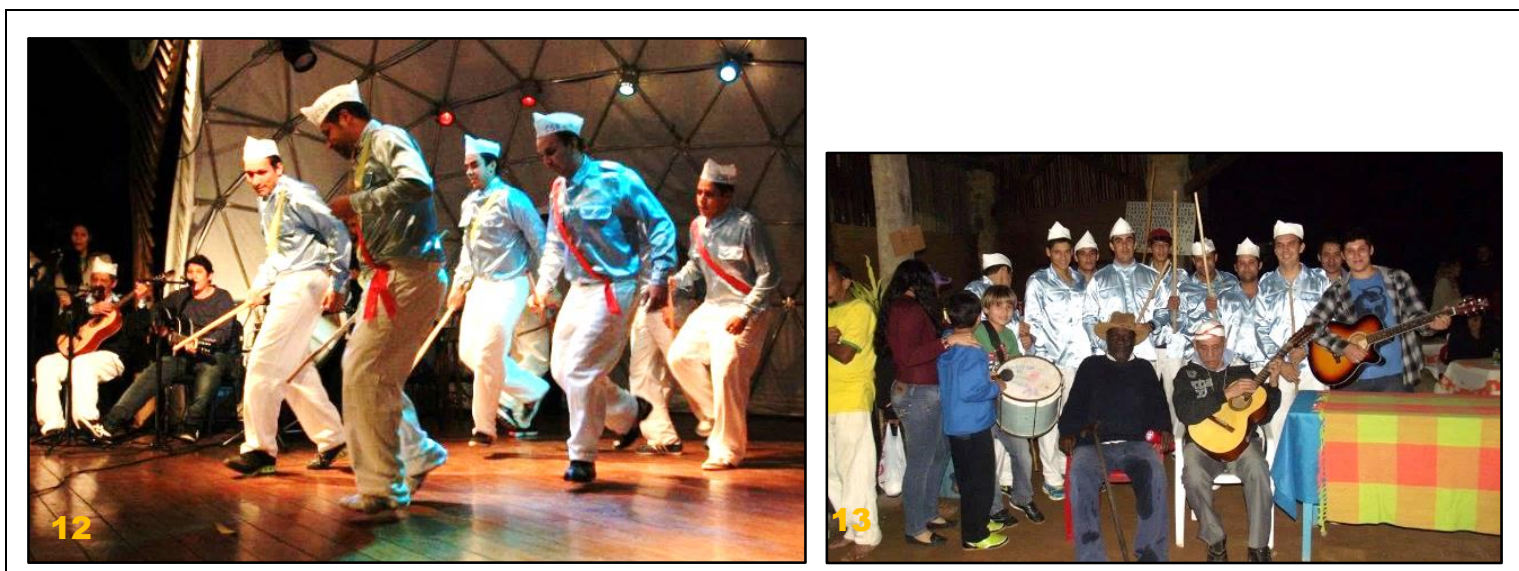

Imagem 12 e 13. Apresentação da Congada de Bastões de São Benedito em 2013. (Fonte: http://www.projetotamar.org.br/noticia1.php?cod=449. Acessado em 16 de outubro de 2016).

Para o município de Caraguatatuba, a principal instituição de fomento as atividades culturais é a FUNDACC - Fundação Educacional e Cultural de Caraguatatuba. Organizando as festividades, recheadas de danças tradicionais, agencia o fortalecimento das referências culturais da cidade ${ }^{82}$. A presença caiçara pode ser reconhecida nas festas, nas danças típicas, no artesanato. Além do museu, dos centros culturais ${ }^{83}$, dos polos culturais espalhados pela cidade, Caraguatatuba se sobressai dos demais municípios do litoral Norte, pela significativa presença das manifestações com herança africana, ainda conta com uma organização não governamental, a Ong Zambô - Zambô do Movimento Negro de Caraguatatuba -, que

82 Celebrações: Folia de Reis - Cia Folia de Santos Reis de Santo Antônio, Festa de Santo Antônio, Puxada de Rede; Edificacões: MACC - Museu de Arte e Cultura de Caraguatatuba. Importante apontar que atualmente não foram identificadas referências à realização da Congada em Caraguatatuba, no entanto, segundo Lima (et al, 1981), até a década de 1950 ela era realizada. De acordo com a autora "por razões econômicas: falta de dinheiro para aquisição de indumentária e tempo para ensaiar, assim como desinteresse dos festeiros pela participação da Congada nas suas festas; religiosas: proibição dos padres; e social, atenção dos seus velhos participantes voltada para outros centros de interesse" (LIMA et al, 1981:79).

${ }^{83}$ Centro Cultural do Travessão, Centro Cultural do Sumaré, Centro Cultural do Massaguaçu, Centro Comunitário do Perequê-Mirim, Centro Comunitário do Poiares, Centro integrado de ações socioeducativas (CIASE) Sumaré e, Centro Comunitário e Cultural "José Agostinho de Souza (Morro do Algodão). 
é uma associação civil beneficente engajada no movimento negro caraguatatubense e que promove diversos eventos durante o ano (imagens 14 e 15).

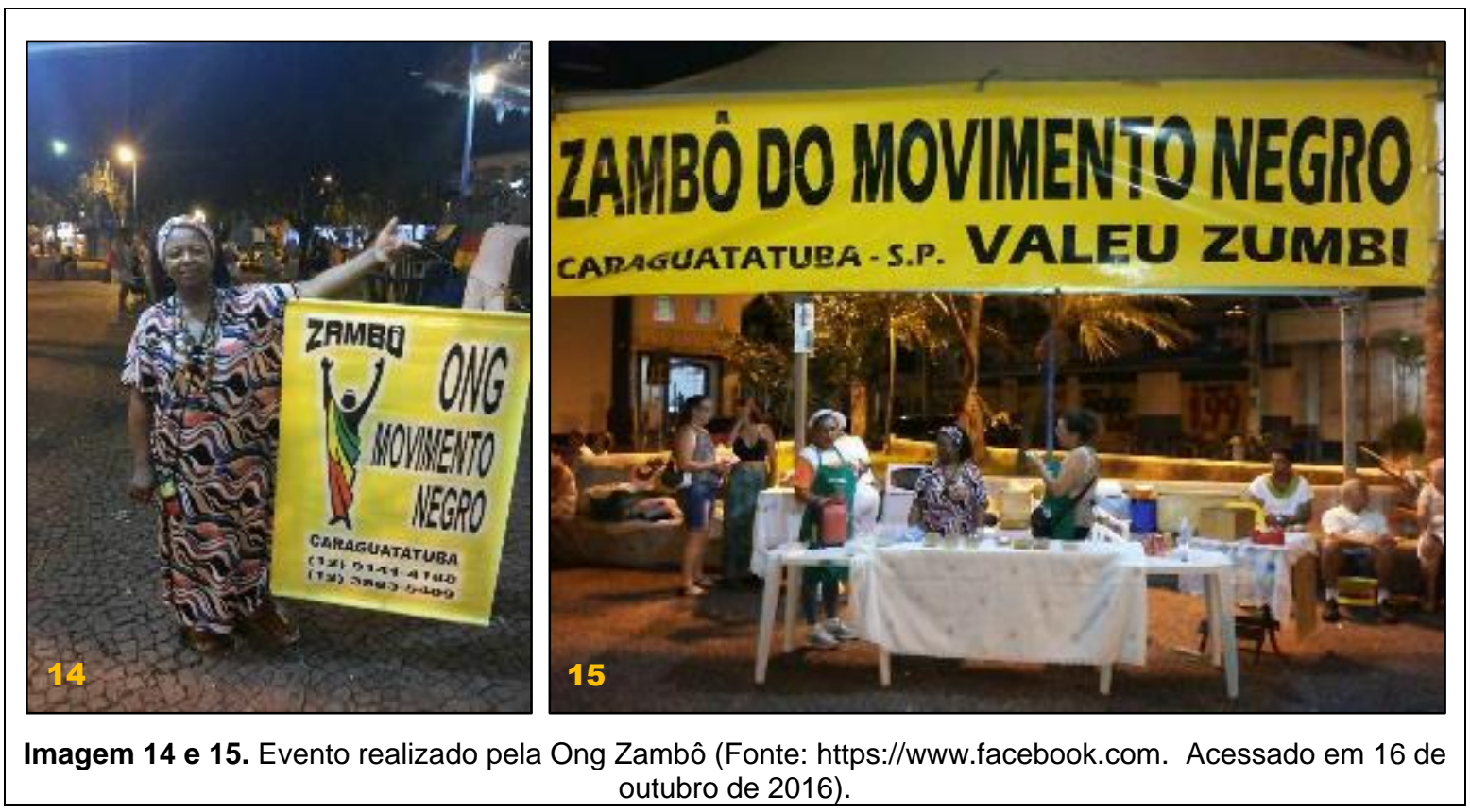

$\checkmark \quad$ Terreiro llê $\tilde{N}$ Zambi84 - reconhecido como patrimônio arqueológico o Terreiro é um templo de candomblé, testemunho da cultura africana banto, em plena atividade nos dias atuais (BASTOS; SOUZA; BORNAL, 2011). Tornou-se, ao longo da história do litoral Norte paulista, uma referência na luta contra o racismo e a intolerância religiosa. A imagem abaixo (imagem 16) exibe os atabaques adornados em dia de toque no terreiro.

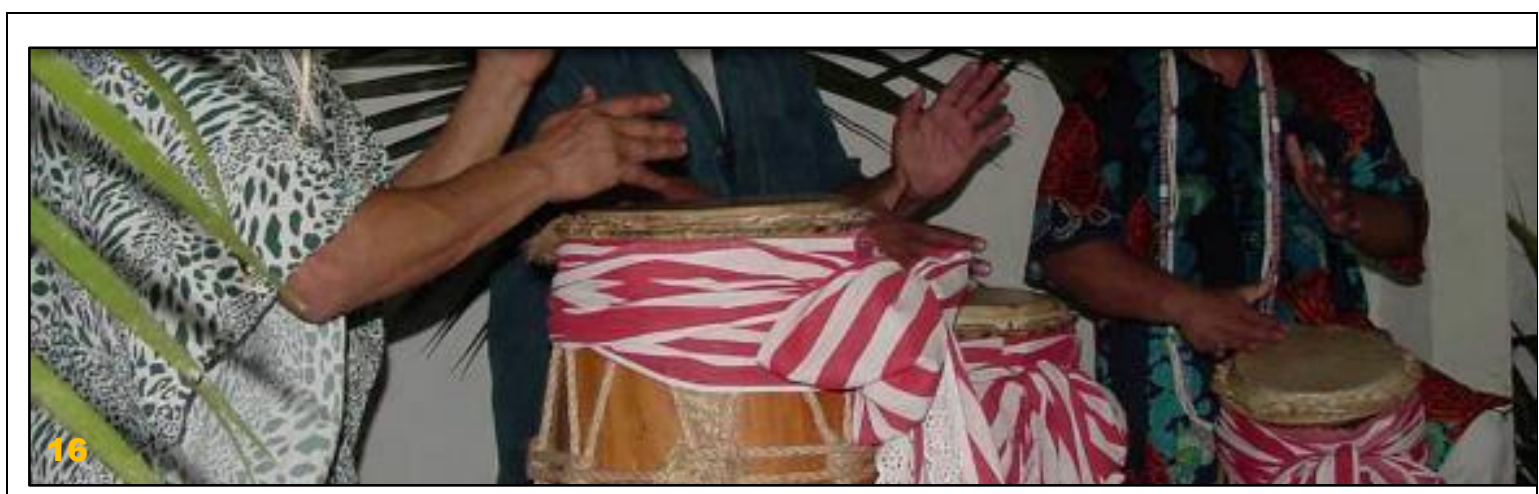

Imagem 16. Detalhe dos atabaques adornados, em dia de toque no terreiro (Fonte: Imagem de divulgação. Disponível em http://ilenzambi.com.br/?page_id=6. Acessado em 16 de outubro de 2016).

84 Informações sobre os trabalhos realizados pela casa, assim como os dias de toque, podem ser obtidos no seguinte endereço http://ilenzambi.com.br/. 
$\checkmark$ Capoeira de Angola - herdada dos africanos, a capoeira que é tombada como patrimônio imaterial pelo Iphan, vem sendo praticada e ensinada no município, visando à ampliação do conhecimento de crianças, adolescentes, jovens e adultos na valorização da cultura negra e, assim, contribuir para a transmissão de disciplina, autoestima, saúde, educação, respeito pela coletividade e cidadania. A oficina de capoeira é ministrada na sede da Ong Zambô.

$\checkmark \quad$ Kizomba - é uma festa dedicada a valorizar, resgatar e manter viva a cultura afro-brasileira, por meio da arte, do artesanato, da dança, nas rezas, nas músicas e nas comidas típicas. Realiza-se em homenagem Zumbi dos Palmares, cuja data comemorativa é em 20 de novembro, dia da consciência negra. Também faz parte das atividades organizadas pela Ong Zambô.

$\checkmark \quad$ Festa de lemanjá - a festa visa homenagear o orixá lemanjá por meio de celebrações religiosas realizadas por adeptos das religiões de cunho africano, notadamente o Candomblé e a Umbanda. Essas celebrações acontecem no entorno da estátua de lemanjá que está alocada na praia do centro, onde os adeptos preparam as oferendas a rainha do mar. Iniciada em 1977, essa celebração tem atraído cada vez mais gente. Na festa de 2015, foi registrada a presença de mais de dez mil pessoas. A imagem abaixo (imagem 17) mostra os fiéis carregando a embarcação com as oferendas que serão entregues no mar em homenagem a lemanjá. Muitas dessas oferendas contêm agradecimentos e/ou pedidos a rainha do mar.

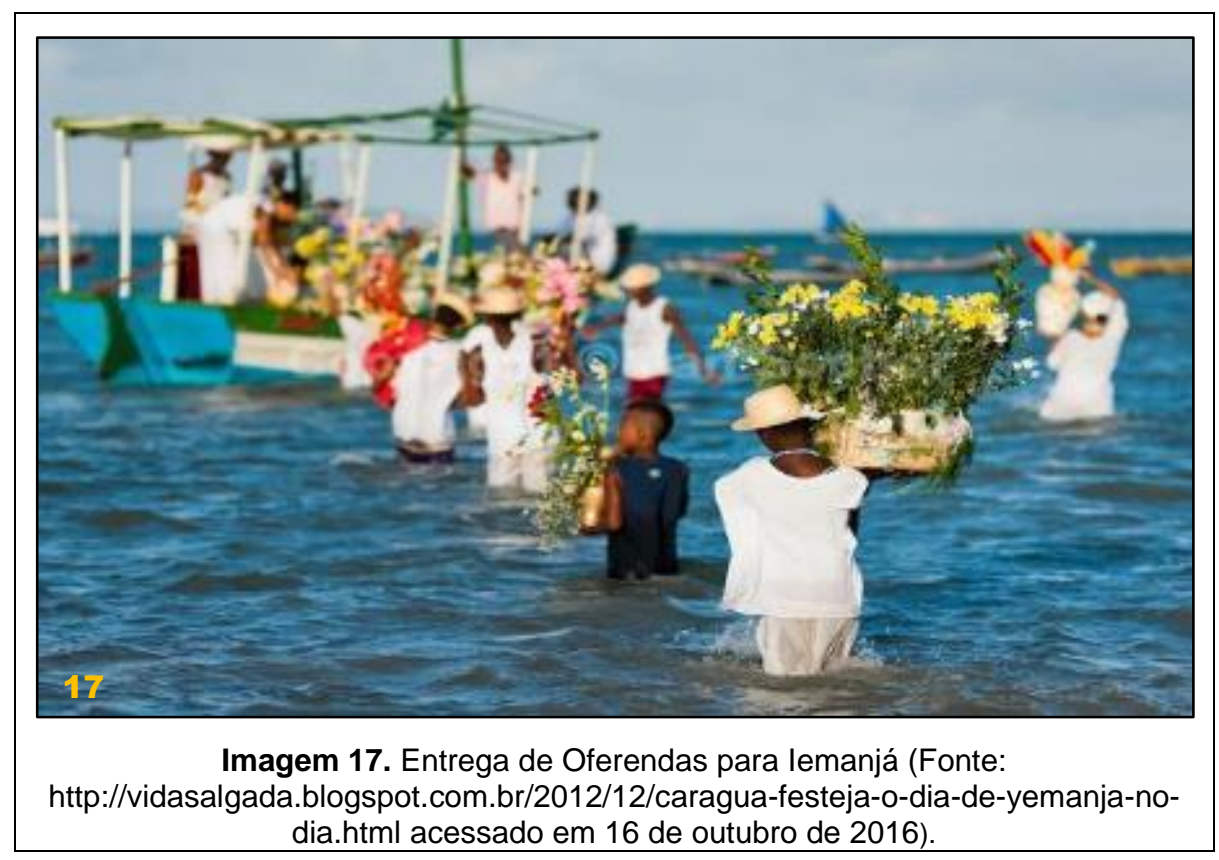


$\checkmark \quad$ Maculelê - caracterizado como um "bailado guerreiro e acrobático", o Maculelê exige grande habilidade dos participantes, principalmente na execução dos saltos e no manejo dos bastões, cujos movimentos e acrobacias mantem uma relação íntima com a capoeira.

Moçambique - considerado patrimônio imaterial, é praticado por grupos religiosos que homenageiam, por meio de suas músicas e danças, os santos padroeiros, principalmente São Benedito e Nossa Senhora do Rosário. As apresentações contêm manobras e manejos de bastões. O moçambiqueiros carregam carreiras de guizos ou pequenos chocalhos de lata.

$\checkmark \quad$ Ponto de Cultura Nkisi na Diáspora: Raízes Religiosas Bantu no Brasil - tem como área cultural de atuação, a música e a dança. Foram produzidos um livro e um documentário ${ }^{85}$ como material de apoio e reflexão sobre educação, racismo e intolerância religiosa. O ponto de cultural localiza-se na sede da ACUBALIN.

$\mathrm{Na}$ cidade de São Sebastião também acontecem várias manifestações ${ }^{86}$ culturais, assim como há a presença de museus, edificações tombadas (imagem 18), entre outros. Além de que, entre as quatro cidades em tela, é a única que tem parte de seu centro histórico ${ }^{87}$ tombado pelo CONDEPHAAT - Conselho de Defesa do Patrimônio Histórico, Arqueológico, Artístico e Turístico.

\footnotetext{
$85 \mathrm{O}$ documentário está disponível no youtube (https://www.youtube.com/watch?v=pCYPhwsP_Kg) e conta com contribuições do antropólogo congolês naturalizado brasileiro, Kabengele Munanga.

${ }^{86}$ Celebrações: Folia de Reis, Puxada de Rede, Lugares: Reserva Indígena Ribeirão Silveira, Fundação Museu de História, Pesquisa e Arqueologia do Mar, Museu de Arte Sacra - Capela São Gonçalo.

$87 \mathrm{O}$ tombamento incidiu sobre sete quadras, além de alguns imóveis isolados como a Capela de São Gonçalo e residências, Cadeia Pública, Igreja Matriz, casa térrea à Rua Antônio Cândido e edifício do Grande Hotel. A técnica construtiva usual dos imóveis mais antigos é a alvenaria de pedra assentada com argamassa de pó de concha e areia, muito comum no litoral (Livro do Tombo Histórico: inscrição $n^{\circ}$ 2, p. 2, 27/04/1971). As outras edificações tombadas são Casa com Teto Pintado ou Casa Esperança, Convento Franciscano de Nossa Senhora do Amparo e a Sede da Fazenda Santana.
} 


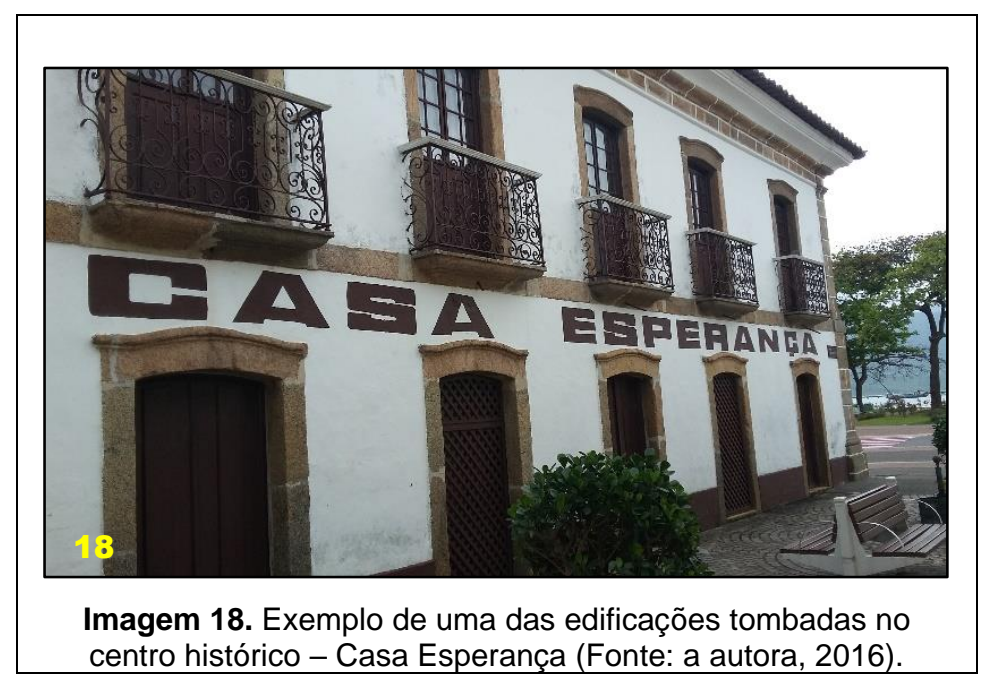

$\checkmark \quad$ Congada de São Benedito ${ }^{88}$ - é a celebração mais tradicional ainda praticada pelas populações locais. Caracterizada por um desfile com elementos da cultura africana (de Angola e do Congo) com influência da igreja católica. Repleta de cantos e danças, o desfile termina na igreja, com a encenação de uma corte e de seus vassalos representando a cerimônia de coroação do Rei do Congo e da Rainha de Angola (imagem 19).

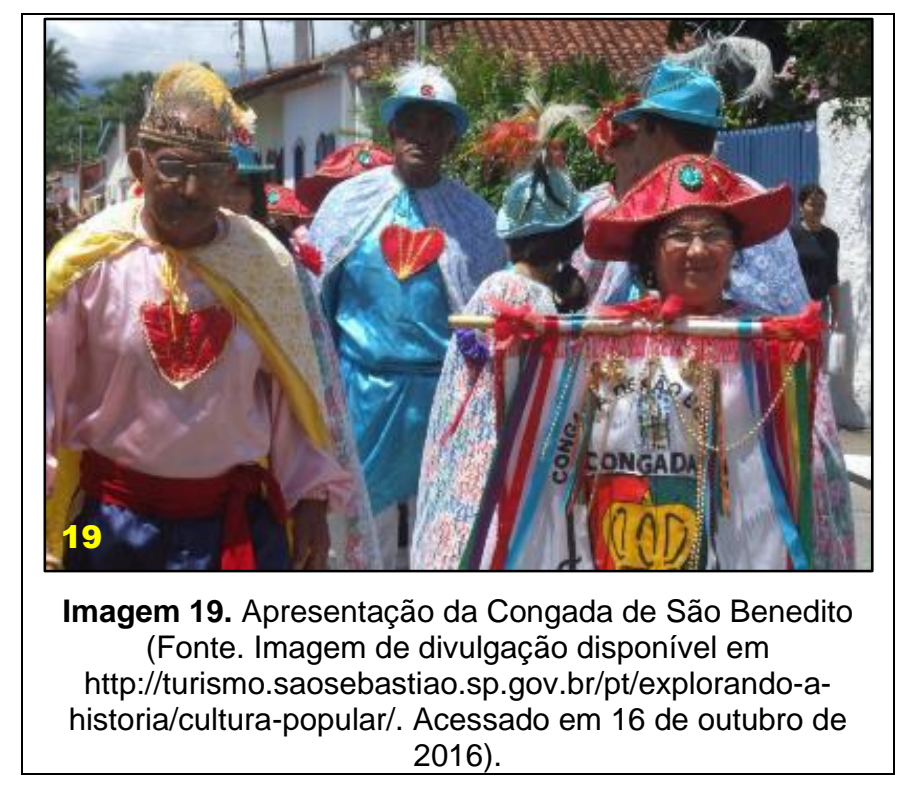

88 De acordo com Lima (et al, 1981), existia uma congada no Bairro de São Francisco, que na época da produção do livro já não era realizada há três anos. Ainda assim, os pesquisadores envolvidos conseguiram mobilizar os antigos congueiros para que a realizassem na Festa de São Benedito. Isso foi feito e a celebração foi amplamente documentada e os resultados podem ser visualizados no livro "O folclore do litoral Norte de São Paulo - de Rossini Tavares de Lima e outros, 1981" (LIMA et al, 1981:23). 
$\checkmark \quad$ Capoeira - trazida pelos africanos, sofreu adaptações ao longo dos tempos, mas acredita-se que durante a vigência do regime escravocrata, a capoeira era realizada em um momento de descontração e alívio da tensão, além de ser importante na manutenção da saúde do corpo. A origem da denominação pode estar associada ao local onde antigamente era praticada, que era em campos abertos com pequenos arbustos, denominados capoeira ou capoeirões. Em São Sebastião, acontece em diversos eventos ao longo do ano.

$\checkmark \quad$ Maculelê - sua origem, porém, como aliás ocorre em relação a algumas das manifestações folclóricas de matriz africana, é obscura e desconhecida, no entanto, o Maculelê é uma expressão popular que conta por meio de danças e cânticos a lenda de um guerreiro que sozinho defendeu sua tribo de um ataque de inimigos, que teria então se armado de curtos bastões de pau e enfrentado os invasores, tornando-se com isso um herói.

$\checkmark \quad$ Samba de Roda - é um acontecimento popular festivo que combina música e dança, ao som principalmente de tambores e, acredita-se que era praticada pelos cativos nas horas de lazer. Em São Sebastião costuma acontecer após as apresentações de capoeira (imagem 20).

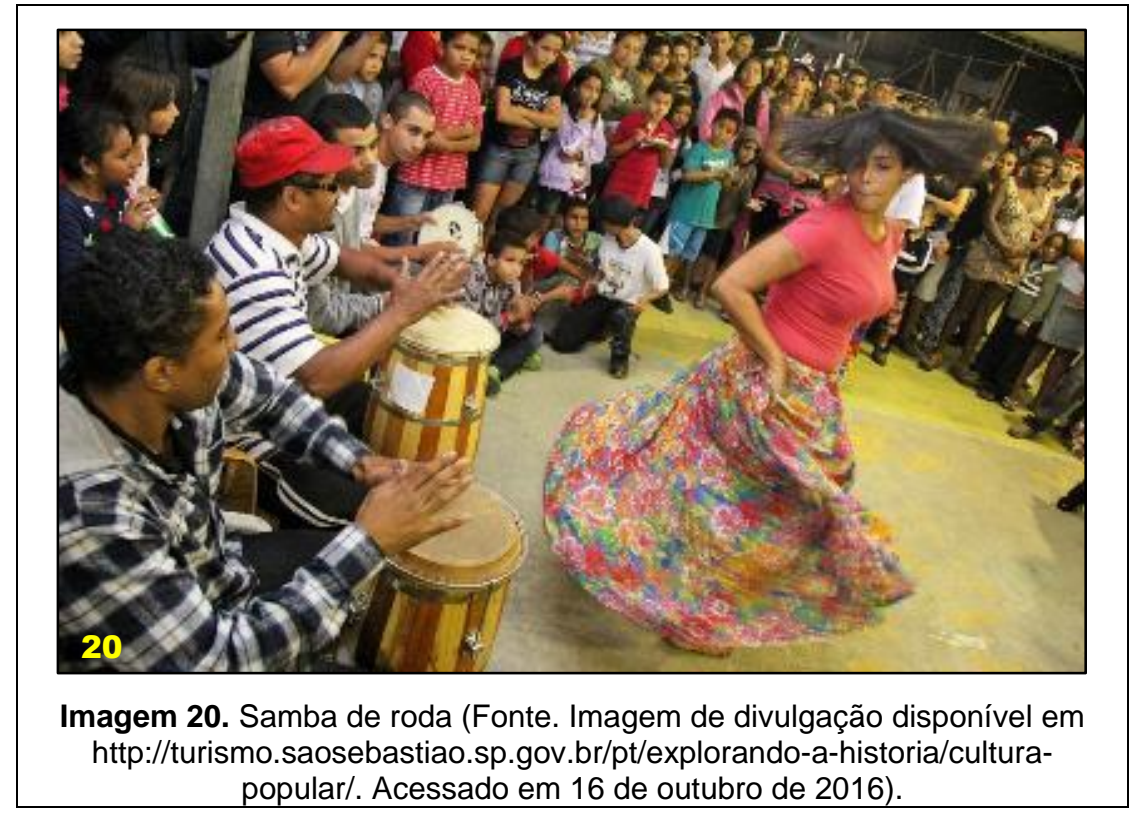


Tendo na Congada sua principal celebração com herança africana, o município de Ilhabela ${ }^{89}$ tem sido palco de ativa dinâmica cultural, tanto com manifestações de comunidades tradicionais caiçaras, quanto com manifestações de descendência africana ${ }^{90}$.

$\checkmark \quad$ Congada de São Benedito - realizada em Ilhabela há mais de 150 anos, aparentemente sem nunca ter sido interrompida. De acordo com Caponero (2009), a festa de São Benedito, na qual a Congada é realizada, recebeu grande influência africana e não se tornou mero entretenimento, "mantendo sua tradição como uma manifestação de grande religiosidade popular, onde o sagrado e o profano estão interligados em uma demonstração de fé e solidariedade que atravessa gerações e se constitui em significativo patrimônio imaterial brasileiro". De acordo com Caponero (2009:213), seu início estaria associado à chegada de navios negreiros vindos da África e que aportaram na Praia dos Castelhanos, carregados de africanos escravizados para trabalhar nas fazendas e também nas casas de colonos. A congada acontece durante a festa de São Benedito (imagem 21).

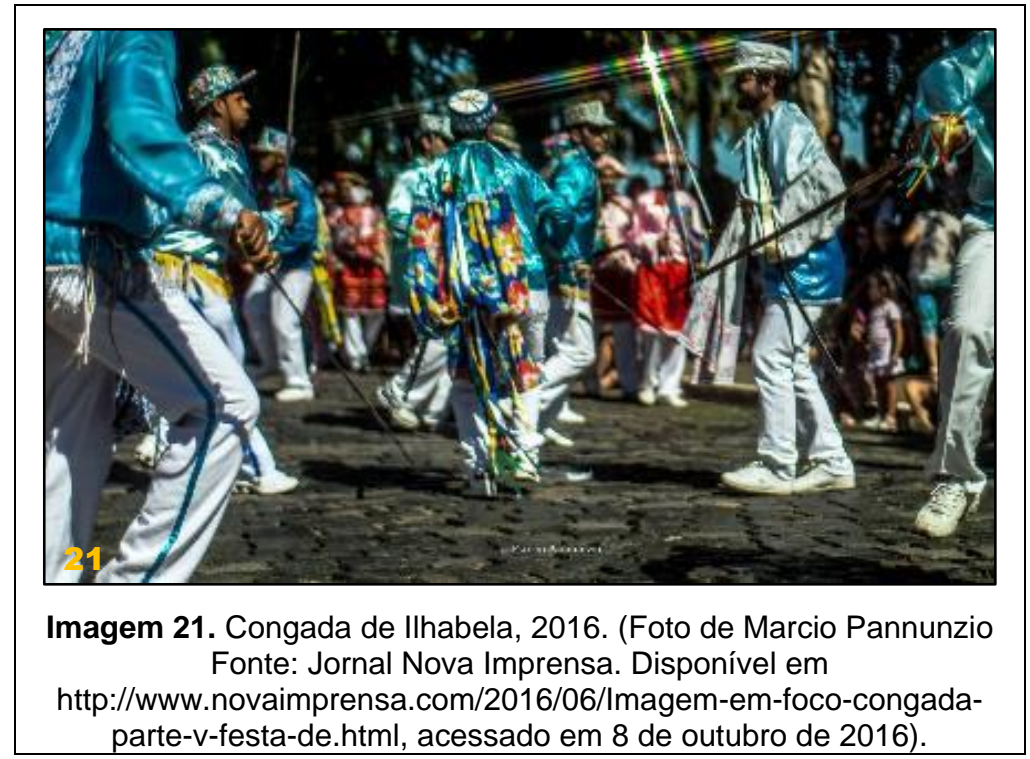

\footnotetext{
$\checkmark \quad$ Festa de São Benedito - a festividades acontecem sempre no mês de maio, no entanto, não há data fixa para acontecer, pois depende também das condições

89 Tem na Fundação de Arte e Cultura de Ilhabela como instrumento de fomento as manifestações artísticosculturais. Edificações: Museu náutico de llhabela. Lugares: Ponto de Cultura Pés no Chão. Celebrações: Festa de São Pedro, Festa de Nossa Senhora D'Ajuda e Bom Sucesso. Além disso também se articula em Ilhabela a AMAI (Associação do Movimento Afrodescendente de llhabela). Bens tombados pelo CONDEPHAT: Cadeia e Fórum de Ilhabela, Sede da Fazenda Engenho D'Água.

90 Em Ilhabela, atua a AMAI (Associação do Movimento Afrodescendente de llhabela).
} 
climáticas, pois é necessário que o céu esteja limpo e a lua ilumine a noite, para que os pescadores dela participem. Atualmente é o conselho paroquial que se incube da parte religiosa e da quermesse. Os pontos principais da programação são a Congada, o levantamento do mastro de São Benedito, o Baile dos Congos, Meia Lua, a Ucharia, o bolo de São Benedito, a queima de fogos e os shows musicais.

De uma maneira geral, o mapeamento realizado sobre as manifestações culturais com herança africana nos quatro municípios do litoral Norte paulista possibilitou identificar, ainda que sem o aprofundamento desejado, a dispersão das manifestações pelo território. A FCP disponibiliza em seu site uma relação de manifestações culturais negras ${ }^{91}$, sendo que algumas acontecem em regiões específicas do país, como é o caso do "Negro Fugido", manifestação mantida há mais de um século pelos pescadores da região do Recôncavo Baiano, na Bahia.

A tabela abaixo apresenta um resumo das manifestações culturais associadas a herança africana e que foram identificadas nos municípios do litoral Norte paulista.

Tabela 1. Referências culturais associadas a herança africana nos municípios do litoral Norte paulista.

\begin{tabular}{|l|l|l|l|l|}
\hline \multicolumn{1}{|c|}{ Referência cultural } & Ubatuba & Caraguatatuba & São Sebastião & Ilhabela \\
\hline Congada & & & & \\
\hline Capoeira & & & & \\
\hline Kizomba & & & & \\
\hline Festa de lemanjá & & & & \\
\hline Maculelê & & & & \\
\hline Moçambique & & & & \\
\hline Samba de Roda & & & & \\
\hline Ponto de Cultura & & & & \\
\hline Terreiro de Candomblé/Umbanda & & & & \\
\hline Festa de São Benedito & & & & \\
\hline
\end{tabular}

Conforme se observa na tabela acima (tabela 1), é no município de Caraguatatuba que as manifestações culturais de herança africana são mais evidentes, seguida pelo município de São Sebastião, Ubatuba e Ilhabela.

91 Afoxé, Bloco Afro, Bumba-meu-boi, Cacuriá, Capoeira, Carreiros, Carimbó, Ciranda, Congada, Escola de Samba, Folia de Reis, Frevo, Jongo, Maculelê, Marabaixo, Maracatu de Baque Virado, Maracatu de Baque Solto, Marujada, Matriz do Samba, Negro fugido, Reisado de Congo, Samba de Coco, Samba de Roda, Tambor de Crioula, Teatro Experimental do Negro (TEN) (FUNDAÇÃO PALMARES, 2016.) 
Caraguatatuba apresenta ainda duas referências associadas aos cultos africanos (Festa de lemanjá e o terreiro de Candomblé Ilê Ñ Zambi), circunstância que não se repete nos outros municípios. No caso do terreiro, tal situação pode estar associada ao preconceito e a intolerância religiosa, o que faz com que ainda alguns terreiros mantenham-se localizados em bairros mais distantes do centro e discretamente ativos.

\subsection{Breve contextualização arqueológica da região}

O litoral Norte paulista apresenta características geográficas e geomorfológicas que determinaram as formas de ocupação pretéritas e contemporâneas. Com ocupações de seu território, tanto na porção continental como nas porções insulares (AMENOMORI, 2005), o litoral Norte tem contribuído para o entendimento do modo de vida dos indivíduos e sociedades que ocuparam a costa litorânea brasileira. Com um potencial significativo, projetos de caráter acadêmico e aqueles desenvolvidos no âmbito do licenciamento de empreendimentos diversos, vêm permitindo que novas evidências sejam identificadas.

A região apresenta ocupações que remetem ao período pré-colonial por comunidades indígenas, inicialmente por grupos pescadores-coletores (AMENOMORI, 2005; BENDAZZOLI, 2014; UCHÔA, 1980, 1981/1982) e, posteriormente, pelo grupo tupinambá, que densamente ocuparam a costa litorânea até a chegada do colonizador europeu. Com isso, além da presença de sítios associados a grupos pescadores-coletores já citados, a região do litoral norte também indica a presença de sítios associados aos grupos ceramistas (SCATAMACCHIA \& UCHÔA, 1993; UCHÔA et al, 1984), no entanto, conforme adverte Bendazzoli (2014)

(...) a falta de informações sobre os povos ceramistas do litoral Norte paulista está diretamente relacionada à raridade de trabalhos arqueológicos com esse enfoque na região, ainda que existam relatos seiscentistas que apontem para a presença massiva de indígenas estabelecidos nessa zona costeira durante o período de contato. Esses relatos focados predominantemente na presença e domínio dos povos Tupi, serviram de base para a maioria dos historiadores posteriores ao período em que foram produzidos (...) (BENDAZZOLI, 2014:270). 
Com um potencial ainda a ser explorado, o litoral Norte carece de mais pesquisas relacionadas tanto ao período pré-colonial, quanto ao período histórico. Ainda que trabalhos acadêmicos venham possibilitando novas descobertas, como o trabalho de Cali (2005) por exemplo, que durante o período em que esteve à frente do Projeto Arqueológico de llhabela $^{92}$, segundo o autor, foram identificados 70 sítios arqueológicos, "entre sítios concheiros, abrigos sob rocha, sítios ceramistas e sítios de ruínas de fazendas, engenhos, igrejas, habitações e fortificações desde o início da colonização portuguesa até o século XIX" (Op. Cit.:85). No entanto, nenhum outro tipo de informação relacionada a esses sítios está disponibilizada no trabalho e esses dados ainda não constam ${ }^{93}$ na base de dados do CNSA-Iphan. Dessa forma, passam a figurar apenas quantitativamente e ratificam o alto potencial da região.

Amenomori (2005), baseada nos pressupostos teóricos da Arqueologia da Paisagem, faz uma abordagem a três sítios arqueológicos com o objetivo de estudar os aspectos fenomenológicos da paisagem pré-histórica insular. Além disso, realizou o cadastro de mais dois sítios arqueológicos associados ao período pré-colonial, todos localizados em Ubatuba

Wagner Bornal conclui sua dissertação de mestrado em 1995 e tem como foco de sua pesquisa as ruínas de uma fazenda escravista, envolta em lendas e em meio a mata atlântica. Em uma implantação nada convencional ${ }^{94}$, as ruínas se revelaram significativas e possibilitaram a continuidade das pesquisas por meio de um doutorado, concluído em 2008. Esse trabalho foi sob a ótica da Arqueologia da paisagem e resultou ainda na identificação de outros sete sítios arqueológicos correlatos ao sítio arqueológico São Francisco 1 (BORNAL, 1995; 2008).

Sob a orientação da Prof ${ }^{a}$. Dr. Scatamacchia, a dissertação de Santos (2011) objetivou "oferecer bases para a consolidação de políticas públicas para o patrimônio arqueológico no município de São Sebastião" e, para isso, o autor percorreu o município no sentido (sentido norte - sul) em caráter amostral. Tal metodologia, de acordo com o autor, "resultou na identificação de 31 sítios arqueológicos, sendo 23

\footnotetext{
92 Segundo Cali (2005), o Projeto Arqueológico de llhabela foi criado em 1999 com o "objetivo de identificar, proteger e promover o patrimônio arqueológico local, através de procedimentos científicos e o desenvolvimento de uma política municipal de gestão desse patrimônio (Op. Cit.: 85).

${ }^{93}$ Consulta realizada em http://portal.iphan.gov.br/pagina/detalhes/236 acessado em 17 de outubro de 2016 .

${ }^{94}$ Situa-se na Serra do Dom entre as cotas altimétricas 90 e $270 \mathrm{~m}$ e entre dois cursos d'água com volume significativo somente nas estações chuvosas.
} 
descobertos durante o programa e 9 já cadastrados anteriormente e inseridos nos sistemas de banco de dados" (SANTOS, 2011:44). As informações disponibilizadas nesse trabalho possibilitam ao leitor um entendimento geral de que tipo de evidências se apresentam, além de permitir sua distribuição espacial por meio da localização geográfica. No geral, os sítios identificados por Santos referem-se ao período colonial, mas também foram identificados sítios com componentes cerâmicos associados ao período pré-colonial.

Bendazzoli (2014), em sua tese de doutorado, objetivou mapear a ocupação sambaquieira do arquipélago de Ilhabela, que resultou no cadastro de 18 sítios arqueológicos associados ao período pré-colonial, conforme pode-se observar na tabela abaixo (tabela 2). Além disso, segundo a autora, foram cadastrados mais 40 sítios arqueológicos associados ao período colonial. Da mesma forma que no trabalho de Cali (2005), esses sítios estão quantificados e associados ao período colonial, mas nenhuma outra informação está disponível. O banco de dados do CNSA-Iphan também não apresenta o resultado desses cadastros, apesar da autora informar que eles já foram cadastrados no Iphan (BENDAZZOLI, 2014:114).

A seguir, na tabela 2 estão indicados os sítios arqueológicos cadastrados para os quatro municípios do litoral Norte paulista, de acordo com as informações disponíveis nos trabalhos acadêmicos acessados e no Banco de dados do - CNSA disponível no site do IPHAN.

Tabela 2. Sítios arqueológicos identificados no Litoral Norte de São Paulo

\begin{tabular}{|l|c|c|}
\hline \multicolumn{1}{|c|}{ Denominação } & Município & Fonte \\
\hline Sítio Engenho Barra Velha I & Ilhabela & CNSA- IPHAN SP00638 \\
\hline Sítio Aldeia Viana & Ilhabela & CNSA- IPHAN SP00639 \\
\hline Sítio Abrigo Furnas I & Ilhabela & CNSA- IPHAN SP00640 \\
\hline Sítio Engenho da Feiticeira I & Ilhabela & CNSA- IPHAN SP00641 \\
\hline Sítio Acampamento Búzios I & Ilhabela & CNSA- IPHAN SP00642 \\
\hline Sítio Acampamento Vitória IV & Ilhabela & CNSA- IPHAN SP00643 \\
\hline Sítio Acampamento Conchífero Mar Virado & Ubatuba & CNSA- IPHAN SP00430 \\
\hline Sítio Tenório & Ubatuba & CNSA- IPHAN SP00431 \\
\hline Sítio Itaguá & Ubatuba & CNSA- IPHAN SP00432 \\
\hline Sítio São Francisco & São Sebastião & CNSA- IPHAN SP00416 \\
\hline Sítio Morro do Abrigo & São Sebastião & CNSA- IPHAN SP00417 \\
\hline Sítio Engenho Pacuíba I & Ilhabela & CALI (2003) \\
\hline Sítio Couves 1 & Ubatuba & AMENOMORI (2005) \\
\hline Sítio Couves 2 & Ubatuba & AMENOMORI (2005) \\
\hline Sítio Vila de Picinguaba & Ubatuba & AMENOMORI (2005) \\
\hline
\end{tabular}




\begin{tabular}{|c|c|c|}
\hline Denominação & Município & Fonte \\
\hline Sítio Montão de Trigo & Ubatuba & AMENOMORI (2005) \\
\hline Sítio Prumirim & Ubatuba & AMENOMORI (2005) \\
\hline Sítio Terreiro de Candomblé Ilê 'N Zambi & Caraguatatuba & ACUBALIN (2011) \\
\hline Sítio Camburu & Caraguatatuba & A Lasca Consultoria \\
\hline Sítio Fazenda dos Ingleses & Caraguatatuba & BORNAL e GALDINO (2011) \\
\hline Sítio Jaraguá 2 & São Sebastião & BORNAL (2008) \\
\hline Sítio Cigarras 1 & São Sebastião & BORNAL (2008) \\
\hline Sítio Mesquita & São Sebastião & BORNAL (2008) \\
\hline Sítio Morro do Abrigo & São Sebastião & BORNAL (2008) \\
\hline Sítio Do Outeiro & São Sebastião & BORNAL (2008) \\
\hline Sítio Cebimar & São Sebastião & BORNAL (2008) \\
\hline Sítio Guaecá & São Sebastião & BORNAL (2008) \\
\hline Sítio Enseada 01 & São Sebastião & SANTOS (2011) \\
\hline Sítio Gaivotas 01 & São Sebastião & SANTOS (2011) \\
\hline Sítio Ventura 01 & São Sebastião & SANTOS (2011) \\
\hline Sítio Forte da Sepetuba 01 & São Sebastião & SANTOS (2011) \\
\hline Sítio Mesquita 01 & São Sebastião & SANTOS (2011) \\
\hline Sítio Neofarm 01 & São Sebastião & SANTOS (2011) \\
\hline Sítio Belvedere 01 & São Sebastião & SANTOS (2011) \\
\hline Sítio Boa Vista 01 & São Sebastião & SANTOS (2011) \\
\hline Sítio Antão Soares 01 & São Sebastião & SANTOS (2011) \\
\hline Sítio Batuíra 01 & São Sebastião & SANTOS (2011) \\
\hline Sítio Vice Rey 01 & São Sebastião & SANTOS (2011) \\
\hline Sítio Fazenda Santana 01 & São Sebastião & SANTOS (2011) \\
\hline Sítio Forte Pontal da Cruz & São Sebastião & SANTOS (2011) \\
\hline Sítio Ipiranga 01 & São Sebastião & SANTOS (2011) \\
\hline Sítio Cemitério Central 01 & São Sebastião & SANTOS (2011) \\
\hline Sítio Calhetas 01 & São Sebastião & SANTOS (2011) \\
\hline Sítio Santiago 01 & São Sebastião & SANTOS (2011) \\
\hline Sítio Paúba 01 & São Sebastião & SANTOS (2011) \\
\hline Sítio Praia Brava de Boiçucanga 01 & São Sebastião & SANTOS (2011) \\
\hline Sítio Boiçucanga 01 & São Sebastião & SANTOS (2011) \\
\hline Sítio Porto dos Faroleiros 01 & São Sebastião & SANTOS (2011) \\
\hline Sítio Abrigo Saco do Funil 01 & São Sebastião & SANTOS (2011) \\
\hline Sítio Abrigo Saco do Funil 02 & São Sebastião & SANTOS (2011) \\
\hline Sítio Jaraguá 1 & São Sebastião & SANTOS (2011) \\
\hline Sítio Pitangueiras 01 & São Sebastião & SANTOS (2011) \\
\hline Sítio Toque Toque - 01 & São Sebastião & SANTOS (2011) \\
\hline Sítio Toca do Eustáquio & Ilhabela & BENDAZZOLI (2014) \\
\hline Sítio Toca do Caramujo & Ilhabela & BENDAZZOLI (2014) \\
\hline Sítio Polidor da Figueira & Ilhabela & BENDAZZOLI (2014) \\
\hline Sítio Toca do Mirante & Ilhabela & BENDAZZOLI (2014) \\
\hline Sítio Porto da Toca & Ilhabela & BENDAZZOLI (2014) \\
\hline Sítio Porto do Meio & Ilhabela & BENDAZZOLI (2014) \\
\hline Sítio Abrigo Guanxumas & Ilhabela & BENDAZZOLI (2014) \\
\hline Sítio Mãe Joana & Ilhabela & BENDAZZOLI (2014) \\
\hline Sítio Toca da Paixão & Ilhabela & BENDAZZOLI (2014) \\
\hline
\end{tabular}




\begin{tabular}{|l|c|c|}
\hline \multicolumn{1}{|c|}{ Denominação } & Município & Fonte \\
\hline Sítio Toca da Caveira & Ilhabela & BENDAZZOLI (2014) \\
\hline Sítio Costão & Ilhabela & BENDAZZOLI (2014) \\
\hline Sítio Toca do Barro Vermelho & Ilhabela & BENDAZZOLI (2014) \\
\hline Sítio Abrigo do Beto & Ilhabela & BENDAZZOLI (2014) \\
\hline Abrigo Sul & Ilhabela & BENDAZZOLI (2014) \\
\hline Sítio Toca do Ramiro & Ilhabela & BENDAZZOLI (2014) \\
\hline Sítio Toca do Gentio & Ilhabela & BENDAZZOLI (2014) \\
\hline Sítio Terra Preta & Ilhabela & BENDAZZOLI (2014) \\
\hline Sítio Paredão & Ilhabela & BENDAZZOLI (2014) \\
\hline
\end{tabular}

De acordo com Santos (2011:27), "inúmeras fontes documentais, toponímicas e geoindicadoras oferecem imenso potencial ainda a ser descoberto". Certamente, outros sítios arqueológicos foram identificados nos municípios do litoral Norte, principalmente no âmbito da Arqueologia Preventiva por meio de projetos devotados ao licenciamento de empreendimentos diversos, quanto às identificações resultantes de trabalhos acadêmicos e projetos de pesquisa, no entanto, a dificuldade de acesso a esse tipo de informações não permite uma caracterização, muitas vezes, mais próxima à realidade arqueológica para os municípios em tela.

\subsection{Comunidades Quilombolas}

Apesar da presença de referências culturais com herança africana nos quatro municípios do litoral Norte paulista, até o momento apenas no município de Ubatuba os grupos afrodescendentes estão buscando seu reconhecimento legal como remanescentes ${ }^{95}$ de comunidades quilombolas. Como apresentado anteriormente (item 3.1.3.), as manifestações deixadas pelos africanos e africanas que aqui chegaram, apesar de terem sofrido modificações ao longo do tempo continuam acontecendo. Embora a Constituição Brasileira de 1988 em seu Art. 68, assegure os direitos a essas comunidades, o caminho até que isso aconteça é longo.

\footnotetext{
95 Segundo Arruti (1997), "o emprego do termo "remanescente" no texto legal pode ser visto como uma maneira de abordar a relação tensa entre continuidade e descontinuidade histórica com o passado. Nota-se, contudo, que a expressão possui caráter ambivalente: "remanescente" pode representar, por um lado, o "resto" ou a "sobra", descaracterizada e empobrecida de formas antepassadas; e, por outro, enfatizar o caráter de resistência cultural e política que proporciona, no atual contexto, possibilidades territoriais, a retomada de valores culturais perdidos e um retorno positivo às formas tradicionais" (Op. Cit. 1997 apud ANDRADE, 2007:11-12).
} 
O primeiro passo é o auto reconhecimento e isso se dá quando a comunidade se organiza e procura a Fundação Cultural Palmares (FCP) que emite o certificado. A FCP é uma entidade vinculada ao Ministério da Cultura (MinC) e responsável, entre outras atribuições, pela formalização da existência dessas comunidades,

\footnotetext{
(...) visando à proteção do patrimônio material e imaterial dos negros quilombolas, realiza a certificação de áreas quilombolas - documento expedido pela Fundação após receber um pedido das comunidades, se autoreconhecendo como remanescentes de quilombos. Esse autoreconhecimento é elemento obrigatório para a conquista do título coletivo das terras que ocupam (MARCATO e BELTRAMI, 2015:2).
}

No caso das comunidades no estado de São Paulo, após a certificação emitida pela FCP, se inicia um processo no ITESP - Fundação Instituto de Terras do Estado de São Paulo, que fomentará a elaboração de um laudo antropológico que irá compor um Relatório Técnico-Científico (RTC), a fim de avaliar se o grupo populacional requerente constitui-se realmente como remanescente de comunidade de quilombo. Dependendo de quem for a posse das terras onde a comunidade está assentada, o próprio ITESP dá prosseguimento ao processo ou o processo pode seguir o INCRA.

Caso o processo siga para o INCRA, o caminho se inicia com a elaboração de um Relatório Técnico de Identificação e Delimitação (RTID), que objetiva aferir os limites das terras ocupadas pela comunidade, por meio de trabalhos de campo, além de consulta a instituições públicas e privadas. Com a conclusão do RTID, faz-se necessário sua publicação e subsequente portaria de reconhecimento no Diário Oficial de União. Caso haja na terra delimitada a presença de imóveis privados, se dará a desapropriação e reembolso aos proprietários, sendo que o passo final virá com a Titulação da terra a comunidade em nome de uma associação legalmente constituída.

De acordo com Borelli (2012), os processos constitutivos destas comunidades seguiram distintas formas, que vão desde a ocupação de terras isoladas, do assentamento em terras que já cultivavam em grandes propriedades, até a compra de outras terras. Na teoria parece que não é muito complicado, mas na prática o caminho revela-se moroso.

Até 0 presente momento, as comunidades quilombolas em processos de regularização estão em estágios diversos que objetivam a demarcação e titulação das terras. Na tabela abaixo (tabela 3), são apresentadas as comunidades quilombolas de Ubatuba e seu respectivo status do processo no ITESP. 
Tabela 3. Remanescentes de comunidades quilombolas de Ubatuba (Fonte: ITESP, 2016).

\begin{tabular}{|l|l|l|}
\hline \multicolumn{1}{|c|}{$\begin{array}{c}\text { Comunidades } \\
\text { Quilombolas }\end{array}$} & Município & \multicolumn{1}{|c|}{ Status do processo de regularização } \\
\hline Camburi & Ubatuba & Reconhecida \\
\hline Fazenda Picinguaba ${ }^{97}$ & Ubatuba & $\begin{array}{l}\text { Em fase de reconhecimento cujos estudos } \\
\text { estão finalizados, aguardando definição de } \\
\text { área }\end{array}$ \\
\hline Sertão de Itamambuca & Ubatuba & Reconhecida \\
\hline Caçandoca & Ubatuba & Reconhecida \\
\hline
\end{tabular}

Nesse sentido, conforme apontado anteriormente, parte das informações apresentadas a seguir para as comunidades quilombolas foram extraídas dos relatórios técnicos científicos (RTC), além de trabalhos acadêmicos e, em algumas comunidades, da informação oral colhida durante as etapas de campo ${ }^{98}$.

As moradias da comunidade do Quilombo do Sertão do Itamambuca estão espalhadas por uma grande área. No entanto, na etapa de campo realizada em 2014 eu não consegui localizar nenhuma moradia a qual moradores confirmassem que ela fazia parte do Quilombo. Posteriormente, em informações obtidas no ITESP, consegui a confirmação que eu tinha estado nas casas que formam a comunidade quilombola, no entanto, pelo fato de uma primeira visita, os moradores não se sentiram confiantes para responder minhas perguntas. Precisaria de mais visitas para estabelecer laços que possibilitassem a compartilhamento das informações. Da mesma fora, as demais comunidades foram alvo de visitas e objetivaram, num primeiro momento, a obtenção de informações relativas aos desembarques de africanos na região. No entanto, compactuo com Ferreira (2009b) quando aponta sobre a importância da "incorporação das comunidades nos processos de interpretação arqueológica" e nesse sentido, essas visitas buscaram a inserção das comunidades na construção das narrativas adotadas quanto a memória sobre os locais de desembarques de africanos ocorrida na região. Ainda que tímida, a participação dessas comunidades foi extremamente importante e alguns dos caminhos aqui apresentados foram construídos por meio dessa interlocução.

\footnotetext{
${ }^{96}$ Com variações na grafia entre os órgãos envolvidos no processo de regulamentação, ao longo desse trabalho vou me utilizar dos nomes que constam nos processos em andamento no ITESP.

97 Em 1951, a Fazenda Picinguaba foi hipotecada pela Caixa Econômica do Estado de São Paulo e esse domínio perdurou até 1974, por isso, a Fazenda Picinguaba também é conhecida como Fazenda da Caixa.

98 Foram realizadas duas etapas de campo com visitas a comunidades quilombolas, a primeira em novembro de 2014 e a segunda em maio de 2015. Apesar das investidas, não foi possível estabelecer diálogos com moradores de todas as comunidades, conforme será apontado mais a diante.
} 
De uma maneira geral as comunidades quilombolas de Ubatuba vêm enfrentando sérios problemas por causa da ocupação das terras, o que acaba gerando um clima constante de tensão, pois, de acordo com Santos (2008), "os maiores entraves enfrentados pelos quilombolas de Ubatuba é a especulação imobiliária e a valorização da região a partir de loteamentos fechados para alojar a classe média" (SANTOS, 2008:4).

Na figura 6, as comunidades quilombolas são alocadas no município de Ubatuba e sumariamente apresentadas adiante, conforme sua distribuição no município no sentido norte-sul ${ }^{99}$.

99 Localmente é considerado como praias do Norte aquelas que estão dispostas a partir do núcleo urbano de Ubatuba sentido Paraty-RJ e consideradas praias do Sul as que estão localizadas entre o núcleo urbano e o município de Caraguatatuba. 


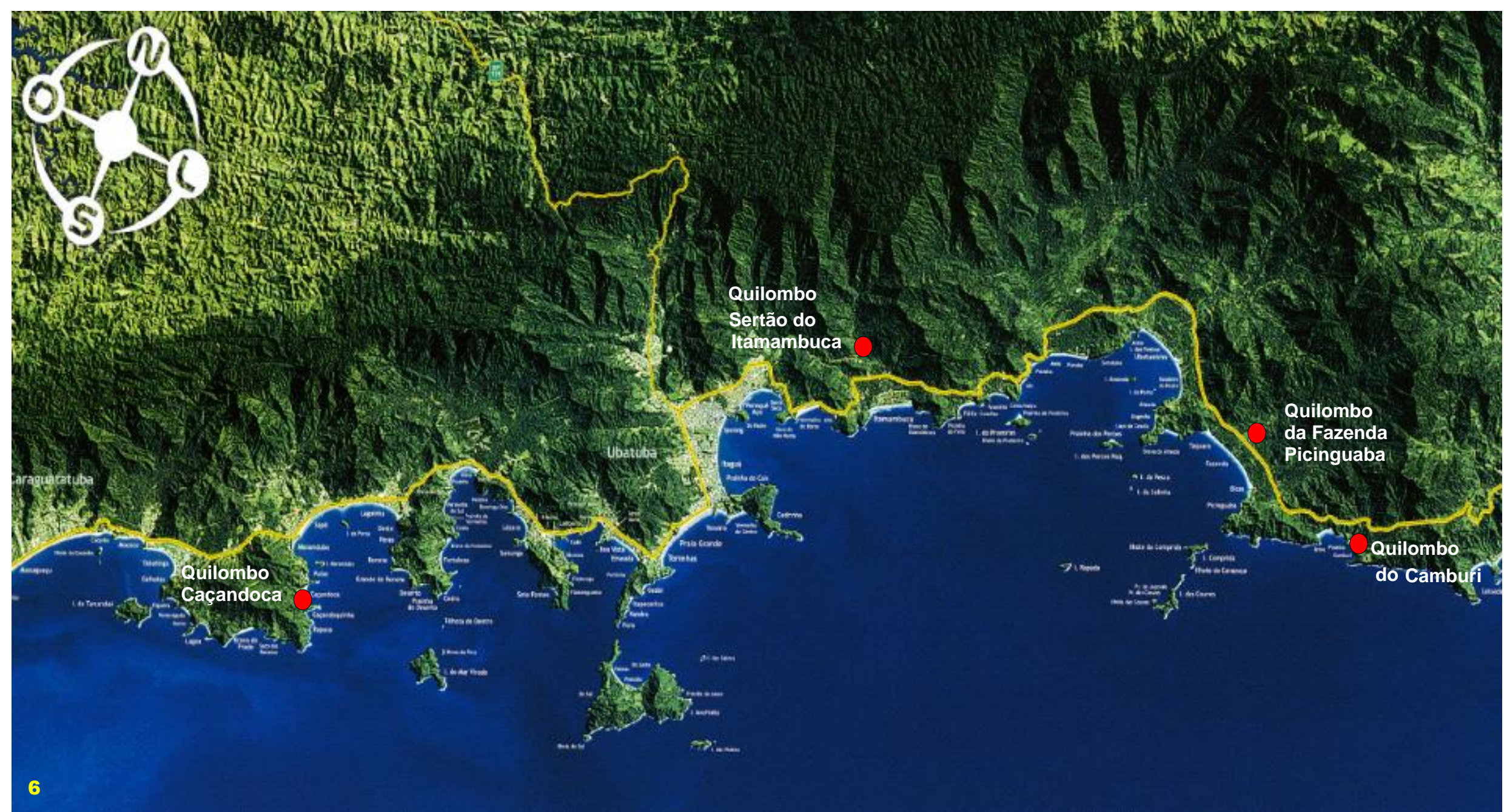

Figura 6. Comunidades quilombolas no município de Ubatuba (Fonte: SATMAPS, imagem de Satélite Landsat 7 - Engesat, adaptação: a autora, 2016). 


\subsubsection{Comunidade do Quilombo Camburito0}

A comunidade do Quilombo Camburi está localizada a Norte do núcleo urbano de Ubatuba e integralmente dentro dos limites do Parque Estadual da Serra do Mar e parcialmente nos limites do Parque Nacional da Serra da Bocaina (SANTOS, 2013) (Prancha 2 e 3).

De acordo com Paula (2002), em levantamento feito para a elaboração do RTC no ano de 2002, aproximadamente 230 pessoas, distribuídas por 50 famílias compunham a comunidade. Ainda de acordo com o autor,

(...) essa comunidade tradicional e diferenciada apresenta em sua formação inicial (em termos territoriais e étnicos), ainda no século XVIII, elementos históricos e de parentesco que tornam incontestável sua categorização atual enquanto uma comunidade de remanescente de quilombos (PAULA, 2002:5).

A concentração das moradias não está na praia homônima, mas ocupa uma localidade adjacente, conhecida localmente como Jambeiro ${ }^{101}$ que fica às margens do rio do Cedro, sendo que esse rio intercepta uma parte do território atualmente pleiteado pela comunidade.

As terras hoje requeridas pela comunidade, de acordo com informações obtidas no site da Comissão Pró-Índio de São Paulo102, pertenciam a "Fazenda Cambory", sendo que essa fazenda não fugia ao padrão das outras fazendas do litoral Norte dessa época (séculos XVIII e XIX): grandes propriedades que tiveram, inicialmente, engenhos de açúcar e aguardente e, em seguida, produziram café para exportação com uso de mão-de-obra escrava. E, a partir da metade do século XIX, entraram em declínio, sendo suas terras desmembradas, doadas, vendidas ou até mesmo abandonadas.

De acordo com Paula,

O primeiro passo na direção de um possível reconhecimento do bairro do Camburi como um território constituído atualmente por remanescentes de

\footnotetext{
100 O nome da comunidade pode ser grafado como Cambury (FCP, INCRA) ou Camburi (ITESP), sendo que será utilizado no presente trabalho a grafia Camburi, que é como a comunidade se identifica.

101 De acordo com Branco (2007: 17), "maior parte das pessoas da comunidade do quilombo do Camburi reside no Jambeiro, localizada no baixo rio, parte mais plana do território e próxima da praia, com maior facilidade de habitação. Na parte íngreme, encontramos algumas residências em pontos dispersos".

102 Desde 1978 em atividade, a Comissão Pró-Índio de São Paulo vem atuando também atua no monitoramento dos processos de titulação das comunidades quilombolas do estado. Informações disponíveis em http://www.cpisp.org.br/comunidades/html/brasil/sp/litoral norte/camburi/camburi historia.html acessado em 19 de outubro de 2016
} 
comunidades de quilombos foi dado em 1996, quando assessores da Prefeitura Municipal de Ubatuba ${ }^{103}$ levaram ao conhecimento de algumas lideranças locais o direito proposto no artigo 68 do Ato das Disposições Constitucionais Transitórias da Constituição Federal de 1988 (PAULA, 2002:5).

Da mesma forma que a abertura das estradas interligando os municípios no litoral Norte foram importantes para o desenvolvimento econômico, diversos problemas também surgiram com a abertura desses acessos. A comunidade quilombola estava relativamente isolada até a década de 1970, quando acontecimentos começaram a ameaçar sua permanência nas terras e provocou mudanças no seu modo de vida. Sendo que

(...) por um lado, houve a construção da BR 101 que atraiu para a região grileiros, especuladores e empresas que usaram de todo tipo de violência e subterfúgios para expulsar as comunidades tradicionais da região, como as do Quilombos do Camburi (...) (COMISSÃO PRÓ-ÍNDIO DE SÃO PAULO, acessado em 19 de outubro de 2016).

Desde então, a comunidade vem vivenciando momentos de incerteza e tensão, visto os processos em curso que tentam remove-la do local. Mais recentemente, em 2013, um grande mal-estar foi gerado com a tentativa de uma reintegração de posse $^{104}$, que de última hora não se concretizou, mas chegou a contar com a presença de um oficial de justiça estadual.

Dessa forma, na etapa de campo realizada em 2014, eu consegui conversar com algumas pessoas informalmente, mas, pelo fato de uma visita pontual, não havia sido possível estabelecer laços de confiança que permitissem a documentação da conversa. Por isso, não foi utilizado o gravador e nem foram feitas imagens das conversas. No entanto, as informações compartilhadas encontram-se diluídas no texto, tendo sido permitido o uso desde que não fosse citada a fonte. A visita a comunidade foi importante no sentido de que mesmo sem a possibilidade de registros, as informações colhidas colaboraram, além de outros pontos, para a construção da memória dos lugares relacionados aos desembarques de africanos escravizados.

\footnotetext{
103 Cumprindo assim com uma das determinações expressas pelo Grupo de Trabalho criado pelo Decreto 40.723, de 21 de março de 1996, e responsável pela pré-identificação de áreas quilombolas em todo território paulista.

104 Outras informações podem ser obtidas no site do Litoral Sustentável. Disponível em http://litoralsustentavel.org.br/noticias/reintegracao-de-posse-na-area-do-quilombo-cambury-pode-ocorrer-aqualquer-momento/ acessado em 19 de outubro de 2016.
} 
Além de que, nas poucas conversas que tive, foi mencionado como um local importante para a comunidade a "toca da Josefa"105".

A localização exata da toca da Josefa é conhecida por muitos dos moradores da comunidade, mas seu acesso é difícil. Não há uma picada aberta e a vegetação é bastante fechada e, de acordo com informações obtidas, está localizada na serra, depois da rodovia.

Apesar de todos os obstáculos, como aponta Paula (2002)

(...) é importante ressaltar que após mais de 50 anos de tentativas voluntárias ou involuntárias de retirar a comunidade do Camburi do seu território tradicional - atualmente e lamentavelmente, cada vez mais dilapidado e fragmentado -, os grupos locais que a compõem continuam a resistir bravamente ao abandono definitivo de suas raízes ancestrais (PAULA, 2002:35).

A fim de divulgar as atividades realizadas no quilombo do Camburi, uma página do facebook está disponível na internet (imagem 22). Vale destacar, que a imagem do perfil da comunidade é de uma visita realizada a Toca da Josefa.

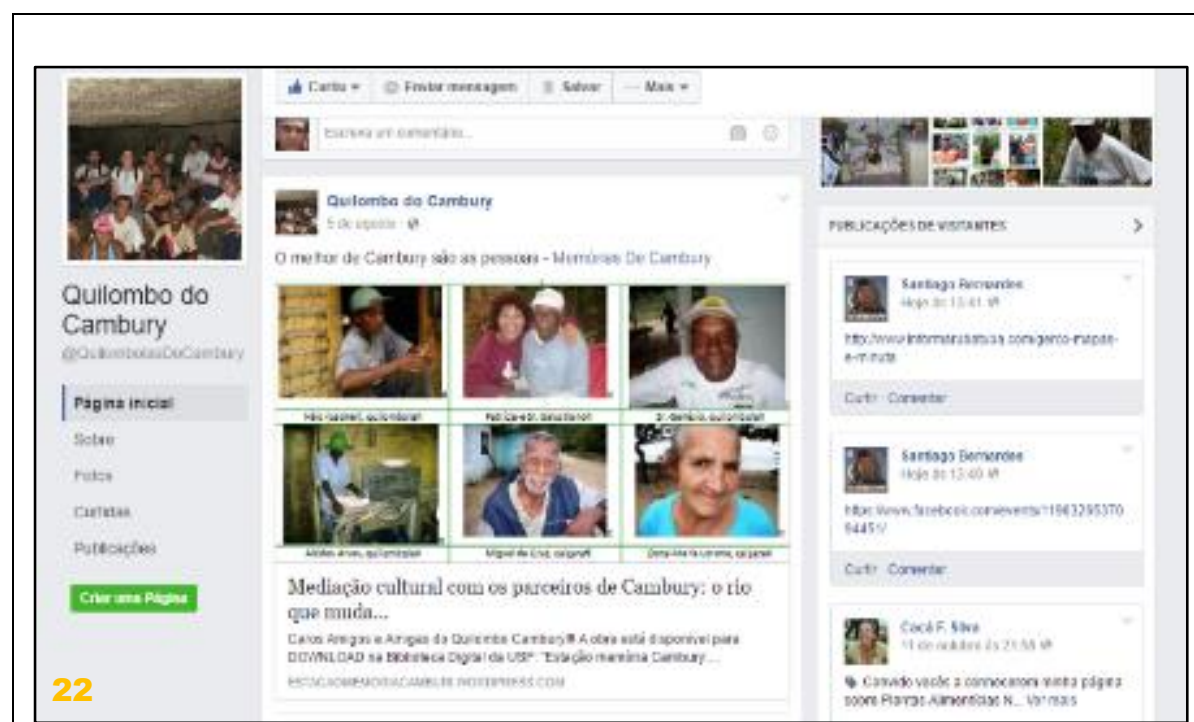

Imagem 22. Página do Facebook mantida pela comunidade do Quilombo Camburi (Disponível em: https://www.facebook.com/QuilombolasDoCambury/?fref=ts acessado em 22 de outubro de 2016).

105 Mansano (1999 apud PAULA, 2002:14) "colheu depoimentos de vários moradores do Camburi que, de modo consensual, assinalaram que um grupo de escravos liderado por uma certa escrava Josefa teria fugido de fazendas localizadas no litoral do município de Paraty no Rio de Janeiro e ocupado parte da região do atual bairro do Camburi por volta do final do século XIX. Esta fase da história da ocupação do Camburi tem uma referência concreta nos dias atuais: a Toca da Josefa". 
A comunidade do Quilombo do Camburi já teve sua certificação emitida pela FCP e o processo atualmente corre no ITESP e no INCRA, já tendo sido reconhecida, aguardando apenas a titulação de suas terras. 


\section{Prancha 2. Quilombo do Camburi}

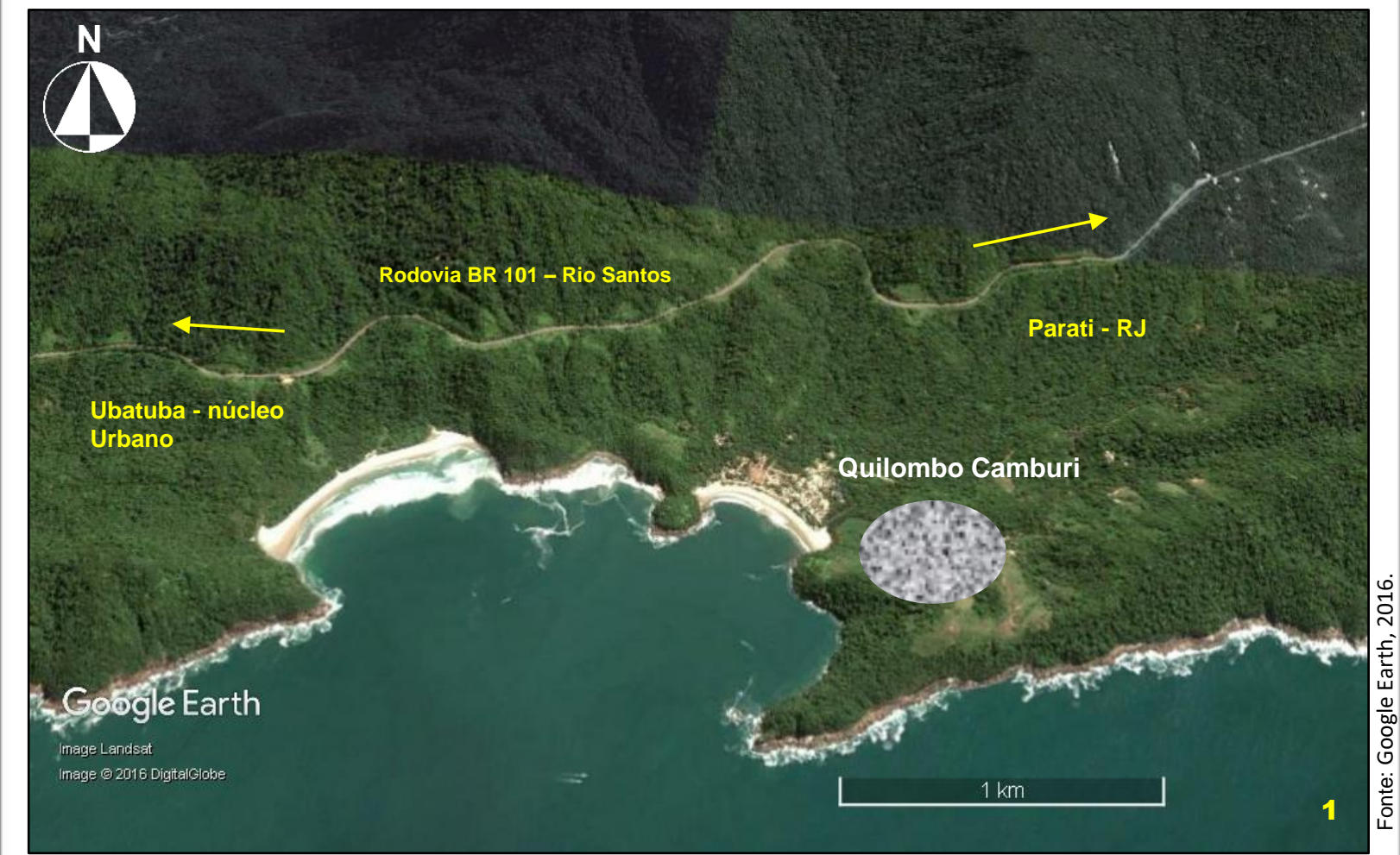

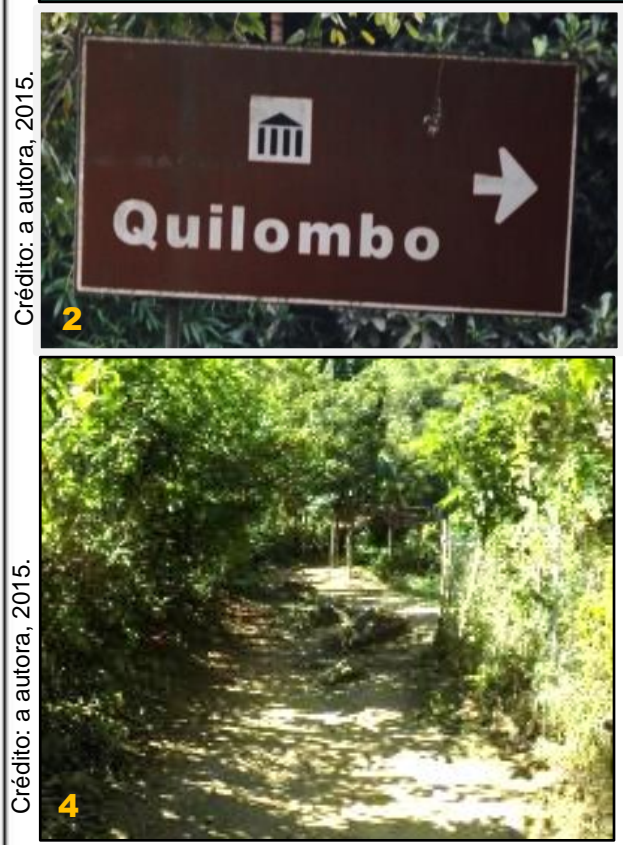

1. Agrupamento principal de casas da comunidade, (não está em escala) indicada na área apenas para fins de situar o leitor;

2. Sinalização na BR 101 indicando a entrada para o quilombo;

3. Placa do ITESP com informações sobre o quilombo;

4. Caminho principal que liga a estrada vicinal a comunidade.

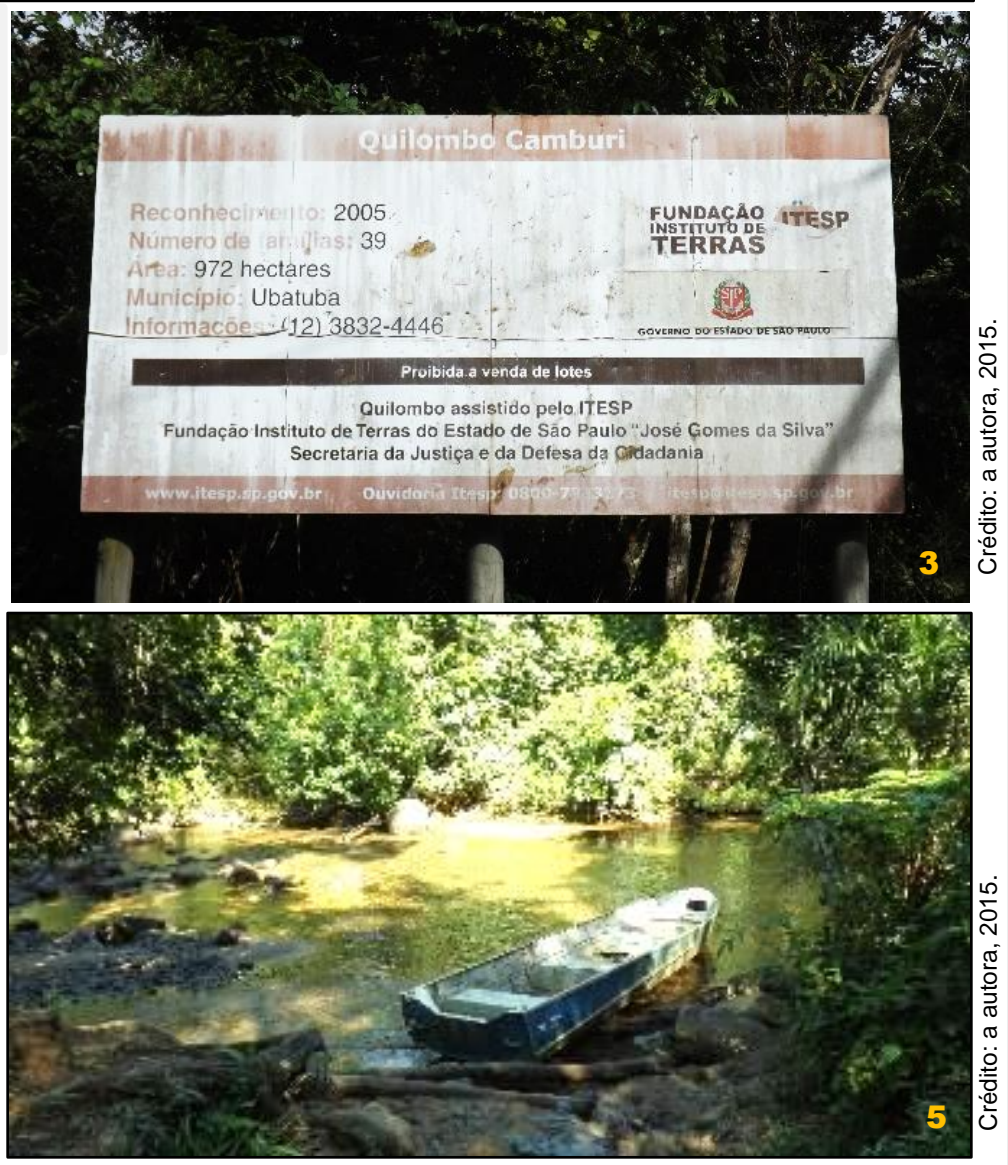

5. Barco aportado as margens do rio Cedro que intercepta a comunidade

Dissertação de Mestrado

A DIÁSPORA NEGRA NO LITORAL NORTE PAULISTA: desafios e possibilidades de uma abordagem arqueológica Aluna: Luciana Bozzo Alves

Orientador: Prof. Dr. Pedro Paulo de Abreu Funari

Museu de Arqueologia e Etnologia / USP 


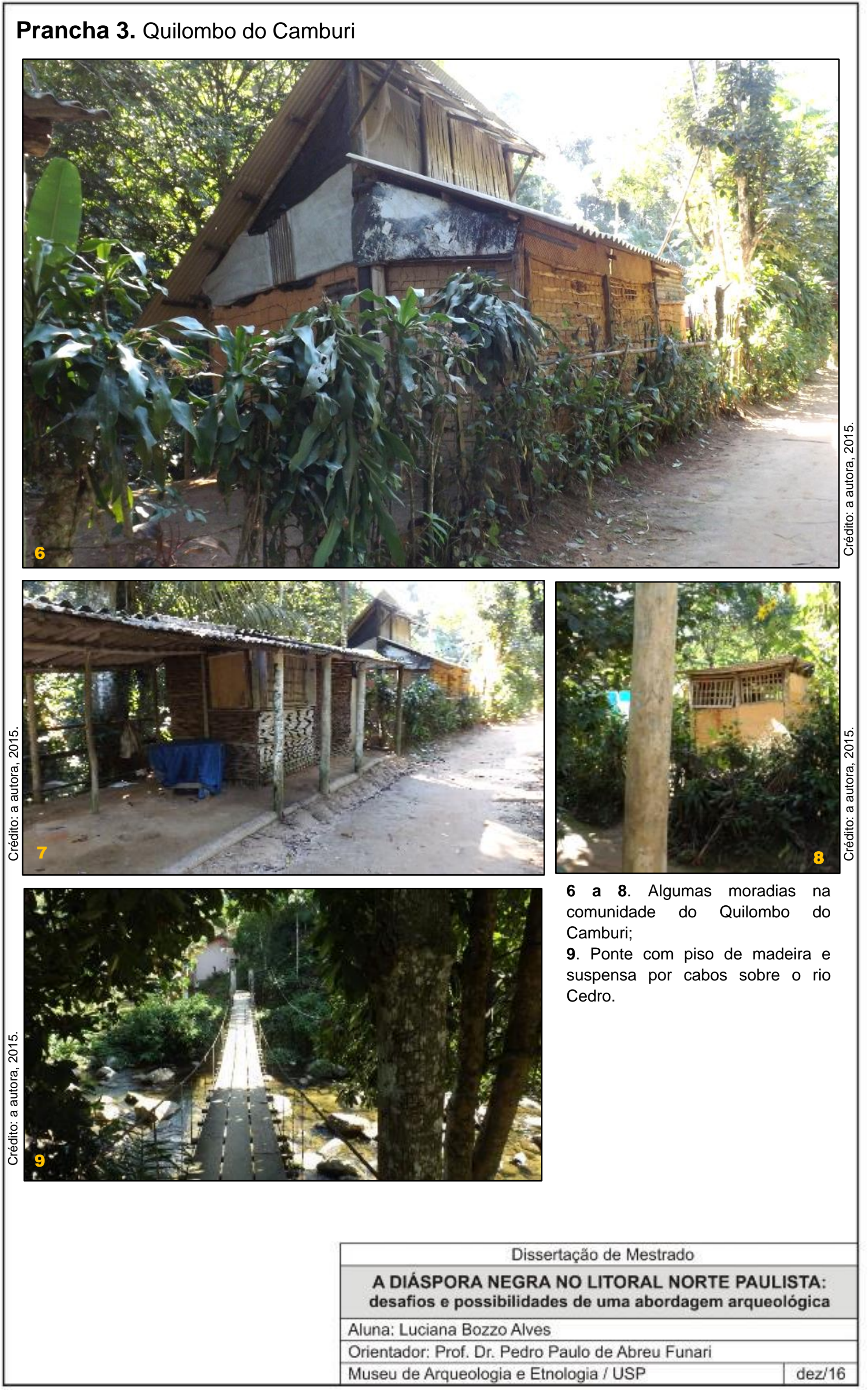




\subsubsection{Comunidade do Quilombo da Fazenda Picinguaba}

O Quilombo da Fazenda Picinguaba, está localizado a Norte do núcleo urbano de Ubatuba, "a meio caminho", pela rodovia Rio-Santos, entre os centros de Ubatuba e Paraty. Na Rio-Santos existe uma placa indicando a "Casa da Farinha" (Prancha 4) e, para quem vem da área urbana de Ubatuba, deve-se entrar a esquerda em uma estrada de terra e percorrer pouco mais de dois quilômetros até chegara a casa de farinha (Prancha 5).

O quilombo da Fazenda Picinguaba está totalmente alocado dentro dos limites do Parque Estadual da Serra do Mar e isso modificou drasticamente a relação dessa comunidade com a terra, e de acordo com Andrade (2007),

(...) se do ponto de vista geográfico e administrativo, a Fazenda Picinguaba está localizada "dentro" do Parque, na ótica dos caiçaras e quilombolas locais é o Parque que está "dentro" de suas terras, contrariando os ritmos próprios de sua "economia rústica" (ANDRADE, 2007:38).

As casas localizadas a partir da rodovia (sentido serra) já fazem parte da comunidade quilombola, pois a área pleiteada incide somente sobre as terras do "sertão 106", não incluindo a faixa litorânea. A comunidade do Quilombo da Fazenda Picinguaba exibe uma marcada sociabilidade comunitária, sendo que as pessoas que lá residem estão ligadas por conexões de parentesco e resistem para manter atividades tradicionais de cultivo e produção de mandioca.

Já discutido anteriormente (item 2.2), a formação de uma comunidade pode se dar de diversas maneiras e, por causa dos benefícios garantidos por lei (mas nem sempre cumpridos), que as comunidades reconhecidas como remanescentes de quilombos têm direitos, os relatórios técnicos científicos procuram mapear as ligações dos atuais moradores com descendência de africanos que vieram ser escravizados na região, a fim de eliminar quaisquer dúvidas. O caso do Quilombo da Fazenda Picinguaba me chamou a atenção nesse sentido, porque o fato do "homem de frente" da comunidade ser uma pessoa que veio de Cunha/SP107, pode acabar gerando certa desconfiança quanto a ocupação e luta por essas terras. Dessa forma, Andrade nos esclarece que essa condição de

\footnotetext{
${ }^{106}$ Localmente são conhecidas como sertão, as áreas localizadas no sentido da serra do mar, tendo como divisória a rodovia Rio-Santos.

${ }^{107}$ O senhor José Vieira, natural de Cunha/SP é a principal figura do Quilombo da Fazenda Picinguaba.
} 
(...) buscar a origem escrava de uma comunidade caiçara tradicional significa perseguir diversos fios da memória genealógica de seus membros e identificar aqueles homens e mulheres negros que viviam nas regiões de intensa circulação de escravos nos ciclos econômicos do período colonial. A reconstituição genealógica das 6 famílias que residem atualmente no território do quilombo indicou haverem raízes escravas em 4 delas. A história ancestral dessas famílias não remonta a uma origem escrava comum. Há diferentes trajetórias genealógicas, que incluem ancestrais de outras regiões, como Paraty, Cunha e Guaratinguetá. A reconstituição genealógica dessas famílias mostra que, embora sejam originariamente distintas, atualmente estão conectadas pelo parentesco e formam uma unidade (ANDRADE, 2007:48, grifo meu).

Como se observa nas palavras de Andrade (2007), a origem escrava comum foi um dos principais pilares que sustentaram a confirmação dessa comunidade como remanescentes de quilombo. De acordo com Andrade, para a elaboração do RTC do Quilombo da Fazenda Picinguaba, muitos encontros foram realizados e, como não podia deixar de ser, os questionamentos acabaram por mexer com a memória dos antigos moradores e possibilitaram a construção de uma identidade étnica relacionada à ancestralidade negra. Apesar das divergências em alguns momentos, o processo de regularização fundiária pleiteado, permitiu a participação efetiva da comunidade nas decisões acerca do território reivindicado (ANDRADE, 2007).

A situação fundiária da Fazenda Picinguaba, da qual o quilombo ocupa uma porção, remete a caminhos complexos, inclusive por meio de um processo hipotecário do antigo proprietário, em meados do século XX, onde a Fazenda passou ao domínio da Caixa Econômica do Estado de São Paulo. Em outubro de 1974, a Caixa doou a área ao Ministério da Marinha, que almejava fazer uma escola naval, no entanto, o projeto não avançou por causa da pouca profundidade da enseada localizada a frente da praia da Fazenda, sendo revertida para a Caixa em julho de 1981. Apesar das terras já terem sido decretadas "áreas de preservação integral”, a própria Caixa "solicitou os serviços da equipe de Resolução de Conflitos de Terras da SUDELPA"108 para fazer o levantamento da situação fundiária. A proposta de desapropriar a Fazenda foi aceita pela Caixa e aconteceu em 1984" (ANDRADE, 2007:36).

No entanto, os entraves ainda existem e, pelo que parece, a resolução ainda terá de percorrer um longo e moroso caminho. Mas, apesar de todas as questões

\footnotetext{
108 Superintendência de Desenvolvimento do Litoral Paulista.
} 
envolvidas no processo de regularização das terras requeridas pela comunidade, esforços têm sido feitos para não cair no esquecimento. Por isso, a comunidade mantém um endereço eletrônico ${ }^{109}$ (Imagem 23), que, apesar de não ter sido atualizado recentemente, proporciona informações básicas a respeito da história da comunidade, assim como também das ações desenvolvidas que visam à valorização e manutenção das manifestações culturais e seu modo de vida. Uma página no facebook foi criada para a divulgação das atividades realizadas pela comunidade (imagem 24).

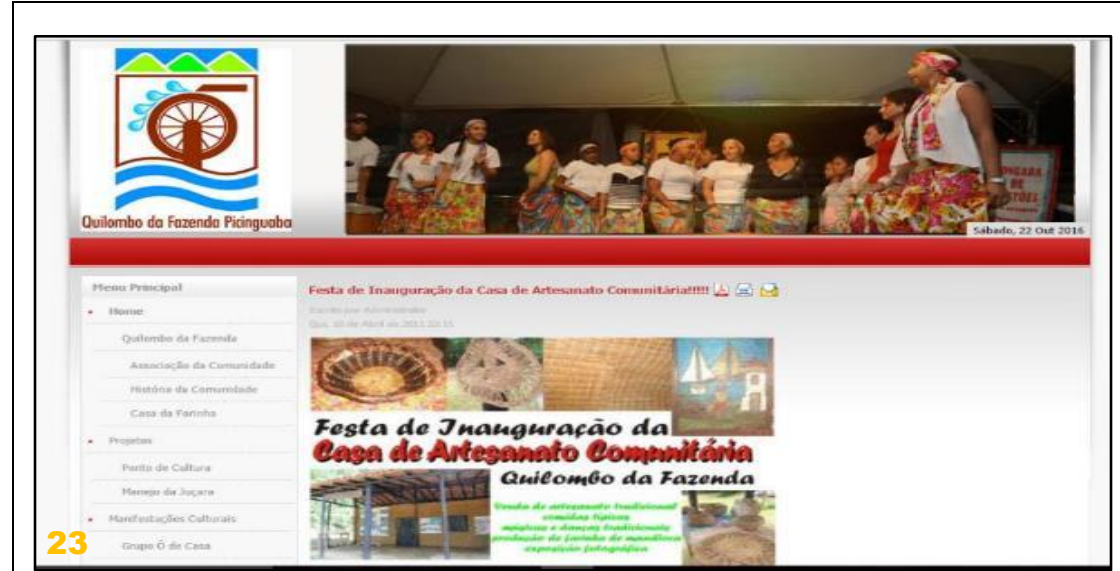

Imagem 23. Página inicial do site do Quilombo da Fazenda (Disponível em: http://quilombodafazenda.org.br/ acessado em 22 de outubro de 2016).

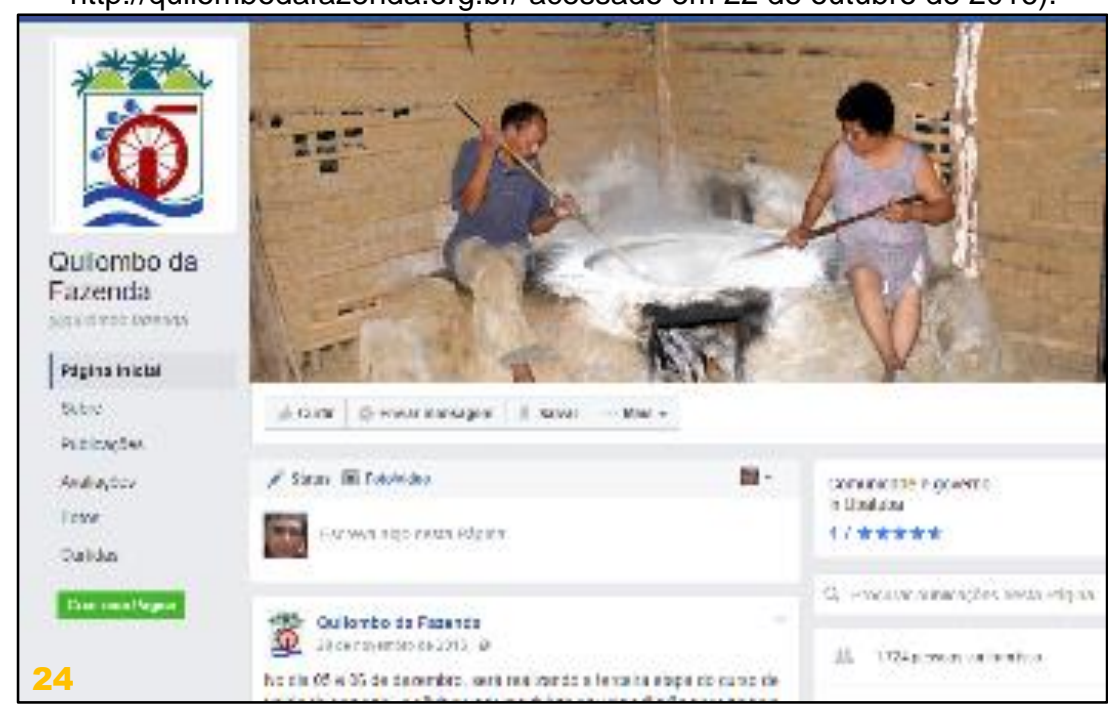

Imagem 24. Página do Facebook mantida pela comunidade do Quilombo da Fazenda Picinguaba (Disponível em: https://www.facebook. com/quilombo.fazenda/?fref=ts acessado em 22 de outubro de 2016).

109 Mais detalhes podem ser obtidos na página oficial do Quilombo da Fazenda Picinguaba. Disponível em. http://quilombodafazenda.org.br/._Acessado em 18 de outubro de 2016. 
Foram realizadas duas visitas a essa comunidade, a primeira aconteceu em novembro de 2014 e a segunda em maio de 2015. A primeira visita objetivou o estabelecimento de contato e o conhecimento da porção central da comunidade, a fim de estabelecer canais que permitiriam uma segunda etapa de campo com objetivos mais definidos.

O contato do quilombo da Fazenda foi estabelecido com o senhor José Vieira, conhecido como "seu Zé Pedro110", importante liderança quilombola que sempre se dispõe a conversar com quem chega para visitar a Casa de Farinha. De acordo com Andrade (2007), a casa de farinha

(...) reformada pelo Parque nos anos 80 tem uma vala de cerca de dois metros de profundidade, onde gira a roda d'água. Zé Pedro sabe que essa vala, feita de pedras grandes, como os calçamentos de Paraty, foi construída pelos escravos. Desde que o interesse de turistas e escolas pelo sertão da Fazenda aumentou, Zé Pedro faz "plantão" na Casa de Farinha para ensinar o processo de fabricação da mandioca, movido pela roda d'água (ANDRADE, 2007 - ANEXO 1).

Nas duas visitas realizadas a comunidade, me encontrei com o senhor José Pedro na casa de Farinha. Na primeira vista, em 27 de novembro de 2014, passamos a tarde toda conversando. Ele me contou um pouco da sua história e de como tinha vindo de Cunha para morar nessa comunidade e da sua luta e de sua gente para se sustentar com dignidade, apesar das restrições impostas com a criação do Parque Estadual da Serra do Mar.

Na segunda etapa de campo, realizada em maio de 2015, cheguei ao Quilombo da Fazenda Picinguaba para conversar com o senhor "Zé Pedro" e, tinha em mãos um pequeno roteiro composto por três perguntas:

1. Qual a história da comunidade?

2. Existem outras histórias sobre lugares, ruínas, entre outros, relacionados a escravidão?

3. O senhor(a) já ouviu falar de algum lugar aqui no litoral Norte onde acontecia o desembarque de africanos escravizados?

\footnotetext{
${ }^{110}$ Figura tradicional da comunidade, teve muito de suas histórias retratadas no livro escrito por Moacir Pinto, em coletânea intitulada. Eu tenho o meu sonho - a sabedoria e os causos do seu Zé Pedro, mestre quilombola da Casa de Farinha de Ubatuba - SP. São Paulo: Editora e distribuidora Suplegraf, 2013.
} 
De uma maneira geral, as respostas dadas tanto pelo seu "Zé Pedro" quanto pelos outros colaboradores que gentilmente aceitaram conversar comigo, estão distribuídas ao longo do presente capítulo e do capítulo 4 e fomentaram alguns dos caminhos aqui intentados ${ }^{111}$.

No quadro abaixo, uma foto do "seu Zé" em 2014 (imagem 25) e a capa do seu livro de causos (imagem 26).
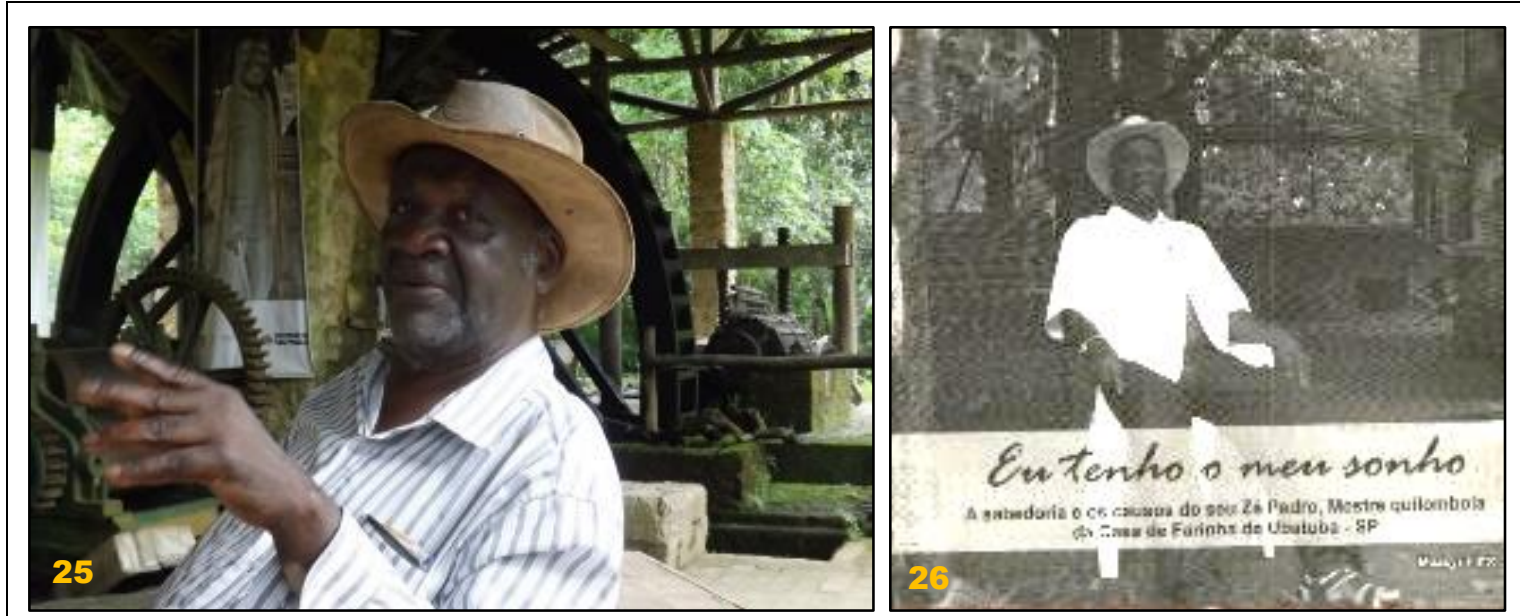

Imagem 25. Seu Zé Pedro, na casa de Farinha no Quilombo da Fazenda Picinguaba (Fonte: a autora, 2014). Imagem 26. Capa do livro de Moacir Pinto que retrata os "causos" de seu Zé Pedro (Fonte: a autora, 2016).

Em março de 2016 foi instituído pelo governo estadual o "Circuito Quilombola Paulista11" que estimula o turismo agroecológico e cultural em sete comunidades remanescentes de Quilombo. Dentre essas comunidades, cinco estão em Eldorado ${ }^{113}$, uma em Cananéia ${ }^{114}$ e duas em Ubatuba, sendo escolhidas como representantes do Ubatuba a Comunidade do Quilombo da Fazenda Picinguaba e o Quilombo da Caçandoca.

\footnotetext{
${ }^{111}$ As mesmas perguntas foram feitas para vários moradores de comunidades tanto de Ubatuba, quanto de São Sebastião e llhabela. No entanto, fiz a opção de não transcrever os diálogos na íntegra na presente dissertação, mas fazer com que as informações obtidas pudessem fomentar alguns dos caminhos propostos. Sempre que for me referir a resposta desses importantes colaboradores, usarei a expressão "informações orais".

112 Desde 2004, a Fundação ITESP (Instituto de Terras do Estado de São Paulo), vinculada à Secretaria da Justiça e da Defesa da Cidadania, desenvolve ações e estimula as comunidades quilombolas para atividades ligadas ao turismo. Com o objetivo de potencializar esse trabalho e colaborar com o incremento da renda das famílias, a Secretaria de Turismo e o ITESP assinaram um convênio para desenvolver projeto de divulgação, capacitação e comercialização do Circuito Quilombola Paulista, com base em roteiros e produtos já existentes, como alimentação tradicional quilombola, hospedagem, passeios em trilhas ecológicas, cachoeiras, cavernas, apresentações culturais e artesanatos.

113 São as Comunidades Pedro Cubas, Pedro Cubas de Cima, São Pedro e André Lopes localizadas no município de Eldorado.

114 A comunidade Mandira de Cananéia.
} 
O Quilombo da Fazenda Picinguaba já recebeu a certificação da Fundação Palmares como sendo uma comunidade remanescente de quilombo e atualmente está em fase de reconhecimento, sendo que os estudos já estão finalizados, aguardando apenas a definição da área. 


\section{Prancha 4. Quilombo da Fazenda Picinguaba}
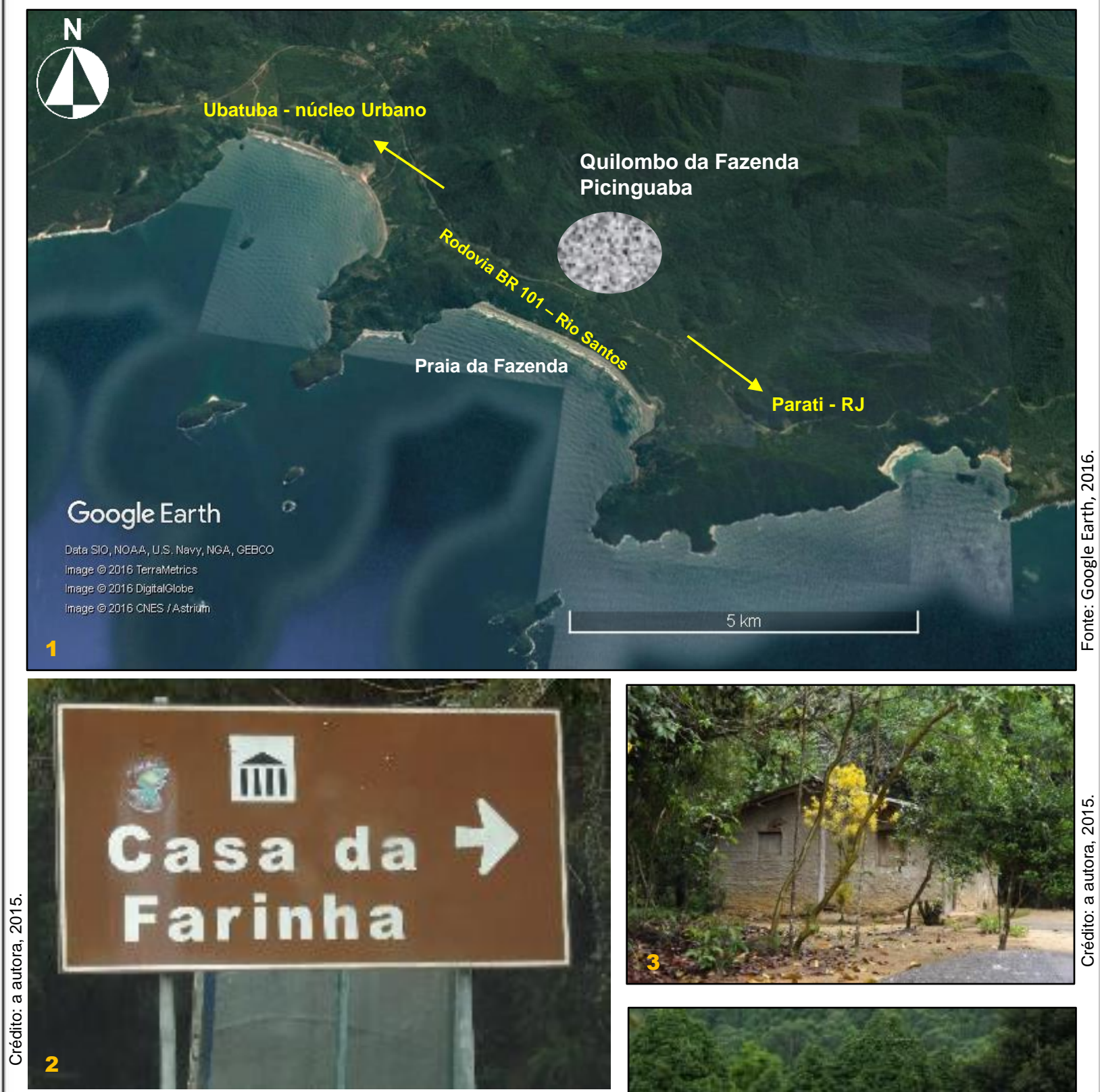

1. Agrupamento principal de casas da comunidade, (não está em escala) indicada na área apenas para fins de situar o leitor;

2. Sinalização as margens da rodovia BR 101;

3 e 4. Primeiras moradias da comunidade, localizadas logo após a entrada na estrada que se inicia na BR 101.
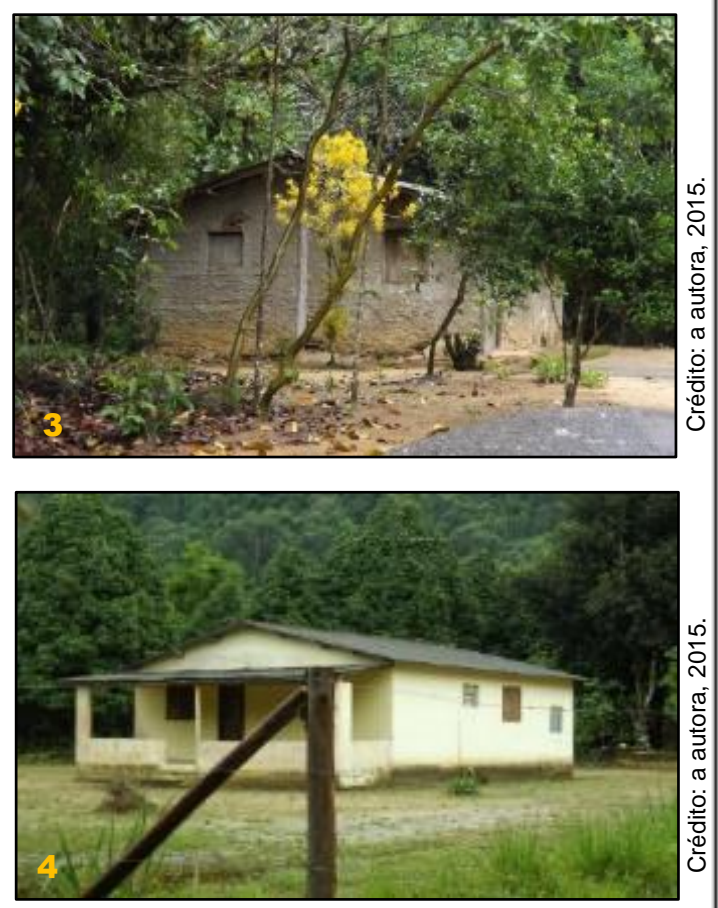

Dissertação de Mestrado

A DIÁSPORA NEGRA NO LITORAL NORTE PAULISTA: desafios e possibilidades de uma abordagem arqueológica 


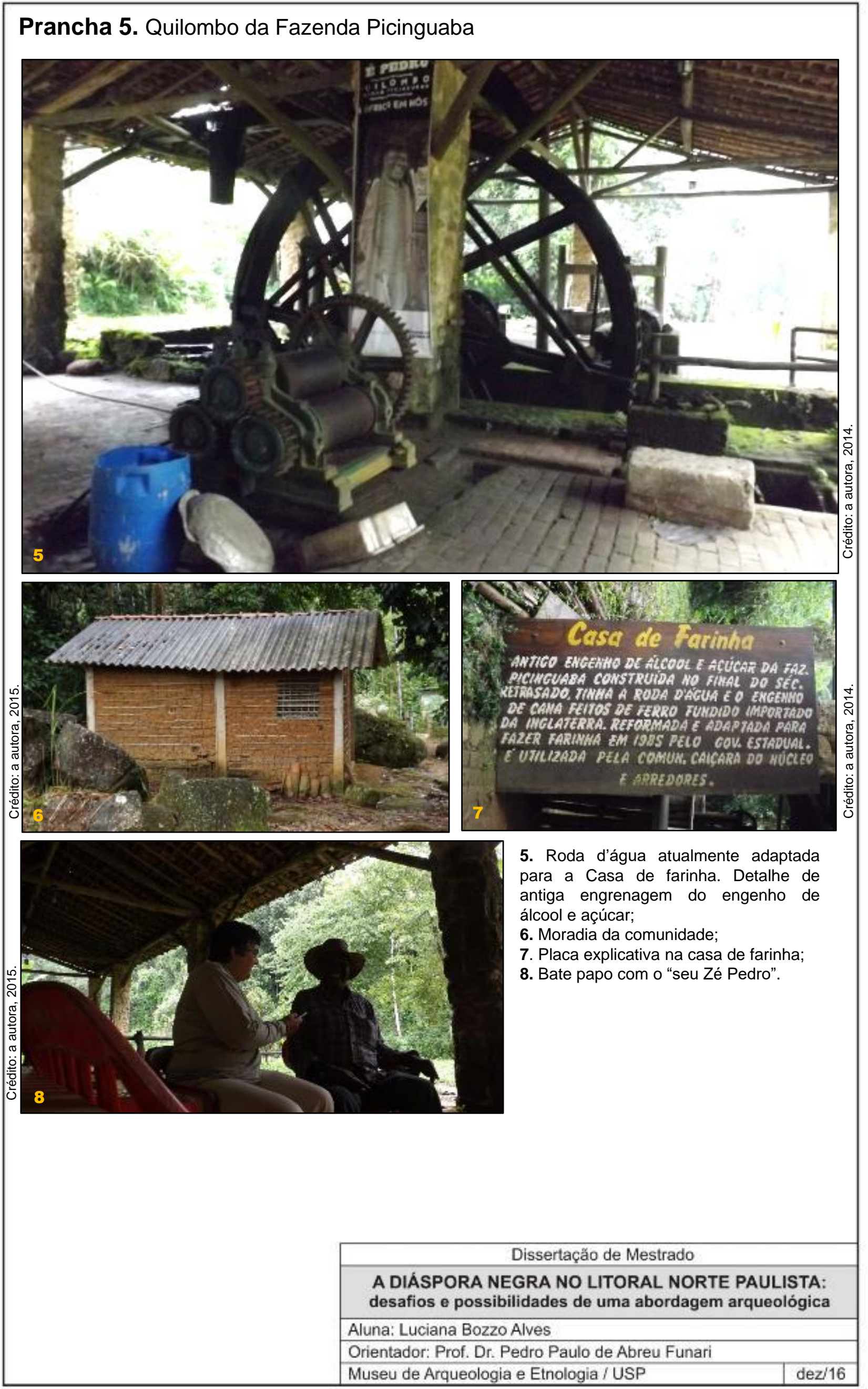




\subsubsection{Comunidade do Quilombo Sertão do Itamambuca'115.}

Para acessar a comunidade do Quilombo do Sertão do Itamambuca, é preciso entrar na estrada municipal da Cazanga, localizada à esquerda da rodovia Rio-Santos (BR-101, sentido Norte), na altura do quilômetro 37 no bairro do Itamambuca (SANTOS, 2008). Na rodovia, para quem vem de Ubatuba é possível visualizar uma placa de identificação do Quilombo fixada pelo ITESP (Prancha 6).

Informações disponíveis na página da FUNDART apontam que atualmente estão distribuídas pelo território aproximadamente 36 casas, que abrigam mais de 100 pessoas, 29 famílias que se reconhecem como descendentes de antigos escravos que trabalhavam nas terras de Modesto Antonio Barbosa ${ }^{116}$ (SANTOS, 2008). Segundo relatos de alguns descendentes dos africanos escravizados que aqui trabalharam, após a abolição, muitos continuaram morando e produzindo nas terras da fazenda, principalmente a mandioca, pois foi o produto que veio substituir o café, para a subsistência do grupo (ANDRADE, 2008).

Com a distribuição das moradias espalhadas por vários caminhos dentro da mata, não fica claro ao visitante quais casas pertencem a comunidade. Ainda assim, depois de percorrer aproximadamente dois quilômetros pela estrada do Cazanga, próximo a algumas moradias, é possível observar ao lado direito da estrada algumas ruínas de grandes construções em pedras sobrepostas, localizadas as margens da estrada, indicadas pelos moradores como possíveis vestígios da antiga sede da fazenda cafeeira de Modesto Barbosa (ANDRADE, 2008) (Prancha 7).

A tensão entre a comunidade e empresas locais tem sido um ponto nevrálgico para a regularização da situação fundiária das terras, principalmente com as donas das duas maiores glebas: a Correias Mercúrio Indústria e Comércio e a Cassanga Administração e Participações.

Além disso, no território reivindicado pela comunidade ainda existem os núcleos congelados que impedem qualquer reforma, ampliação ou construção nos terrenos

\footnotetext{
115 O nome da comunidade aparece como Sertão de Itamambuca, Sertão do Itamambuca e Sertão Itamambuca. Nesse trabalho, vou utilizar Sertão do Itamambuca, que é como está grafado no processo no ITESP.

${ }^{116}$ Modesto Barbosa, segundo a memória dos mais antigos, cultivava café em grande escala, portanto, acreditase que possuía um grande número de escravos.
} 
até que uma solução para as irregularidades seja apresentada. De acordo com informações extraídas do RTC da comunidade do Sertão do Itamambuca, a

(...) Lei de Congelamento de Núcleos Habitacionais Irregulares faz parte de um programa de ações da prefeitura que visa conter, fiscalizar e regularizar a situação fundiária em locais onde o crescimento desordenado e a proliferação de edificações vêm descumprindo a legislação vigente, sobretudo a legislação ambiental (ANDRADE, 2008:37).

Apesar das agruras enfrentadas pela comunidade, ela continua produzindo seu artesanato, participando de eventos relacionados e divulgação da cultura caiçara e quilombola, principalmente pelos integrantes da ARQCSI - Associação dos Remanescentes de Quilombo da Comunidade do Sertão do Itamambuca.

A visita feita a área em 2014 não contou com entrevistas propriamente ditas com os moradores, sendo realizadas apenas conversas informais. Teve inicialmente como objetivo o reconhecimento da área para a próxima etapa de campo, que por questões logísticas acabou não sendo realizada. De qualquer maneira, as conversas realizadas com alguns moradores, colaboraram com a pesquisa. De um modo geral, alguns moradores se mostraram bastantes desconfiados e receosos de dar informações, visto a situação tensa que existe com as empresas situadas na área, conforme citado anteriormente.

A imagem abaixo mostra a página do facebook disponível na internet (imagem 27), com atualizações recentes sobre as atividades realizadas pela comunidade.

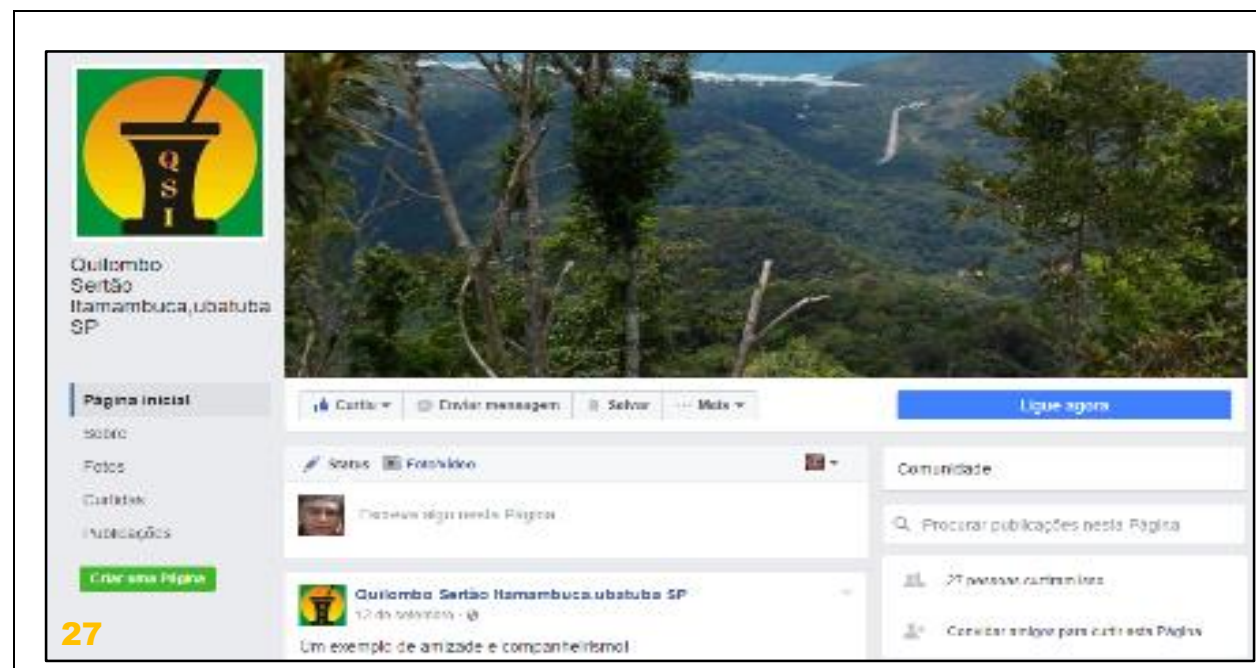

Imagem 27. Página do Facebook do Quilombo do Sertão de Itamambuca (Disponível em https://www.facebook.com/Quilombo-Sert\%C3\%A3o-Itamambucaubatuba-SP$237828813257962 /$ ?fref=ts acessado em 22 de outubro de 2016). 
A comunidade Quilombo Sertão do Itamambuca já teve sua certificação emitida pela FCP e o processo atualmente corre no ITESP e no INCRA, já tendo sido reconhecida, aguardando apenas a titulação de suas terras. 


\section{Prancha 6. Quilombo Sertão do Itamambuca}
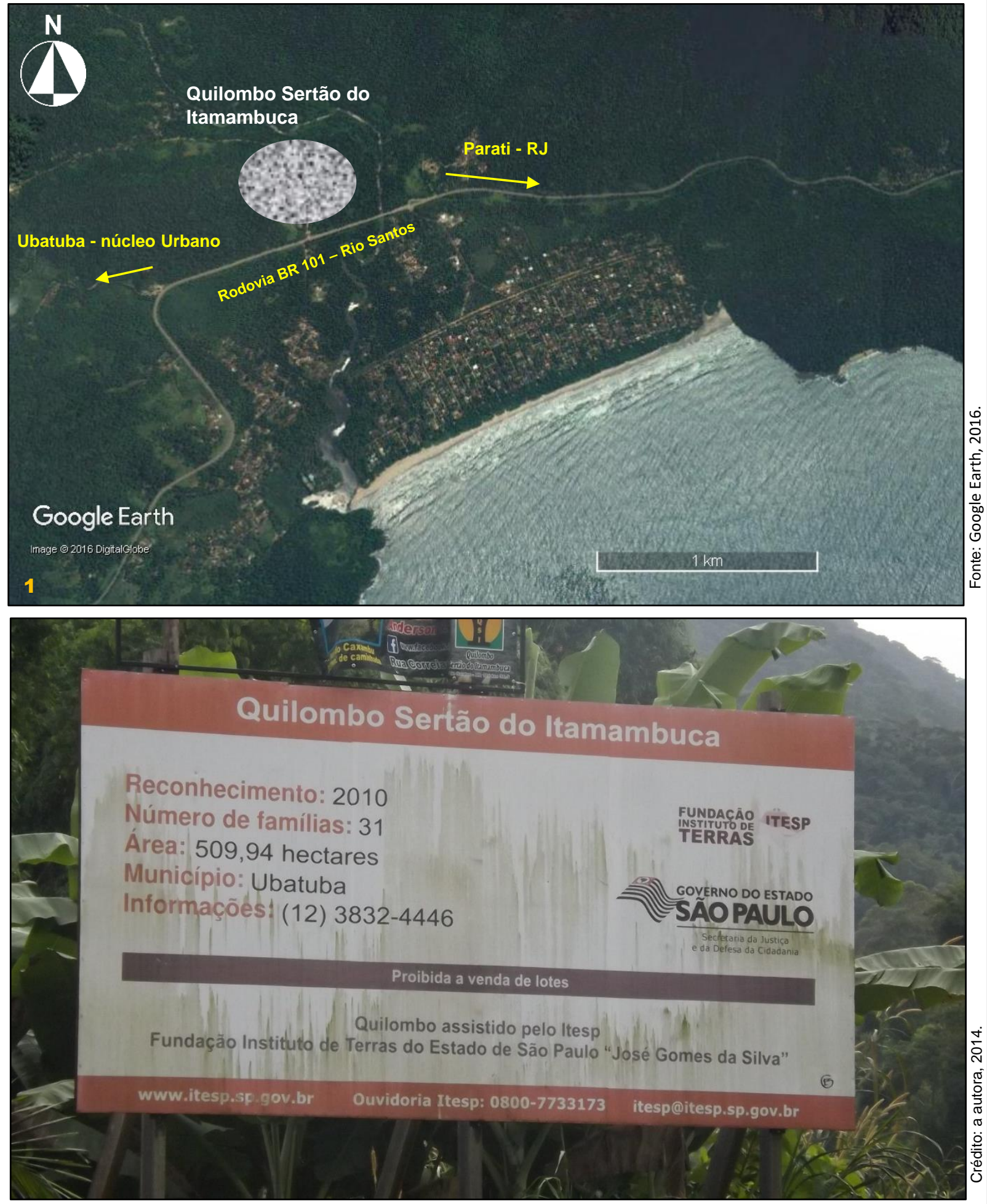

1. Agrupamento principal de casas da comunidade, (não está em escala) indicada na área apenas para fins de situar o leitor;

2. Placa do ITEPS indicando o Quilombo, está localizada as margens da Rodovia Rio-Santos. 


\section{Prancha 7. Quilombo Sertão do Itamambuca}
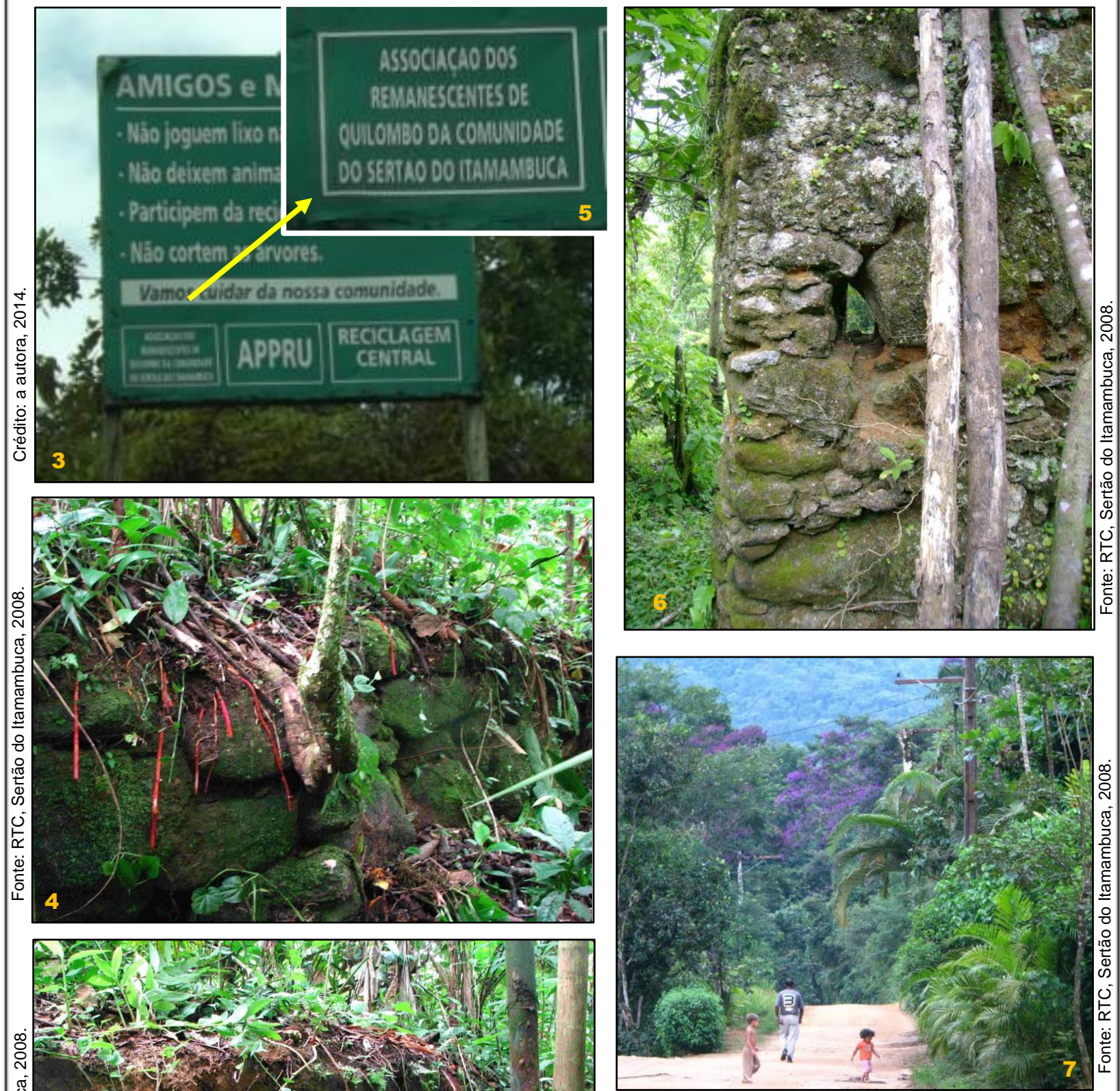

3. Placa de aviso na comunidade e detalhe da identificação da associação de moradores

4 e 5. Antigo muro de pedras (Imagem extraída do Relatório Técnico-Científico - Sertão do Itamambuca (Cazanga), 2008);

6. Ruínas de edificações em pedras sobrepostas, localizadas as margens da estrada da Cazanga, indicadas pelos moradores como possíveis vestígios da antiga sede da fazenda cafeeira de Modesto Barbosa (Imagem extraída do Relatório Técnico-Científico Sertão do Itamambuca (Cazanga), 2008);

7. Estrada da Cazanga, principal acesso a comunidade, pois permite ingresso direto a partir da Rodovia BR 101 - Rio-Santos (Imagem extraída do Relatório Técnico-Científico - Sertão do Itamambuca (Cazanga), 2008);

\section{Dissertação de Mestrado}

A DIÁSPORA NEGRA NO LITORAL NORTE PAULISTA: desafios e possibilidades de uma abordagem arqueológica Aluna: Luciana Bozzo Alves 


\subsubsection{Comunidade do Quilombo Caçandoca ${ }^{117}$}

Localizada a Sul do núcleo urbano de Ubatuba, a comunidade Caçandoca ${ }^{118}$ fica quase na divisa com Caraguatatuba e tem seu acesso feito por uma estrada municipal de terra a partir da BR-101, por aproximadamente quatro quilômetros (Prancha 8 e 9). O território reivindicado pela comunidade tem uma área de aproximadamente 890 hectares ${ }^{119}$ e faz limite a Leste com a orla marítima, ao Sul e Oeste com o divisor de águas da serra de Caçandoca ( $512 \mathrm{~m}$ de altitude) e a Norte com o condomínio da praia do Pulso. Na BR-101 para quem vem de Ubatuba para Caraguatatuba, é possível visualizar uma pequena placa indicando a praia da Caçandoca.

A história da comunidade iniciou-se em 1858, quando o português José Antunes de Sá comprou a Fazenda Caçandoca. Dividida em três núcleos administrativos, abrigavam além da casa sede, um engenho. Na fazenda produzia-se café e aguardente de cana-de-açúcar até o seu desmembramento que aconteceu em 1881. A partir de então, a fazenda Caçandoca foi herdada por filhos e netos legítimos do proprietário, mas nem todos permaneceram nelas. Com relação aos ex-cativos, parte se mudou para outras localidades e outra parte permaneceu na condição de posseiros, com autorização para administrar seu próprio trabalho.

Depois de seu desmembramento em 1881, o café foi paulatinamente substituído pela banana e pela mandioca, sendo que esses itens eram vendidos pelos moradores da Caçandoca até meados da década de 1970 (BRANCO, 2007).

A certificação da FCP veio em 22/07/1998, sendo que nesse mesmo ano o processo de titulação das terras foi iniciado pelo ITESP. Em 2000, o ITESP publicou o relatório técnico-científico reconhecendo a comunidade como remanescentes de comunidades quilombolas e identificando os limites de seu território com 890 hectares.

\footnotetext{
117 A área requerida pela comunidade Caçandoca é extensa e abarca áreas requeridas por outras comunidades, como é o caso da Caçandoquinha, Saco da Bananas, Frade e Raposa. Na FCP, e no INCRA são processos separados, no ITESP fazem parte de um único processo. Minha opção é sempre que me referir a Caçandoca, considerar todas as comunidades abrangidas dentro da área requerida.

118 Importante salientar que "para o grupo quilombola, o termo Caçandoca, atualmente, designa primordialmente a área da praia e do sertão da Caçandoca. O território historicamente ocupado por aquela comunidade quilombola hoje é identificado pelos seus moradores através dos nomes de cada uma das localidades que o compõem: Praia do Pulso, Caçandoca, Caçandoquinha, Bairro Alto, Saco da Raposa, São Lourenço, Saco do Morcego, Saco da Banana, Praia do Simão. Cada um destes lugares sediou um pequeno núcleo de habitações, e estes mantinham intenso relacionamento entre si. Juntos constituíam uma unidade populacional maior, que se identificava por partilhar uma origem e tradições comuns" (SCHMITT, Alessandra. Relatório técnico-científico sobre a comunidade de quilombo da Caçandoca, município de Ubatuba / São Paulo. Junho/2000: 17-18).

119 De acordo com dados obtidos no RTC - ITESP.
} 
Posteriormente, o INCRA abriu processo para regularizar as terras da comunidade e, atualmente a comunidade é reconhecida e aguarda apenas a titulação de suas terras.

A visita a comunidade do quilombo Caçandoca ocorreu em 2014 e em 2015, no entanto, as conversas feitas com algumas pessoas da comunidade tiveram caráter absolutamente informal. Não foram registrados o áudio e nem foram feitas imagens das conversas. Como essa comunidade não constituía objeto específico da pesquisa, não retornei, mas entendo que precisaria de mais etapas de campo para estabelecer uma relação de confiança e assim obter mais informações. De uma forma geral, essa visita foi importante e também colaborou para um entendimento inicial das tensões envolvidas entre o "ser ou não ser quilombola".

Parte dessa tensão, no meu entendimento, tem relação com a entrada de outros grupos familiares localizados dentro da área inicialmente pleiteada pela comunidade Caçandoca, visto os processos em tramitação de Caçandoquinha, Frade, Raposa e Saco das Bananas. Na Fundação Palmares são processos separados, conforme já apontado, e o ITESP considera um processo só. Tanto que a placa que fica na estrada de terra que dá acesso à praia da Caçandoca e intercepta porção do agrupamento de moradias, está com o nome Caçandoca raspado, ficando apenas Quilombo.

Conflitos à parte, o processo de titulação enfrenta a burocracia, que gera longas esperas. A comunidade não pode esperar de braços cruzados e vai resistindo como pode. Da mesma forma que as outras três comunidades quilombolas localizadas no município de Ubatuba, o perfil criado no facebook (imagem 28) também é usado para divulgar as atividades que vem sendo realizadas. E a comunidade de Caçandoca, juntamente com o Quilombo da Fazenda, em 2016 passou a integrar o projeto do governo estadual denominado "Circuito Quilombola Paulista", conforme exposto anteriormente. 


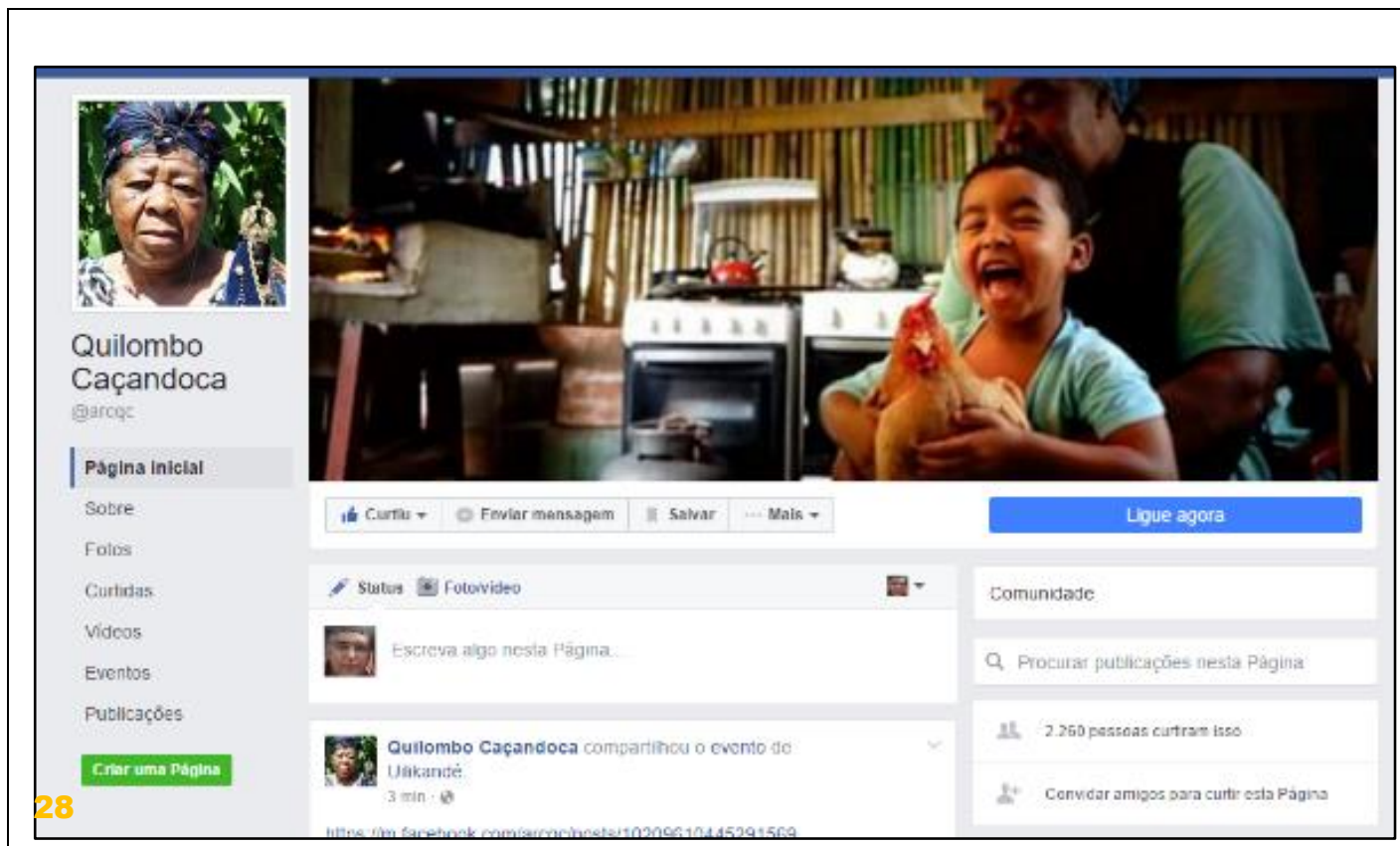

Imagem 28. Página do Quilombo Caçandoca (Disponível em https://www.facebook.com/arcqc/?fref=ts. Acessado em 22 de outubro de 2016).

A comunidade do Quilombo Caçandoca já teve sua certificação emitida pela FCP e o processo atualmente corre no ITESP e no INCRA, já tendo sido reconhecida, aguardando apenas a titulação de suas terras. 


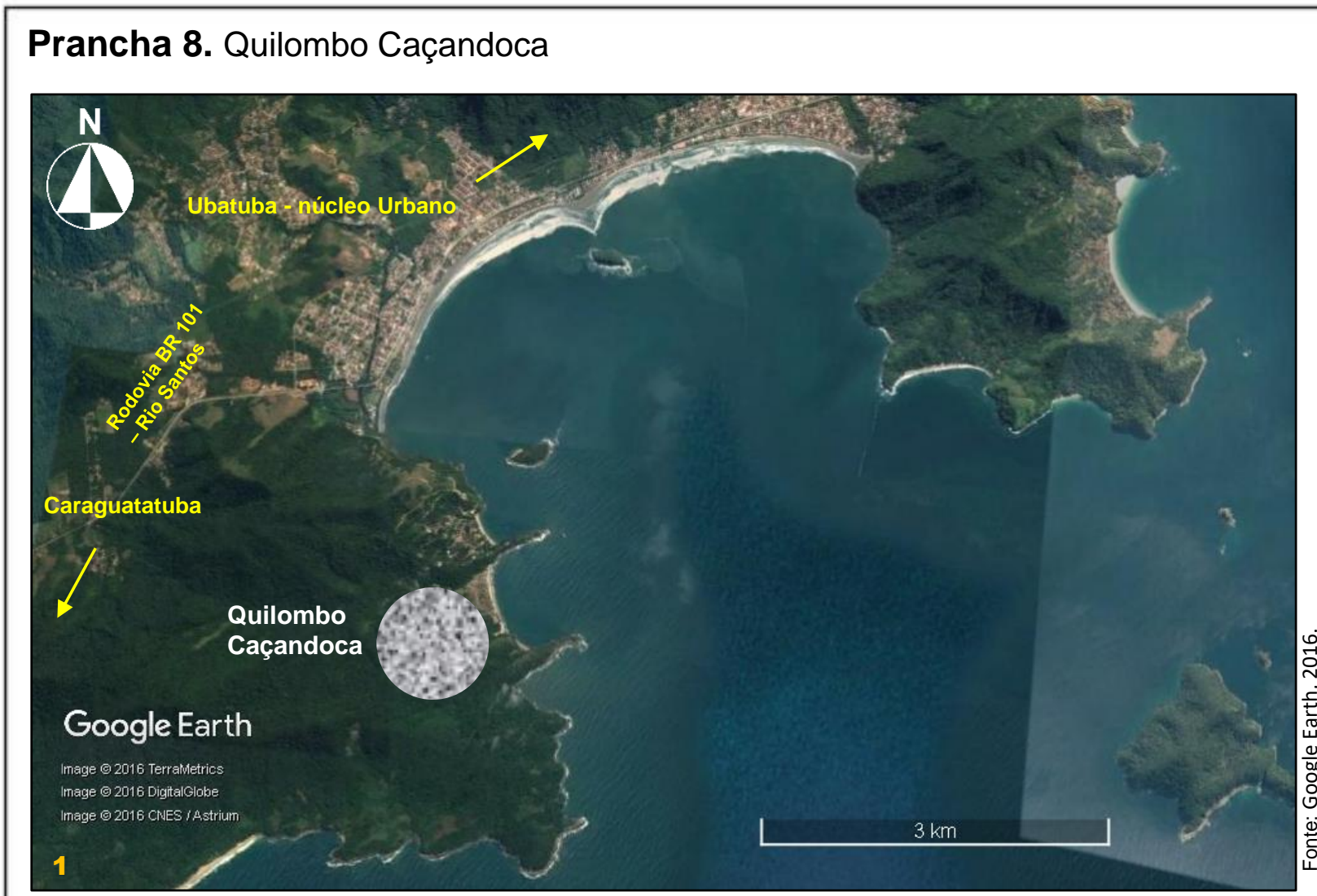

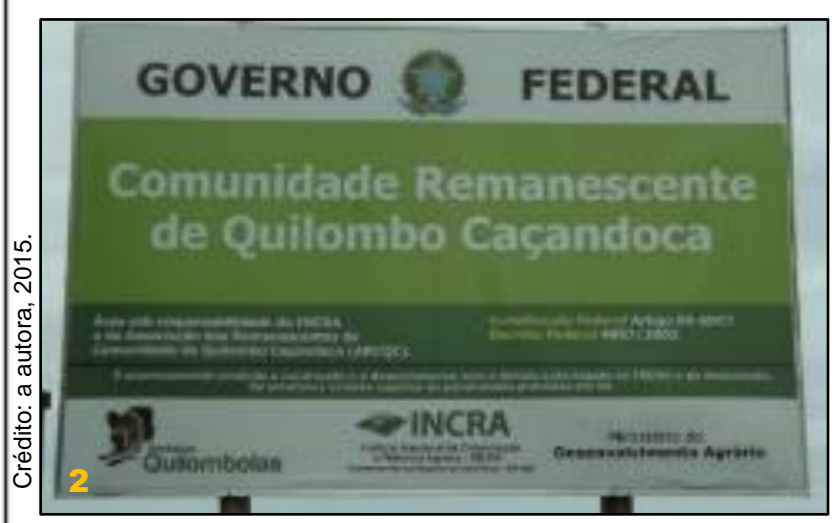

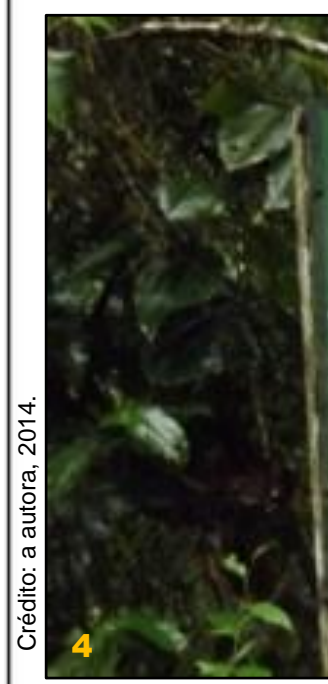
890 HECTARES

ART. 68 DA CONSTITUCHO FEOERAL - hOS emanescentes oas comunioades OE OULONBOS OUE ESTLAN OCURANDO SUAS terass, If RECONHEGIOA

A PROPREDAOE OEFINTINA DEVENDO

- estado entirlutes os TiruLOS RESPECTINOS:
QUILOMBO DA CAÇANDOCA
3

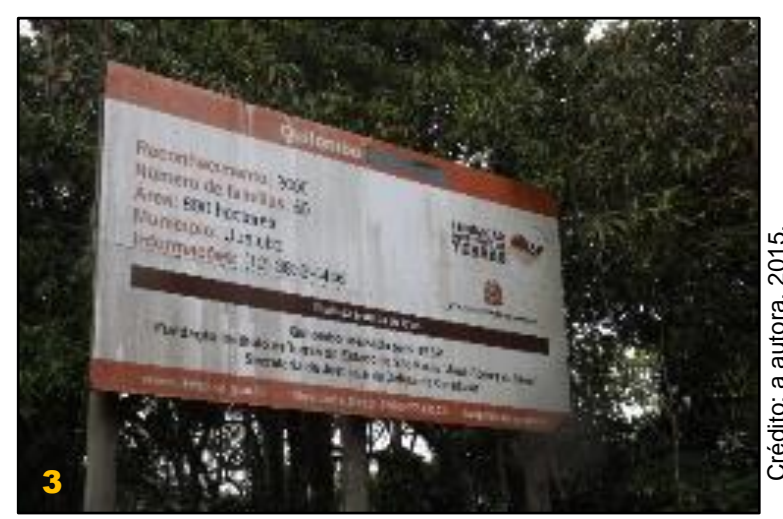

1 Agrupamento principal de casas da comunidade, (não está em escala) indicada na área apenas para fins de situar o leitor;

2 a 4. Sinalização ao longo da estrada que dá acesso a comunidade e a praia da Caçandoca.
Dissertação de Mestrado

A DIÁSPORA NEGRA NO LITORAL NORTE PAULISTA: desafios e possibilidades de uma abordagem arqueológica Aluna: Luciana Bozzo Alves Orientador: Prof. Dr. Pedro Paulo de Abreu Funari Museu de Arqueologia e Etnologia / USP 

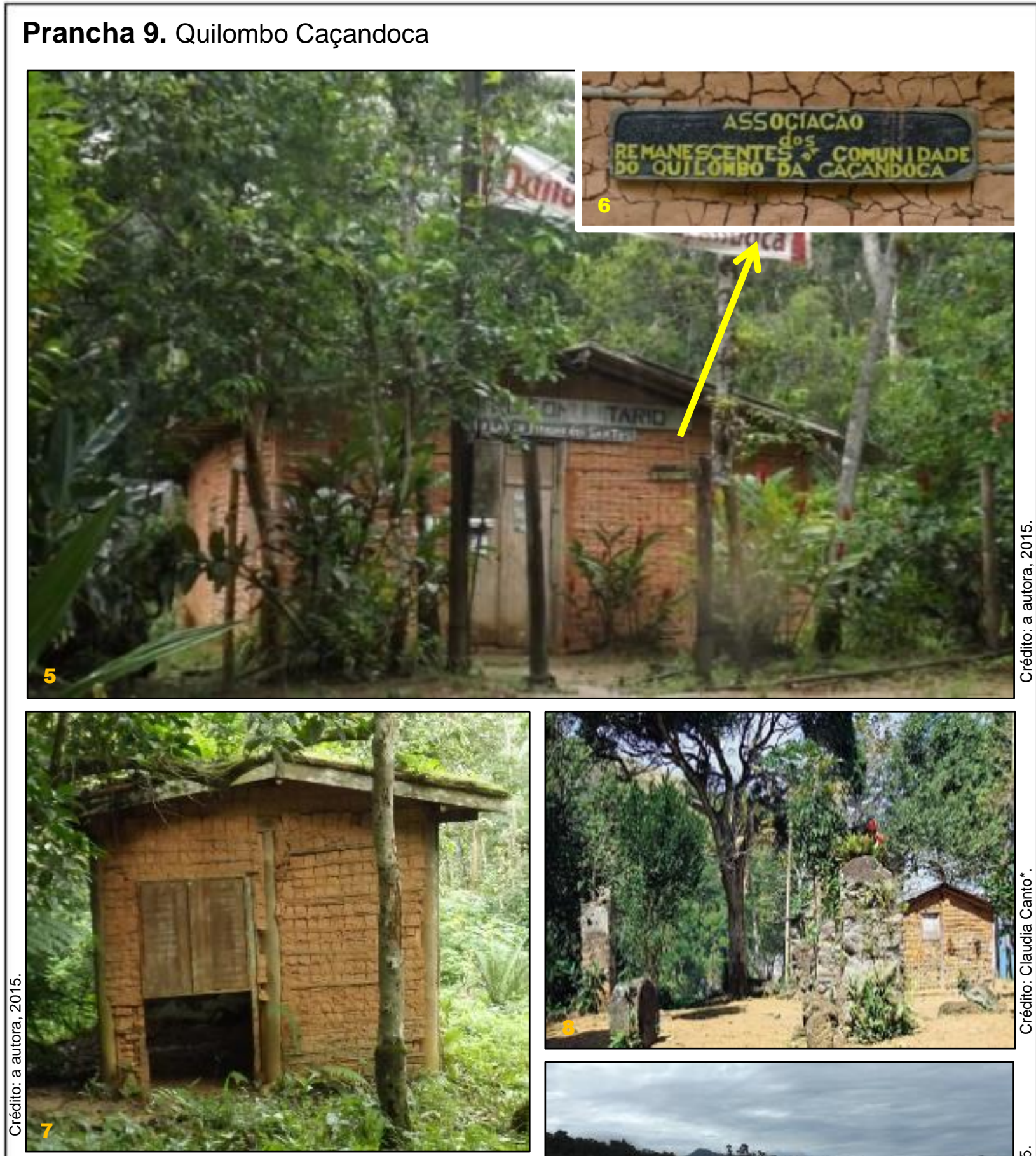

5 e 6. Sede da Associação de moradores;

7. Moradia da comunidade;

8. Ruínas na praia de Caçandoquinha (*disponível em http://racabrasil.uol.com.br/cultura-gente/150/artigo_2055531.asp/);

9. Praia de Caçandoca, vista norte.
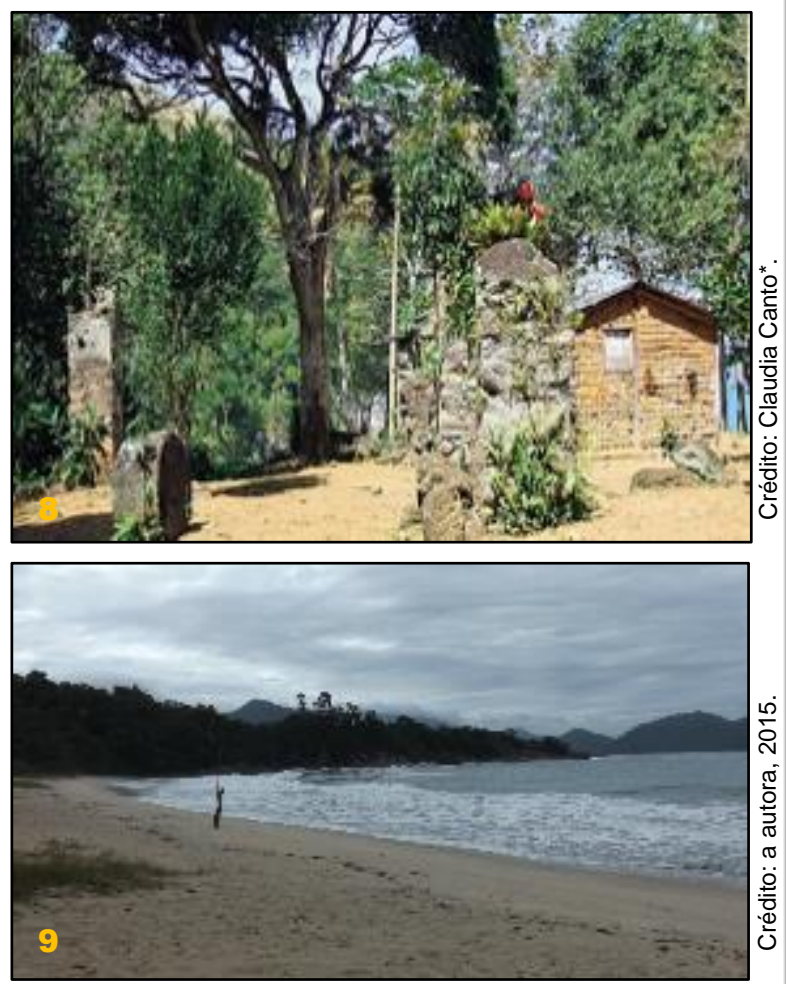

Dissertação de Mestrado

A DIÁSPORA NEGRA NO LITORAL NORTE PAULISTA: desafios e possibilidades de uma abordagem arqueológica

Aluna: Luciana Bozzo Alves

Orientador: Prof. Dr. Pedro Paulo de Abreu Funari

Museu de Arqueologia e Etnologia / USP 


\section{Capítulo 4.}

\section{PAISAGENS dA DiÁSPORA AfRICANA: ACERCA DA (IN)VISIBILIDADE DOS LOCAIS DE} DESEMBARQUE E DE REFÚGIO 
Desde a segunda metade do século XVIII que o comércio de africanos escravizados começou a perder legitimidade no mundo Atlântico, até tornar-se completamente ilegal no início do século XIX, na maior parte dos países ${ }^{120}$ que o praticavam. Esse movimento acabou gerando uma pressão maior ainda no Brasil, sem, é claro, desconsiderar a pressão exercida pelo governo britânico. Por isso, em 7 de novembro de 1831, o governo Imperial brasileiro promulgou a primeira lei proibindo a entrada de africanos escravizados, prevendo, inclusive, severas penas para quem vendesse, transportasse ou comprasse africanos traficados em todo o território brasileiro (MATTOS, et al, 2013:8).

Até a promulgação da lei em 1831, necessariamente todos os desembarques de africanos deveriam acontecer nos portos tradicionais, para fins de controle do Estado e também para a arrecadação de impostos. Apesar disso, conforme apontado anteriormente e, de acordo com Rodrigues (2005), alguns desembarques de africanos aconteceram ao longo do litoral brasileiro, visando burlar do controle do Estado, escapar das altas taxas cobradas e fazer com que a "carga humana" chegasse mais rapidamente ao seu destino. No entanto, com a lei de 1831 em vigor, os desembarques não deveriam mais acontecer em todo o território brasileiro, mas não foi isso que se sucedeu. As viagens do continente africano para o Brasil continuaram acontecendo, no entanto, agora o destino eram as enseadas ermas e as praias distantes dos centros urbanos, que permitiam que os desembarques, considerados agora clandestinos, fossem realizados (RODRIGUES, 2005).

Para a recepção desse contingente de escravizados, novas estruturas precisavam ser edificadas, a fim de atender permitir o restabelecimento dos africanos $^{121}$, que depois de longas viagens encontravam-se severamente debilitados e/ou doentes (PESSOA, 2013).

\footnotetext{
120 Dinamarca, 1803, Inglaterra, 1807, entre outros.

121 Importante salientar que essa questão era meramente comercial, não tendo nada a ver uma preocupação em relação ao bem-estar dos africanos traficados.
} 


\subsection{Olhar a partir dos documentos históricos}

A partir da abolição do comércio negreiro em primeiro de maio de 1807 nas colônias inglesas, o Brasil passa a ser pressionado pelo governo britânico para, inicialmente, proibir o comércio de africanos. Tal pressão passa a ser exercida após favores da marinha britânica a fuga de D. João VI de Portugal, em 1808. Mas, o monarca fazia somente promessas vagas e não se comprometia efetivamente em resolver o problema. A pressão sobre o Brasil - diplomática, econômica, ideológica e militar - iniciou-se com o tratado de 19 de fevereiro de 1810, seguido por outras tentativas em 22 de janeiro de 1815 e 28 de julho de 1817, entre as coroas da Inglaterra e do Brasil, para que o país mostrasse reais intenções visando à proibição do comércio negreiro ${ }^{122}$ (COSTA, 1997). Outra tentativa de acabar com o comércio de africanos foi realizada em 1823 por José Bonifácio de Andrada e Silva, no entanto, os objetivos propostos não foram alcançados. Com a independência do Brasil, as pressões contra o tráfico de africanos continuaram e, em 1826, foi assinado um tratado $^{123} \mathrm{com}$ a Inglaterra. Cinco anos depois, é promulgada, em 7 de novembro de 1831 a Lei Feijó (ROOS, 2007), que, apesar das investidas inglesas, também não foi completamente eficiente ${ }^{124}$ para o banimento do comércio de africanos. Para Costa (1997), a lei de 1831 não surtiu nenhum efeito, como se observa a seguir:

O desenvolvimento da cultura cafeeira fez crescer a demanda de mão-deobra e o contrabando prosseguiu em toda a costa. Os desembarques clandestinos ao longo do litoral contavam com a cumplicidade tácita das populações e as autoridades que intentavam pôr um paradeiro ao contrabando sentiam-se impotentes. No Parlamento choviam representações solicitando a revogação da lei. Ela foi mantida, embora sem nenhuma eficácia. Nem os cruzeiros ingleses, nem as autoridades nacionais conseguiam frustrar a ação dos contrabandistas. Os negros, apesar de juridicamente livres, eram vendidos como escravos. Os interesses ligados à grande lavoura desafiavam a lei. Resistiam à pressão britânica e desrespeitavam as autoridades. Por essas razões o tráfico prosseguiu depois de $1831 \mathrm{com}$ a mesma intensidade e com todo o quadro de horrores que

\footnotetext{
122 (...) o Estado português emitiu dois Alvarás com força de lei regulando a arqueação de escravos: Alvará de 24 de novembro de 1813 e o de 26 de novembro de 1818. Com a adoção dos alvarás, o Estado luso e os mercadores de escravos puderam se organizar e resistir por mais tempo à crescente pressão inglesa para pôr fim ao tráfico de escravos (TAVARES, 2012:76).

123 Segundo Conrad (1985:76), nesse tratado o governo brasileiro se comprometeu a "proscrever a importação de escravos três anos após a ratificação do tratado pelos dois governos, e a partir daquela data o tráfico seria "considerado e tratado como pirataria".

${ }^{124}$ Em 1831 foi promulgada pelo governo imperial a primeira lei que proibia o tráfico de escravos negros no Brasil, tida como letra morta na medida em que não foi respeitada por nenhum dos proprietários rurais. Daí a caracterização formal de —clandestinidadell aos desembarques. O descumprimento da lei acabou cunhando a expressão "para inglês ver".
} 
sempre o caracterizava. Calcula-se que entre os anos de 1840 e 1850 entraram no país, em média, de trinta a quarenta mil negros por ano (COSTA, 1997:283).

No entanto, refutando os argumentos de Costa (1997), pesquisas mais recentes apontam que apesar do comércio negreiro não ter sido extinto, algumas mudanças significativas aconteceram desde então (MAMIGONIAN \& GRINBERG, 2007; AZEVEDO, 2010). O fato de ter sido atribuído um caráter ilegal ${ }^{125}$ ao comércio negreiro, provocou algumas mudanças estratégicas e logísticas nas operações, acarretando modificações nas embarcações, alterações nos locais de embarque e desembarque dos africanos e envolvendo novos atores que atuavam tanto por mar quanto por terra (RODRIGUES, 2005). A demanda por mão-de-obra continuava de "vento em popa" a partir de 1831, principalmente para o trabalho nas lavouras de café que estavam em franca expansão no Sudeste brasileiro e foi responsável por absorver a grande maioria dos africanos que lá desembarcavam, mantendo um mercado vibrante em boa parte do século XIX.

Com anuência do Brasil, os navios ingleses passaram a interceptar as embarcações que faziam a rota África/Brasil visando à apreensão daquelas que transportassem africanos escravizados. Como se sabia que os traficantes a bordo das embarcações se livrariam da carga quando avistassem um navio inglês, as evidências de que essas embarcações estavam preparadas para o transporte de africanos já eram consideradas pretexto para sua apreensão.

Para Matos, as viagens transoceânicas continuaram acontecendo e, apesar dos desembarques não acontecerem mais nos portos tradicionais,

(...) há muitas notícias sobre desembarques ilegais de africanos ao longo da costa brasileira, nas décadas de 1830 e 1840, em regiões distantes dos centros urbanos e mais protegidas da observação pública. Mesmo após a lei de 1850, há registros do contrabando de africanos em diversos locais do litoral brasileiro. Os desembarques ilegais, em geral em praias pouco frequentadas, contavam com apoio dos fazendeiros de áreas próximas ao litoral e da população local, além da tolerância das autoridades (MATTOS et al, 2014:19).

\footnotetext{
125 Nesse trabalho, até a promulgação da Lei Feijó em 1831 será considerado o transporte de africanos para o Brasil como comércio negreiro e após esse período, visto seu caráter ilegal, vou considerar tráfico negreiro/ tráfico de africanos escravizados.
} 
De acordo com Rodrigues, por causa da fiscalização inglesa, muitos artifícios foram usados pelos envolvidos no tráfico negreiro, sejam

(...) quando desviavam suas rotas marítimas, substituíam os portos mais tradicionais, como Uidá por Ajudá, por exemplo, por embarcadouros recémformados e muito menos conhecidos, por praias e enseadas ermas, e ainda quando definiam preferências por tipos mais leves de embarcações (RODRIGUES, 2005).

As modificações geradas nos mecanismos do tráfico que sucederam a Lei de 1831 podem ter levado a um aumento no número de morte dos cativos, visto que, em muitos casos, as embarcações vinham superlotadas, já que não existia uma legislação normativa e nenhum tipo de fiscalização, fazendo com que os índices de mortalidade chegassem aos impressionantes 35\% (RODRIGUES, 2000). Por causa da insegurança instaurada, os lucros precisavam ser garantidos e aumentar o número de africanos embarcados foi um dos caminhos encontrados pelos traficantes. A busca por outros locais de desembarque ao longo da costa brasileira - essa com bordas continentais sinuosas, portos naturais e enseadas ermas - foi amplamente explorada, e tal fato instaurou uma nova rede nesse imbricado comércio, que até então não havia sido empreendida. Nesse sentido, Carvalho (2012) enfatiza que

(...) depois de 1831, o tráfico mudou-se para os portos naturais do litoral, passando a empregar muita gente em diversas atividades. Barcos menores apoiavam os navios negreiros a alcançar à costa. A população local passou a ter novas oportunidades de emprego e negócios. Os traficantes tiveram que comprar ou arrendar os portos naturais ou se associarem a seus proprietários. O tráfico mudaria a economia e a política local (CARVALHO, 2012:223)

$E$, assim, o tráfico negreiro foi se adaptando às primeiras proibições e os mercados continuaram a ser abastecidos com a mão-de-obra africana. No entanto, em agosto de 1845, com a crescente tensão entre o Brasil e a Inglaterra, é assinado um ato parlamentar que ficou conhecido como "Lei Bill Aberdeen". Essa ação acabou pressionando mais ainda o Brasil para que abolisse o tráfico de escravos. A soberania brasileira em relação as embarcações negreiras, já apreendidas ou as que seriam, passou a ficar fragilizada. O Brasil acata tal ato e vira "espectador da marinha inglesa".

Anos mais tarde, foi promulgada a Lei nํ. 581, de 4 de setembro de 1850, conhecida como "Lei Eusébio de Queiróz", que veio ratificar a ilegalidade do comércio negreiro e forçou o governo a empregar esforços para que essa lei fosse cumprida. 
Apesar do lobby dos proprietários de africanos escravizados nas altas esferas políticas, buscas foram empreendidas tanto por terra quanto por mar visando à coibição ao tráfico. Segundo levantamento feito por Jaime Rodrigues (2005), as apreensões de embarcações negreiras registradas iniciam-se a partir de 1849 e, ao final de 1857, totalizam vinte e duas. Quanto a essa data, importante observar que a primeira apreensão só foi registrada em 1849, ou seja, 18 anos após a criação de Lei Feijó e bem próxima a promulgação da Lei Eusébio de Queiróz, que foi concebida num momento onde as tensões envolvidas entre o Império e os ingleses estavam ficando insustentáveis.

O fato é que o transporte de africanos escravizados, apesar de proibido legalmente em 1831, continuou a acontecer. Os motivos que impulsionaram tal atividade, agora considerada ilícita, estão relacionados às demandas econômicas que o Brasil tinha como, por exemplo, uma agricultura cafeeira em franca expansão no sudeste e completamente dependente da mão-de-obra escrava.

Além da demanda do mercado interno, os contornos sinuosos e as praias abrigadas que marcam porções da costa brasileira, são aqui entendidos como facilitadores desse tráfico, uma vez que possibilitam a aproximação discreta e segura de embarcações. Tais características eram determinantes para o estabelecimento do apoio logístico, e isso tinha influência direta no número de pessoas envolvidas e os gastos imputados. Nesse sentido, os

(...) traficantes que operavam nas costas brasileiras sentiam-se alarmados, e, ante a maior pressão inglesa, desenvolveram novas táticas para efetuar o contrabando, tanto em mar como em terra (entre elas, podemos apontar a crescente busca de portos mais isolados para o desembarque de negros) (BOCCIA e MALERBI, 1977:334).

Vários autores indicam locais onde provavelmente foram realizados os desembarques de africanos escravizados após a lei de 1831. No entanto, muitas vezes, os textos historiográficos indicam apenas os municípios onde esses desembarques teriam acontecido, não indicando os nomes das praias, por exemplo. Quando os nomes das praias são indicados, em alguns casos observados para o litoral norte paulista, uma determinada praia está associada a um município diferente do que atualmente se conhece. Quando isso aconteceu, fiz a opção de considerar as 
divisões municipais atuais. Na dúvida sobre a qual município pertencia a praia indicada, desconsiderei a praia.

Nesse sentido, Camilla Agostini (2011) assinala alguns pontos espalhados pelo litoral brasileiro como de grande importância para os desembarques clandestinos, em particular a Ilha de Marambaia, Itaguaí, Mangaratiba, Ilha Grande, Angra dos Reis e Paraty, no litoral Sul do Rio de Janeiro, e Ubatuba, Caraguatatuba, São Sebastião e Ilhabela, no litoral norte de São Paulo. Walter Luiz Pereira (2011) traz apontamentos sobre os desembarques clandestinos do litoral do Espírito Santo, principalmente na porção sul da antiga província. Hebe Mattos (et al 2014) traz à baila quinze locais que foram identificados como pontos de desembarque ilegal ao longo da costa do Brasil, abarcando municípios do estado de Pernambuco (Goiana, Itamaracá, Ipojuca), Bahia (Camamu, Pontinha/Vera Cruz), Rio de Janeiro (São Francisco de Itabapoana, Búzios, Campos dos Goytacazes, Mangaratiba, Angra dos Reis), São Paulo (São Sebastião e Cananéia), Paraná (Paranaguá), Santa Catarina (Florianópolis) e Rio Grande do Sul (Capão da Canoa). Ronaldo Lima da Cruz (2010) indica que aconteceram desembarques no litoral da Bahia, principalmente aqueles realizados em Ilhéus, e apresenta mais detalhadamente um desembarque acontecido em 1851. Pierre Verger expõe um desembarque acontecido na llha de Itaparica (Bahia), em 1851, sendo que esse caso ficou conhecido como o "desembarque da Pontinha" (VERGER, 1987). Priscila Alonso (2006) aponta alguns municípios do estado do Rio de Janeiro (Paraty, Angra dos Reis, Macaé, Maricá) e de São Paulo (Caraguatatuba, São Sebastião, Itanhaém, Peruíbe, Ubatuba, Iguape, Cananéia e Santos) como prováveis locais de desembarque ilegal, além do município de Paranaguá no estado do Paraná. Para Rodrigues (2005:147) os desembarques aconteciam em municípios do estado de São Paulo como Caraguatatuba, Ubatuba, São Sebastião, Ilhabela, Bertioga (praia de Boracéia e Guaratuba), Santos, Itanhaém, Peruíbe, Iguape e Cananéia. O autor ainda acena para municípios na Bahia, Espírito Santo, Rio Grande do Norte e Paraná. Amaral (2007) aponta para desembarques em Sergipe; Bezerra (2013:5-10) indica desembarques ilegais na costa do Rio de Janeiro, principalmente em Angra dos Reis, Mangaratiba, Cabo Frio, Niterói e Barra de São João. França (1954:101) indica dois pontos no município de Ilhabela, especificamente na baía de Castelhanos usados para desembarques clandestinos: o Saco do Sombrio e a Praia da Figueira. 
No estado de Pernambuco, de acordo com Carvalho (2012), as praias de Itamaracá, Cabo de Santo Agostinho, Porto de Galinhas, Rio Formoso e Tamandaré permitiam a entrada de embarcações de até cem toneladas. Apesar de não possuir uma faixa litorânea tão extensa, o litoral pernambucano foi palco de inúmeros desembarques ilegais de africanos e, segundo Costa,

(...) a geografia da província, com sua infinita linha de arrecifes, transformava cada corte em um porto natural, facilitando a clandestinidade. Seguindo pela costa do norte ao sul, as praias de Barra de Catuama, Itamaracá, Pau Amarelo, Cabo de Santo Agostinho, Porto de Galinhas, Barra de Sirinhaém, a foz do Rio Formoso, Tamandaré e Una serviram de ancoradouro para navios de pequeno e médio porte descarregarem seus contrabandos, seja de pessoas ou mercadorias. Além disso, os africanos traficados podiam fugir e se embrenhar nas matas dos engenhos mais próximos sem que as autoridades provinciais tomassem conhecimento (COSTA, 2013:192-193).

De acordo com Leandro (2003), outros autores ${ }^{126}$ já apontaram a baía de Paranaguá (estado do Paraná) como porta de entrada de africanos ilegalmente traficados, já Nilma Teixeira Accioli (2010) assinala que o município de Cabo Frio também foi alvo de desembarques de africanos no período de ilegalidade, inclusive apontando uma área de mais de 50 quilômetros (entre Peró - Cabo Frio - e, Rio das Ostras), de costa sendo usada para os desembarques clandestinos, "com vários traficantes (...) atuando nas diferentes praias, aproveitando as características da região, fossem as naturais, com praias isoladas e propícias aos desembarques, e pela presença de fazendas com cultivo de produtos tropicais" (ACIOLLI, 2010:9).

Em levantamento realizado por Leslie Bethell, o autor indica que

(...) desembarques ilegais eram também feitos regularmente na Bahia ou vizinhança (em Itaparica, ilha dos Frades, Santo Amaro do Ipitanga e na bela praia de Itapuã), em Pernambuco e, menos frequentemente, em Paranaguá (200 milhas ao sul de Santos) e nas províncias de Santa Catarina e Rio Grande do Sul. Mesmo o comércio baiano, entretanto, constituía agora apenas um pequeno ramo do crescente comércio metropolitano que servia as plantações de açúcar do Rio e de São Paulo e, mais importante, as áreas de café em desenvolvimento no vale do Paraíba (BETHELL, 2002:100).

126 Calógeras, Martins, Carneiro, Westphalen, Ferrarini, Bethel e Rodrigues apud, José Augusto Leandro. Em águas turvas: navios negreiros na baía de Paranaguá. Esboços (UFSC), Chapecó, v. 10, pp. 99-117, 2003. 
Segundo Leite (1998), em 11 de outubro de 1855 foi realizado por um palhobote ${ }^{127}$ português o desembarque de africanos na ilha de Santo Aleixo, nos mares de Serinhaém, no estado de Pernambuco. Esse caso teve bastante notoriedade a época porque o desembarque foi realizado em um local diferente do combinado, o que acabou acarretando grandes prejuízos ao comandante da embarcação, devido ao "ágio" que foi obrigado a pagar pelo erro cometido. Esse episódio ficou conhecido como o "desembarque de Serinhaém” (DRUMMOND, 1856; TRECCANI, 2006:79; LEITE, 1988).

Nos anos de 1855 e 1856, a "boataria a respeito de possíveis desembarques nas costas brasileiras corria à solta", ou seja, cinco a seis anos após a Lei Eusébio de Queiróz possíveis desembarques ainda estavam acontecendo (LEITE, 1988:351). Boccia e Malerbi (1977) realizaram um estudo sobre o contrabando de africanos escravizados para São Paulo e identificaram rastros do tráfico entre 1852 e 1856 e, após intervalo considerável, voltando a uma breve ocorrência entre 1869 e 1870. Além disso, apontam desembarques provavelmente realizados em Ubatuba, Caraguatatuba e São Sebastião, além de várias ilhas

(...) que acompanham o litoral paulista: Queimada, Guaraú, Tamanduá, Vitória, São Sebastião, e outras. Dada a natureza dessa costa, bastante recortada e, portanto, formada de numerosas baías e ensedas, abrigadas, ao norte da Província, pelas encostas da Serra do Mar; e dada a sua grande extensão, o que também dificultava uma vigilância contínua por parte das autoridades, a ação dos contrabandistas era largamente facilitada (BOCCIA e MALERBI, 1977: 348).

Rodrigues (2005) aponta que se já não bastassem as articulações e especulações envolvendo corruptores e corruptíveis nesse período do tráfico, uma alternativa utilizada pelos traficantes para fugir do risco de ser apreendido pelas embarcações inglesas e/ou brasileiras era se desfazer das embarcações - que significavam provas cabais - encalhando-as ou incendiando-as após descarregarem suas cargas. Uma faceta do caso do brigue Camargo, por exemplo, que foi incendiado pela sua tripulação que depois tentou fugir do país pelo porto de Santos (ou de Paranaguá) (ABREU, 1995).

\footnotetext{
127 Veleiro de dois mastros, usando em ambos, velas latinas quadrangulares. Possui uma grande área de velame, o que the permite alcançar grande velocidade e uma boa manobrabilidade. Informação extraída do Dicionário informal, disponível em http://www.dicionarioinformal.com.br/palhabote/.
} 
Como observado nos parágrafos anteriores, em muitos casos, os municípios do litoral norte paulista são citados com tendo sido utilizados para o desembarque de africanos. No entanto, em alguns casos é possível obter a informação sobre a praia onde o desembarque aconteceu, como se observa, por exemplo, na citação anterior, onde Boccia e Malerbi (1977) indicam as ilhas do Tamanduá (Caraguatatuba) e ilha de São Sebastião (Ilhabela) ${ }^{128}$.

No entanto, para as autoras, havia

(...) a grosso modo, duas zonas especialmente visadas para desembarques clandestinos, pelos contrabandistas: uma entre lguape e Santos, principalmente Iguape, Itanhaém e Bertioga; e outra entre Santos e Angra dos Reis, destacadamente as praias situadas nas proximidades do Rio Una até São Sebastião e Bracuí. Essas regiões litorâneas eram as preferidas pelos contrabandistas por serem, além de isoladas, pontos de onde era fácil o acesso aos mercados consumidores (BOCCIA e MALERBI, 1977:348, grifo meu).

O espaço compreendido entre o rio Una até o centro de São Sebastião, considerando apenas sua linha de costa, abrange uma extensão de mais de 50 quilômetros e abarca várias praias, além da própria praia da Barra do Una (ALONSO, 2006: 99, 102). A partir dela, no sentido leste estão outras duas praias que são citadas nos textos historiográficos como pontos de desembarque: a Praia da Barra do Sahy (ALONSO, 2006: 85, 101; RODRIGUES, 2000:147) e Praia de Toque-Toque Grande (ALONSO, 2006: 85, 101; BOCCIA e MALERBI, 1977:351).

De acordo com Marcílio (2006), na calada da noite de 4 de dezembro de 1840, por exemplo, foram registrados desembarques clandestinos de dois navios na praia do Bonete, em Ubatuba. Acredita-se que aproximadamente 700 africanos escravizados tenham sido desembarcados e depois levados até a fazenda de Francisco Xavier Duarte da Veiga, da Praia de Tabatinga ${ }^{129}$, segundo denúncia feita pelo juiz de paz (Ubatuba, carta de 05/12/1840, in APESP, caixa 530, apud MARCÍLIO, 2006:124). A praia de Tabatinga também é citada por Alonso (2006) como ponto de desembarque e, a ilha do Tamanduá, que está localizada a frente a essa

\footnotetext{
${ }^{128}$ As autoras também indicam a llha Vitória. No entanto, no litoral norte existe a llha da Vitória que compõe o arquipélago de llhabela e a llha Vitória que faz parte do município de Ubatuba. Como as autoras ao longo do texto não deixam claro a qual ilhas se referem, fiz a opção por não detalhar essa informação.

${ }^{129}$ A praia de Tabatinga atualmente está alocada no município de Caraguatatuba, mas como fica no limite com Ubatuba, muitas vezes a documentação atribui sua localização a Ubatuba. Como no caso desse desembarque, a praia do Bonete é Ubatuba e a de Tabatinga, Caraguatatuba. Para esse trabalho a Praia de Tabatinga será considerada como pertencente ao município de Caraguatatuba.
} 
praia, também aparece no levantamento realizado por Boccia e Malerbi (1977) como tendo sido utilizada para o desembarque de africanos durante o período de ilegalidade.

O município de Ubatuba, dentre os quatro municípios do litoral Norte, é o que apresenta as bordas continentais mais recortadas, conforme visto anteriormente e, por isso, a referência as praias utilizadas como pontos de desembarques clandestinos são mais numerosas. Dessa feita, na "costa Norte", são citadas as praias de Ubatumirim (OLIVEIRA, 1977:89) e praia Barra Seca (RODRIGUES, 2000:147) e, para a "costa Sul", tem-se a praia da Fortaleza (OLIVEIRA, 1977:89), praia da Lagoinha (BOCCIA e MALERBI, 1977: 361; ALONSO, 2006:85) praia da Maranduba (ALONSO, 2006), praia da Caçandoca (OLIVEIRA, 1977:89) e praia do Bonete (MARCÍLIO, 2006:124).

É na baía de Castelhanos, localizada na face leste da llha de São Sebastião, principal ilha do município de Ilhabela, que estão os locais indicados como pontos de desembarques clandestinos, conforme os textos consultados para esse trabalho. A praia dos Castelhanos, a maior da baía é indicada por Noffs (2207:15), além da praia da Figueira e do Saco do Sombrio (FRANÇA, 1964:101; RODRIGUES, 1995:146147), conforme podemos verificar nas palavras de França,

(...) pode-se verificar como era fácil, em face da existência de portos negreiros, como os da Baía dos Castelhanos, adquirir mão-de-obra africana. Por preços insignificantes compravam-se negros doentes, julgados incapazes de vencer a subida da serra, pelas precárias condições em que chegavam ao porto de desembarque, depois de penosa viagem oceânica" (FRANÇA, 1954:143).

Apesar das referências aos desembarques nas praias, Carvalho adverte que pouco ou quase nada se sabe sobre como o tráfico era "efetivamente operacionalizado nas praias brasileiras, como era a chegada de um navio negreiro fora dos portos das capitais, como se davam os desembarques" (CARVALHO, 2012; 225). Acredita-se que muitas pessoas estavam envolvidas, mas pouco se sabe quem trabalhava nisso, o que de fato era preciso para a recepção dos africanos para que se procedesse a recuperação física - tão prejudicada pelas longas viagens - e como era feita a vigilância e tratamento dos africanos recém desembarcados. O fato é que o tráfico negreiro mudou significativamente a vida do litoral brasileiro a partir de 1831 . 
Alguns dos locais citados acima e indicados nos textos historiográficos como pontos de desembarques ilegais, juntamente com as informações orais obtidas com moradores locais, foram alvo de prospecções superfície e os resultados dessa ação serão retomados ao final deste capítulo.

\subsection{Olhar a partir da Oceanografia}

A Oceanografia possibilita o estudo de diversos compartimentos relacionados ao ambiente aquático, não só marítimo, mas também em corpos de água doce. Abarcando disciplinas associadas às áreas física, química, biológica e geológica, a Oceanografia pode fornecer ferramentas importantes, entre outros aspectos, para o entendimento, por exemplo, dos processos pós-deposicionais de um sítio arqueológico que se encontra total ou parcialmente submerso.

Nesse sentido, são inúmeras as possibilidades de pesquisas arqueológicas utilizando aspectos abordados pela Oceanografia. No entanto, o presente estudo apresentará algumas possibilidades por meio de dois vieses, a saber: as correntes marinhas ${ }^{130}$ e a dinâmica costeira, notadamente aquela relacionada aos fenômenos de progradação ${ }^{131}$. A escolha desses vieses se dá no sentido de que o conhecimento de aspectos relacionados às correntes marinhas pode colaborar no entendimento da escolha dos locais de desembarque. Já o conhecimento das dinâmicas de progradação podem possibilitar o entendimento de locais com potencial para a identificação de evidências enterradas que tenham sido deixadas ou transportadas para a praia ou para a zona entremarés.

No Brasil, a zona costeira está inserida no capítulo VI, artigo 255, da Constituição Federal, como um patrimônio natural. E pode ser definida, em linhas gerais, como a "região onde o continente encontra o mar, constitui uma zona de fronteira sujeita a contínuas alterações morfodinâmicas, modeladas por processo de origem continental ou marinha" (SILVA et al, 2004:175). O país possui 7.367 quilômetros de linha de costa, sem levar em conta os recortes como as baías, enseadas e reentrâncias, que

\footnotetext{
130 De maneira geral, pode-se definir as correntes marinhas como os movimentos de translação, permanente e continuado de uma massa de água dos oceanos.

${ }^{131}$ Mecanismo de avanço da linha costeira (coastline), mar adentro, normalmente relacionado a sedimentação por processos marinhos litorâneos ou fluviais (SUGUIO, 1992:101).
} 
ampliariam significativamente essa extensão, elevando-a para mais de 8,5 mil quilômetros. Em sua maior porção, o litoral brasileiro está situado no Atlântico Sul, com pequena parcela (extremo norte do país) situado no mar do Caribe (IBGE,1991). Diante disso, é importante observar que extensos trechos do litoral brasileiro

(...) são caracterizados por grandes depósitos de areias marinhas, na forma de cordões litorâneos, pontais e planícies de cristas de praia. Também ocorrem segmentos representados por terraços lamosos ocupados por manguezais e falésias em sedimentos consolidados, precedidas por praias muito estreitas ou muitas vezes ausentes (MUEHE, 2006:5).

Com um litoral tão extenso, o que não faltava eram opções para o desembarque dos africanos, pois os locais passíveis de aproximação de embarcações eram inúmeros. Nesse sentido, é preciso buscar entender quais as variáveis que eram levadas em conta para a escolha desses pontos. Como visto anteriormente, pouco se sabe sobre os desembarques realizados fora dos portos tradicionais e, por isso, a busca por possibilidades que ajudem nesse entendimento, aqui apontadas pelo viés das correntes marinhas que orientavam a navegação, podem contribuir positivamente para o entendimento dessa complexa rede.

\subsubsection{Correntes marinhas}

As correntes marítimas são consideradas como "verdadeiros rios de água salgada" e junto com as ondas ${ }^{132}$ e marés ${ }^{133}$, constituem os três principais movimentos oceânicos. Conhecer a direção e intensidade das correntes poderia, a grosso modo, fazer a grande diferença entre a chegada ou não das embarcações na data estipulada a um determinado local. Sem dúvida a experiência e a perspicácia dos capitães das embarcações negreiras foi crucial para o sucesso das viagens e posterior desembarque dos africanos. De acordo com Alencastro (2000:57), o "oceano está

\footnotetext{
132 As ondas observadas nos oceanos são ondas mecânicas produzidas pela força motriz dos ventos, movimentos da crosta terrestre (terremotos e maremotos) e forças astronômicas. A criação dessas ondas tem a participação da gravidade e da capilaridade que atuam como forças restauradoras do nível do mar. Sem a ação das forças restauradoras uma dada porção do mar que se elevasse pela ação das forças motrizes permaneceria elevada indefinidamente (GOMES, 2003:2).

133 De maneira geral, pode-se considerar que as marés são variações verticais periódicas do nível do mar, resultantes da atração gravitacional exercida pela Lua sobre a Terra e, em menor escala, da atração gravitacional exercida pelo Sol sobre a Terra.
} 
cortado por vias balizadas pelos ventos, canalizadas pelas correntes e pautadas nas estações".

Para Carvalho (2012), com os desembarques acontecendo fora dos portos tradicionais, a própria chegada ao ponto exato de desembarque por si só já era uma atividade extremamente complexa, pois

(...) os traficantes não podiam mais se guiar por faróis permanentes encimados nas encostas contíguas às grandes cidades, evitando mais facilmente os arrecifes, os bancos de areia, sendo informados das correntes mais fortes e da direção a ser tomada para entrar na barra (CARVALHO, 2012:228)

Como se observa nas palavras de Carvalho (2012), com os desembarques sendo realizados fora dos portos convencionais, as aproximações das embarcações nos pontos determinados estavam entregues à própria sorte. Sendo que as variáveis oceanográficas, além das meteorológicas, acabavam assumindo um caráter decisivo para o sucesso ou fracasso da travessia.

É importante destacar que existiam diferenças significativas entre o embarque e o desembarque de africanos realizados nas praias. No embarque, por mais que o temor de apreensão existisse, os africanos, na maioria das vezes, ainda estavam em condições físicas estáveis. Nesse sentido, o transporte em pequenas embarcações que faziam o translado até os negreiros, por mais que enfrentassem ondas altas e distâncias superiores a 150 metros, não encontrava mais dificuldades dos que as esperadas, visto que os cativos podiam sustentar seus corpos e com isso colaborar no equilíbrio da embarcação. Nos desembarques, os africanos estavam absolutamente debilitados, devido à má alimentação, a escassa ingestão de água e, em muitos casos, ainda estavam doentes e cegos (muitas vezes, a falta de higiene no manuseio dos alimentos e no próprio local onde os cativos permaneciam durante praticamente todo o trajeto provocavam infecções que resultavam em cegueira). Além, é claro, do escorbuto ${ }^{134}$, que acometia não só os africanos como também a tripulação, principalmente pela falta de ingestão de vitamina $\mathrm{C}$ e alimentos frescos. Em viagens que podiam durar até dois meses, ingerindo em média meio litro de água por dia, em

134 De uma maneira geral, o escorbuto é uma doença carencial (falta de nutriente essencial), devido à ausência de vitamina C (ou ácido ascórbico). Os principais sintomas são Hemorragias gengivais, inchaço com pus na língua ou nas gengivas, dores nas articulações, dificuldades de cicatrização das feridas e dentes soltos. Disponível em http://www.abc.med.br/ acessado em 12 de novembro de 2016). Antigamente era uma doença bastante comum naqueles que passavam longos períodos em alto mar. 
interiores de embarcações cujas temperaturas ultrapassavam os 40 graus célsius, os cativos que conseguiam resistir à travessia chegavam em condições severas de debilidade física (RODRIGUES, 2005). Nesse sentido, não era uma ação fácil promover o desembarque dos cativos para as pequenas embarcações de apoio que os levariam até as praias. A fragilidade dos africanos poderia provocar instabilidades nas embarcações, ou mesmo quedas no mar. Segundo Carvalho (2012:233) "os cativos chegavam estropiados, desidratados, esfomeados, muitos certamente incapazes de se segurarem com firmeza". Por isso, quanto mais calmo estivesse o mar nos pontos de desembarque, mais protegido visualmente dos portos principais ou dos núcleos urbanos, mais fácil fosse o acesso a fontes de água doce e mais próximo do destino, maior a probabilidade de sucesso.

As embarcações que saiam dos portos localizados na costa africana subsaariana $^{135}$, provavelmente navegavam sentido norte pela Corrente de Benguela até a altura da Linha do Equador, quando aproveitavam a Corrente sul equatorial até chegarem próximos ao continente sul americano, onde já era possível seguir pela corrente do Brasil ${ }^{136}$ para alcançar os pontos localizados no nordeste, sudeste e sul do país. Para acessar os portos da região Norte, mantinha-se a corrente norte equatorial (MACHADO et al, 2011). As direções, assim como a intensidade das correntes, até hoje são fundamentais na hora de efetuar os cálculos de navegação, mesmo com embarcações a propulsão. A figura abaixo (figura 7) exibe a direção e temperatura das correntes que ligam o continente sul-americano ao continente africano.

\footnotetext{
135 Também chamada África negra, corresponde à parte do continente africano situada ao sul do Deserto do Saara. Não é uma divisão política, mas apenas um termo usado como referência aos países que possuem maior parte da população negra neste continente.

136 "A Corrente do Brasil (CB) é a corrente de contorno oeste associada ao Giro Subtropical do Atlântico Sul. Origina-se a sul de $10^{\circ} S$, na região onde o ramo mais ao sul da Corrente Sul Equatorial (CSE) se bifurca formando também a Corrente do Norte do Brasil (CNB). A CB então flui para Sul, bordejando o continente sul-americano até a região da Convergência Subtropical (33-38S), onde conflui com a Corrente das Malvinas e se separa da costa" (SILVEIRA, et al, 2000: 171).
} 


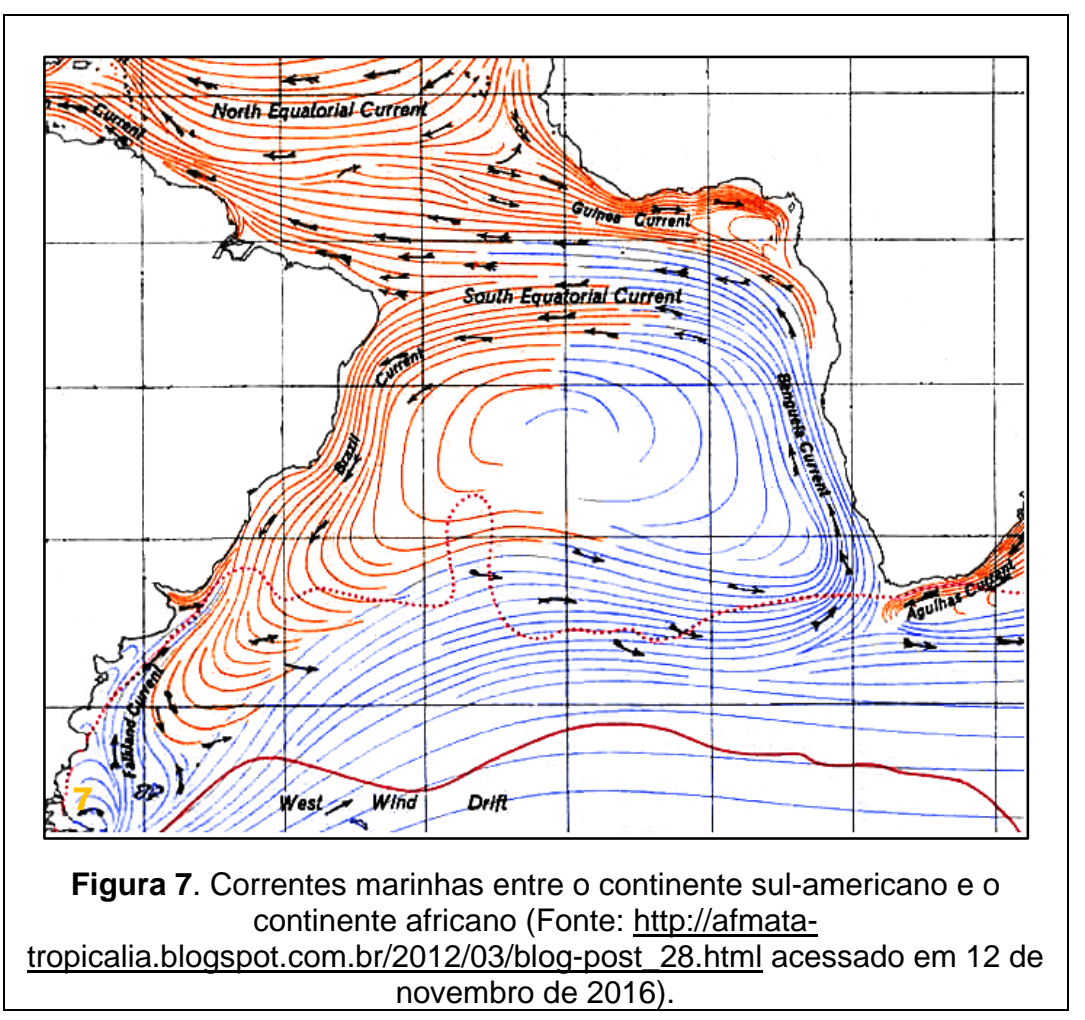

Nos séculos que antecederam as primeiras embarcações a vapor ${ }^{137}$, as dificuldades impostas pelas navegações oceânicas eram muitas. Os próprios fatores naturais, como tempestades e calmarias, além das limitações impostas pelos instrumentos de navegação utilizados na época ${ }^{138}$ - que, com exceção da bússola, se resumiam, majoritariamente, a instrumentos utilizados para a leitura das estrelas tornava ainda mais importante o conhecimento das variáveis oceânicas e podia ser determinante e influenciar de maneira significativa no desenvolvimento das viagens. Nesse sentido, algumas estratégias foram empreendidas a fim de programar as viagens e, de acordo com Tavares, a identificação de marcadores naturais podiam colaborar na orientação das embarcações, como é o caso por exemplo das

(...) Ilhas de São Tomé que estavam estrategicamente situadas nas proximidades das zonas marítimas de conversão formadas pela junção das correntes das Ilhas Canárias, de Benguela, do Brasil e das Guianas, o que facilitava a travessia do Atlântico tanto para as águas do norte em direção as colônias Inglesas, quanto para o sul em direção ao Brasil, tornando a viagem mais segura e rápida (TAVARES, 2012:44).

\footnotetext{
137 Nesse trabalho, a data considerada para início da utilização de embarcações a vapor será o final da primeira metade do século XIX. Lembrando que a utilização do vapor se iniciou por embarcações de menores tonelagens (SAMPAIO, 2006).

138 O astrolábio, o quadrante, a balhestilha, a bússola, a ampulheta, entre outros (PEREIRA, 2000).
} 
A partir do momento que uma embarcação alcançava a corrente do Brasil, podese considerar, a grosso modo, que apenas pequenas correções de curso eram necessárias até a chegada ao destino desejado. Caso se contasse com ventos constantes, principalmente os alísios ${ }^{139}$, e condições climáticas favoráveis, em tese, era apenas uma questão de tempo até a chegada próxima ao ponto marcado.

Para Carvalho,

(...) não era, portanto, qualquer ponto da costa que servia para desembarque de cativos. E mesmo nos locais adequados, não era a qualquer hora ou maré. O momento certo, de mar calmo, não podia ser desperdiçado. O local teria que ser exato, as circunstâncias também. O tráfico ilegal não era negócio para amadores (CARVALHO, 2012:230).

No entanto, apesar da gradual modificação dos tipos de embarcação utilizadas para transportar os africanos ter sofrido significativas alterações nos anos que sucederam lei de 1831, relacionadas principalmente ao tamanho, a fim de facilitar a entrada nos "portos naturais", tal fator não esgotava as dificuldades para o sucesso da operação. Mesmo após ter-se vencido a navegação atlântica, era preciso vencer a navegação costeira em si. Teoricamente, era possível construir na praia alguma estrutura alta para sinalização, ou, no mínimo, uma fogueira, mas isso não bastava para que a embarcação chegasse em segurança em um determinado ponto específico. De acordo com Carvalho (2012), o menor descuido e a embarcação poderia bater nos arrecifes ou encalhar nos bancos de areia nos deltas (principalmente aqueles dos rios maiores) e colocar tudo a perder. Era necessário atingir o ponto exato de entrada da barra, para que a aproximação fosse feita de maneira segura e sem atropelos. Para que as pessoas envolvidas na rede de apoio aos desembarques e na recepção dos africanos pudessem começar a agir. Mesmo com a embarcação ancorada, o risco de naufrágio não era o único problema a ser enfrentado por um negreiro que errasse a rota. Para Carvalho,

(...) nunca é pouco lembrar que o tráfico era um negócio ilegal, feito em freguesias onde as autoridades locais, regra geral, também eram proprietárias de terra e escravos. Assim, mesmo que fossem coniventes com o tráfico, não significava que iriam assistir seus vizinhos, muito menos concorrentes e adversários políticos, se beneficiarem sozinhos. Se um navio

139 Os ventos alísios são regulares e sopram constantemente em superfície, das regiões de altas pressões atmosféricas subtropicais, situadas em ambos os hemisférios nas latitudes de aproximadamente $30^{\circ}$, para as de baixas pressões próximas à linha do Equador. O encontro dos alísios dos dois hemisférios nas proximidades do Equador configura a Zona de Convergência Intertropical (ZCIT), caracterizada por calmarias ou ventos fracos em razão do contínuo movimento ascendente do ar e consequente acentuada instabilidade com precipitação abundante acompanhada de raios e trovões (MACHADO, 2011:7-8). 
negreiro fosse parar na praia errada, o potentado local que controlava o acesso a ela por terra poderia muito bem aproveitar a situação para se apropriar dos cativos desembarcados sem sua autorização (CARVALHO, 2012:241)

Com pouca margem para erros, os capitães das embarcações que traziam os africanos para o Brasil, e em especial para o litoral Norte paulista, precisavam ter muita técnica, astúcia e conhecimento dos recortes das bordas continentais para que pudessem fundear no lugar certo. O conhecimento do "ritmo" das correntes oceânicas e costeiras era fundamental, assim como as alterações que o oceano sofria por meio das mudanças climáticas relacionadas as estações do ano, eram fundamentais para minimizar os riscos a que tal atividade estava envolvida. Além disso, a ilha de São Sebastião é bastante conhecida por acidentes marítimos que resultaram no naufrágio de dezenas de embarcações dos mais variados portes. Esses acidentes muitas vezes estão associados a mudanças repentinas do clima e também a possível alteração mineralógica dos afloramentos rochosos que compõe o assoalho oceânico da llha de São Sebastião, principal ilha do município de Ilhabela (NAHAMY et al, 2011). Essa alteração, onde a quantidade de minerais de óxidos de ferro, notadamente a magnetita ${ }^{140}$, presente nas rochas e sedimentos estaria em maior concentração, poderia causar interferências nos instrumentos de navegação, sobretudo em embarcações mais antigas. O resultado das pesquisas feitas por Nahamy et al (2011:1) indicam a presença de magnetita em quantidades suficientes para provocar a alteração do "posicionamento das agulhas das bússolas" interferindo na orientação das embarcações. Esse fato, de acordo com a autora, pode sim ter provocado desorientações suficientemente significativas, que, associadas a variações meteorológicas, por exemplo, tenham resultado na ocorrência de naufrágios na região (NAHAMY et al, 2011; MORENO e PIRES, 2010).

\footnotetext{
${ }^{140}$ Fórmula Química - Fe3O4 - Composição - Óxido de Ferro. 31,0\% de FeO, 69,0\% de Fe2O3.
} 


\subsection{2. $\underline{\text { A Progradação }}$}

De acordo com Rocha (2011:57), "os agentes erosivos marinhos (maré, onda, corrente, variação do nível do mar), associados aos fluviais e eólicos, são os responsáveis pela fisionomia da zona costeira".

Para Tessler et al, o litoral do estado de São Paulo possui perto 400 quilômetros de extensão,

(...) sendo em grande parte constituído por praias arenosas. Neste trecho costeiro, ao contrário de muitos estados brasileiros, não são observados segmentos contínuos submetidos a processos generalizados de erosão ou progradação. O que existe são segmentos restritos de linha de costa, submetidos a processos erosivos ou acrescionais, sendo estes, em geral relacionados com a existência de obstáculos naturais ou construídos, que alteram a dinâmica sedimentar original. Tanto os obstáculos naturais como os construídos modificam a interação da posição geográfica da linha de costa com o trem de ondas (2006:298).

A progradação pode ser positiva ou negativa. Considera-se progradação positiva quando ocorre o acréscimo de sedimento na zona praial e negativa quando acontece a retirada de sedimento. Deve-se atentar ao fato de que esse movimento é influenciado por vários fatores, tanto naturais quanto antrópicos. No entanto, apesar da progradação negativa provocar uma retirada de sedimento da zona praial, nada tem a ver com os processos erosivos ${ }^{141}$ a que esses ambientes estão expostos, uns em maiores e outros em menores proporções. Pois os processos erosivos vão retirar o sedimento de um determinado local e a remobilização não voltará a acontecer na mesma intensidade que foi retirada.

As praias são áreas intensamente dinâmicas e, de acordo, com a declividade da plataforma continental ${ }^{142}$, a retirada e deposição de sedimentos ocasionada pelos constantes processos de transporte sedimentar podem variar bastante (SOUZA, 2009). Da mesma forma, são vários os tipos de ondas que chegam às praias (Figura 8) e cada tipo provoca uma interação diferente com o sedimento praial.

\footnotetext{
141 A erosão costeira ocorre em $70 \%$ das praias arenosas de todo o planeta, o que torna esse processo uma preocupação global. A variação de sedimentos numa praia (ganho e perda) é chamado de balanço sedimentar. A erosão ocorre quando o balanço sedimentar de uma praia é negativo, ou seja, quando a praia perde mais sedimentos do que recebe. O recuo da linha de costa é uma consequência deste processo (SOUSA, S/D).

142 A plataforma continental tem profundidade média de 200 metros e largura média de 90 quilômetros.
} 


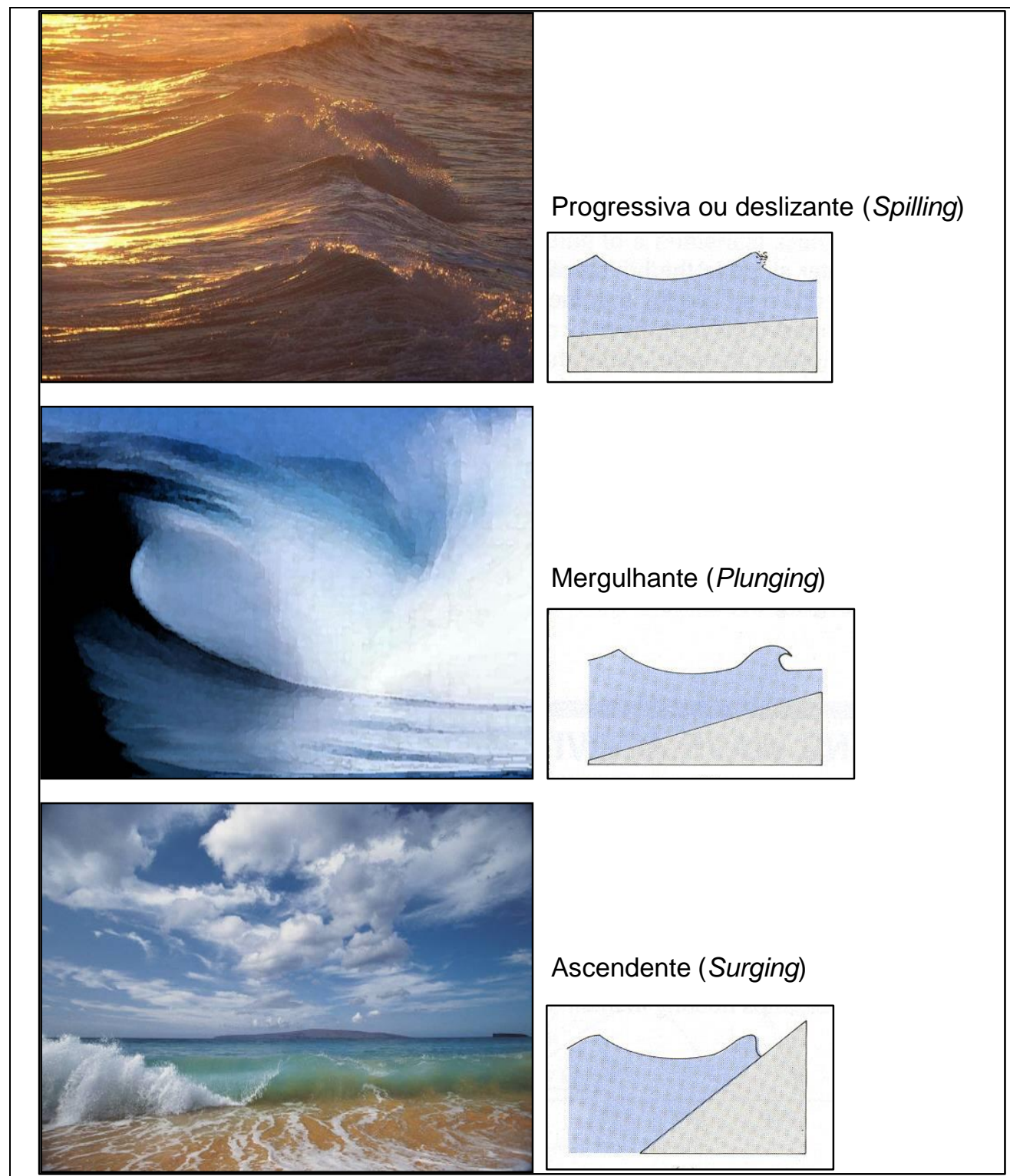

Figura 8. Tipos de ondas mais comuns (Adaptado de GOMES, 2003:11).

O conhecimento da tipologia das praias do litoral Norte permite um melhor entendimento sobre os diversos componentes dinâmicos, que, segundo Fairbridge (1968), seriam as alterações diárias produzidas pela maré; alterações quinzenais, relacionadas a marés de sizígia; alterações anuais, dadas por variações sazonais do nível médio do mar e alterações de longo prazo do nível médio do mar.

Ainda de acordo com Fairbridge (apud TESSLER et al, 2006)

A estes componentes devem-se acrescentar as tendências de erosão ou acúmulo sedimentar, relacionadas com 0 transporte desses sedimentos provocado pela ação das ondas e correntes de deriva litorânea. A ação antropogênica também deve ser considerada. 
Conforme apontado anteriormente, apesar das praias localizadas na área de estudo não apresentarem segmentos contínuos afetadas por dinâmicas relacionadas a erosão e a progradação, o litoral Norte paulista, exibe praias de pequenas extensões, excetuando a da enseada de Caraguatatuba, que é o maior segmento contínuo da região, as demais praias em apreço constituem segmentos restritos (TESSLER et al, 2006).

O conhecimento dos mecanismos de progradação de uma determinada praia, associado a outras variáveis, como a taxa de sedimentação por exemplo, podem apontá-la ou não como área potencial para a possível identificação de evidências arqueológicas que estejam enterradas na zona entremarés. Recentemente, a passagem do furacão Matthew, na Carolina do Sul, provocou grandes prejuízos e os ventos provocaram grandes tempestades no mar. A violência das ondas provocou uma ampla remobilização sedimentar e uma progradação negativa com a retirada de grande quantidade de areia da praia, sendo que essa situação acabou por revelar antigas bolas de canhão, provavelmente da época da Guerra Civil estadunidense. As imagens abaixo (Imagem 28 e 29) mostram as bolas de canhão bastante oxidadas e que estavam enterradas na zona entremarés. Foi necessário um evento meteorológico de grande magnitude para que peças pudessem ficar expostas.

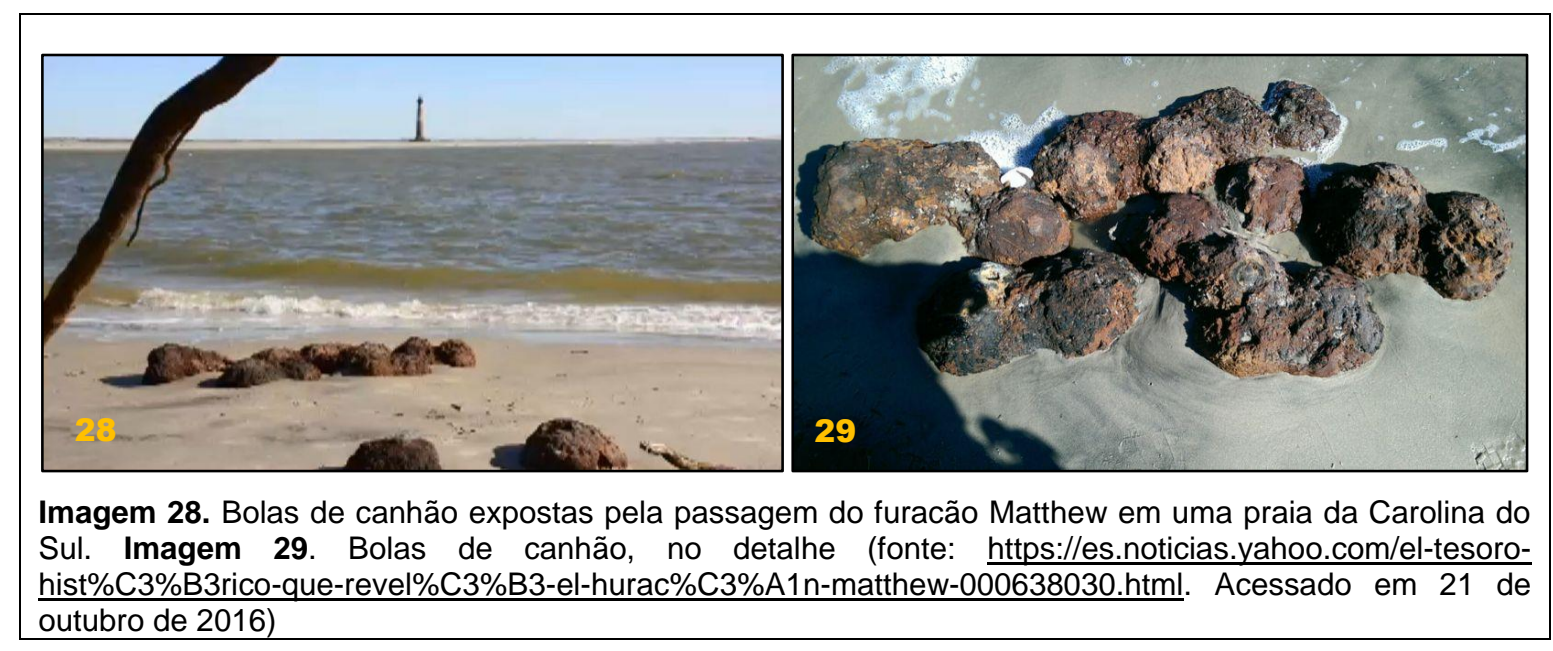

Da mesma forma que as areias de uma praia da Carolina do Sul continham evidências enterradas, um caso similar aconteceu na praia de Castelhanos, em Ilhabela, e ajuda a ratificar o potencial da zona entremarés e a importância das dinâmicas de progradação e erosão. Após um período de fortes chuvas que assolou 
a região, o volume hídrico de um pequeno riacho que desemboca no canto sul da praia dos Castelhanos, local esse conhecido como canto da Lagoa, revelou sob suas areias a presença de uma embarcação de madeira que há muito tempo estava enterrada. Segundo a arqueóloga Cintia Bendazzoli143, responsável pelo cadastro da embarcação, acredita-se que seja oriunda do Norte da Europa e o resultado da datação por $\mathrm{C}^{14}$ apontou que a embarcação é do século XIX, e remete a $1840( \pm 30$ A.P). A imagens abaixo mostra os destroços da embarcação que foram expostos após as intensas chuvas que caíram na região (Imagem 30). A Imagem 31 foi obtida em setembro de 2016 e mostra a área onde os destroços haviam sido identificados, tento sido totalmente enterrados pela própria dinâmica sedimentar, sendo que hoje apenas uma placa marca o local dos destroços.

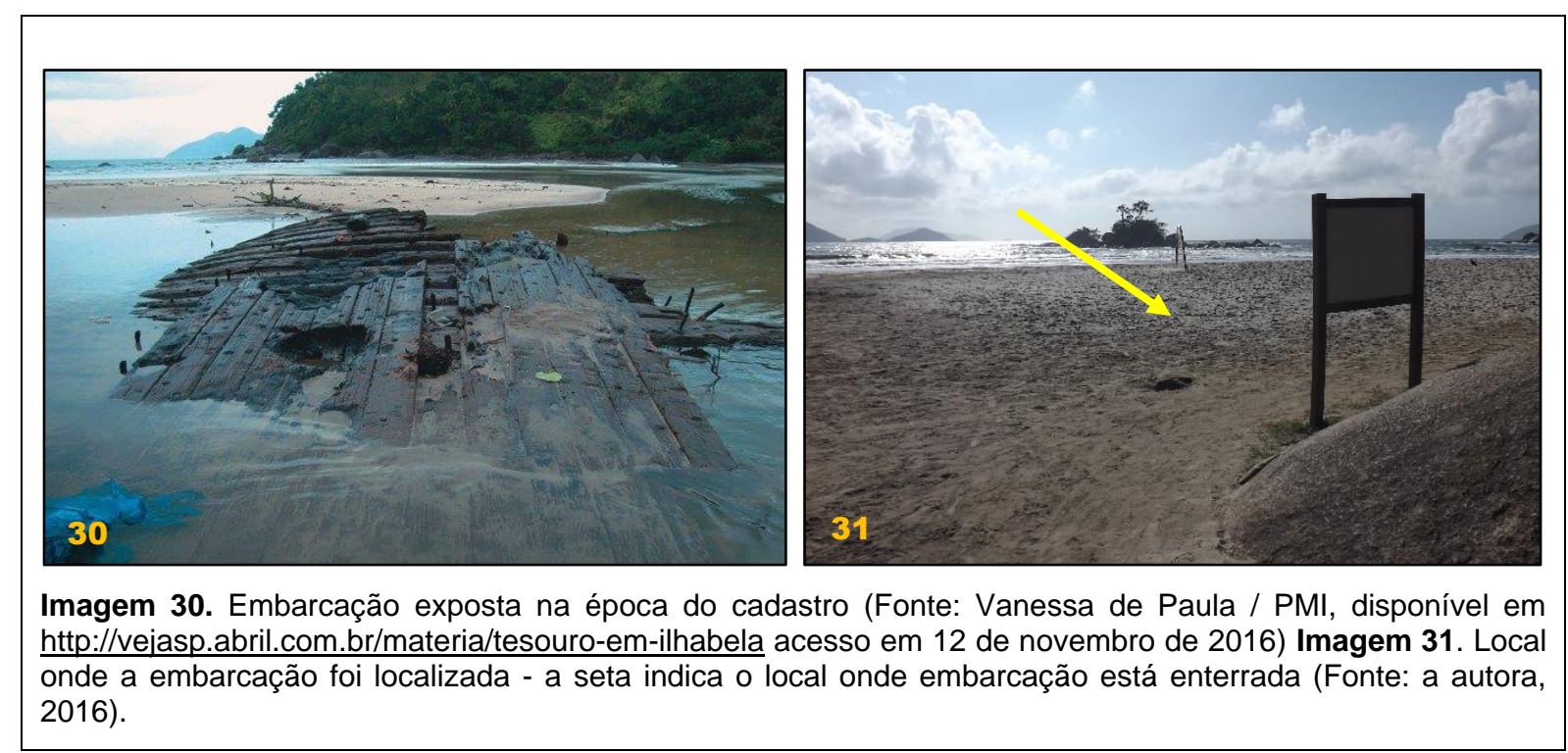

Importante ressaltar que a intensa ocupação do litoral Norte paulista a partir da década de 1950 acarretou distintas interferências sobre o compartimento costeiro. Essas intervenções são caracterizadas, principalmente, pela construção de aterros em manguezais, retificações dos leitos dos rios, rebaixamento do lençol freático e extração das areias das praias, que acarretaram diversas e significativas alterações no balanço sedimentar da costa, que é composta, sobretudo, por praias arenosas (TESSLER et al, 2006). Nesse sentido, a Oceanografia com sua abrangência

143 O cadastro foi realizado no âmbito do Projeto de Gestão e Diagnóstico Arqueológico de Ilhabela, por meio do Instituto Histórico Geográfico e Arqueológico de Ilhabela (IHGAI). 
multidisciplinar pode colaborar no entendimento das dinâmicas envolvidas na escolha dos locais utilizados para os desembarques clandestinos dos africanos, assim como proporcionar novos olhares para a zona entremarés que colaborem na identificação de locais com potencial para a localização de evidências arqueológicas.

Obviamente, a dinâmica oceanográfica não age isoladamente nos casos de alteração da linha de costa, atua conjuntamente com a dinâmica geomorfológica, climática e geológica, além da ação antrópica, que, conectadas, podem gerar alterações significativas na dinâmica continente-oceanos e provocar sensíveis alterações físicas.

\subsection{Olhar a partir da Arqueologia: algumas possibilidades}

Os métodos utilizados para obtenção de informações da área em tela tiveram uma abordagem multidisciplinar, pois contaram, primeiramente, com prospecção de superfície em alguns dos pontos que são indicados como locais de desembarques de africanos e que foram previamente selecionados. No geral, muitos dos textos consultados apresentavam os municípios de maneira vaga, não pormenorizando ou detalhando os pontos onde esses desembarques teriam acontecido. Por isso, me ative aos textos que indicavam as praias e seus municípios, visto um mesmo nome de praia ocorrer em municípios diferentes. Foram acrescidos a essa lista os locais relacionados aos desembarques ainda presentes na memória dos moradores locais. Em posse dessas informações, selecionei os pontos que seriam alvo de prospecções em superfície, objetivando avaliar os diversos compartimentos e eleger as variáveis que ratificariam ou refutariam a indicação de tais locais como associados aos desembarques de africanos escravizados. Essa prospecção foi eminentemente em superfície, visto a pesquisa não contar com autorização do Iphan para qualquer tipo de intervenção. Nesse sentido, foram realizados caminhamentos orientados nos segmentos praiais, que objetivaram inicialmente o registro fotográfico, videográfico e a localização de rios e riachos que desembocavam nas praias. Abarcaram também a observação das condições de mar e das variáveis de relevo, inclusive, avaliou-se brevemente os compartimentos topográficos a fim de entender como pode ter se dado a apropriação das áreas do entorno, na realização dos eventuais desembarques. 
Foram também realizadas conversas com moradores de comunidades tradicionais e de comunidades quilombolas, objetivando a obtenção de informações relativas ao período da escravidão, principalmente aquelas relacionadas aos possíveis locais de desembarque. Ainda foram feitos os registros das coordenadas de referências dos locais alvo de prospecções e das visitas técnicas realizadas as comunidades quilombolas e tradicionais (Prancha 10).

$\mathrm{Na}$ figura abaixo (Figura 9), pode-se observar de maneira mais clara um esquema das engrenagens utilizadas na presente pesquisa. É importante ressaltar que não existiu uma ordem definida, pois, conforme as informações eram obtidas, o ciclo poderia mudar de sentido ou de ordem.

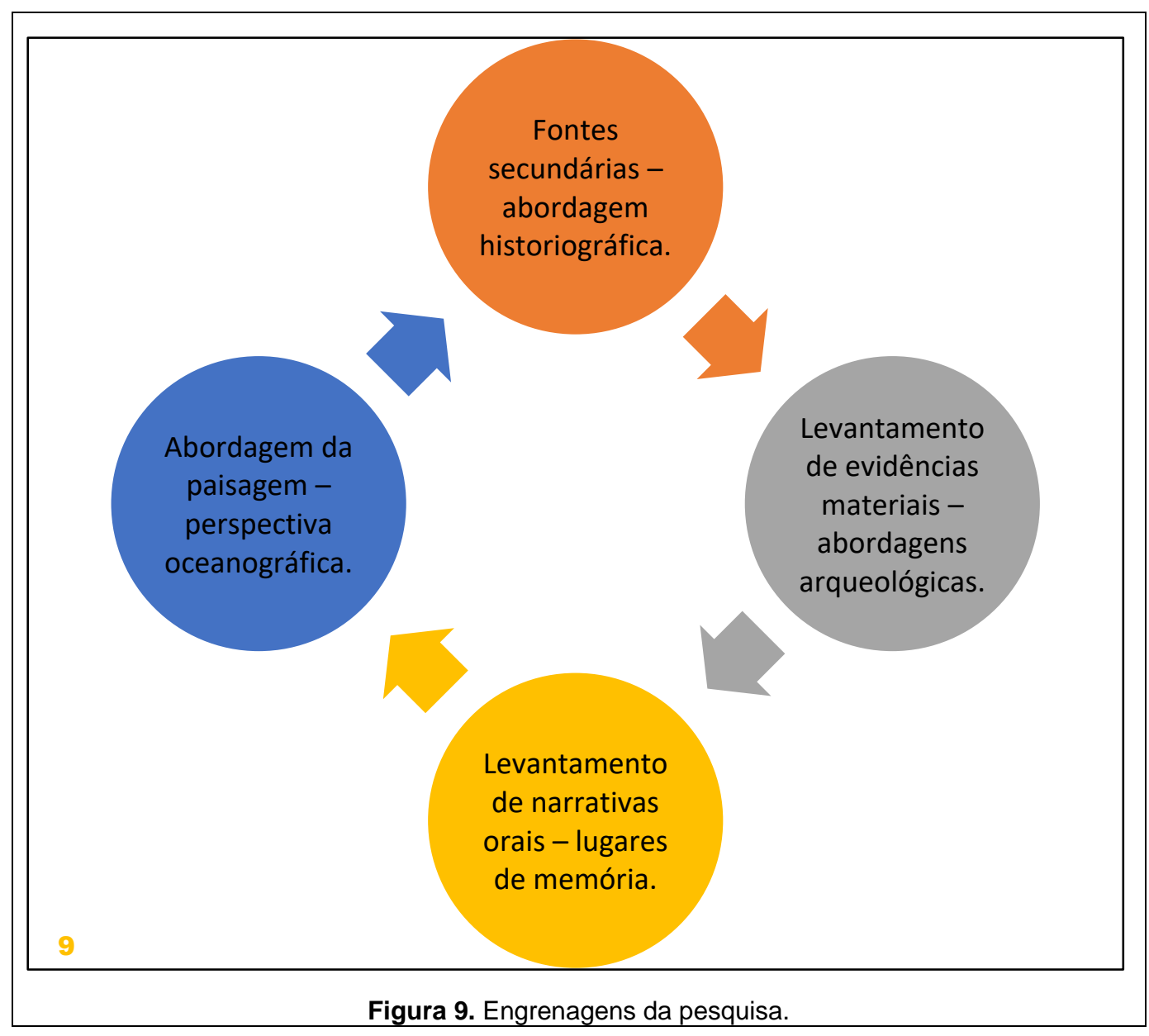




\section{PRANCHA 10. Procedimentos metodológicos adotados}
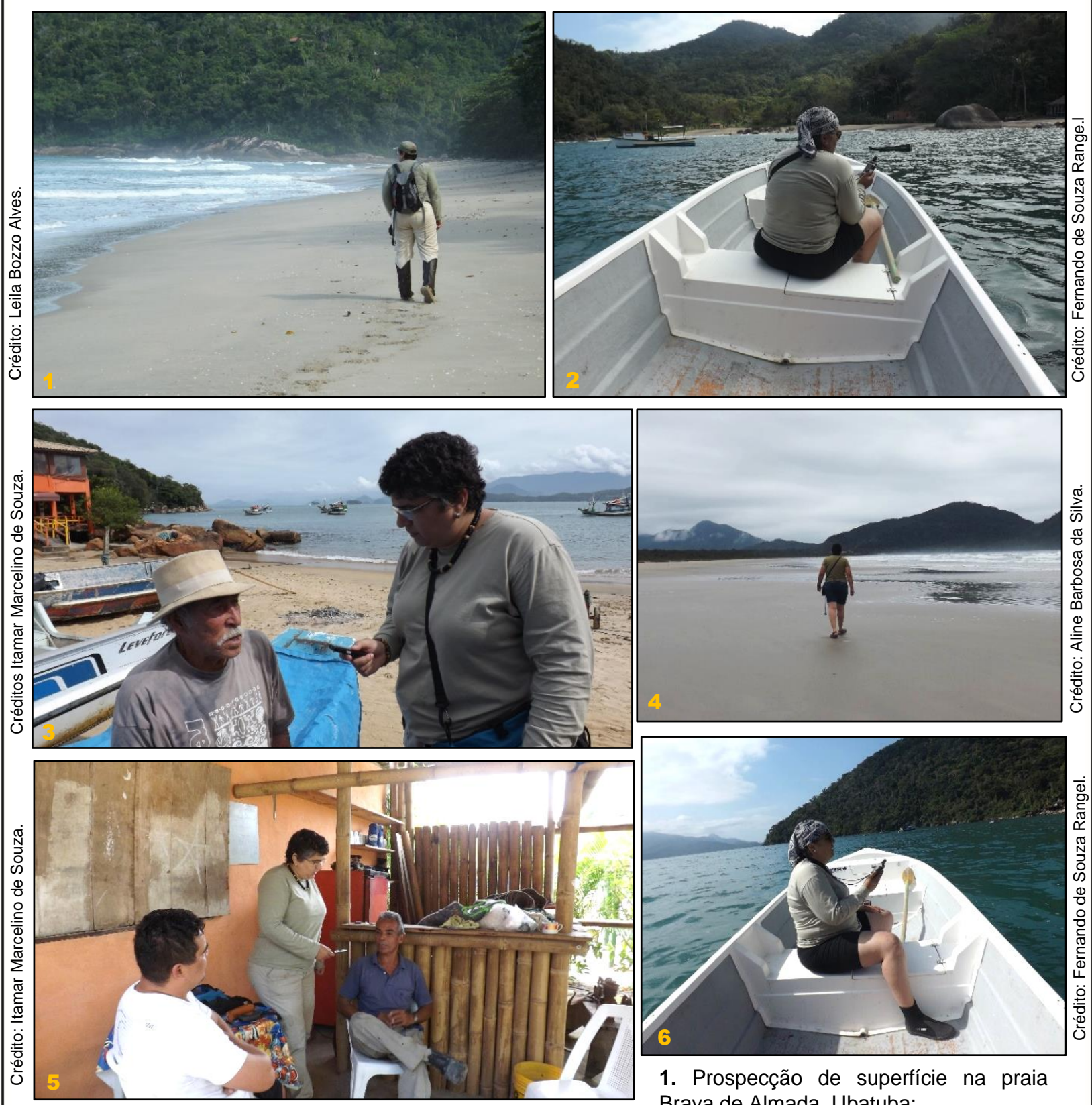

1. Prospecção de superfície na praia Brava de Almada, Ubatuba;

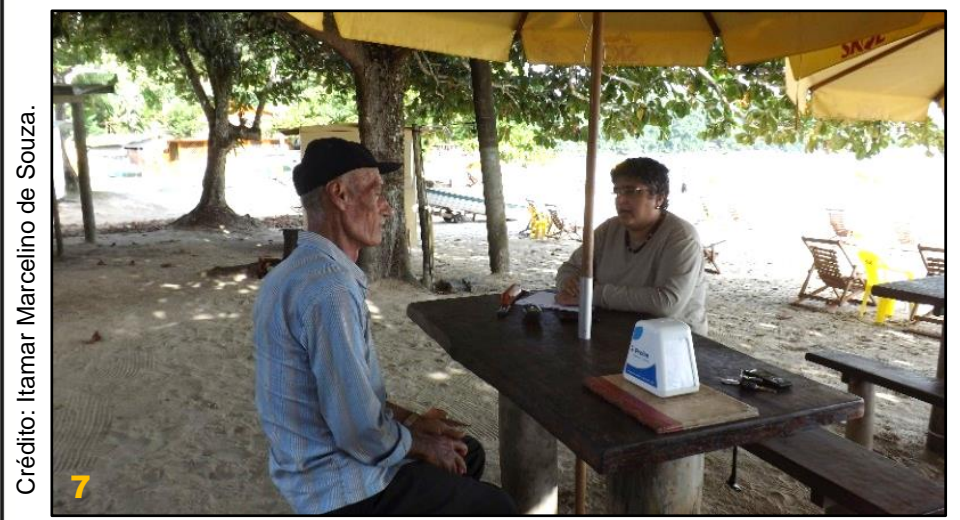

2. Tomada de pontos na "boca" do saco do Sombrio, Ilhabela;

3. Entrevista com Benedito Correia da Silva (seu Pú) na praia de Picinguaba, Ubatuba;

4. Prospecção de superfície na praia de Boraceia, São Sebastião;

5. Entrevista com Eliezer Soares e Celso Calos Firmino Soares, na praia de Camburi, Ubatuba;

6. Tomada de pontos no canto noroeste da praia da Figueira, Ilhabela;

7. Entrevista com Benedito da Conceição (seu Dico) na praia de Almada, Ubatuba.

Dissertação de Mestrado

A Diáspora Africana no litoral Norte paulista:

desafios e possibilidades de uma abordagem arqueológica. 
Depois de uma explanação das características gerais da área de estudo e dos principais mecanismos envolvidos no tráfico de africanos escravizados, elenco as possiblidades de abordagens arqueológicas ou etnoarqueológicas em contextos relacionados a diáspora africana, de acordo com os compartimentos de paisagens identificados na área de estudo:

$>$ Em ambiente aquático:

> Naufrágios de embarcações ${ }^{144}$ utilizadas no comércio/tráfico negreiro;

Evidências intencionalmente abandonadas ${ }^{145}$, como correntes, grilhões e outros itens que caracterizavam o tráfico de africanos;

Na zona entremarés:

Evidências diversas posicionadas intencional ou acidentalmente na interface água/terra;

$>\quad$ No ambiente terrestre:

> Antigas Fazendas de cana-de-açúcar e café;

$>$ Engenhos de açúcar e aguardente;

$>$ Vestígios das estruturas de recepção de africanos durante o período da ilegalidade;

$>$ Abrigos naturais apropriados como refúgio por africanos durante a vigência do sistema escravista;

$>$ Comunidades quilombolas.

A partir desse leque de possibilidades, os desafios impostos são muitos e se dão a princípio pelo grau de dificuldade na identificação de alguns desses tipos de evidências. A grosso modo, algumas tipologias apresentam maior facilidade de serem identificadas e acessadas que outras. Num primeiro grupo eu abarcaria as antigas fazendas de cana-de-açúcar e café, os engenhos de açúcar e aguardente e as comunidades quilombolas. Todas essas evidências estão no ambiente terrestre e o acesso a elas pode ser feito, na maioria das vezes, sem grandes dificuldades.

\footnotetext{
144 Nessa categoria são consideradas várias tipologias de embarcações, desde aquelas dedicadas à travessia transoceânica - como os brigues, bergatins e galeões, entre outros, - como também as pequenas embarcações a remo que faziam o apoio ao desembarque levando os cativos até as praias.

145 As evidências aqui referidas serão detalhadas no item 'Algumas possibilidades'.
} 
O outro grupo, se refere as evidências mais difíceis de serem identificadas e que dependem de outras variáveis que vão interferir de maneira direta na possibilidade de localização, identificação, formação e permanência do registro arqueológico. Incluiria nesse grupo os abrigos naturais apropriados como refúgios por africanos durante a vigência do sistema escravista, ou mesmo até os primeiros anos do pós-abolição. Em relação aos vestígios das estruturas de recepção para acomodar os africanos após os desembarques, entendo que essas evidências apresentam um grau de dificuldade ainda maior em relação a sua identificação e isso se deve, muitas vezes, a perecibilidade do material provavelmente utilizado nessas construções, que, na maioria dos casos, poderiam não resistir ao passar dos anos. Segundo Carvalho (2012), o "fim do tráfico liquidaria muitos negócios locais, vinculados aos inúmeros barracões para depósito de "africanos novos", que viriam a ser queimados pelas autoridades brasileiras encarregadas de exterminar o tráfico" (Op. Cit.:240). Ainda de acordo com o autor, as praias do tráfico encheram-se de barracões com a finalidade de receber os africanos recém desembarcados e, em muitos casos, eram estruturas impressionantes, aptas a receber centenas de pessoas de uma só vez (CARVALHO, 2012:246). Algumas evidências, anteriormente descritas como depositadas em ambiente submerso, podem ser localizadas também na zona entremarés e podem incluir vestígios associados a embarcações utilizadas no período da ilegalidade e que foram abandonadas ou incendiadas na praia, ou ainda, peças utilizadas para prender os africanos, tais como correntes, grilhões, gargalheiras, entre outros, que podem ter sido abandonadas nas praias após os desembarques e, com o passar do tempo, acabaram sendo enterradas na interface água/terra. Nesse sentido, as informações trazidas por Carvalho (2012) vêm de encontro ao potencial atribuído a zona entremarés, quando indica que nos anos finais do tráfico negreiro, embarcações cada vez menores eram utilizadas na travessia para buscar os africanos. De acordo com o autor, há registro de uma viagem feita por uma embarcação que, de tão pequena que era, nem nome tinha, mas, atravessou o atlântico apenas com o mestre e dois tripulantes, trazendo a bordo 42 cativos, sendo que desses, 36 sobreviveram a viagem e, com isso garantiram, o lucro da empreitada. Para o autor, "barcos assim poderiam ser levados até encalhar na praia, sendo abandonados ou destruídos após o desembarque, sem o mesmo custo da perda de uma embarcação de maior tonelagem (CARVALHO, 2012:234). 
Para o caso das evidências localizadas em ambiente aquático, além dos sítios de naufrágios de embarcações utilizadas no comércio/tráfico negreiro, podem também ser consideradas os objetos utilizados para aprisionar os africanos. Nesse contexto, pode-se considerar inclusive a grande quantidade de recipientes usados para estocar água e alimentos que, na intenção de eliminar as "provas do crime", eram descartados no mar, enquanto estavam atracadas (CARVALHO, 2012). Essas evidências eram jogadas mar para que a embarcação pudesse dar entrada no porto e ser abastecida com produtos tropicais para retornar a Europa. Essas embarcações são as mais difíceis de serem identificadas devido a necessidade de se encontrar detalhes construtivos e, possíveis arranjos internos que possam ser associados ao transporte de africanos. Como o caso de escotilhas gradeadas, grande quantidade de lastro, entre outros.

Nesse sentido, Feinman (1997, apud AGOSTINI, 2009) alerta que o cruzamento de informações empíricas extraídas de fontes distintas é uma estratégia metodológica tão fértil quanto perigosa no desenvolvimento de estudos interdisciplinares. $O$ autor ainda chama a atenção para um descuido metodológico de alguns arqueólogos ao fazerem uso de fontes documentais e de alguns historiadores com o uso das evidências arqueológicas, destacando que todo corpo de dados é uma construção do pesquisador, realizada para finalidades específicas e a partir de abordagens particulares. Devendo assim ser trabalhadas de maneira independente e que as informações obtidas possam ser justapostas e não sobrepostas, atribuindo veracidade as informações geradas.

Da mesma forma que Feinman (1997, apud AGOSTINI, 2009) chama a atenção para o cruzamento de informações dos textos historiográficos com as evidências arqueológicas, Funes (1997) também alerta para o cuidado que exige a documentação escrita e, além disso, chama a atenção para o risco de trabalhar com fontes orais,

(...) sejam elas depoimentos, entrevistas, histórias de vidas, canções, lendas, é um desafio que não assusta aqueles que percebem a sua importância, não apenas para conhecer a cultura de uma sociedade, mas o que se pode construir, a partir delas para o conhecimento do processo histórico. Sem dúvida, devemos ter cuidado ao trabalhar com essa tipologia de fontes, mas a documentação escrita também não exige precauções? Não se trata de saber qual que é mais confiável, a que garante mais informações e, sim, de 
perceber que as fontes orais abrem novas possibilidades para olhar 0 passado (FUNES, 1997:139).

Além das fontes historiográficas e orais, os parâmetros oceanográficos, ainda que de maneira mais genérica, foram utilizados na leitura do componente aquático e de sua interface com a costa e, colaboraram com variáveis importantes na composição do "cenário ideal" para os desembarques foram dos portos tradicionais. Da mesma forma que os compartimentos paisagísticos foram considerados, tanto com aspectos relativos ao relevo e à geomorfologia, por exemplo, quanto em relação à percepção de que esse conjunto de fatores podem ou não atribuir aos indivíduos envolvidos ${ }^{146}$, a sensação de "segurança" em relação a prática do ato ilícito.

Dessa forma, entendo que os municípios alvo de pesquisa testemunharam por dezenas de anos os desembarques de africanos e, nesse sentido, podem ser portadores de informações relevantes para a Arqueologia, principalmente por causa de sua inserção na interface terra/água, por isso, compactuo com Cruz, quando afirma que o litoral "possibilita vários tipos de estudos, pois é uma área essencialmente dinâmica passível de modificações, tanto lentas como rápidas, no espaço e no tempo" (1974:9). Essas modificações podem sugerir possibilidades de abordagens arqueológicas para a zona entremarés, por exemplo, conforme já apontada no item 4.2.2.

De acordo com Jaime Rodrigues (2005a) durante a ilegalidade do tráfico, os pontos mais distantes do litoral acabaram sendo preferidos pelas embarcações que transportavam os africanos. Isso se dava pela dificuldade imposta aos cruzadores ingleses que perseguiam as embarcações suspeitas, pois a boca dos rios, enseadas e pequenas baías proporcionavam refúgio temporário das embarcações inglesas e de quem sabe, patrulhas brasileiras.

Para Carvalho (2012), das várias atividades praticadas nos pontos de desembarques, é preciso

(...) incluir os cuidados com o próprio navio que teria que ser preparado para navegar até o porto oficial mais próximo, onde receberia passaporte e seria aprestado para outras aventuras mercantis, quem sabe até outra viagem à África. Não bastava livrar-se de correntes e outros equipamentos próprios do tráfico que poderiam chamar a atenção das autoridades no porto legal de destino (CARVALHO, 2012: 247).

146 Nesse caso, considero apenas a tripulação das embarcações negreiras, visto que para os africanos a situação em mar ou em terra era constantemente de insegurança e medo. 
Como se observa nas palavras de Carvalho (2012), o ato de se livrar das correntes, grilhões, grande quantidade de recipientes para o armazenamento de alimentos e água, além de outros itens presentes nas embarcações e característicos ao tráfico negreiro, acaba criando uma possibilidade de abordagem arqueológica desses itens, que podem ter sido descartados no local de atracamento das embarcações (nesse caso, estariam completamente submersos), ou terem sido parcialmente descartados no mar e em terra na chegada do africanos à praia (podendo ainda estar enterrados na zona entremarés).

O ato de livrar-se das evidências do tráfico também estava associado aos tipos de acordos firmados com os proprietários das terras que davam acesso aos pontos utilizadas nos desembarques e com a população local envolvida no apoio aos negreiros, além daqueles responsáveis pelas estruturas em terras preparadas para receber os africanos, pois, segundo Carvalho (2012),

\section{Para os traficantes, não havia outro caminho, ou tinham acesso aos melhores portos naturais próximos dos centros de consumo da mercadoria contrabandeada, ou saíam do negócio. Quanto melhor o porto natural, quanto mais pronta e segura a estrutura de recepcão, mais rápido, discreto e bem- sucedido o desembarque (CARVALHO, 2012: 256, grifo meu)}

A qualidade das estruturas de recepção, aqui apontadas como "mais pronta e segura", também era, segundo o autor, considerada no momento da escolha dos locais para os desembarques.

Outro fator importante, relacionado principalmente às condições climáticas e de navegabilidade, era a sazonalidade, considerada para os desembarques fora dos portos convencionais. De acordo com Florentino (2008), ela atendia a uma "lógica empresarial escravista", sendo mais frequentes na primavera e no verão, com pico no verão.

A escolha do local, além da proximidade do centro de consumo, distância dos núcleos urbanos, também levava em consideração as condições marítimas (marés, correntes de superfície, bancos de areia, presença de arrecifes, correntes costeiras, etc.), variáveis ambientais, como o relevo, pois era necessário permitir a instalação de estruturas de recepção e existir no local fontes de água doce acessíveis, a fim de promover o restabelecimento dos africanos que chegavam debilitados e doentes evitando, assim, possíveis prejuízos. Após o restabelecimento dos africanos, deveria se considerar a vegetação e o terreno que deveriam ser vencidos para que chegassem 
até o ponto de destino, que podia ser um comprador específico ou até um ponto de venda, onde vários compradores teriam acesso aos "escravos novos". Todos esses fatores tinham influência direta na dinâmica do tráfico em si.

Nesse sentido, foram realizadas conversas com integrantes das comunidades quilombolas e com alguns moradores das praias de Picinguaba, Almada, Brava de Almada e Camburi, em Ubatuba; da praia dos Castelhanos, em Ilhabela; e das praias de Toque Toque Grande e Barra do Saí, em São Sebastião. Esses diálogos permitiram a obtenção de informações que os remetem aos desembarques de africanos na região.

$\mathrm{Na}$ tabela abaixo são apresentados os locais identificados, como tendo sido possivelmente utilizados para o desembarque de africanos. Conforme já apontado, a indicação desses locais foi fomentada pelos textos historiográficos e pelas informações orais, conforme se observa na tabela 4. As fontes consultadas para a elaboração dessa tabela se encontram no anexo 1.

Tabela 4. Possíveis locais de desembarques e seu status.

\begin{tabular}{|c|c|c|c|c|}
\hline \multirow{2}{*}{$\begin{array}{c}\text { Local indicado como possível ponto } \\
\text { de Desembarque }\end{array}$} & \multirow{2}{*}{ Município } & \multirow{2}{*}{$\begin{array}{c}\text { Alvo de } \\
\text { prospecção }\end{array}$} & \multicolumn{2}{|c|}{ Fontes consultadas } \\
\hline & & & Texto Hist. & Inf. Ora \\
\hline Ilha dos Porcos & Ubatuba & & & $x$ \\
\hline Praia da Lagoinha & Ubatuba & $x$ & $x$ & \\
\hline Praia da Maranduba & Ubatuba & $x$ & $x$ & \\
\hline Praia do Bonete & Ubatuba & & $\mathrm{X}$ & \\
\hline Praia da Caçandoca & Ubatuba & $x$ & $x$ & $x$ \\
\hline Praia da Barra Seca & Ubatuba & $\mathrm{X}$ & $x$ & \\
\hline Praia de Ubatumirim & Ubatuba & $x$ & $x$ & $x$ \\
\hline Praia de Picinguaba & Ubatuba & $x$ & & $x$ \\
\hline Praia da Fazenda & Ubatuba & $x$ & & $x$ \\
\hline Ilha do Prumirim & Ubatuba & & & $x$ \\
\hline Praia da Fortaleza & Ubatuba & $x$ & $\mathrm{X}$ & \\
\hline Ilha do Tamanduá & Caraguatatuba & & $\mathrm{x}$ & \\
\hline Praia da Tabatinga & Caraguatatuba & $x$ & $x$ & \\
\hline Praia de Toque Toque Grande & São Sebastião & $x$ & $\mathrm{X}$ & $x$ \\
\hline Praia da Barra do Sahy & São Sebastião & $x$ & $x$ & \\
\hline Praia da Barra do Una & São Sebastião & $\mathrm{X}$ & $\mathrm{X}$ & \\
\hline Praia de Boracéia & São Sebastião & $x$ & $x$ & \\
\hline Praia dos Castelhanos & Ilhabela & $x$ & $\mathrm{X}$ & $x$ \\
\hline Praia da Figueira & Ilhabela & $x$ & $x$ & \\
\hline Saco do Sombrio & Ilhabela & $x$ & $x$ & $x$ \\
\hline
\end{tabular}


Depois de identificados os possíveis locais de desembarques, alguns foram selecionados a fim de serem realizadas prospecções em superfície, objetivando o recobrimento de todo o segmento praial. Com exceção da praia do Bonete, em Ubatuba, as demais praias continentais indicadas foram alvo de prospecções em superfície. As praias localizadas em ilhas (Ilha dos Porcos e llha do Prumirim, em Ubatuba, e Ilha do Tamanduá, em Caraguatatuba) não foram selecionadas para as prospecções de superfície porque a orientação das praias atribuía a elas um caráter abrigado, o que não alteraria, a princípio, a leitura realizada do viés oceanográfico.

Nesse sentido, a prancha 11 exibe todos os onze pontos associados aos desembarques de africanos localizados em Ubatuba. A partir da prancha 12 até a 19, são apresentados os oito locais (praia de Picinguaba, praia da Fazenda, praia de Ubatumirim, praia da Barra Seca, praia da Fortaleza, praia da Lagoinha, praia da Maranduba e praia da Caçandoca) que foram alvo de prospecções e, por isso, possibilitaram uma descrição mais detalhada.

Na prancha 20, o município de Caraguatatuba é exibido com a indicação dos dois pontos associados aos desembarques de africanos. Nesse município, conforme exposto anteriormente, somente o ponto associado ao desembarque localizado no continente foi alvo de prospecções, sendo que os resultados dessas ações na praia da Tabatinga são apresentados na prancha 21.

Todos os locais associados ao desembarque de africanos escravizados localizados no município de São Sebastião foram alvo de prospecções de superfície, cujos resultados são apresentados nas pranchas 22 a 26.

O município de llhabela só teve locais associados ao desembarque de africanos em sua porção leste, mais especificamente na baía dos Castelhanos. Nesse sentido, nas pranchas $\mathbf{2 7}$ a $\mathbf{3 0}$ há os resultados dessas prospecções.

Vale lembrar que, nas pranchas onde são apresentados os locais indicados como ponto de desembarques clandestinos e que foram alvo de prospecções em superfície, sempre que for mostrada uma imagem da praia, aparecerá a informação relativa à estação do ano e à fase da lua. Essas informações foram extremamente relevantes para as observações empíricas, principalmente as fases da lua, visto que estão associadas aos movimentos de maré, a saber: maré de quadratura, acontecem nos períodos de quarto minguante e quarto crescente e são marés de pequena 
amplitude; maré de sizígia, acontecem nos períodos de lua nova e lua cheia e são as marés de maiores amplitudes e produzem as maiores marés altas e as menores marés baixas. Dependendo da região, alteram significativamente a leitura dos componentes oceanográficos pois podem gerar mudanças significativas, tanto em redução quanto em aumento das faixas de areia, por exemplo. 
PRANCHA 11. Locais utilizados como pontos de desembarques - Ubatuba

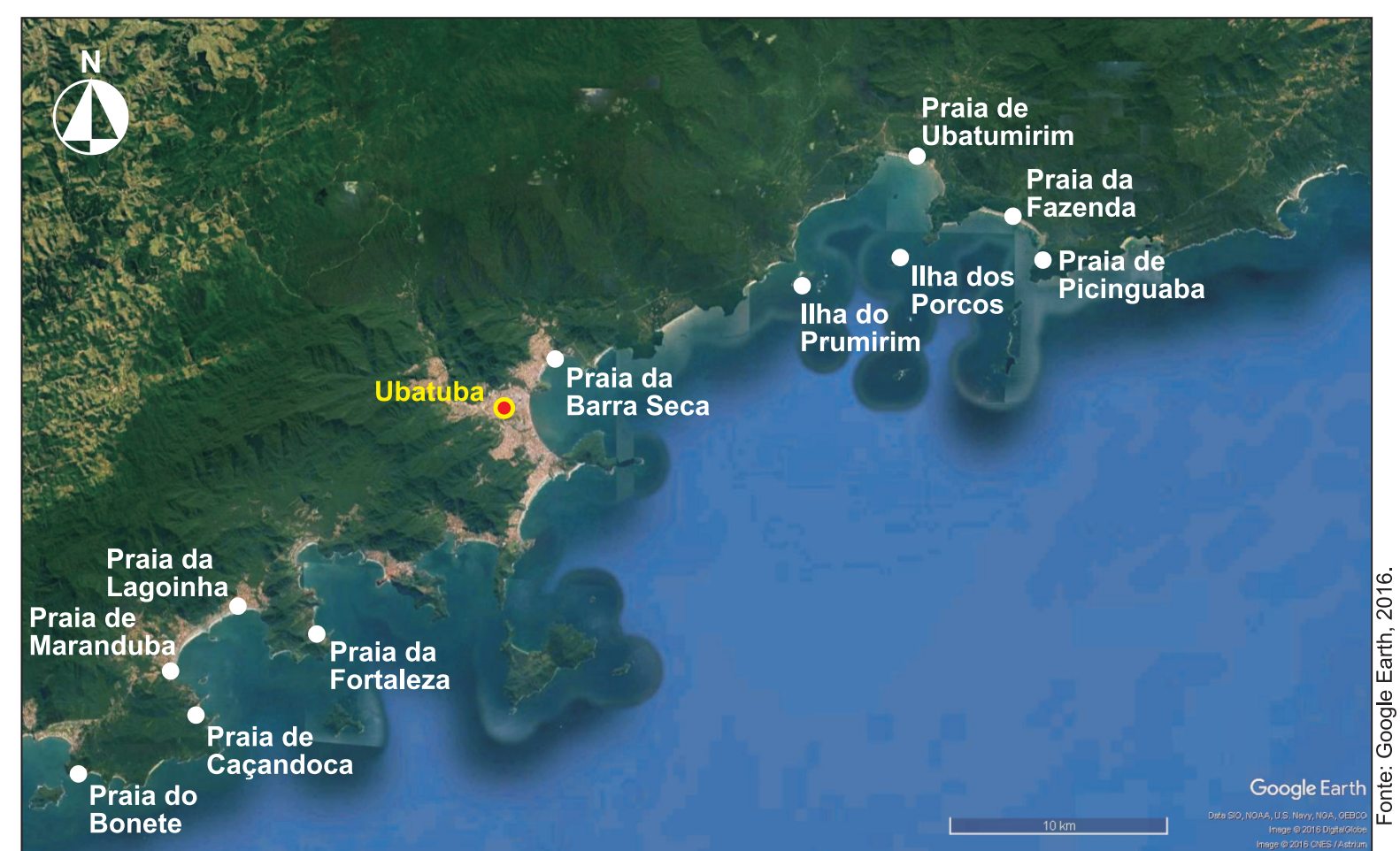

A imagem acima apresenta o município de Ubatuba com a espacialização de todos os locais indicados como pontos de desembarques clandestinos

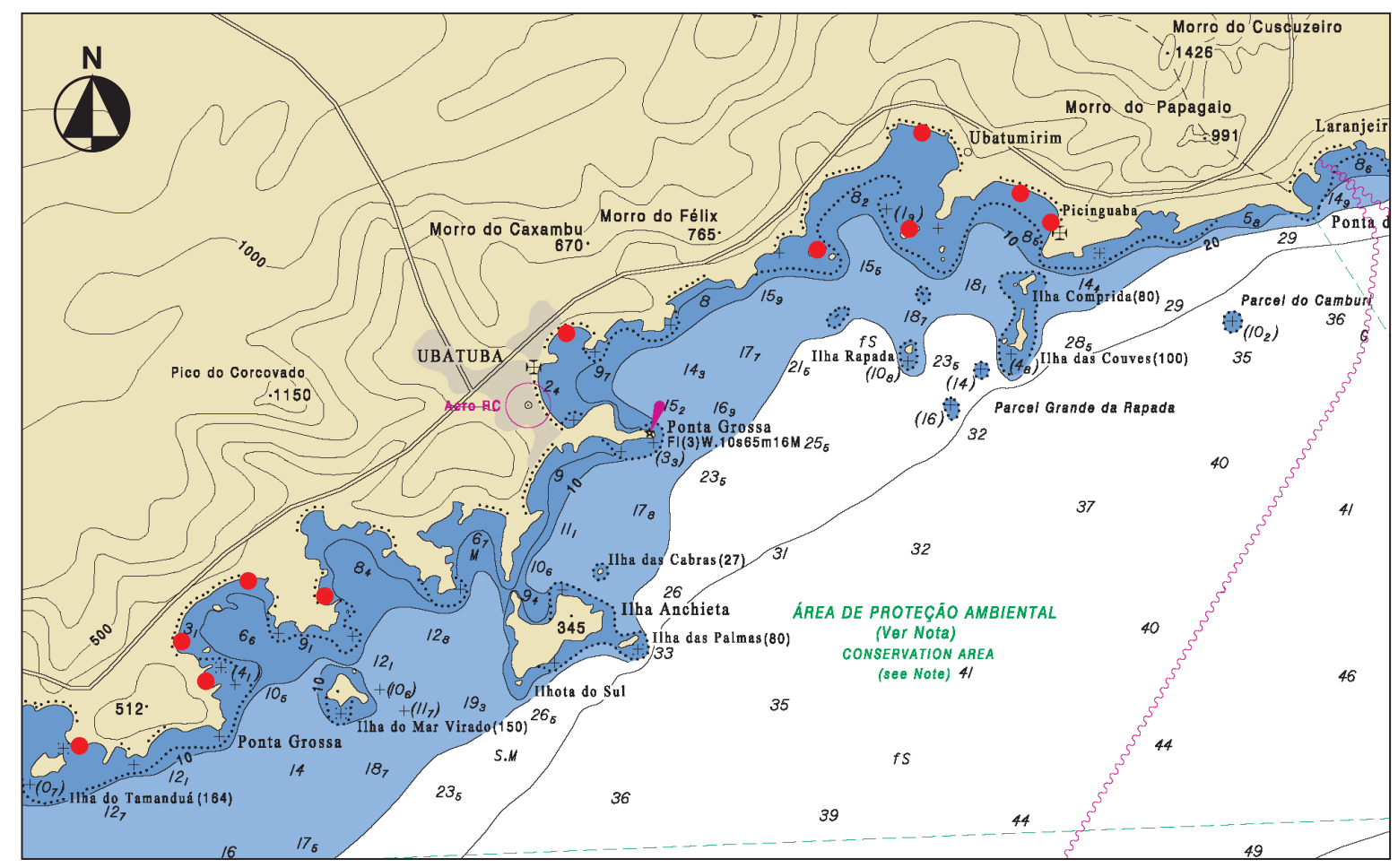

Acima um recorte da Carta Náutica (CARTA NÁUTICA 2310023100 - INT.2124) com todos os locais indicados como pontos de desembarque no município de Ubatuba. A inserção deste recorte se dá a partir de uma perspectiva de quem chega pelo oceano, com os obstáculos naturais, marcadores na paisagem, variações de profundidades, correntes, ventos, etc. Para Ubatuba, em função de seu litoral repleto de reentrâncias, formando enseadas, os desafios impostos às embarcações são maiores ainda.

Além de terem de vencer as correntes oceânicas, as correntes costeiras podem interferir no ritmo e precisão das aproximações para os desembarques.

Dissertação de Mestrado

A Diáspora Africana no litoral Norte paulista: desafios e possibilidades de uma abordagem arqueológica. 


\section{PRANCHA 12. Praia de Picinguaba}
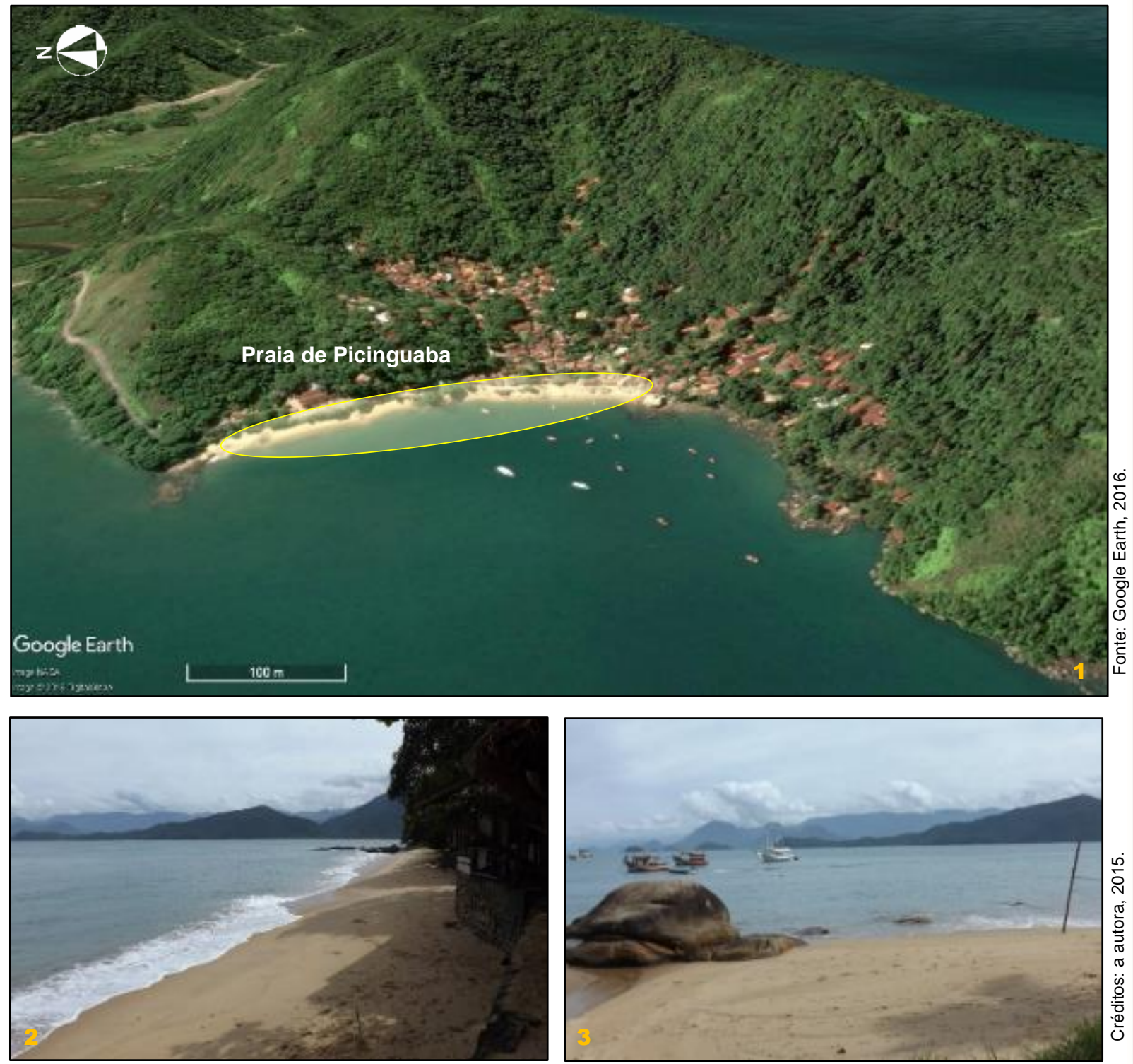

A praia de Picinguaba está inserida na enseada homônima, distante, aproximadamente, 40 quilômetros do núcleo urbano de Ubatuba e possui perto de 400 metros de extensão (Imagem 1). É uma praia de águas calmas, quase sem ondas em condições meteorológicas normais, conforme se observa nas imagens 2 e 3, em registro feito no outono de 2015 (fase da lua - quarto minguante). A declividade da plataforma continental é suave e a profundidade na enseada chega aos 10 metros já na "boca" (média da baixa mar de sizígia) (CARTA NÁUTICA 1635). Pode-se considerar que a praia acaba ficando protegida por causa da presença de várias ilhas na área, além de sua localização não formar um ângulo direto como o "mar de fora". Como se observa na imagem 3, pequenas embarcações utilizam a área em frente a praia para o atracamento, situação que pode ter acontecido no período da ilegalidade do tráfico. Apesar da pequena área plana se restringir às adjacências da faixa de areia, a declividade do morro tem crescimento lento nos primeiros metros, o que poderia permitir a construção de estruturas de recepção a fim de abrigar os africanos recém chegados. Há referências de que, no século XIX, inúmeros engenhos existiam na área e a presença de fonte de água doce nas proximidades é outro fator a ser considerado como importante na escolha dos pontos. A distância do centro urbano de Ubatuba por si só já é um fator considerável, pois evitaria possíveis visualizações por terra. No entanto, a presença de outra praia na mesma enseada também associada aos desembarques clandestinos poderia ser um fator prejudicial, a não ser que a parceria fosse a mesma, caso contrário, as ações estariam expostas demais "aos inimigos". O relevo "afogado" da praia de Picinguaba, obriga atualmente a uma ocupação das encostas de maneira bastante peculiar, tendo sido, inclusive, parte das suas unidades habitacionais que estão localizadas de frente ao mar tombadas pelo CONDEPHAAT.

Dissertação de Mestrado

A Diáspora Africana no litoral Norte paulista: desafios e possibilidades de uma abordagem arqueológica. 


\section{PRANCHA 13. Praia da Fazenda}
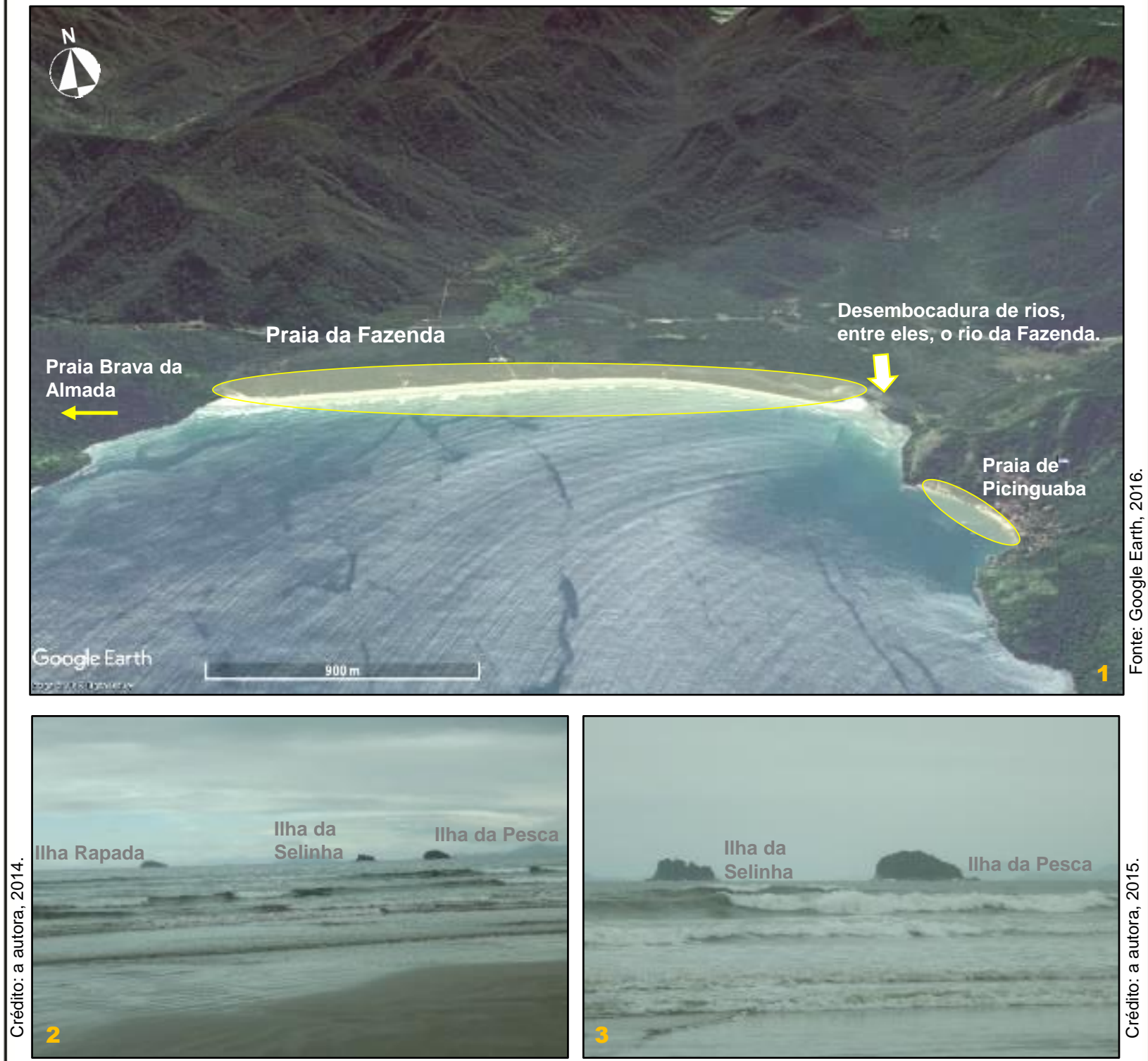

Localizada na enseada de Picinguaba, a praia da Fazenda tem pouco mais de três quilômetros de extensão e está a uma distância aproximada de 37 quilômetros do núcleo urbano de Ubatuba (Imagem 1). É uma praia que possui uma grande faixa de areia, com zona de arrebentação longa em condições meteorológicas normais. A imagem 2 foi obtida na primavera de 2014 (fase da lua - lua nova) e a imagem 3 foi no outono de 2015 (fase da lua - quarto minguante) e, apesar de ângulos diferentes, a imagem 3 apresenta ondas de maior altura, provavelmente associadas a mudanças nas condições climáticas. A declividade da plataforma continental é suave e a profundidade na enseada chega aos 10 metros já na "boca" (média da baixa mar de sizígia) (CARTA NÁUTICA 1635). Nas imagens 2 e 3 é possível observar ilhas que já estão fora da enseada, nesse sentido, a interferência que causam na chegada das ondas na praia e praticamente nula. Após a faixa de areia existe uma área plana bastante extensa, com distâncias até as primeiras escarpas da serra do mar que podem alcançar mais de dois quilômetros, onde correm vários rios, entre eles o rio da Fazenda que desemboca no canto leste da praia. Nessa planície não faltaria locais para instalação das estruturas de recepção, no entanto, é preciso considerar a existência no século XIX da Fazenda Picinguaba. Nesse sentido, o(os) proprietário(s) poderiam ou não estar envolvidos com a absorção da mão-de-obra africana, pois poderia somente ter arrendado o local para o desembarque. No entanto, essa praia tem como divisa oeste um morro que a separa da praia Brava de Almada. Mais adiante, serão apontadas possibilidades de que as ruínas lá encontradas poderiam ser das estruturas de recepção de africanos desembarcados na praia da Fazenda, visto uma rápida ligação por trás do morro. Da mesma forma que na praia de Picinguaba, o maior trunfo dos desembarques nessa praia é a distância do núcleo de Ubatuba e a enseada em que estão.

Dissertação de Mestrado

A Diáspora Africana no litoral Norte paulista: desafios e possibilidades de uma abordagem arqueológica. 


\section{PRANCHA 14. Praia de Ubatumirim}
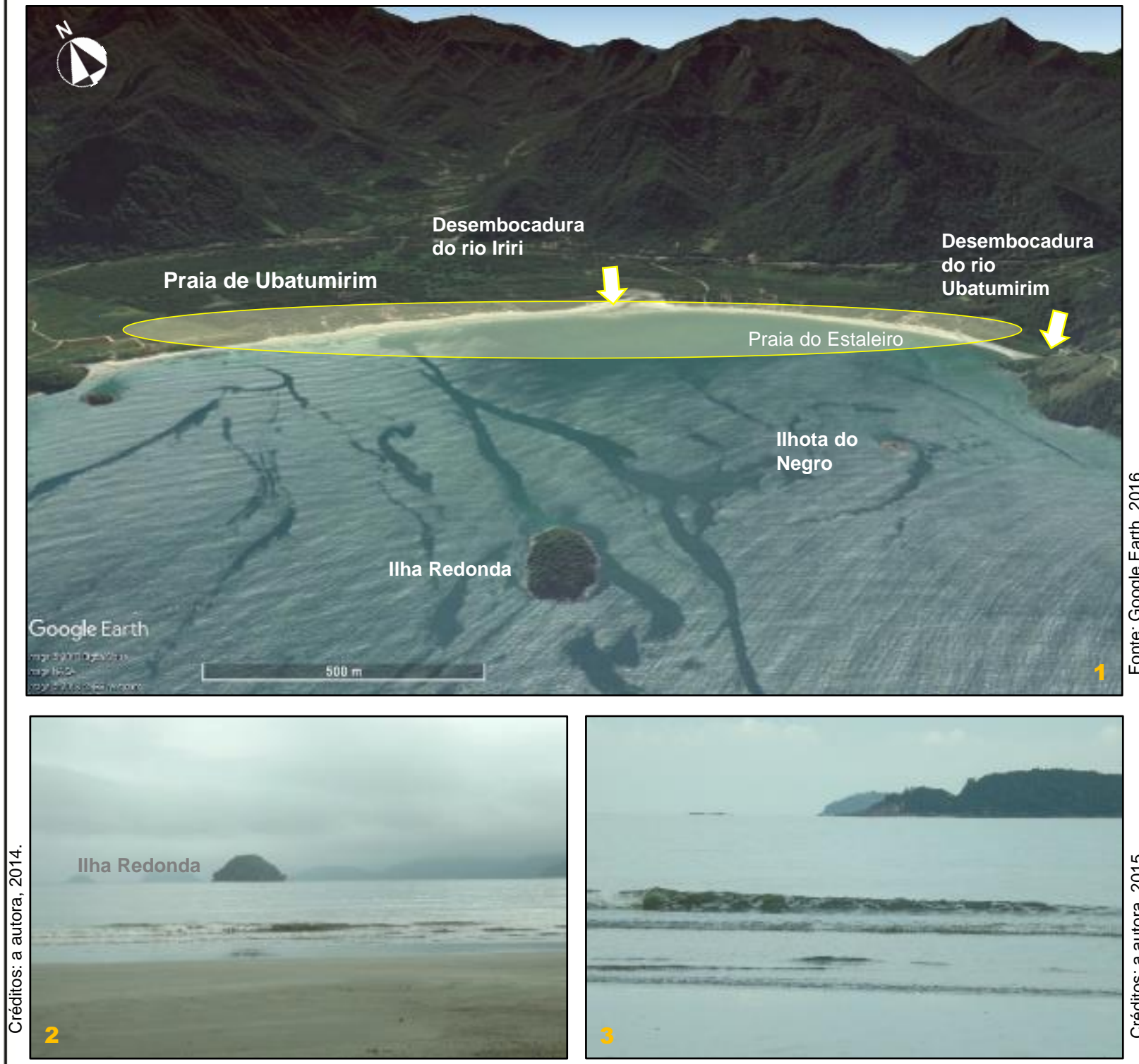

Na enseada Ubatumirim, está localizada, além da praia homônima, a praia da Justa. Com distância do núcleo urbano de Ubatuba na ordem de 33 quilômetros, a praia de Ubatumirim tem, aproximadamente, quatro quilômetros de extensão. Na imagem 1, é possível observar um grande segmento praial, que atualmente abarca duas praias: a praia de Ubatumirim e a praia do Estaleiro. No entanto, a atual divisão não está sendo considerada nesse trabalho, por entender que não há nenhuma divisão natural que justifique. A imagem 2 foi obtida na primavera de 2014 (fase da lua - lua nova) e a imagem 3 em outono de 2015 (fase da lua - quarto minguante) e, apesar de as estações serem diferentes, na imagem 3 praticamente não se percebe alterações significativas. Com uma plataforma de declividade bem suave, a profundidade na "boca" da enseada alcança cinco metros (CARTA NÁUTICA 1635), o que faz dessa enseada a menos profunda em relação as outras onde estão localizados os pontos de desembarques. Protegida pela ilha Redonda e devido a declividade da plataforma continental, quase não arrebentam ondas e, quando isso acontece, já é bem próximo da faixa de areia. Com uma área plana extensa, não faltariam opções para a instalação de estruturas de recepção, além do acesso rápido a fontes de água doce. Dificilmente essas terras teriam mais de um dono, o que faz desse ponto um local com alto potencial para que os desembarques tenham realmente acontecido. A distância em relação ao núcleo urbano, a tranquilidade da aproximação das embarcações até a boca da enseada, baixa dificuldade para os barcos menores que fariam o apoio aos negreiros e ausência direta de "vizinhos", além de uma ampla planície apta a abrigar estruturas de recepção, eram condições favoráveis para os desembarques clandestinos na praia de Ubatumirim.

Dissertação de Mestrado

A Diáspora Africana no litoral Norte paulista: desafios e possibilidades de uma abordagem arqueológica. 


\section{PRANCHA 15. Praia da Barra Seca}
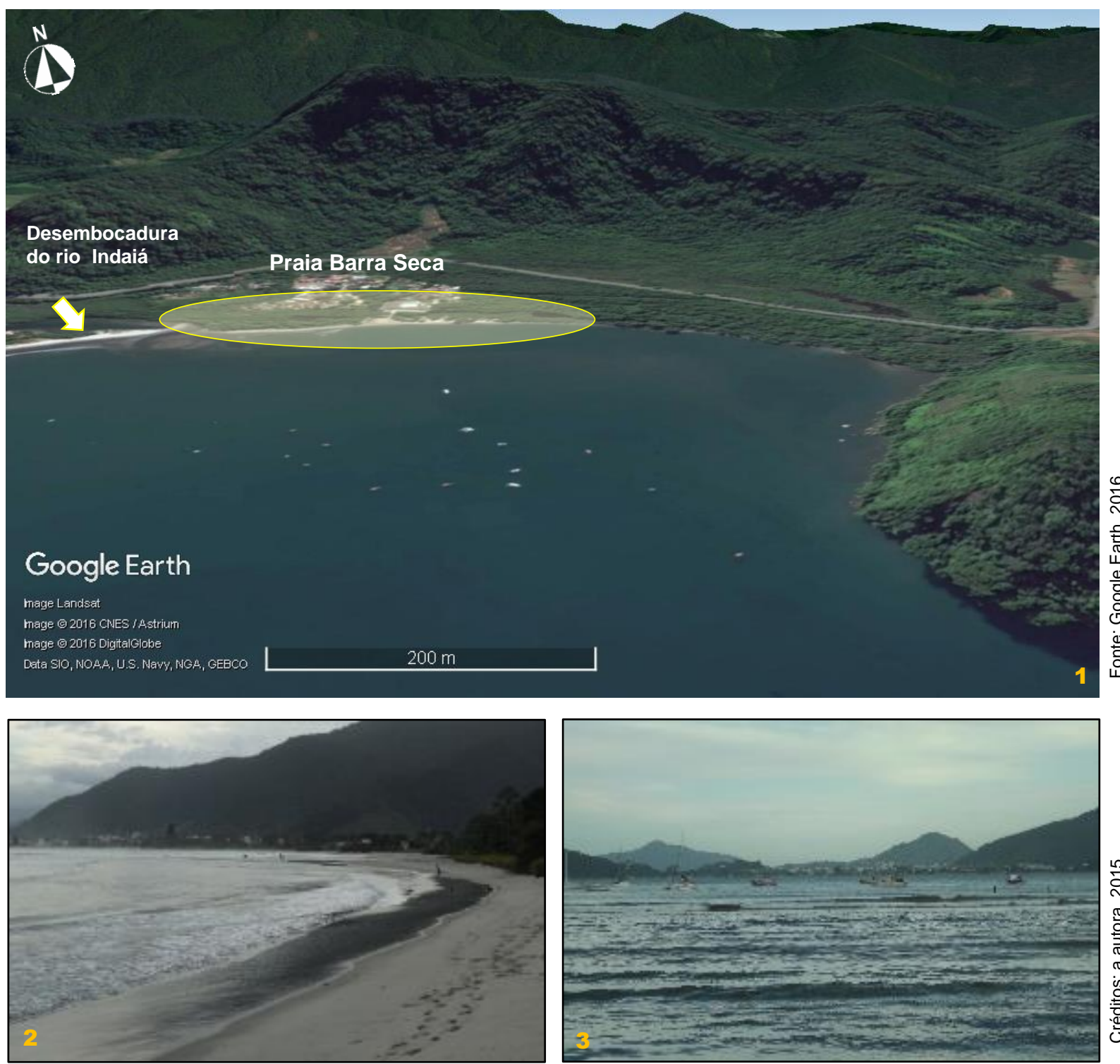

A praia da Barra Seca está localizada na enseada de Ubatuba, onde também está a praia de Itaguá e Iperoig, sendo que nessa última é onde funcionava o porto e onde, teoricamente, não eram mais realizados desembarques de africanos. Está distante pouco mais de três quilômetros do núcleo urbano de Ubatuba e possui aproximadamente 500 metros de extensão (Imagem 1). $O$ fato de um ponto de desembarque tão próximo assim dos pontos "vigiados" pode indicar maior deboche dos traficantes, o que necessitaria de maior habilidade e astúcia dos capitães das embarcações, caso fosse preciso uma fuga rápida. As águas calmas dessa enseada (Imagem 2, outono de 2015 - fase da lua - quarto minguante) podem estar associadas a declividade da plataforma continental, que vai angulando discretamente até alcançar os nove metros de profundidade na "boca" (CARTA NÁUTICA 1635). Com uma pequena planície encaixada entre o rio Indaiá a oeste e morros e leste, poderia facilmente acomodar estruturas de recepção para receber os africanos recém chegados. O rio Indaiá apresenta um volume hídrico razoável até os dias de hoje, tendo sido muito provavelmente utilizado por barcos menores que davam apoio aos negreiros no desembarque. Se a opção de seguir pelo rio para o desembarque for a seguida, a planície que o rio Indaiá percorre antes de alcançar o mar possui, aproximadamente, dois quilômetros antes da declividade começar a mudar por causa das proximidades das escarpas da serra do mar. As águas calmas dessa enseada, proporcionariam aproximação discreta das embarcações (Imagem 3, outono de 2015, fase da lua - quarto minguante). Depois de entrar na barra, caso avistamentos estivessem sendo feitos da terra a partir do porto de Ubatuba, as embarcações estariam em parte protegidas, devido a um morro que marca a divisa entre os dois segmentos praiais. Se a opção fosse o desembarque na praia da Barra Seca, as embarcações aportariam defronte a praia e o barcos menores fariam o transporte dos cativos até a praia.

Dissertação de Mestrado

A Diáspora Africana no litoral Norte paulista: desafios e possibilidades de uma abordagem arqueológica. 


\section{PRANCHA 16. Praia da Fortaleza}
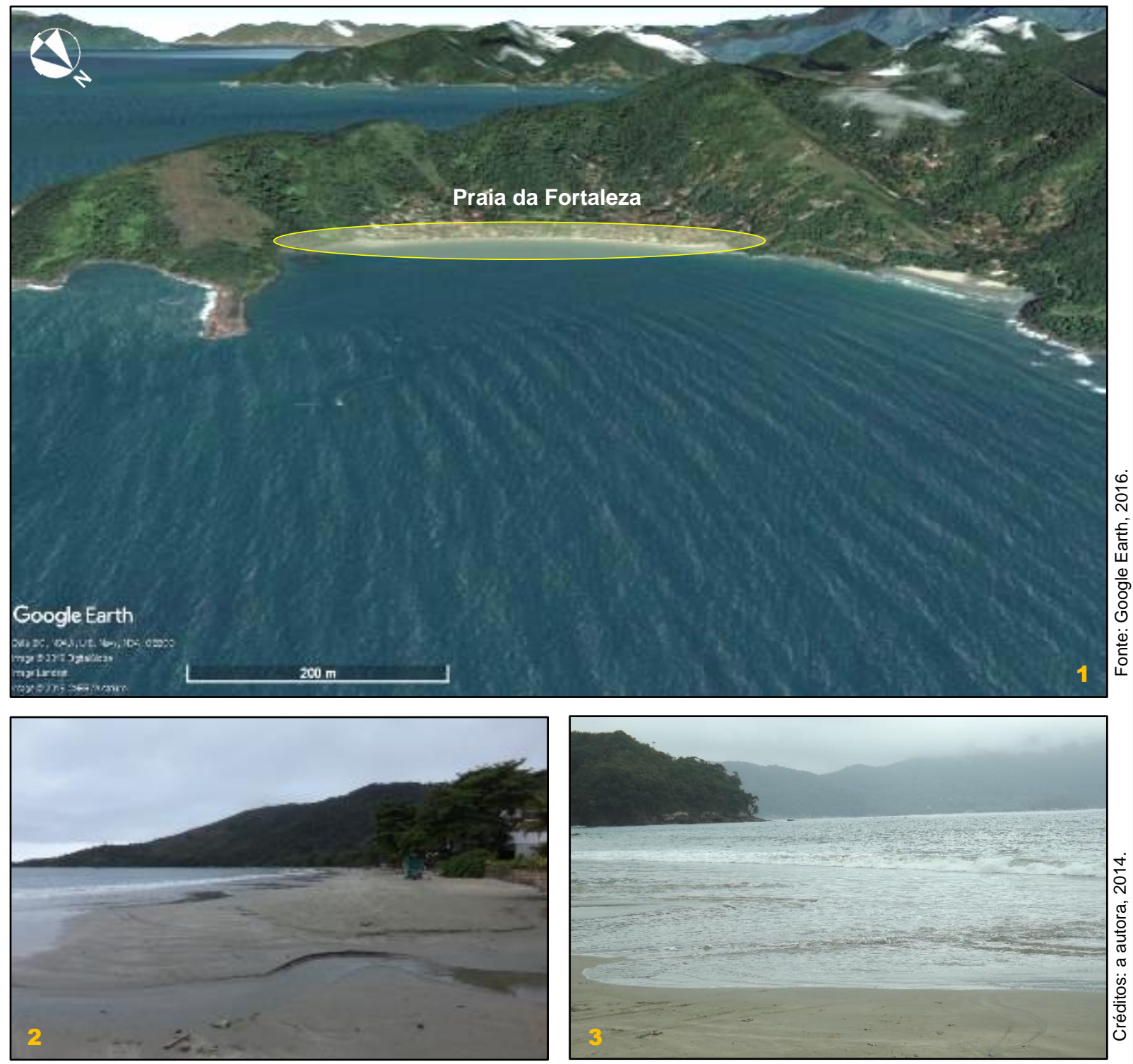

A praia da Fortaleza está inserida na enseada homônima e distante, aproximadamente, 17 quilômetros do núcleo urbano de Ubatuba, possui quase um quilômetro de extensão, sendo que seus limites norte e sul se dão por morros (Imagem 1). É uma praia de águas calmas, com ondas pequenas em condições meteorológicas normais, conforme se observa nas imagens 2 e 3, em registros obtidos na primavera de 2014 (fase da lua - lua nova). A declividade da plataforma continental é discretamente mais acentuada que a praia de Ubatumirim, por exemplo. A profundidade da enseada da Fortaleza não ultrapassa os 10 metros na "boca" (média da baixa mar de sizígia) (CARTA NÁUTICA 1635). Na área defronte a praia, após a arrebentação, a profundidade se acentua rapidamente, o que poderia ser uma condição positiva para a aproximação de embarcações em eventuais desembarques. Pequena área com declividade suave apresenta-se após a faixa de areia, o que permitiria a instalação de estruturas para receber os africanos recém desembarcados. Um pequeno riacho atualmente deságua na praia, mas antes da construção das casas da comunidade, muito provavelmente o volume hídrico era maior, o que possibilitaria o acesso a água potável imediatamente após o desembarque, além de que, dependendo desse volume, poderiam os barcos menores que dão apoio aos negreiros entrarem carregados e realizarem o desembarque as margens do riacho. A proximidade com a entrada da enseada faz da praia da Fortaleza um local bastante propício para o desembarque de africanos no período da ilegalidade. A distância em relação ao núcleo urbano, a profundidade de sua zona de surfe, a proximidade com a entrada da enseada, atribuem a praia da Fortaleza condições favoráveis para a recepção de africanos ilegalmente desembarcados durante o século XIX.

Dissertação de Mestrado

A Diáspora Africana no litoral Norte paulista: desafios e possibilidades de uma abordagem arqueológica. 


\section{PRANCHA 17. Praia da Lagoinha}
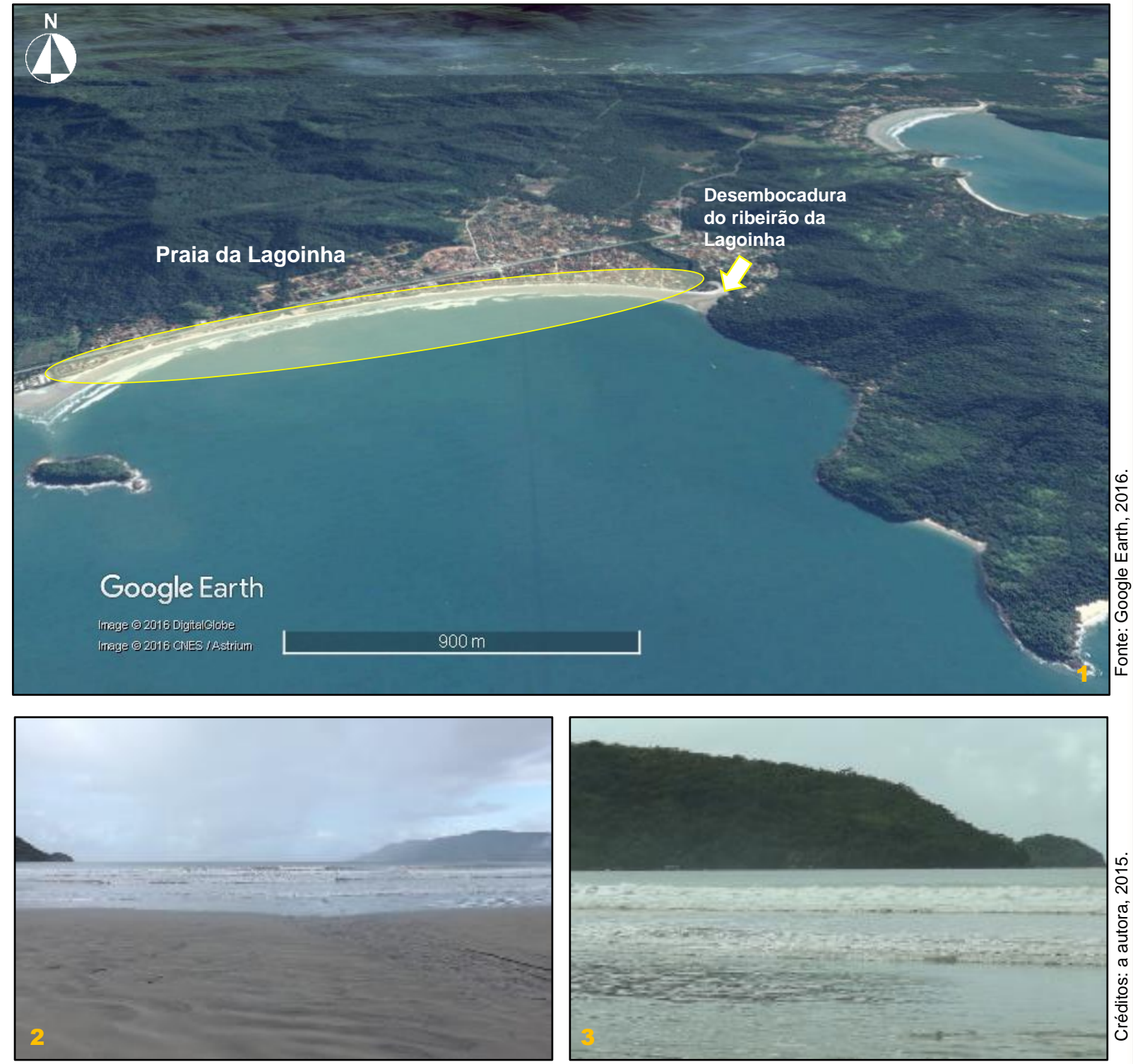

Localizada na enseada do Mar Virado, a praia da Lagoinha está distante, aproximadamente, 19 quilômetros do núcleo urbano de Ubatuba e tem uma extensão em torno de três quilômetros, fazendo divisa a oeste com a praia do Sapê e a leste com um morro (Imagem 1). É uma praia de águas calmas, com ondas pequenas em condições meteorológicas normais, conforme se observa nas imagens 2 e 3, em registro feito no outono de 2015 (fase da lua - quarto minguante). A declividade da plataforma continental é suave e a profundidade na enseada chega nos 10 metros já na "boca" (média da baixa mar de sizígia) (CARTA NÁUTICA 1635). A presença da ilha do Mar Virado já fora da enseada (distante seis quilômetros da praia da Lagoinha), pode servir como uma barreira e amenizar a intensidade das ondas que chegam à praia. Existe uma área plana que vai em direção as escarpas da serra do mar e que no sentido norte pode chegar a aproximadamente 2,5 quilômetros e que possibilitaria a instalação de estruturas de recepção. A presença do ribeirão da Lagoinha, no limite oeste entre a praia e o morro, possibilita o acesso à água potável a partir da praia. Apesar da indicação da praia da Lagoinha como possível local de desembarque de africanos, ela por si só não apresenta condições favoráveis a ser um ponto de desembarque, considerando as praias restantes na enseada como "território proibido". Para que se obtivesse sucesso em desembarques nessa praia, precisaria contar com o apoio dos proprietários das terras na enseada como um todo, visto que também existe a indicação do uso como pontos de desembarque nas praias da Maranduba e da Caçandoca, ambas na enseada do Mar Virado. A condição abrigada da enseada possibilita invisibilidade a partir do porto de Ubatuba de possível fiscalização. No entanto, para fiscalizações por água, sejam os cruzadores ingleses ou brasileiros, a baixa profundidade da enseada poderia impossibilitar o acesso de embarcações maiores e, com isso, evitar a apreensão.

\begin{tabular}{|l|l|}
\hline \multicolumn{2}{|c|}{ Dissertação de Mestrado } \\
\hline $\begin{array}{l}\text { A Diáspora Africana no litoral Norte paulista: } \\
\text { desafios e possibilidades de uma abordagem arqueológica. }\end{array}$ \\
\hline Aluna: Luciana Bozzo Alves \\
\hline Orientador: Prof. Dr. Pedro Paulo de Abreu Funari \\
\hline Museu de Arqueologia e Etnologia / USP & dez/16 \\
\hline
\end{tabular}




\section{PRANCHA 18. Praia da Maranduba}
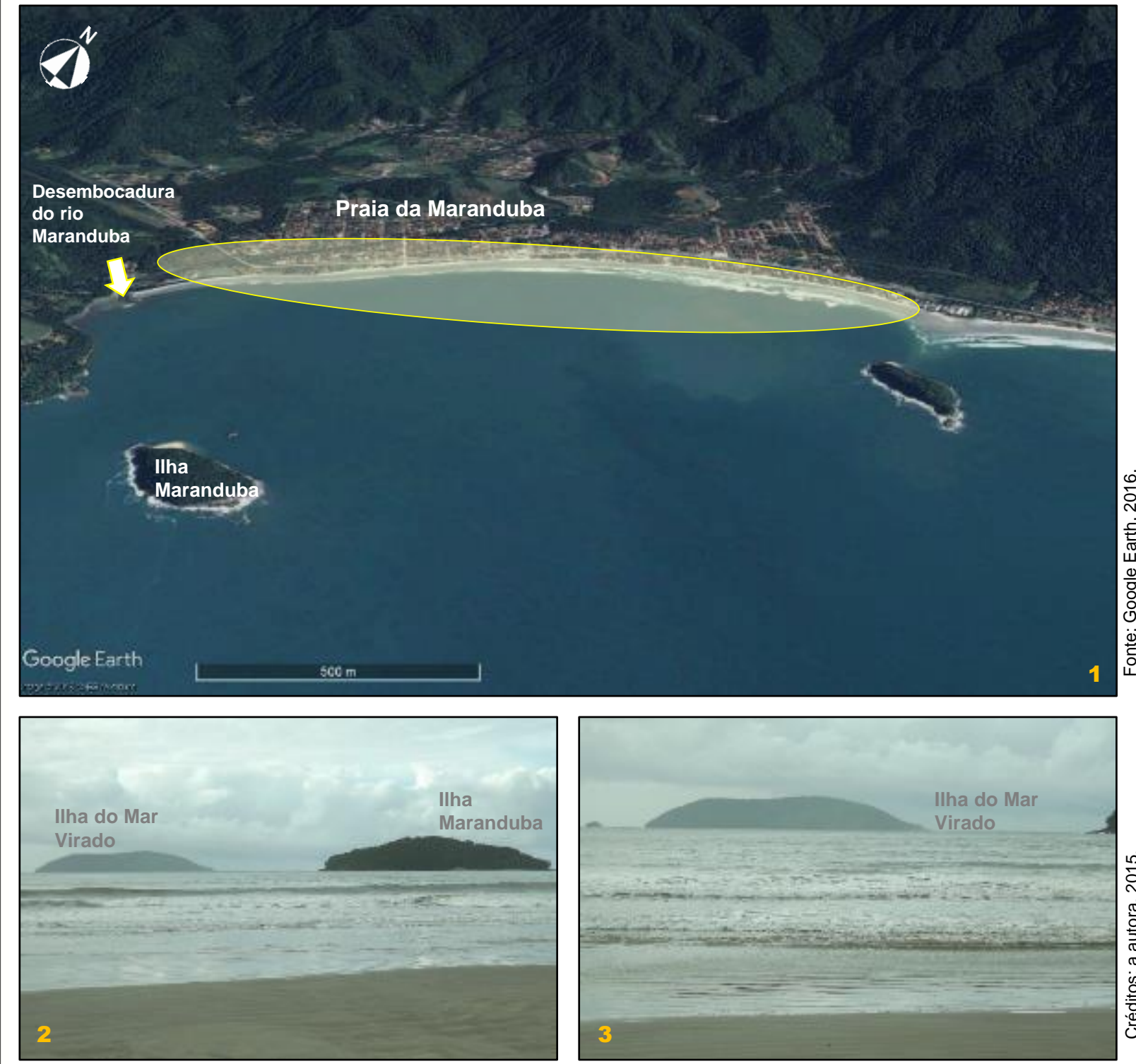

A praia da Maranbuba está localizada na enseada do Mar Virado, distante, aproximadamente, 22 quilômetros do núcleo urbano de Ubatuba e tem uma extensão de cerca de dois quilômetros, fazendo divisa a leste com a praia do Sapê e a oeste com o rio Maranduba e ele com o morro da Caçandoca (Imagem 1). Por fazer parte do mesmo segmento praial que a do Sapê e da Lagoinha, a praia da Maranduba possui características praticamente idênticas, sendo também uma praia de águas calmas, com ondas pequenas em condições meteorológicas normais, conforme se observa nas imagens 2 e 3, em registro realizado no outono de 2015 (fase da lua - quarto minguante). A declividade da plataforma continental é suave e a profundidade na enseada chega nos 10 metros já na "boca" (média da baixa mar de sizígia) (CARTA NÁUTICA 1635). A presença da ilha Maranbuda dentro da enseada (distante pouco mais de um quilômetro) acaba servindo como uma barreira natural e pode amenizar as ondas que chegam à praia. Possui uma grande área plana em direção as escarpas da serra do mar que podem alcançar pouco mais de dois quilômetros, interceptada de norte a sul pelo rio Maranduba. Caso os desembarques realmente acontecessem nesta praia, as mesmas condições atribuídas a desembarques na praia da Lagoinha valem para a praia da Maranduba. Apenas um acordo com o(s) dono(s) da terras da enseada sendo firmado seria possível o desembarque, o que, ao meu ver, torna o desembarque quase inviável. Mas no caso desses desembarques realmente terem acontecido, não faltavam locais para instalação das estruturas de recepção e nem acesso a água potável, situações fulcrais para o sucesso na recuperação dos cativos que chegavam debilitados depois da longa travessia.

Dissertação de Mestrado

A Diáspora Africana no litoral Norte paulista: desafios e possibilidades de uma abordagem arqueológica. 


\section{PRANCHA 19. Praia da Caçandoca}
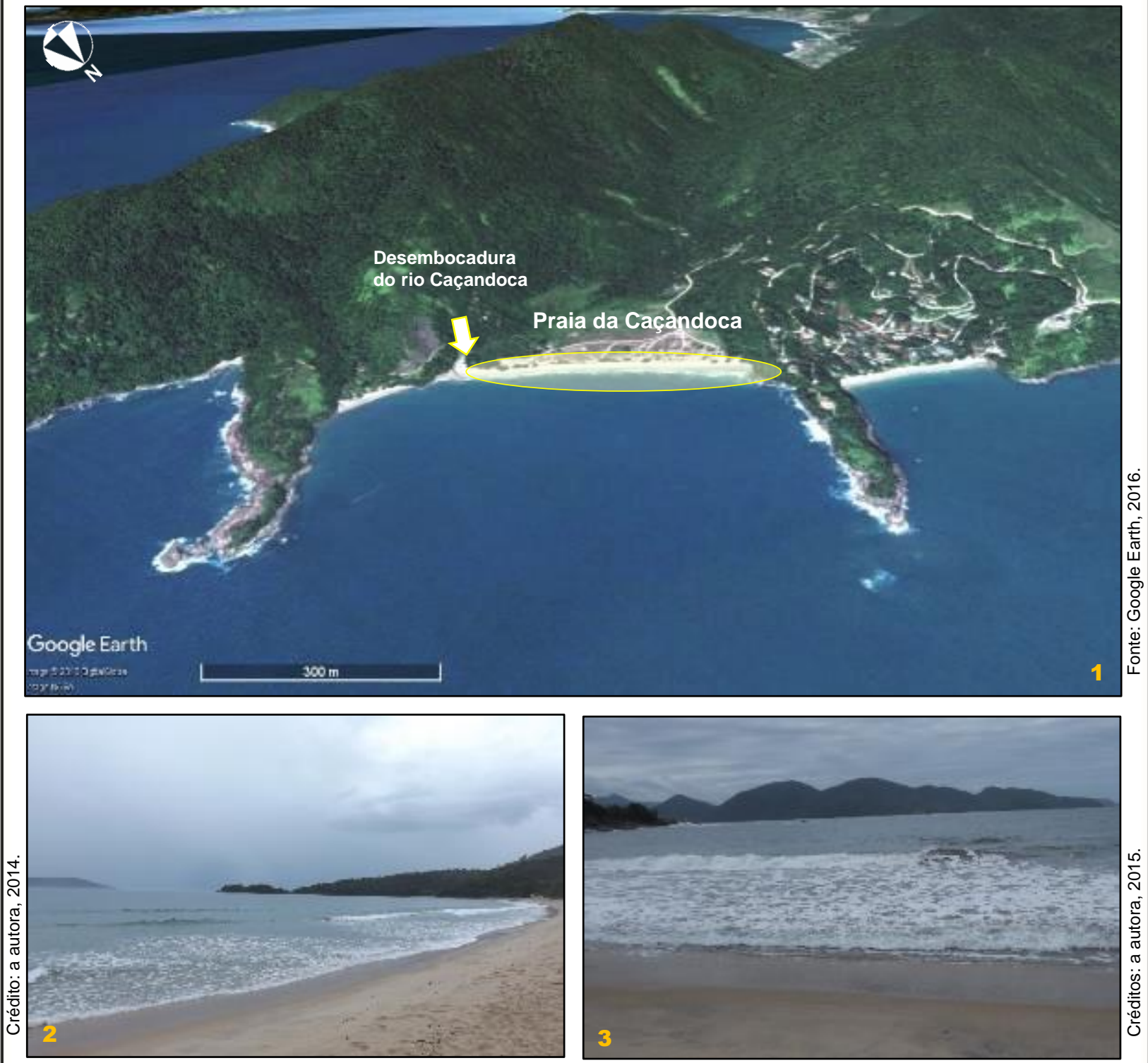

Localizada na enseada do Mar Virado, a praia da Caçandoca está localizada a mais de 25 quilômetros distante do núcleo urbano de Ubatuba e possui, aproximadamente, 800 metros de extensão (imagem 1). Apesar de estar na mesma enseada que as praias da Lagoinha e da Maranduba, sua orientação a nordeste não a expõe às mesmas condições oceanográficas. Com uma plataforma continental com declividade mais abrupta, profundidades maiores podem ser alcançadas logo após a zona de surfe e o fato de apresentar pequenas ondas em condições meteorológicas normais, não evita a influência de correntes costeiras, além de que as ondas podem se avolumar sem grandes alterações climáticas. A imagem 2 foi obtida na primavera de 2014 (fase da lua - lua nova) e a imagem 3 no outono de 2015 (fase da lua - quarto minguante) e, apesar de ângulos diferentes, a imagem 3 apresenta um mar com ondas mais significantes (CARTA NÁUTICA 1635). Apesar de uma área plana não tão grande, não faltavam locais para a instalação de estruturas de recepção. No entanto, é preciso considerar a existência nesta área, no século XIX, da Fazenda Caçandoca. Nesse sentido, o(os) proprietário(s) poderiam estar ou não estar envolvidos com o carregamento de africanos, ou poderiam somente ter arrendado o local para os desembarques. A presença de fontes de água potável na área era extremamente importante, visto a necessidade de fornecer água fresca aos africanos recém desembarcados. Além disso, existe a proteção dos dois "espigões naturais" que envolvem a praia e a zona onde as embarcações poderiam ficar, enquanto barcos menores realizavam o desembarque. É importante lembrar, que da mesma forma que as praias da Lagoinha e da Maranduba, a praia da Caçandoca por si só não poderia ser considerada um ponto de desembarque. Talvez, com o único diferencial que por ser uma fazenda ativa na época dos desembarques, se justificasse a presença de embarcações em frente a praia para o fornecimento de suprimentos, visto maior facilidade no transporte de mercadorias por água do que por terra.

Dissertação de Mestrado

A Diáspora Africana no litoral Norte paulista: desafios e possibilidades de uma abordagem arqueológica. 


\section{PRANCHA 20. Locais utilizados como pontos de desembarques - Caraguatatuba}

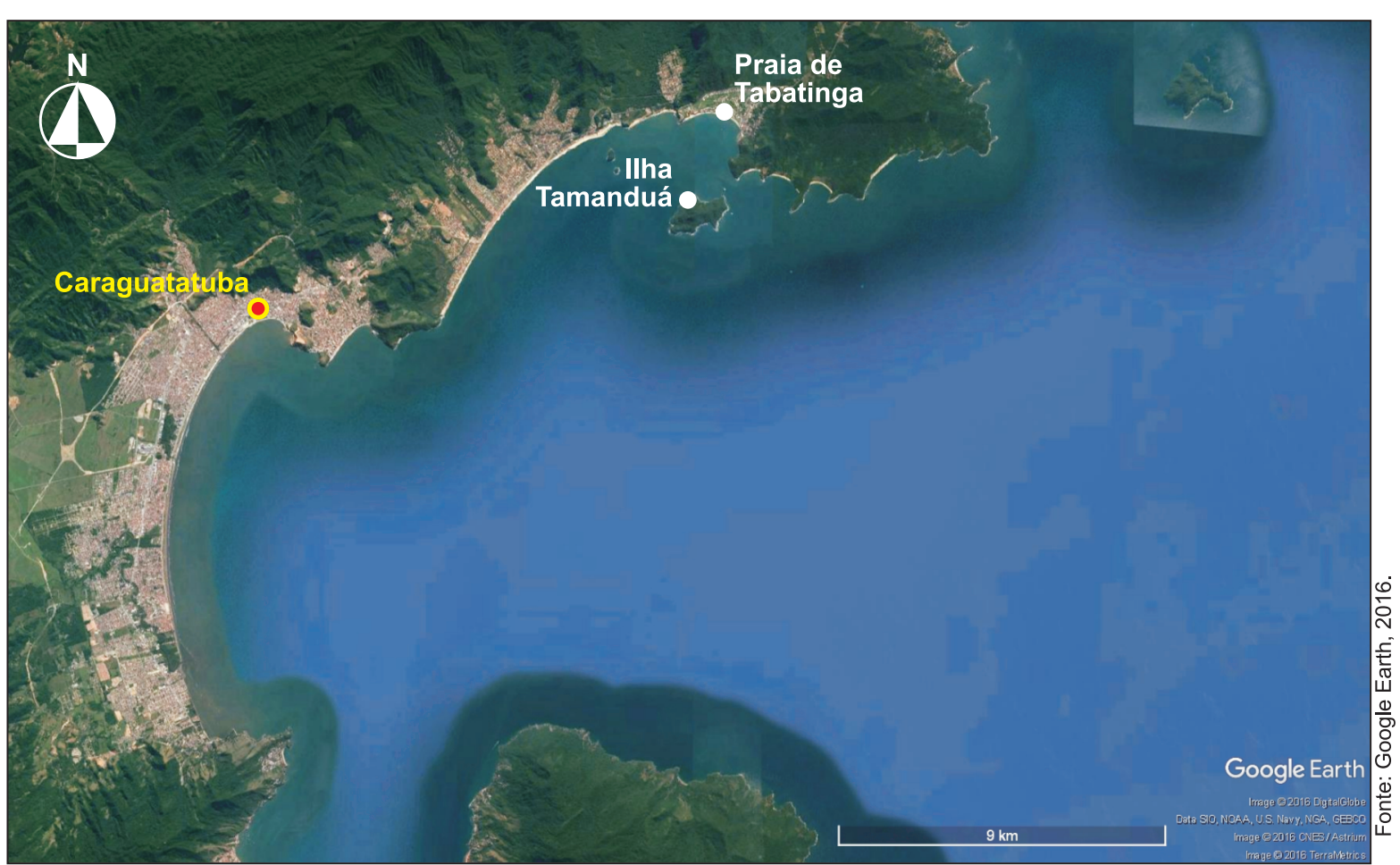

A imagem acima apresenta a espacialização dos locais indicados como pontos de desembarques clandestinos no município de Caraguatatuba.

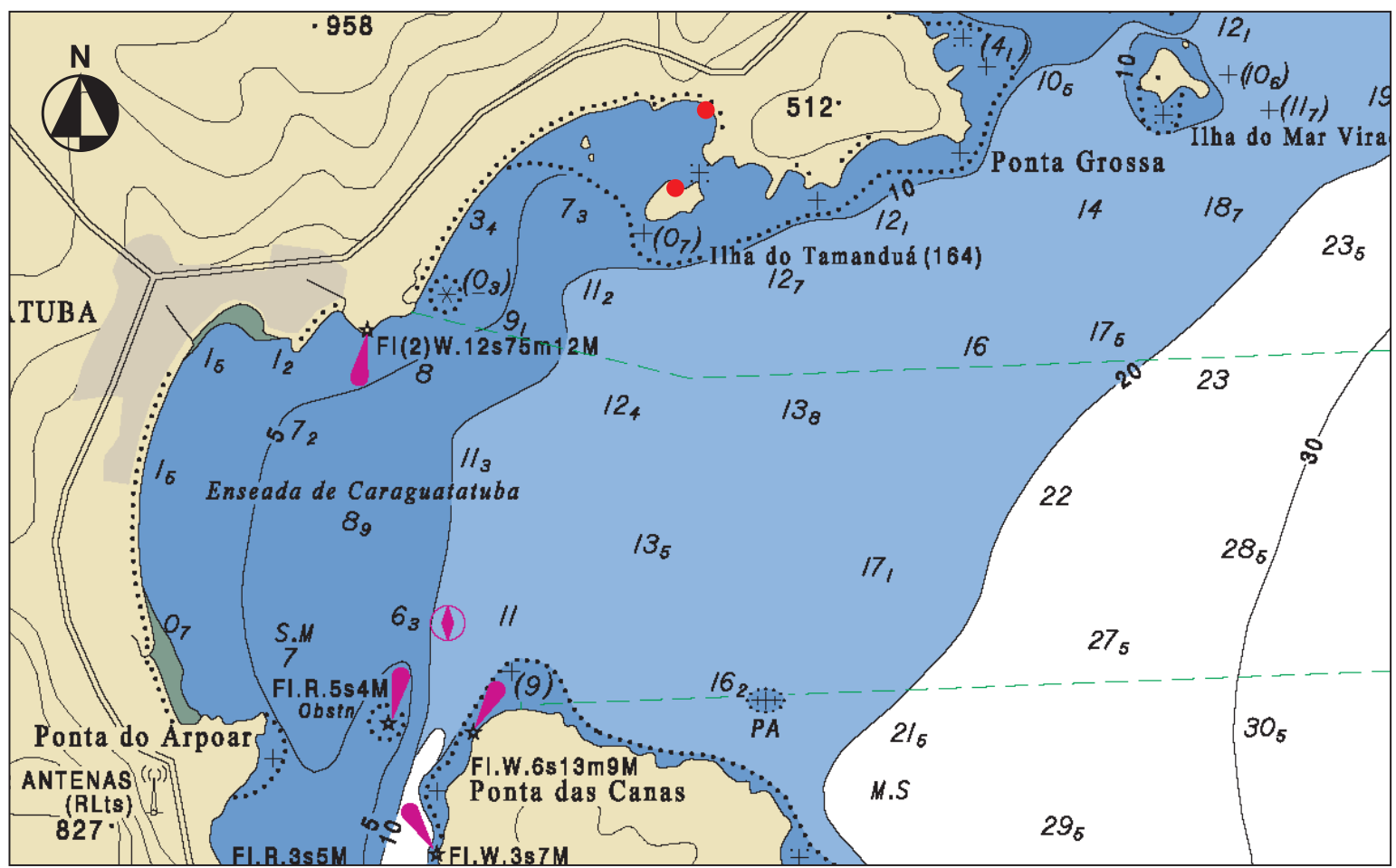

Acima um recorte da Carta Náutica (CARTA NÁUTICA 2310023100 - INT.2124) com todos os locais indicados como pontos de desembarque no município de Caraguatatuba. A inserção desse recorte se dá afim de mostrar a perspectiva de quem chega pelo oceano, com os obstáculos naturais, marcadores na paisagem, variações de profundidades, correntes, ventos, etc. Com um litoral praticamente sem reentrâncias, sendo a porção Sul protegida pela porção Norte da ilha de São Sebastião, Caraguatatuba não apresentou muitos locais associados aos desembarques, sendo que tal situação, a meu ver, se justifica não só pela falta de locais que abrigariam os desembarques, mas, mais ainda, pela grande disponibilidade de locais propícios nas imediações.

\section{Dissertação de Mestrado}

A Diáspora Africana no litoral Norte paulista: desafios e possibilidades de uma abordagem arqueológica. Aluna: Luciana Bozzo Alves

Orientador: Prof. Dr. Pedro Paulo de Abreu Funari 


\section{PRANCHA 21. Praia de Tabatinga}
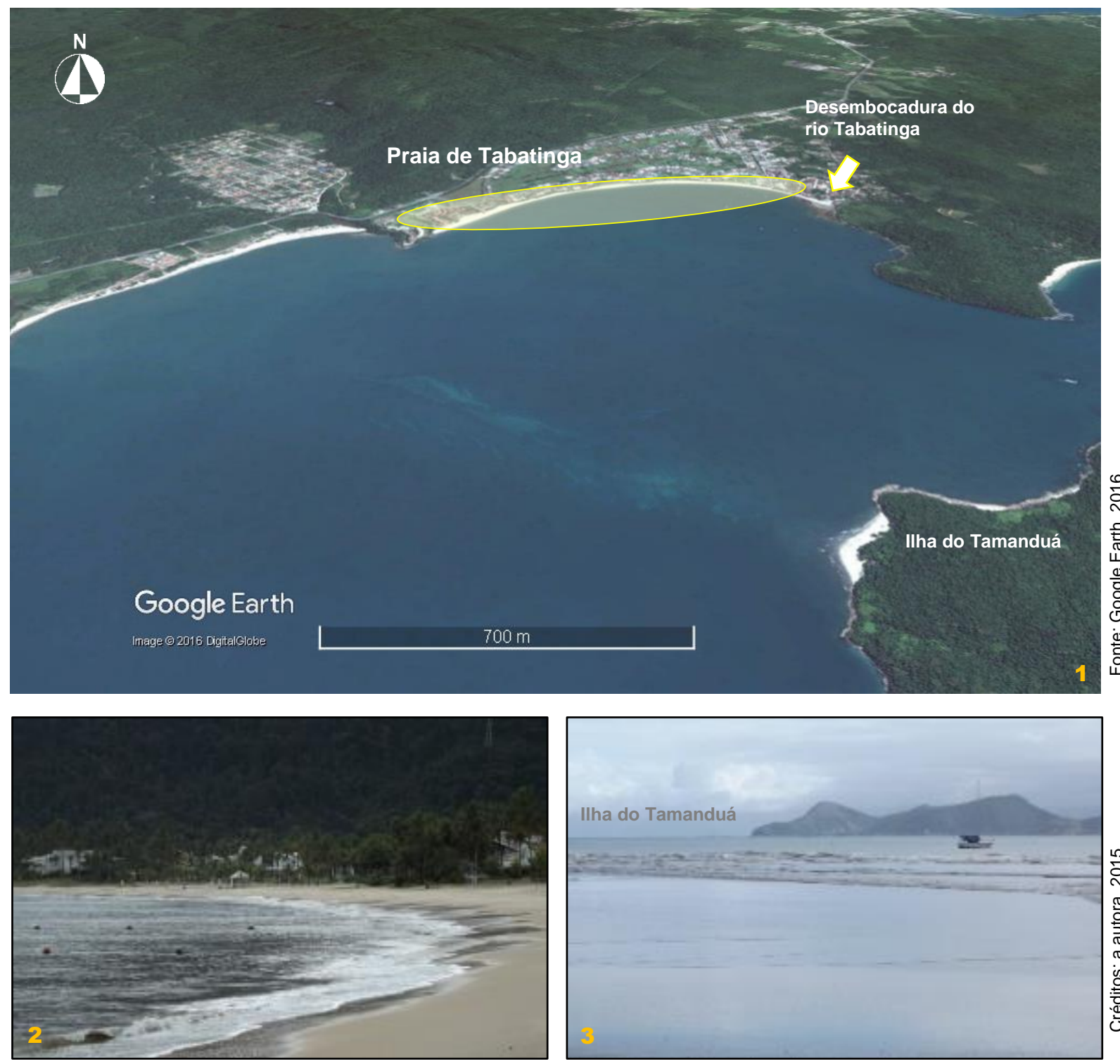

A praia de Tabatinga está localizada a aproximadamente 20 quilômetros a nordeste do núcleo urbano de Caraguatatuba e possui menos de dois quilômetros de extensão (Imagem 1). É uma praia de águas calmas, com ondas pequenas em condições meteorológicas normais, conforme se observa nas imagens 2 e 3, em registro feito no outono de 2015 (fase da lua - quarto minguante). A declividade da plataforma continental é suave e a profundidade terá poucas variações até a ilha do Tamanduá, por exemplo, não ultrapassando os três metros (média da baixa mar de sizígia) (CARTA NÁUTICA 1641). As pequenas ondas que chegam vão arrebentar somente próximas a faixa de areia. A presença da llha do Tamanduá (também indicada como ponto de desembarque) que dista pouco mais de dois quilômetros da praia, acaba criando uma barreia natural para as correntes litorâneas que chegam a areia. Após a zona de surfe, é possível atracar as embarcações e, caso isso tenha ocorrido no século XIX, a partir dali já era possível que as pequenas embarcações que davam apoio aos negreiros pudessem fazer os desembarques. De todas as praias de Caraguatatuba, a meu ver, a única onde esses desembarques poderiam ser realizados é justamente a de Tabatinga, pois encontra-se mais protegida. Por terra, por causa do relevo mais escarpado em seu entorno, caracterizando um "anfiteatro" e atribuindo a esse ponto específico da costa caraguatatubense um abrigo natural, protegido de correntes e ventanias continentais. A planície existente após a faixa de areia permitira a instalação de estruturas necessárias a recepção dos africanos recém desembarcados; a presença do rio Tabatinga no canto esquerdo da praia permitiria o acesso à água potável rapidamente. A "invisibilidade" desse ponto, só se caracteriza pela presença da ilha do Tamanduá a frente e pela paisagem de seu entorno.

Dissertação de Mestrado

A Diáspora Africana no litoral Norte paulista: desafios e possibilidades de uma abordagem arqueológica. 
PRANCHA 22. Locais utilizados como pontos de desembarques - São Sebastião

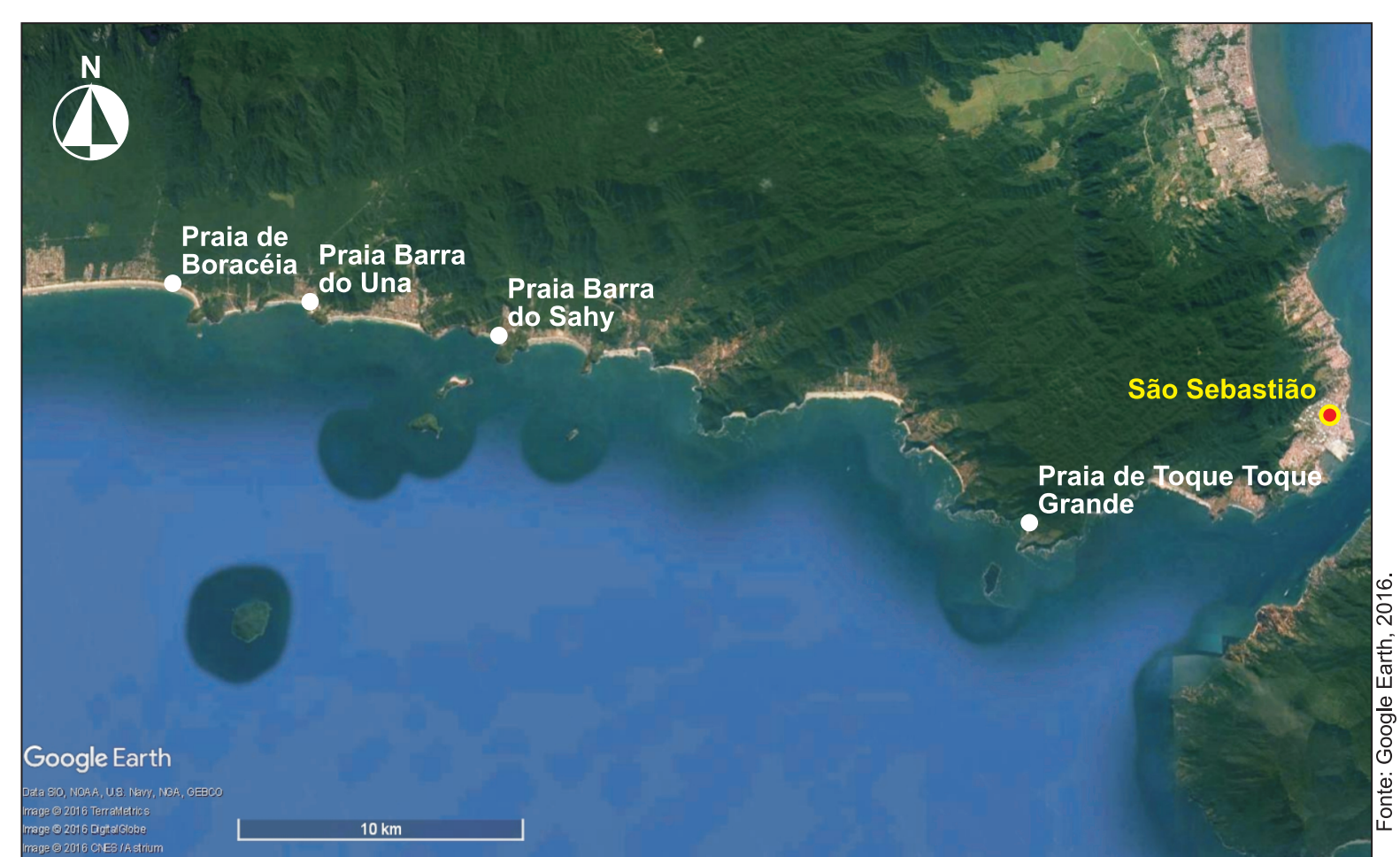

A imagem acima apresenta o município de São Sebastião com a espacialização de todos os locais indicados como pontos de desembarques clandestinos.

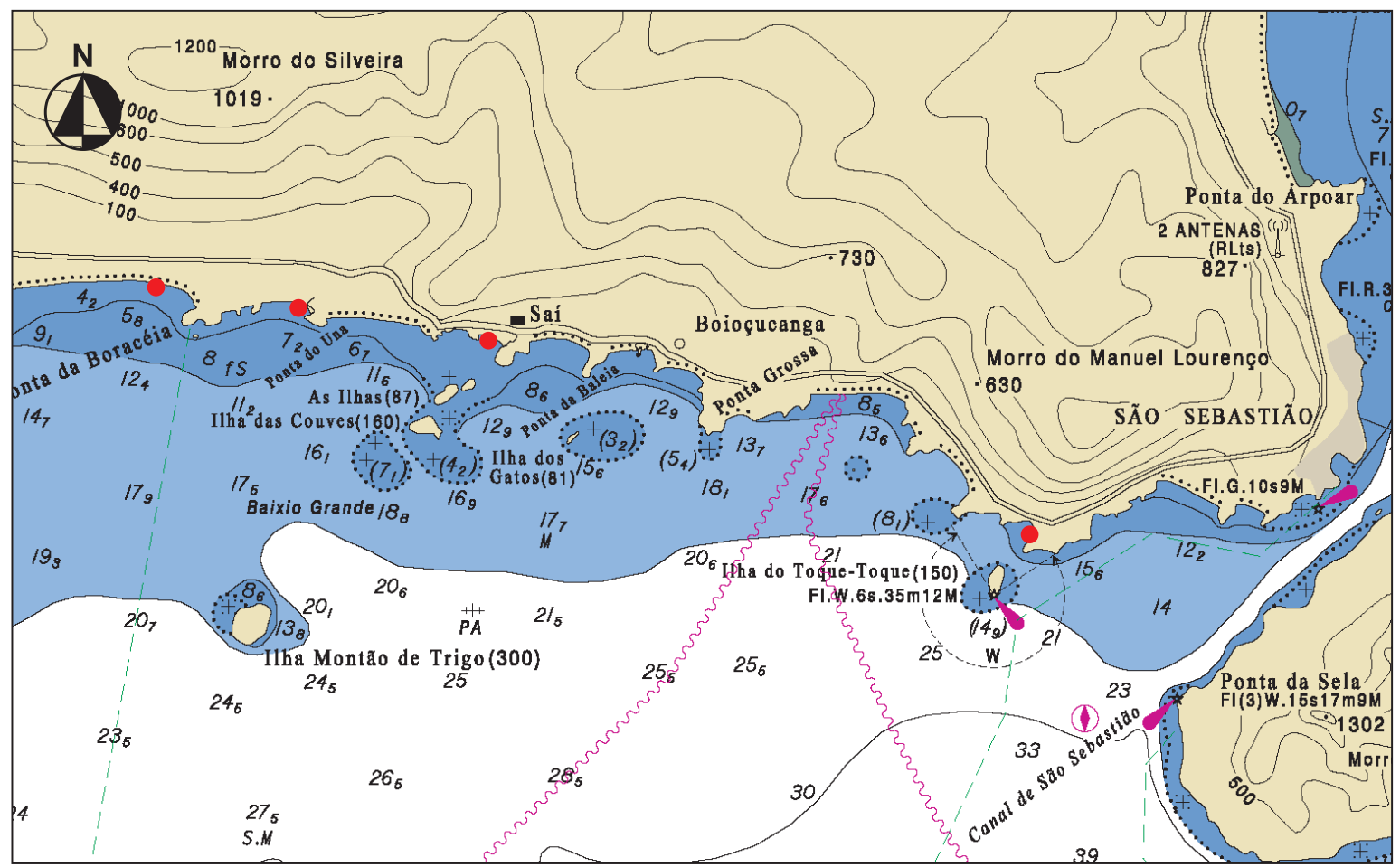

Acima se observa um recorte da Carta Náutica (CARTA NÁUTICA 2310023100 - INT.2124) com todos os locais indicados como pontos de desembarque no município de São Sebastião. A inserção desse recorte se dá no sentido de colocar um olhar de quem chega pelo oceano, com os obstáculos naturais, marcadores na paisagem, variações de profundidades, correntes, ventos, etc. Para São Sebastião, as suaves reentrâncias de seu litoral se dão a partir do núcleo urbano no sentido oeste.

De uma maneira geral, as aproximações das embarcações poderiam ser feitas, devido, principalmente, a um "certo isolamento", o que atribuiria um caráter de segurança. No detalhamento das praias esse fato será retomado.

Dissertação de Mestrado

\begin{tabular}{|l|l|}
\hline \multicolumn{2}{|c|}{ Dissertação de Mestrado } \\
\hline \multicolumn{2}{|c|}{$\begin{array}{c}\text { A Diáspora Africana no litoral Norte paulista: } \\
\text { desafios e possibilidades de uma abordagem arqueológica. }\end{array}$} \\
\hline Aluna: Luciana Bozzo Alves \\
\hline Orientador: Prof. Dr. Pedro Paulo de Abreu Funari & dez/16 \\
\hline Museu de Arqueologia e Etnologia / USP &
\end{tabular}




\section{PRANCHA 23. Praia de Toque Toque Grande}
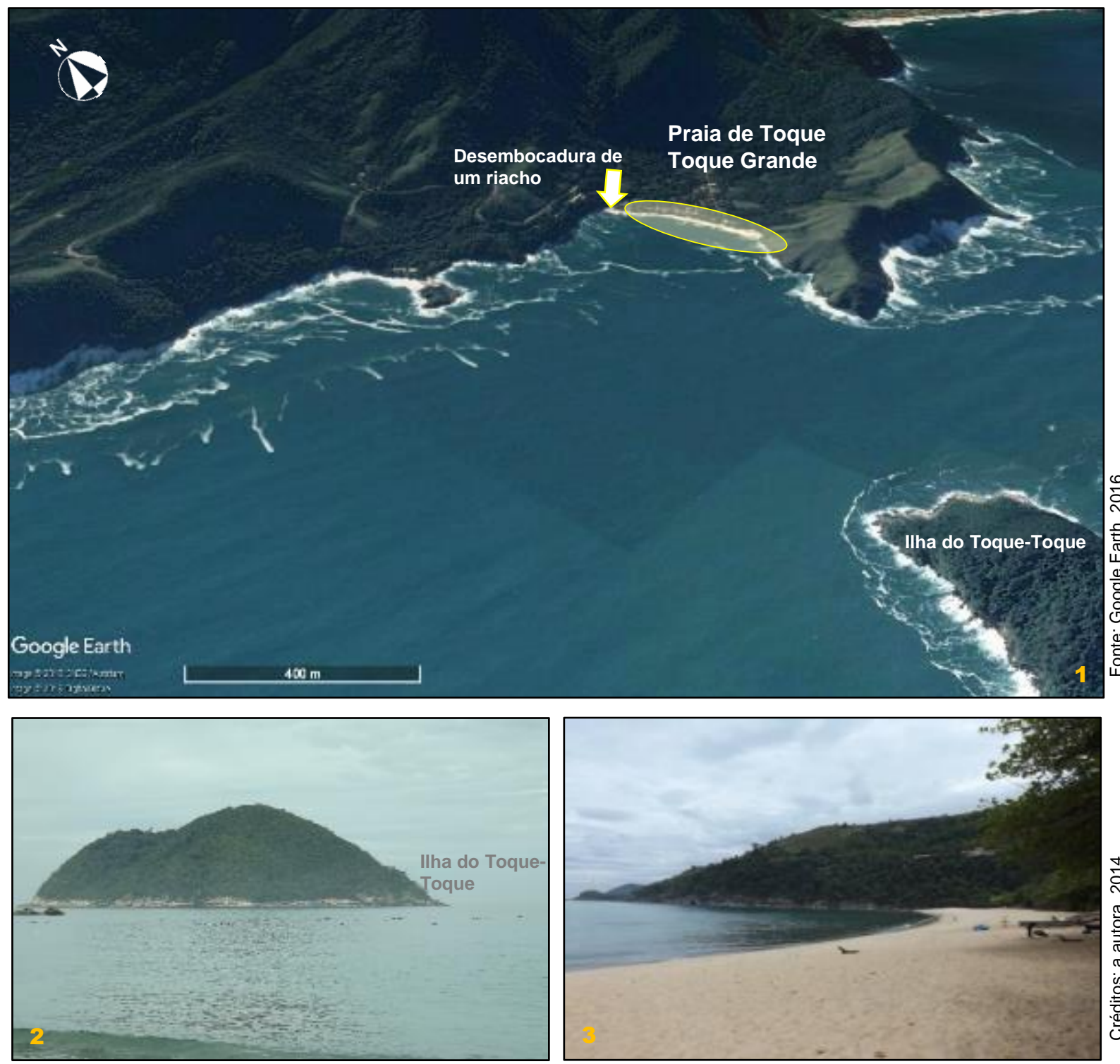

Distante, aproximadamente, 15 quilômetros do núcleo urbano de São Sebastião, a praia de Toque Toque Grande possui pouco mais de 500 metros de extensão (Imagem 1). Encontra-se encaixada em meio a elevações características da serra do Mar e que atribuem a essa porção do litoral um aspecto afogado. No dia do registro fotográfico, na primavera de 2014 (fase da lua - lua nova) praticamente não existiam ondas (Imagens 2 e 3), mas, não é sempre assim. Apesar disso, mesmo com ondas arrebentando na praia de maneira mais consistente, devido principalmente a uma plataforma continental com sensível inclinação, após a zona de surfe é possível fundear embarcações (CARTA NÁUTICA 1644). Após a faixa de areia, é possível identificar pequena área com suave declividade que possibilitaria a instalação de estruturas para a recepção dos africanos, além da disponibilidade de água doce no local, conforme se observa em um pequeno riacho que deságua no canto esquerdo da praia. A paisagem do entorno possibilitaria a aproximação de embarcações sem chamar atenção e, assim, poderia permanecer fundeada após a zona de surfe. Se a embarcação viesse descendo pela corrente do Brasil, ao se aproximar da costa sudeste, poderia fazer a sua aproximação apenas perto da ilha de São Sebastião, o que faria com que não fosse vista por possíveis "vigias" no porto de São Sebastião. Nesse sentido, após ultrapassar a ilha, a embarcação poderia rumar para a praia de Toque Toque Grande sem ter sido vista. Com a aproximação, ainda contaria com a barreira natural gerada pela presença da ilha de Toque-Toque e poderia fundear $e$ realizar o desembarque dos africanos com apoio de embarcações menores para levá-los até a praia.

Dissertação de Mestrado

A Diáspora Africana no litoral Norte paulista: desafios e possibilidades de uma abordagem arqueológica. 


\section{PRANCHA 24. Praia da Barra do Sahy}
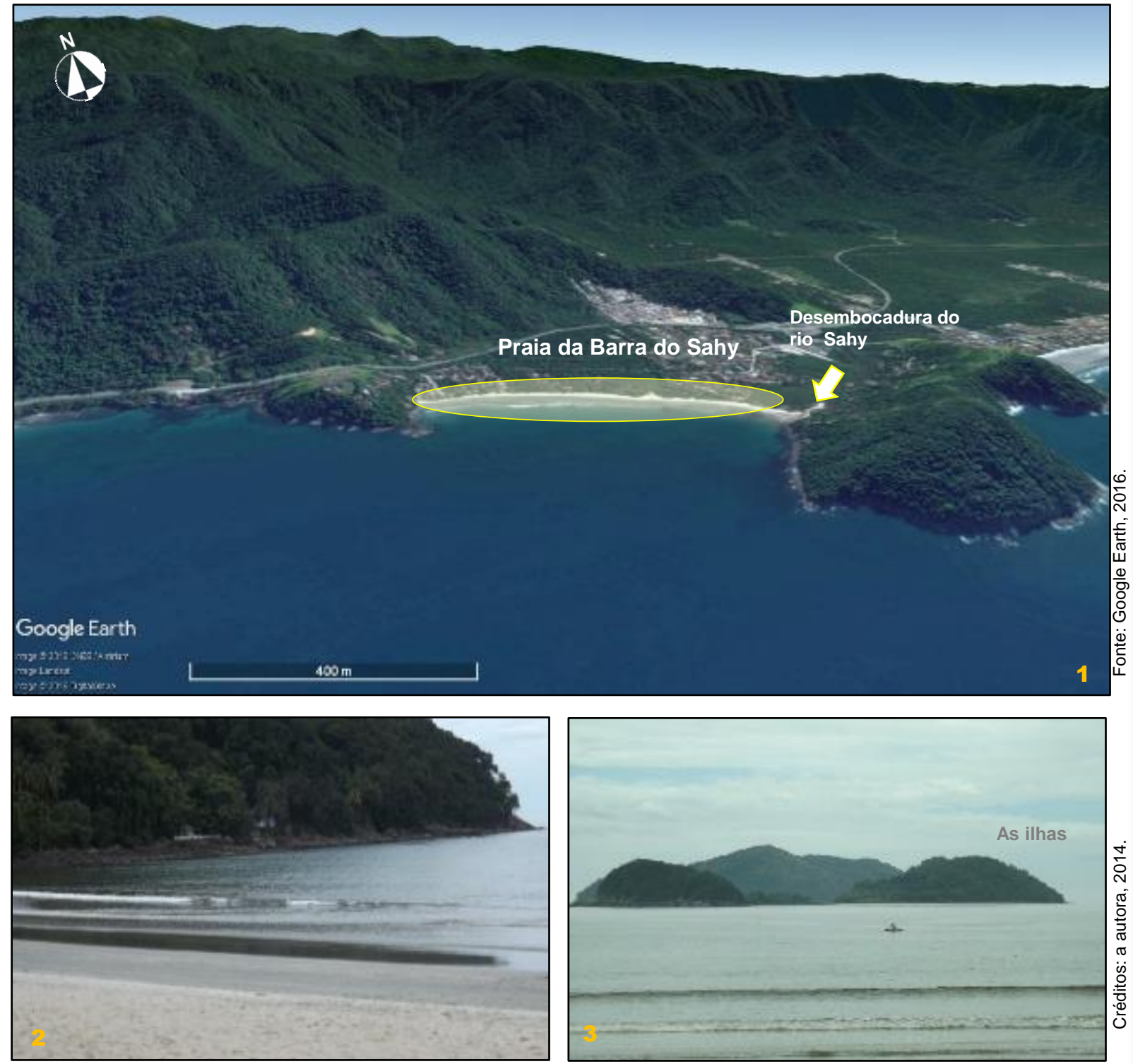

A praia da Barra do Sahy está, aproximadamente, 50 quilômetros distante do centro de São Sebastião e possui quase um quilômetro de extensão (Imagem 1). Com uma plataforma continental com inclinação mais acentuada, a profundidade, após a zona de surfe, pode chegar a oito metros (média da baixa mar de sizígia) (CARTA NÁUTICA 2310023100 (INT.2124)). No dia do registro fotográfico, na primavera de 2014 (fase da lua - lua nova), praticamente não existiam ondas (Imagens 2 e 3). Apesar de ser considerada uma praia de mar aberto, a presença de ilhas a uma distância inicial de pouco menos de dois quilômetros atribui um caráter abrigado à praia da Barra do Sahy, fazendo com que haja a formação de pequenas ondas. Após a faixa de areia, existe uma pequena área plana que poderia ter sido utilizada para a instalação das estruturas de recepção. A presença do rio Sahy no canto esquerdo da praia também é um fator positivo, pois assim que desembarcavam os africanos precisavam ter acesso à água potável. De acordo com Boccia e Malerbi 1977, a área abrangida desde o Rio Una até São Sebastião era de alta incidência de relatos de desembarques clandestinos, sendo que a praia da Barra do Sahy está inserida nesse intervalo. Com características favoráveis, essa praia possui áreas propícias a instalação de estruturas para receber os africanos, água potável, condições oceanográficas adequadas para a aproximação de embarcações e possibilidade do apoio de pequenas embarcações no desembarque dos africanos. Caso desejassem, as embarcações de apoio poderiam adentrar ao continente por meio do rio Sahy e, com isso, os desembarques aconteceriam com mais segurança e talvez mais próximos aos locais que seriam utilizados para acomodar os africanos.

Dissertação de Mestrado

A Diáspora Africana no litoral Norte paulista: desafios e possibilidades de uma abordagem arqueológica. 


\section{PRANCHA 25. Praia da Barra do Una}
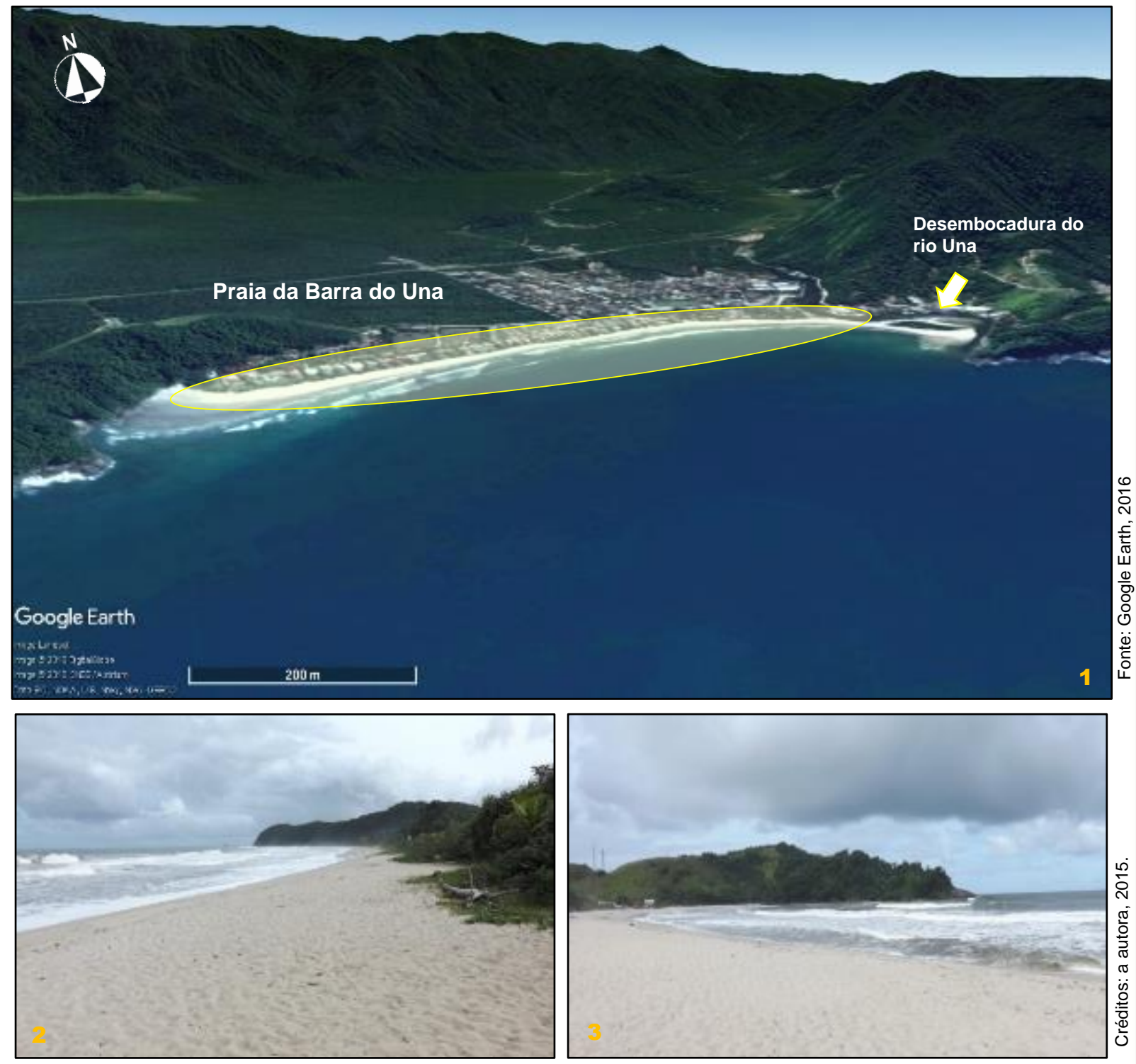

Localizada a mais de 55 quilômetros do centro de São Sebastião, a praia da Barra do Una é uma das últimas praias do litoral "sul" de São Sebastião (Imagem 1). Com uma plataforma continental com inclinação mais suavizada, a profundidade após a zona de surfe pode chegar a quatro metros (média da baixa mar de sizígia) (CARTA NÁUTICA 2310023100 (INT.2124)). O registro fotográfico (Imagens 2 e 3) foi obtido no outono de 2015 (fase da lua - quarto minguante). A presença do rio Una no canto esquerdo da praia também é um fator positivo, pois assim que desembarcavam os africanos precisavam ter acesso à água potável. Como visto para a praia da Barra do Sahy, segundo Boccia e Malerbi 1977, a área abrangida desde o Rio Una até São Sebastião era de alta incidência de relatos de desembarques clandestinos. Acredito que o rio Una fosse usado como referência, mas a praia homônima também entraria no grupo dos locais potenciais para desembarque de escravos. No entanto, a praia da Barra do Una sofre influência de uma forte "correnteza de costeira", o que poderia dificultar o acesso à costa por barcos menores que estivessem auxiliando os negreiros. Além disso, a planície que se inicia após a faixa de areia é bastante extensa e se estende até o município de Bertioga. O que não daria proteção visual por terra, de possíveis estruturas de recepção levantadas na planície próxima a praia. No entanto, talvez a proximidade com os mercados consumidores no Vale do Paraíba, justificassem os risco de um desembarque nestas praias. Nesse sentido, do ponto de vista oceanográfico, os desembarques seriam mais arriscados, não para a aproximação das embarcações negreiras, mas para as embarcações menores que trariam os africanos para terra firme. Se resolvessem seguir remando pelo rio Una, também seria difícil, devido ao volume hídrico que o rio possui até hoje. Pela paisagem do entorno, seria arriscado montar uma estrutura em uma área tão aberta, a não ser que se caminhasse até a base das escarpas e lá fossem construídas.

Dissertação de Mestrado

A Diáspora Africana no litoral Norte paulista: desafios e possibilidades de uma abordagem arqueológica. 


\section{PRANCHA 26. Praia de Boracéia}
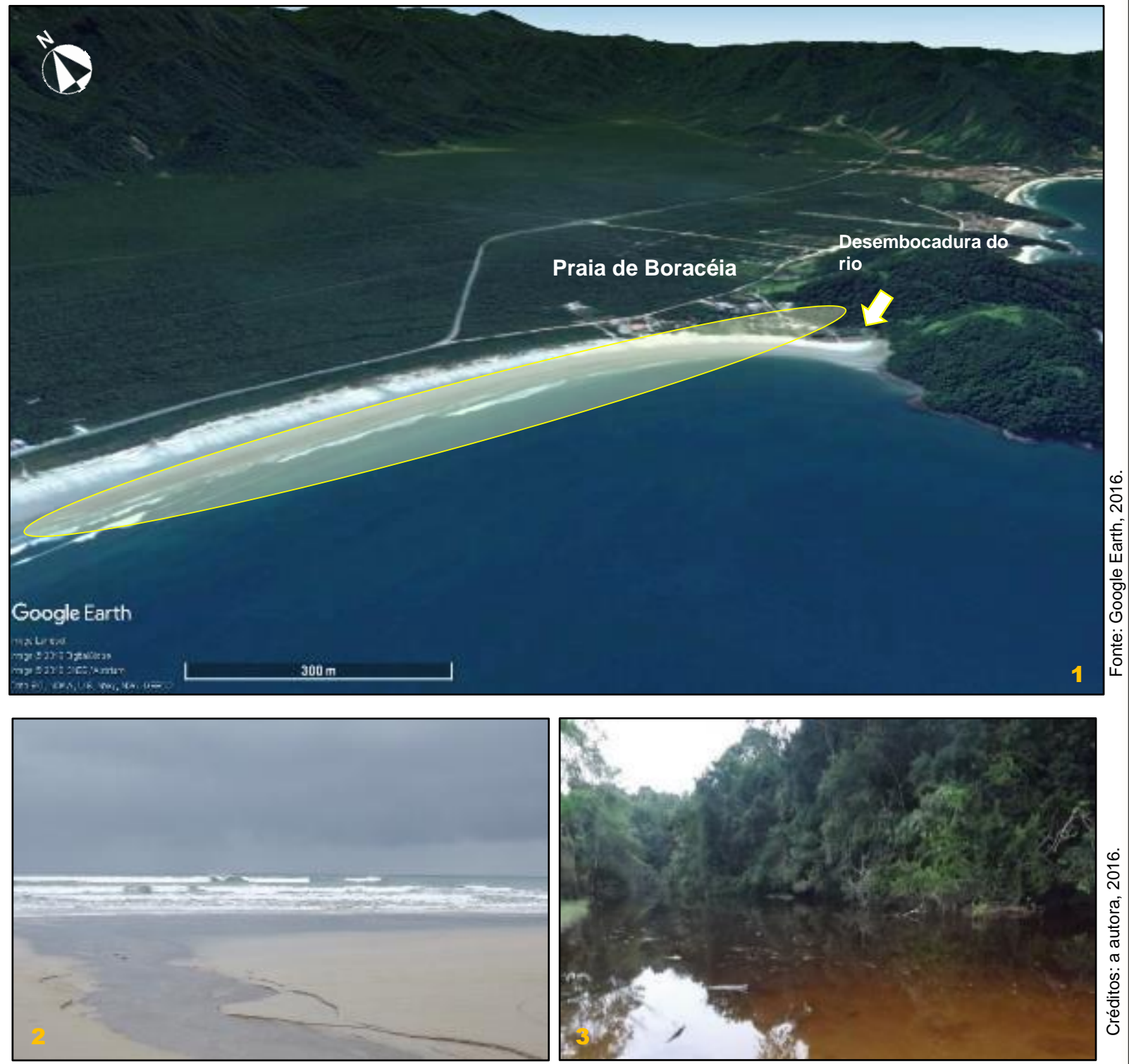

Mais da metade da praia de Boracéia faz parte do município de São Sebastião. Com distância até o centro de São Sebastião estimada em 60 quilômetros, essa faixa tem quase cinco quilômetros de extensão (Imagem 1), sendo que os outros três quilômetros de praia já fazem parte do município de Bertioga. A imagem 2 mostra o discreto rio Bertioga marcando as areias da praia, sendo ele o marcador natural da divisa dos dois municípios. Ao fundo, observa-se as ondas constantes após uma longa faixa de areia. Essas imagens foram obtidas no inverno de 2016 (fase da lua - lua cheia), e as condições meteorológicas estavam instáveis. Após a faixa de areia existe uma grande planície e, nesse sentido, entendo que os mesmos problemas apontados para a praia da Barra do Una aconteceriam aqui. A extensão da planície dificultaria a instalação de estruturas de recepção sem chamar a atenção. No canto esquerdo da praia foi localizado um rio (Imagem 3) que desemboca no mar junto ao morro que limita a praia a sudeste. Caso realmente acontecessem desembarques nesta praia, uma das opções seria as embarcações de apoio ao negreiros entrarem remando pelo rio para efetuar o desembarque de maneira mais segura e mais distante da praia. Apesar da proximidade com o mercado consumidor, outros fatores devem ter sido considerados na hora de optar por esse ponto. É um conjunto de variáveis que vai influenciar o sucesso ou insucesso dos desembarques e, a meu ver, a praia de Boracéia não contempla esse conjunto.

Dissertação de Mestrado

A Diáspora Africana no litoral Norte paulista: desafios e possibilidades de uma abordagem arqueológica. 
PRANCHA 27. Locais utilizados como pontos de desembarques - Illhabela

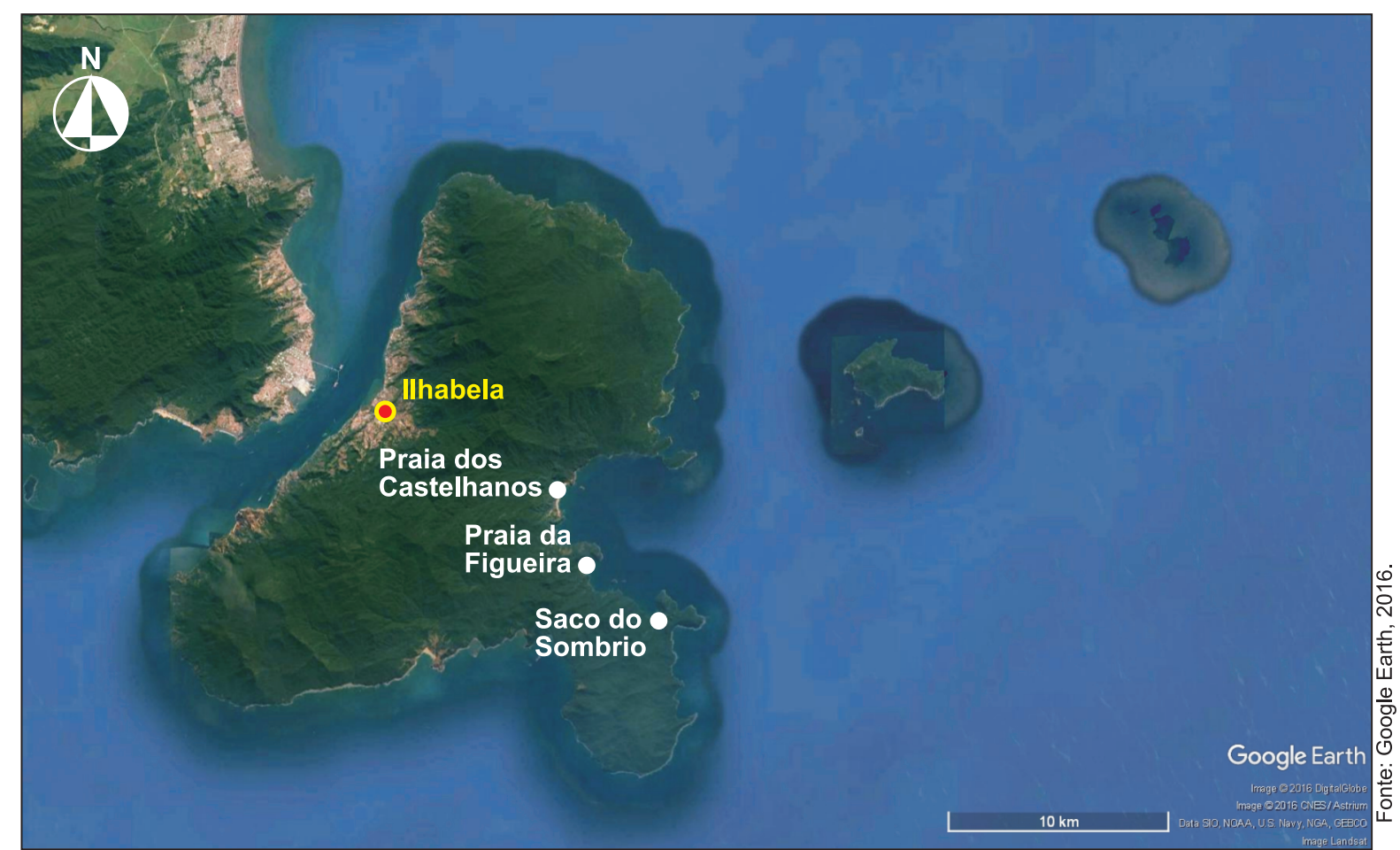

A imagem acima apresenta a espacialização de todos os locais indicados como pontos de desembarques clandestino no município de llhabela.

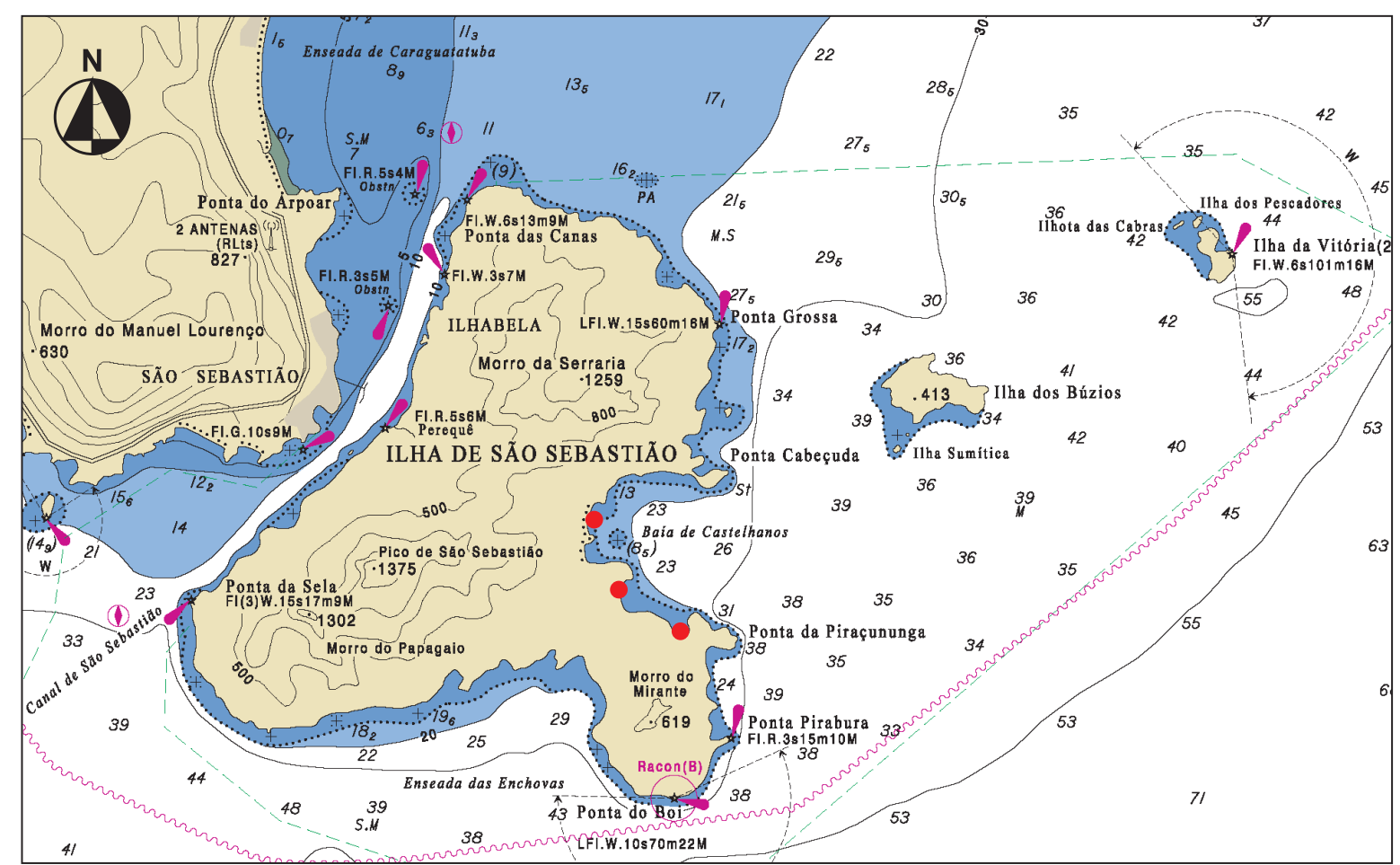

O recorte da Carta Náutica (CARTA NÁUTICA 2310023100 - INT.2124) apresentado acima expõe todos os locais indicados como pontos de desembarque no município de llhabela. A inserção desse recorte se dá a fim de indicar o olhar de quem chega pelo oceano, com os obstáculos naturais, marcadores na paisagem, variações de profundidades, correntes, ventos, etc. Para a ilha de São Sebastião, principal do município de Ilhabela, praticamente todos os locais possíveis de desembarques ilegais estão localizados na Baía de Castelhanos. Essa situação se dá, principalmente, pela invisibilidade atribuída a essa face da ilha em relação a face Oeste, que fica em frente a São Sebastião.

Dissertação de Mestrado

\begin{tabular}{|l|l|}
\hline \multicolumn{2}{|c|}{ Dissertação de Mestrado } \\
\hline $\begin{array}{c}\text { A Diáspora Africana no litoral Norte paulista: } \\
\text { desafios e possibilidades de uma abordagem arqueológica. }\end{array}$ \\
\hline Aluna: Luciana Bozzo Alves \\
\hline Orientador: Prof. Dr. Pedro Paulo de Abreu Funari \\
\hline Museu de Arqueologia e Etnologia / USP & dez/16 \\
\hline
\end{tabular}




\section{PRANCHA 28. Praia dos Castelhanos}
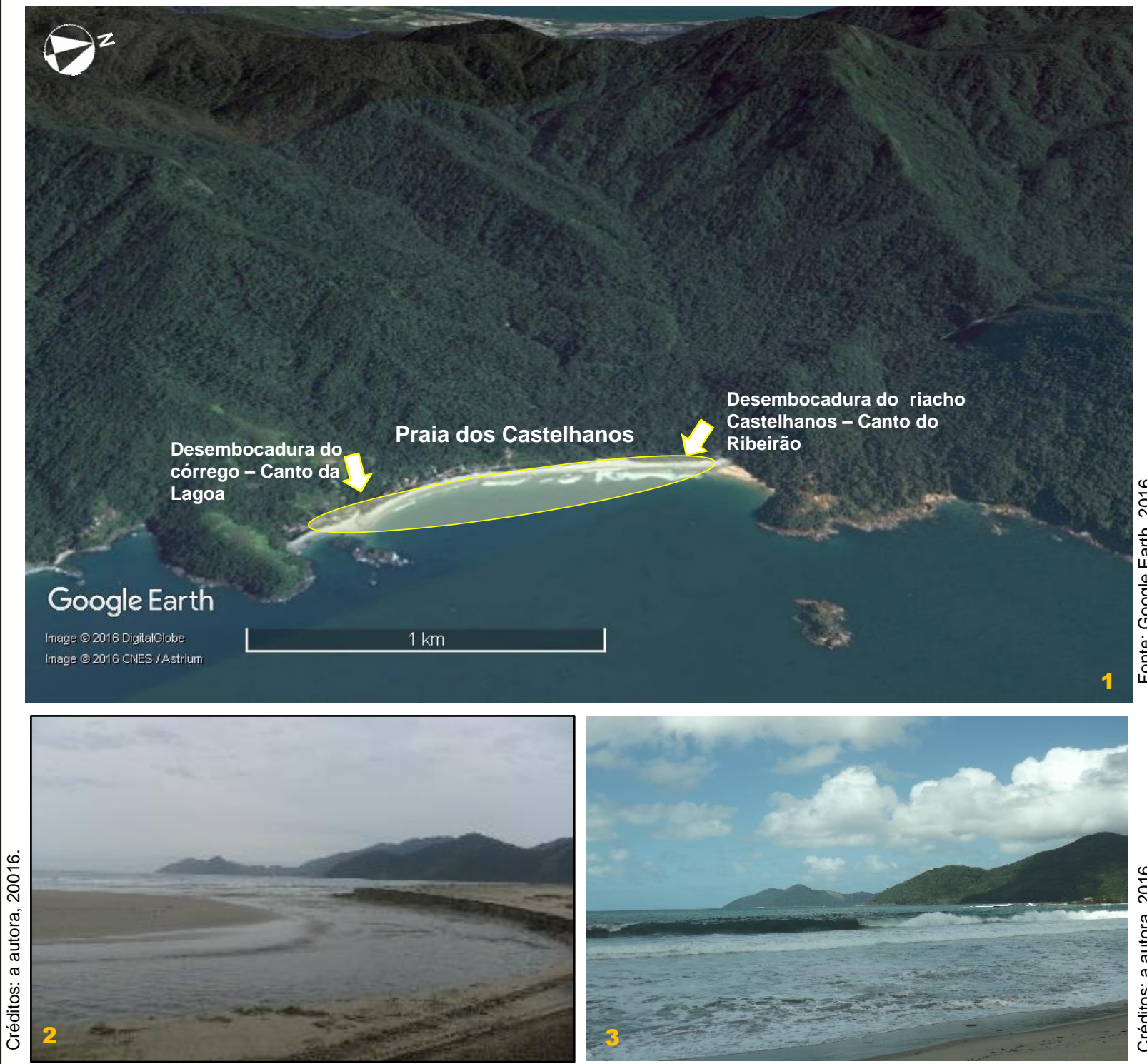

Localizada na baía de Castelhanos, na face leste da ilha de São Sebastião, principal ilha do município de Ilhabela, a praia dos Castelhanos tem aproximadamente um quilômetro e meio de extensão (Imagem 1). A profundidade na "boca" da baía pode chegar a 30 metros e a praia dos Castelhanos também possui uma declividade razoavelmente acentuada, sendo que a profundidade depois da zona de surfe pode chegar a oito metros (CARTA NÁUTICA 1645). A referência aos "portos de escravos da baía de Castelhanos" são recorrentes na bibliográfica específica (FRANÇA, 1954; MARCíLIO, 2006; NOFFS, 2008, entre outros) e deve-se ao fato de que, após o desembarque nesta face da ilha e após terem se restabelecido um pouco, os africanos poderiam dar entrada em São Sebastião em barcos menores como se fossem "escravos ladinos". Existem referência também a fazendas e engenhos nessa praia, que possui rios nas duas extremidades, sendo o riacho dos Castelhanos (Imagem 2, obtida no inverno de 2016 (fase da lua - lua cheia)) no canto do Ribeirão e um pequeno riacho próximo ao Canto da Lagoa. É uma "praia de onda" (Imagem 3, obtida no inverno de 2016, fase da lua - lua cheia), como dizem os moradores e, quando há vento de leste, as ondas alcançam um metro e meio, ficando praticamente inviável sair de barco. Apesar de estar em uma baía, a praia dos Castelhanos tem um mar muito agitado, sofrendo as interferências tanto do vento, quanto das alterações meteorológicas. A proteção que a própria baía impõe aos locais de desembarque já se caracteriza com um elemento facilitador, além de que, após a finalização dos desembarques, as embarcações negreiras podem entrar rapidamente nos portos para ajustes e, quem sabe, uma carga de produtos tropicais para levar à Europa. É na praia dos Castelhanos que após fortes chuvas na região, o nível do riacho que desemboca no canto da Lagoa transbordou e trouxe a tona uma embarcação que estava enterrada na areia e que pode ter sido utilizada no comércio de escravos negros.

Dissertação de Mestrado

A Diáspora Africana no litoral Norte paulista: desafios e possibilidades de uma abordagem arqueológica.

\begin{tabular}{l}
\hline Aluna: Luciana Bozzo Alves \\
\hline Orientador: Prof. Dr. Pedro Paulo de Abreu Funari \\
\hline Museu de Arqueologia e Etnologia / USP
\end{tabular}




\section{PRANCHA 29. Praia da Figueira}
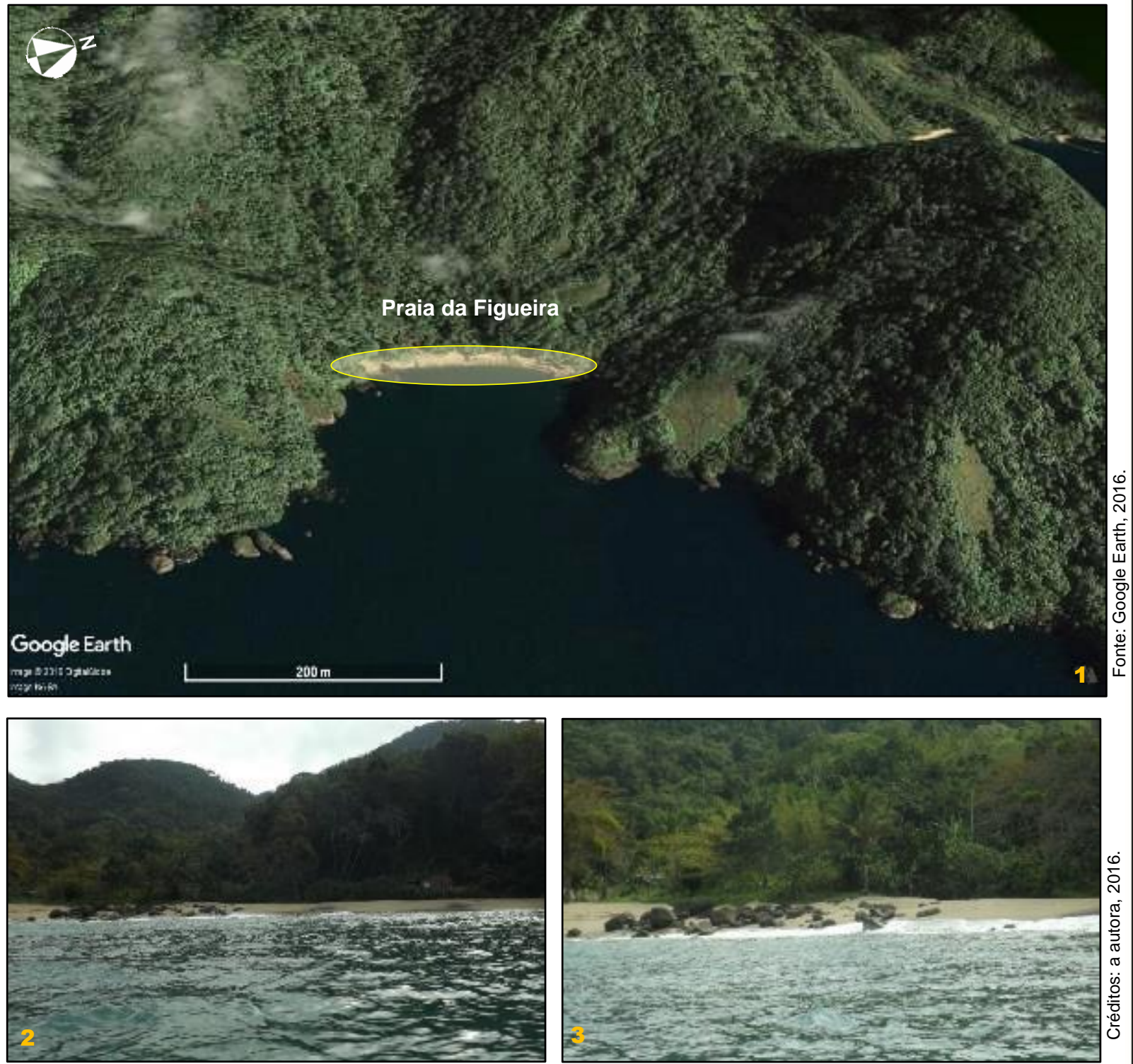

A Praia da Figueira também está localizada na baía de Castelhanos, na face leste da ilha de São Sebastião, em Ilhabela (Imagem 1). Encaixada na ilha, a praia da Figueira tem, aproximadamente, 250 metros de extensão e apresenta uma pequena faixa de areia com agrupamento de rochas em meio a praia (Imagens 2 e 3, obtidas inverno de 2016, fase da lua - lua cheia). Para os desembarques na praia da Figueira, ainda eram necessários o apoio de barcos menores, apesar da maior profundidade que permitia uma aproximação mais segura da embarcação, tornando a trajeto embarcação/praia menos arriscado (CARTA NÁUTICA 1645). Da mesma forma que os africanos desembarcados na praia dos Castelhanos, os aqui desembarcados também poderiam chegar a São Sebastião em embarcações menores e se passarem por ladinos, ludibriando assim, possíveis fiscalizações. Caso necessitassem permanecer na praia da Figueira para recuperação da viagem, era possível construir um abrigo imediatamente após a faixa de areia. Fernando Rangel, o "Formiga", barqueiro que me levou à praia da Figueira, acredita que os africanos que desembarcavam nos "portos" da baía de Castelhanos eram todos levados para a praia da Fome, que fica no extremo norte da ilha, para depois de alimentados e restabelecidos da viagem, alcançarem maior preço nos mercados informais (RANGEL, 2016 com. pess.).

Dissertação de Mestrado

A Diáspora Africana no litoral Norte paulista: desafios e possibilidades de uma abordagem arqueológica. 


\section{PRANCHA 30. Saco do Sombrio}
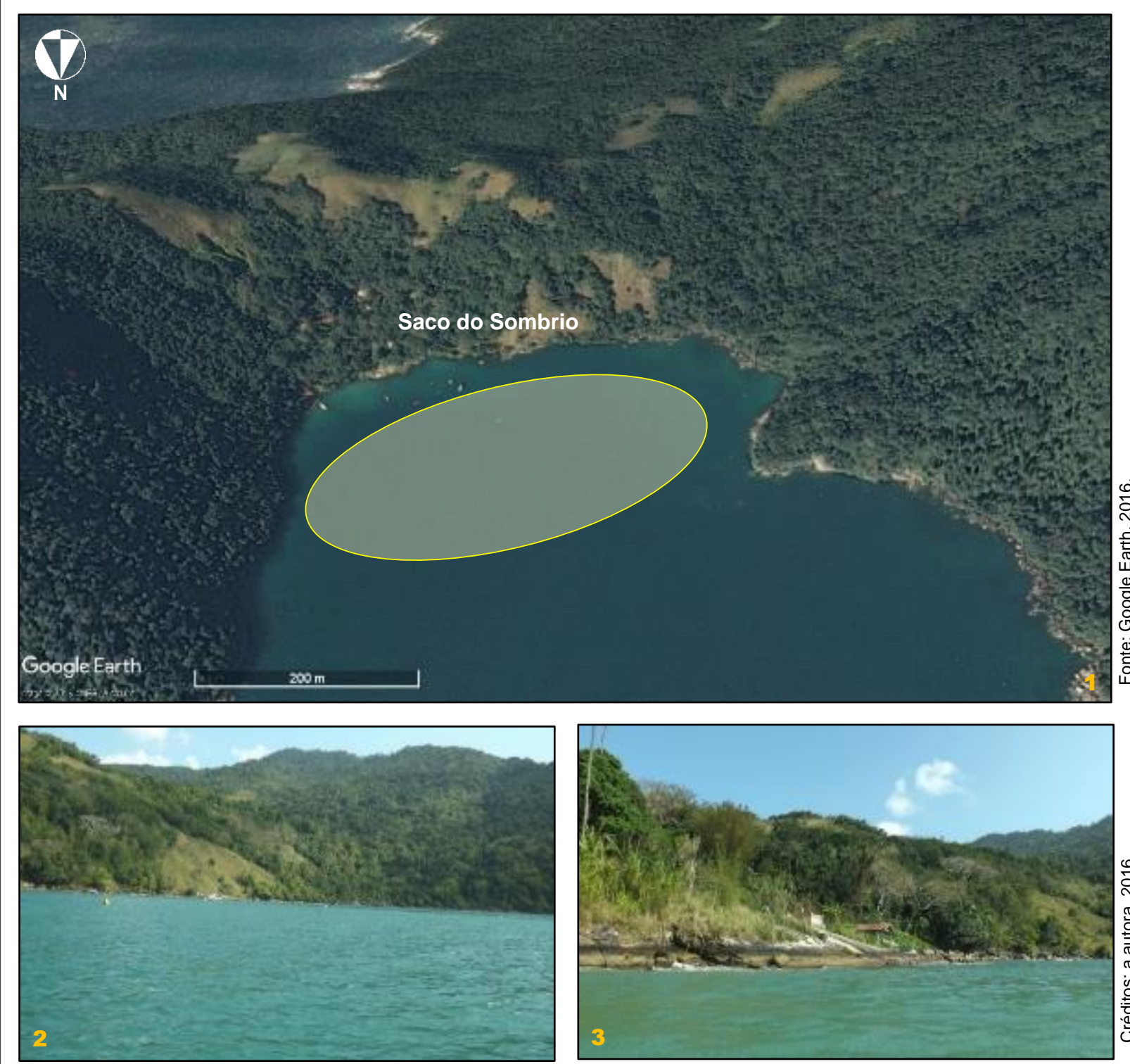

O Saco do Sombrio é um dos locais da baía de Castelhanos mais citados como ponto de desembarque de embarcações negreiras no período da ilegalidade (Imagem 1). Até hoje é possível encontrar embarcações de pesca no Saco do Sombrio esperando o tempo melhorar. Com profundidades na margem em torno de 12 metros (CARTA NÁUTICA 1645), é um local propício para o reparo de embarcações, pois o mar é bastante tranquilo praticamente todo o ano (RANGEL, $2016 \mathrm{com}$. pess). Da mesma forma, para o desembarque dos africanos no período da ilegalidade, a embarcação poderia fazer uma aproximação e realizar o desembarque por pranchas, sem a necessidade de embarcações de apoio. No entanto, para que os africanos saíssem de lá, era necessário que o transporte fosse feito por embarcações menores, visto que os morros do entorno são praticamente intransponíveis. Pequena área com inclinação que ainda permitiria a instalação de estruturas de recepção podem ser encontrada próximo a um costão rochoso mais aplainado na face sul do Saco do Sombrio. De qualquer forma, o "bom negócio" de desembarcar no Saco do Sombrio era apenas para a tribulação das embarcações, pois, de qualquer forma, os africanos recém chegados teriam de enfrentar as águas agitadas da baía de Castelhanos, antes de chegar ao destino final de venda, caso não tivessem sido negociados na ilha. O Saco do Sombrio era um dos locais no qual estavam previstos mergulhos exploratórios, no entanto, a realização dessas ações não foram possíveis. Mas, esse é um local potencial para a aplicação de métodos geofísicos (side scan de varredura lateral e perfilador sísmico) que objetivariam identificar possíveis naufrágios e outros tipos de evidências que poderiam ser associados ao tráfico negreiro, além, é claro, dos mergulhos exploratórios.

Dissertação de Mestrado

A Diáspora Africana no litoral Norte paulista: desafios e possibilidades de uma abordagem arqueológica. 
Como apresentado nas pranchas acima, as prospecções de superfície possibilitaram a obtenção de informações relevantes, que objetivaram elencar alguns parâmetros para que os desembarques clandestinos de africanos tivessem alguma chance de sucesso.

Um dos caminhos buscados, foi checar se os locais indicados como pontos de desembarques eram coincidentes com os locais atualmente indicados como ancoradouros e abrigos temporários. A tabela abaixo (tabela 5) exibe o resultado do cruzamento dessas informações.

Tabela 5. Ancoradouros e abrigos no litoral norte paulista*

\begin{tabular}{|c|c|c|}
\hline $\begin{array}{l}\text { Ancoradouros e } \\
\text { Abrigos (atuais) }\end{array}$ & Ancoradouros (Século XIX ${ }^{147}$ ) & Município \\
\hline Praia de Ubatumirim & Praia de Ubatumirim & Ubatuba \\
\hline \multirow{2}{*}{ Enseada de Picinguaba } & Praia de Picinguaba & \multirow{2}{*}{ Ubatuba } \\
\hline & Praia da Fazenda & \\
\hline Saco do Camburi & & Ubatuba \\
\hline Praia do Félix & & Ubatuba \\
\hline Praia de Itamambuca & & Ubatuba \\
\hline Enseada de Ubatuba & Praia da Barra Seca & Ubatuba \\
\hline Enseada Perequê Mirim & & Ubatuba \\
\hline Enseada do Flamengo & & Ubatuba \\
\hline Enseada da Fortaleza & Praia da Fortaleza & Ubatuba \\
\hline Saco da Ribeira & & Ubatuba \\
\hline Praia de Caraguatatuba & & Caraguatatuba \\
\hline Praia da Armação & & Ilhabela \\
\hline Praia Perequê & & Ilhabela \\
\hline Praia do Guaecá & & São Sebastião \\
\hline \multirow[t]{12}{*}{ Praia de Barequçaba } & & São Sebastião \\
\hline & Ilha dos Porcos & Ubatuba \\
\hline & Praia da Lagoinha & Ubatuba \\
\hline & Ilha do Prumirim & Ubatuba \\
\hline & Praia da Maranduba & Ubatuba \\
\hline & Praia do Bonete & Ubatuba \\
\hline & Praia da Caçandoca & Ubatuba \\
\hline & Illha do Tamanduá & Caraguatatuba \\
\hline & Praia da Tabatinga & Caraguatatuba \\
\hline & Praia de Toque Toque Grande & São Sebastião \\
\hline & Praia da Barra do Sahy & São Sebastião \\
\hline & Praia da Barra do Una & São Sebastião \\
\hline
\end{tabular}

${ }^{147}$ Refiro-me ao século XIX porque é quando ocorre um aumento significativo nos desembarques nas praias, mas, mesmo antes da lei de 1831 alguns desembarques já eram feitos fora dos portos convencionais. 


\begin{tabular}{|c|c|c|}
\hline & Praia de Boracéia & São Sebastião \\
\hline & Praia dos Castelhanos & Ilhabela \\
\hline & Praia da Figueira & Ilhabela \\
\hline & Saco do Sombrio & Ilhabela \\
\hline
\end{tabular}

Na tabela 5 é possível a observação de que dos 20 locais indicados como pontos de desembarque de africanos, cinco desses pontos são atualmente indicados aos navegantes como locais onde é possível sua utilização como ancoradouro ou abrigo. É importante ressaltar que os parâmetros usados, de maneira geral, para a indicação dos pontos atuais se dão principalmente no sentido de que esses locais não estão nas rotas comerciais, não sofrem tanta interferência de alterações meteorológicas e são próximos a costa. Além de considerar os fatores oceanográficos para os pontos associados aos desembarques de africanos escravizados e que foram alvo de prospecções em superfície, foram considerados também características relacionadas à localização e à inserção na paisagem, além de aspectos ambientais e das narrativas orais. Ainda que sem o aprofundamento desejado e longe de propor um "mínimo necessário", apresento na tabela (tabela 6), abaixo, o resumo dessas variáveis, com a finalidade de balizar possibilidades de abordagens arqueológicas:

Tabela 6. Locais passíveis de desembarques e os indicadores avaliados.

\begin{tabular}{|c|c|c|c|c|c|}
\hline $\begin{array}{l}\text { Local indicado como } \\
\text { possível ponto de } \\
\text { Desembarque }\end{array}$ & $\begin{array}{l}\text { Perspectiva } \\
\text { oceanográfica }\end{array}$ & $\begin{array}{l}\text { Abordagem } \\
\text { arqueológica* }\end{array}$ & $\begin{array}{l}\text { Localização e } \\
\text { inserção* }\end{array}$ & $\begin{array}{l}\text { Narrativas } \\
\text { orais }\end{array}$ & Município \\
\hline Praia de Picinguaba & 4 & 1 & 3 & 5 & Ubatuba \\
\hline Praia da Fazenda & 3 & 5 & 3 & 5 & Ubatuba \\
\hline Praia de Ubatumirim & 5 & 1 & 5 & 5 & Ubatuba \\
\hline Praia da Barra Seca & 3 & 1 & 1 & 0 & Ubatuba \\
\hline Praia da Fortaleza & 3 & 1 & 3 & 0 & Ubatuba \\
\hline Praia da Lagoinha & 4 & 1 & 2 & 0 & Ubatuba \\
\hline Praia da Maranduba & 4 & 1 & 2 & 0 & Ubatuba \\
\hline Praia da Caçandoca & 3 & 5 & 3 & 0 & Ubatuba \\
\hline Praia da Tabatinga & 4 & 1 & 2 & 0 & Caraguatatuba \\
\hline Praia de Toque Toque Grande & 3 & 1 & 4 & 5 & São Sebastião \\
\hline Praia da Barra do Sahy & 3 & 1 & 2 & 0 & São Sebastião \\
\hline Praia da Barra do Una & 1 & 1 & 2 & 0 & São Sebastião \\
\hline Praia de Boracéia & 2 & 1 & 2 & 0 & São Sebastião \\
\hline Praia dos Castelhanos & 3 & 5 & 5 & 5 & Ilhabela \\
\hline Praia da Figueira & 4 & 1 & 5 & 0 & Ilhabela \\
\hline Saco do Sombrio & 5 & 1 & 5 & 5 & Ilhabela \\
\hline
\end{tabular}

* valores de 0 a 5 , sendo 0 para nulo e 5 para muito provavelmente. 
$\mathrm{Na}$ tabela acima foram atribuídos valores aos locais associados aos desembarques e alvo de prospecções de superfície. Ratifico que as variáveis foram analisadas sem o aprofundamento desejado e estão baseadas, principalmente, em impressões empíricas, visto a oportunidade das visitas nas etapas de campo realizadas entre 2014 e 2016 . Nesse sentido, conforme indicado na tabela 6, os cinco locais com maior probabilidade de terem sido efetuados desembarques de africanos no período da ilegalidade são: praia dos Castelhanos - em primeiro, praia de Ubatumirim, saco do Sombrio, praia da Fazenda e praia de Toque-Toque Grande, respectivamente.

Além dos locais possivelmente utilizados para os desembarques clandestinos, outros locais associados a ocupação por parte dos africanos durante o regime escravista foram considerados como paisagens da diáspora. Como mencionado anteriormente (item 3.3.1.), a Toca da Josefa foi utilizada provavelmente como local de moradia por muito tempo por uma africana escravizada que havia fugido e se apropriou desse abrigo natural, que está localizado em Ubatuba, nas terras hoje pleiteadas pela Comunidade do Quilombo do Camburi. No município de Ilhabela, em conversa com moradores da praia dos Castelhanos, foi ratificada a história do africano Estevão, já indicada na bibliografia consultada (MERLO, 1997, 2008), a qual aponta que existia uma toca no meio da mata onde esse africano possivelmente se refugiava, e o local é conhecido até os dias de hoje como a "Toca do Estevão". Da mesma forma que essas histórias ainda estavam presentes na memória de alguns moradores, outros locais associados à possível permanência dos africanos escravizados foram checados, sendo apresentadas as impressões preliminares.

\subsubsection{Possíveis conexões}

Nesse sentido, fiz uma abordagem experimental e preliminar mais orientada, a fim de avaliar possíveis conexões existentes entre alguns locais do município de Ubatuba, notadamente entre a praia da Fazenda e a praia de Ubatumirim, localizadas a nordeste do centro urbano.

Com a referência desses lugares em mente, fui até um local em Ubatuba que fica entre a praia de Almada e a praia de Ubatumirim, buscando checar a existência 
de uma gruta possivelmente utilizada como refúgio por africanos fugidos. Acredita-se que os africanos escravizados que haviam sido colocados de castigo em uma pequena ilhota (distante pouco mais de 500 metros desse local), após conseguirem fugir a nado, se escondiam nessa gruta antes de seguirem mata a dentro. Da mesma forma que a gruta, a ilhota do negro também entra nesse hall de referências. Além disso, próximo a essa área, mais precisamente em meio à vegetação da praia Brava de Almada, havia informação de que ruínas de uma construção em pedras muito antiga ainda estavam por lá e ninguém sabia exatamente o que tinham sido, mas que poderiam remeter ao tempo da escravidão. Nesse sentido, fui checar esses locais em busca de identificar possíveis conexões entre eles. Para melhor entendimento, a prancha a seguir (Prancha 31) exibe a espacialização dessa área. 
PRANCHA 31. Possíveis conexões - Ubatuba.

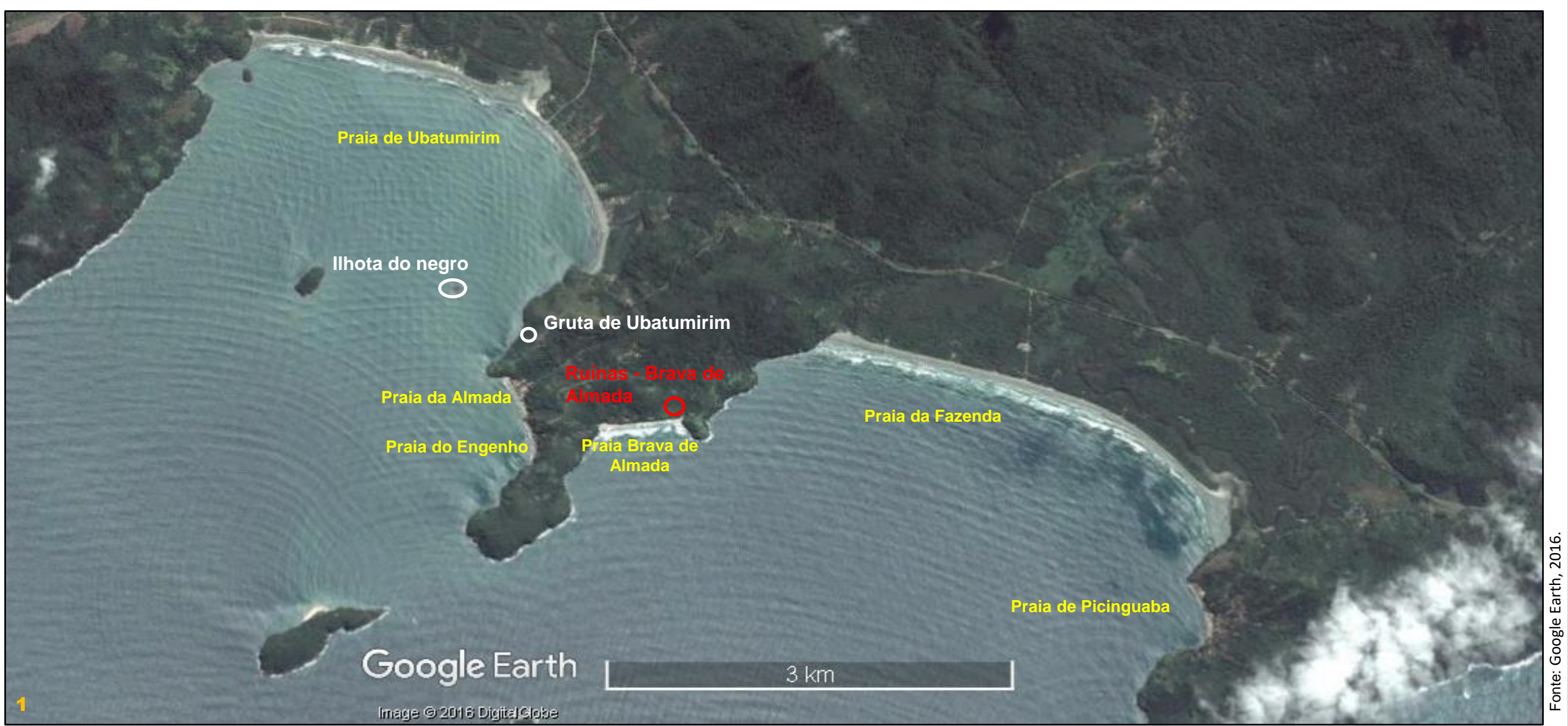

A imagem 1 exibe as três evidências que podem ser associadas a escravidão, além das praias do entorno.

Dissertação de Mestrado

A Diáspora Africana no litoral Norte paulista: desafios e possibilidades de uma abordagem arqueológica. Aluna: Luciana Bozzo Alves

Orientador: Prof. Dr. Pedro Paulo de Abreu Funari

Museu de Arqueologia e Etnologia / USP 
Para chegar até a gruta, que está localizada entre as praias de Almada e de Ubatumirim, foi preciso ir à canoa, e contei com a ajuda de Itamar Marcelino, morador da comunidade de Almada. Depois de, aproximadamente, 15 minutos remando, chegamos a um local no costão rochoso, que, segundo meu condutor, era o ponto que ficava mais próximo da gruta. Esse local já é conhecido pelos moradores, principalmente pelas histórias associadas aos africanos escravizados que escapavam da ilhota do negro. Por causa das chuvas que tinham assolado a região nos últimos dias, o acesso foi bem difícil, em virtude, sobretudo, de um pequeno desmoronamento na encosta do morro, um pouco antes da entrada da gruta. Vencido o obstáculo, a gruta pode ser alcançada e documentada, não como o planejado, mas foi documentada da maneira que foi possível e os detalhes constam na prancha 32.

Com o cair da tarde, não foi possível remarmos até a ilhota do negro, mas ela entra nessa possível conexão com a gruta pois, de acordo com senhor Mandico (morador da praia Brava de Almada), o proprietário do engenho de cana-de-açúcar da praia do Engenho "era um homem muito bravo e cruel" e costumava penitenciar seus "escravos", deixando-os de castigo na pequena ilha (aproximadamente 45 por 45 metros) de pedra e com quase nenhuma vegetação. Lá permaneciam apenas com água até que o dono do engenho achasse que o castigo estava cumprido e, só depois disso, eram reintegrados ao grupo. Por isso, essa ilha ficou conhecida como Ilhota do negro (Prancha 33).

As ruínas em pedras identificadas na praia Brava de Almada estão resumidas a poucas evidências, entre um pilar, fragmentos de muros, possível retificação de um pequeno córrego, além de discretas evidências de um piso de pedra (Prancha 34). No entanto, é uma incógnita a existência desses vestígios. Nenhum dos moradores, nem os mais antigos e nascidos por ali, sabem afirmar com certeza do que se trata. O que ouvi é que essas ruínas estão ali há muito tempo e o fato de não saberem do que se trata, parece que causa um certo incômodo. Em conversas mantidas com o senhor Mandico, que é um dos zeladores da Praia Brava de Almada, desde pequeno ele sabe daquelas pedras, mas ninguém falava o que eram. Ele me disse que "coisa boa não era, senão todo mundo sabia". Depois de muita conversa, ele me falou que existe um pequeno caminho que liga aquele canto onde estão as ruínas até a praia da Fazenda. Foi então que fiz uma associação de que aquelas ruínas podem ser 
remanescentes de estruturas de recepção que abrigavam os africanos que desembarcavam na praia da Fazenda. A praia Brava de Almada tem um mar muito agitado o que tornaria o desembarque extremamente arriscado. No entanto, a construção de estruturas de recepção de grande porte em meio a mata fechada praticamente não levantaria suspeita, pois por terra, até os dias de hoje, há muita dificuldade para se chegar. Além desse caminho que vai da praia da Fazenda até a praia Brava de Almada, que somente os moradores locais conhecem e mesmo assim, poucos utilizam, existe uma trilha que vem da Praia do Engenho e também não é das mais fáceis de se vencer. No século XIX, os acessos deveriam ser muito mais precários e o fato de ser praticamente impossível desembarcar nessa praia, descartaria por completo qualquer suspeita. Nesse sentido, essa estrutura de recepção podia acomodar uma quantidade significativa de africanos, sem chamar a atenção. Outro fator que pode estar associado à segurança que o local traria para esse tipo de empreitada, é a própria matéria-prima com que foi construída, pois a construção em pedras atribui a estrutura um caráter imponente e que impõe certa estabilidade. Com água doce acessível, barreiras naturais a leste e a oeste e uma praia para onde não seria atraída nenhuma embarcação, esse seria um local ideal para a fixação de uma estrutura desse porte sem que se levantasse suspeitas. $O$ fato da memória sobre essa estrutura ter-se "apagado" com o passar dos anos, pode colaborar na sua própria ligação a uma atividade ilegal. 
PRANCHA 32. Gruta de Ubatumirim - Ubatuba
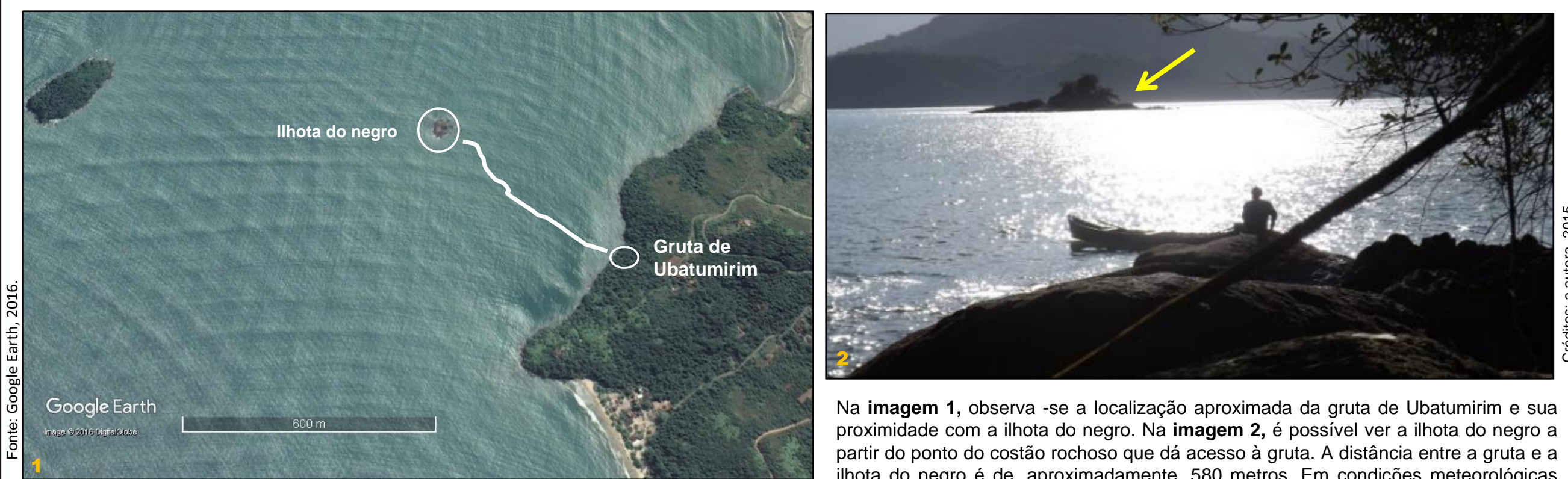

$\mathrm{Na}$ imagem 1, observa -se a localização aproximada da gruta de Ubatumirim e sua proximidade com a ilhota do negro. $\mathrm{Na}$ imagem 2, é possível ver a ilhota do negro a partir do ponto do costão rochoso que dá acesso à gruta. A distância entre a gruta e a ilhota do negro é de, aproximadamente, 580 metros. Em condições meteorológicas
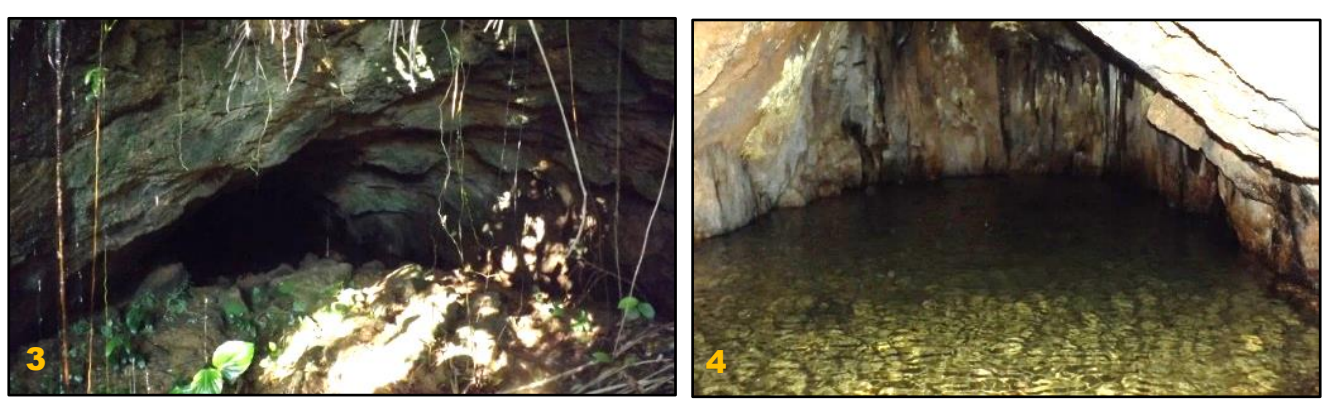
normais, o mar é calmo, com pequenas ondulações apenas próximo ao costão rochoso que dá acesso à gruta. A partir desse ponto, caminha-se por, aproximadamente, 30 metros até chegar a entrada da gruta (Imagem 3) que é esculpida em arenito. Dentro dela (Imagem 4), devido às intensas chuvas nos dias anteriores, havia o acúmulo de água na parte do fundo, no entanto, a porção frontal da gruta permanecia apenas molhada. Era possível ficar sentado sem grande incômodo e seria possível proteger-se da chuva, caso necessário. Pode ser que essa gruta tenha sido utilizada pelos africanos que conseguiam fugir a nado da ilhota do negro, onde eram deixados de castigo, mesmo que ocupassem esta gruta por um curto período de tempo, quiçá, uma noite.

\begin{tabular}{|l|l|}
\hline \multicolumn{2}{|c|}{ Dissertação de Mestrado } \\
\hline \multicolumn{2}{|c|}{$\begin{array}{l}\text { A Diáspora Africana no litoral Norte paulista: } \\
\text { desafios e possibilidades de uma abordagem arqueológica. }\end{array}$} \\
\hline Aluna: Luciana Bozzo Alves \\
\hline Orientador: Prof. Dr. Pedro Paulo de Abreu Funari \\
\hline Museu de Arqueologia e Etnologia / USP & dez/16 \\
\hline
\end{tabular}


PRANCHA 33. Ilhota do Negro - Ubatuba.
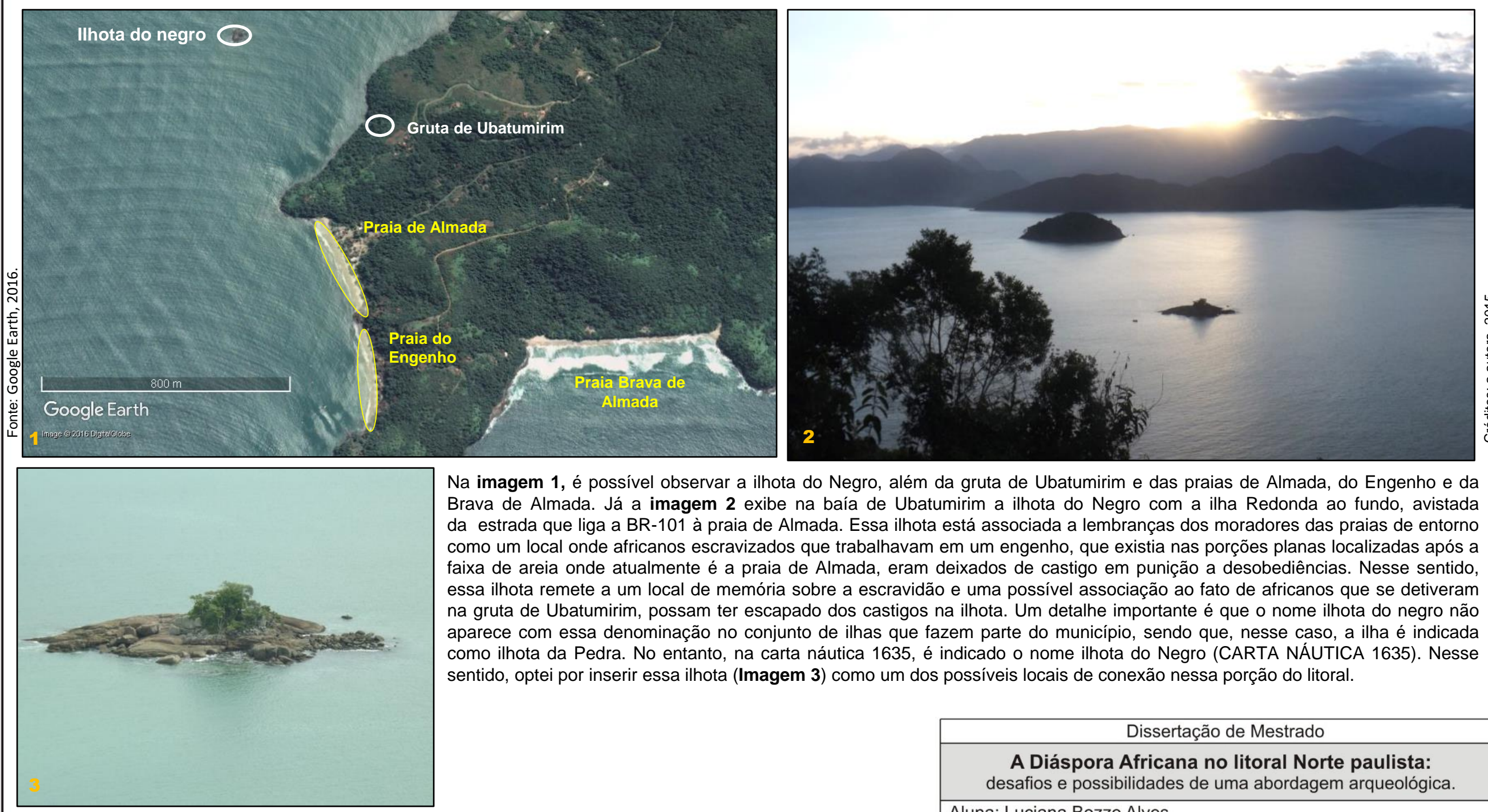

Na imagem 1, é possível observar a ilhota do Negro, além da gruta de Ubatumirim e das praias de Almada, do Engenho e da Brava de Almada. Já a imagem 2 exibe na baía de Ubatumirim a ilhota do Negro com a ilha Redonda ao fundo, avistada da estrada que liga a BR-101 à praia de Almada. Essa ilhota está associada a lembranças dos moradores das praias de entorno como um local onde africanos escravizados que trabalhavam em um engenho, que existia nas porções planas localizadas após a faixa de areia onde atualmente é a praia de Almada, eram deixados de castigo em punição a desobediências. Nesse sentido, essa ilhota remete a um local de memória sobre a escravidão e uma possível associação ao fato de africanos que se detiveram na gruta de Ubatumirim, possam ter escapado dos castigos na ilhota. Um detalhe importante é que o nome ilhota do negro não aparece com essa denominação no conjunto de ilhas que fazem parte do município, sendo que, nesse caso, a ilha é indicada como ilhota da Pedra. No entanto, na carta náutica 1635, é indicado o nome ilhota do Negro (CARTA NÁUTICA 1635). Nesse sentido, optei por inserir essa ilhota (Imagem 3) como um dos possíveis locais de conexão nessa porção do litoral.

\begin{tabular}{|l|l|}
\hline \multicolumn{2}{|c|}{ Dissertação de Mestrado } \\
\hline \multicolumn{2}{|c|}{$\begin{array}{l}\text { A Diáspora Africana no litoral Norte paulista: } \\
\text { desafios e possibilidades de uma abordagem arqueológica. }\end{array}$} \\
\hline Aluna: Luciana Bozzo Alves \\
\hline Orientador: Prof. Dr. Pedro Paulo de Abreu Funari \\
\hline Museu de Arqueologia e Etnologia / USP & dez/16 \\
\hline
\end{tabular}


PRANCHA 34. Ruínas - Brava de Almada - Ubatuba
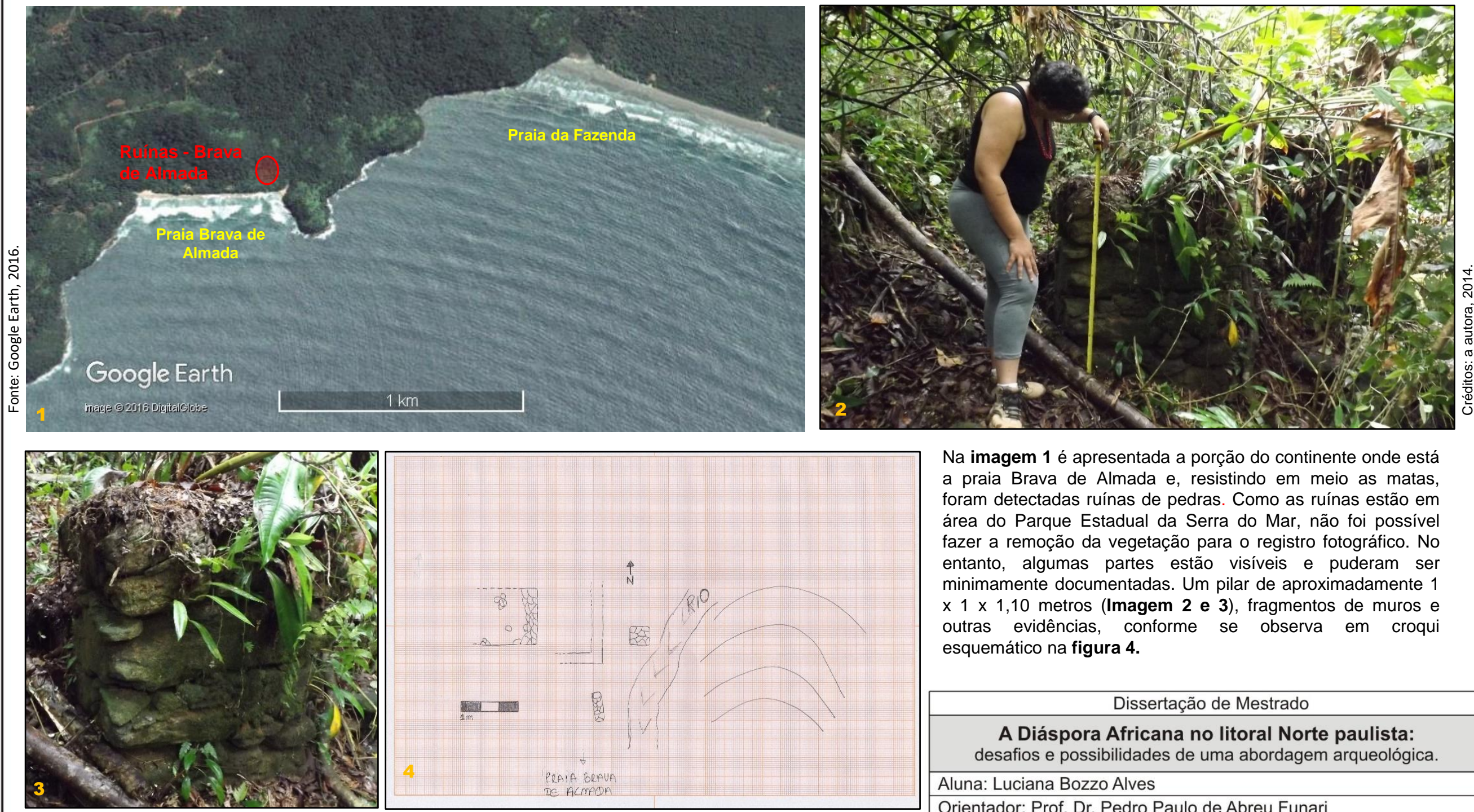

Na imagem 1 é apresentada a porção do continente onde está a praia Brava de Almada e, resistindo em meio as matas, foram detectadas ruínas de pedras. Como as ruínas estão em área do Parque Estadual da Serra do Mar, não foi possível fazer a remoção da vegetação para o registro fotográfico. No entanto, algumas partes estão visíveis e puderam se minimamente documentadas. Um pilar de aproximadamente 1 $\times 1 \times 1,10$ metros (Imagem 2 e 3), fragmentos de muros e outras evidências, conforme se observa em croqui esquemático na figura 4.

\section{Dissertação de Mestrado}

A Diáspora Africana no litoral Norte paulista: desafios e possibilidades de uma abordagem arqueológica. Aluna: Luciana Bozzo Alves

Orientador: Prof. Dr. Pedro Paulo de Abreu Funari 
Nesse sentido, as possibilidades apontadas a partir dos métodos propostos se mostraram promissoras. Os caminhos trilhados carecem de maior aprofundamento, mas, a princípio, se mostraram exequíveis. A interdisciplinaridade utilizada nas abordagens possibilitou a utilização de ferramentas oriundas de áreas da Oceanografia, da Geografia, da História, da Arqueologia, a fim de proporcionar a leitura de grandes compartimentos, objetivando aferir possibilidades, por exemplo, de serem realizados os desembarques de africanos. 


\section{CONSIDERAÇÕES FINAIS}

O litoral Norte paulista teve diferentes aspectos trabalhados na presente dissertação, tais abordagens objetivaram, inicialmente, compreender os processos históricos relacionados à diáspora africana na região partir de uma perspectiva arqueológica. Esforços foram empreendidos no sentido de mapear a documentação concernente ao tráfico de escravos no litoral Norte paulista. Além disso, buscou-se identificar, através da leitura do ambiente e dos recortes nas bordas continentais dos municípios abordados, evidências materiais da diáspora africana. Também serviram de apoio as observações empíricas dos fenômenos abarcados pela Oceanografia nos locais provavelmente destinados aos desembarques de africanos escravizados.

Nesse sentido, o desenvolvimento desse trabalho está imbricado ao desejo de que fenômenos relacionados à Oceanografia possam servir como uma nova fonte de investigação para a Arqueologia da Diáspora Africana, colaborando no entendimento relacionado às dinâmicas envolvidas com 0 tráfico negreiro, notadamente aquelas relacionadas aos desembarques de africanos escravizados realizados fora dos portos convencionais. Além disso, a inclusão das comunidades quilombolas de maneira ativa nas discussões patrimoniais acerca da diáspora africana também está entrelaçada aos propósitos do presente trabalho.

Ao longo do capítulo 1, busquei expor as vertentes teóricas que a Arqueologia trilhou no decorrer do século passado e também como a pluralidade de influências constituiu uma ciência multifacetada, além de expor os caminhos tateados pelo presente trabalho. Busquei apresentar os caminhos trilhados pela Arqueologia Histórica nos últimos tempos, a fim de utilizá-la como ferramenta importante para os processos de descolonização e, da mesma forma, inserir a Arqueologia da Diáspora Africana nesse processo, a partir do fortalecimento das minorias étnicas, nesse caso os africanos e seus descendentes, com o objetivo de evidenciar contribuições positivas na construção da sociedade brasileira, notadamente, pelas evidências materiais e imateriais herdadas, apropriadas, modificadas.

Dentro dessa mesma perspectiva, no capítulo 2, procurei traçar brevemente os processos históricos relacionados ao que se convencionou denominar de diáspora 
africana, tráfico negreiro e escravidão e, como essas questões têm sido abordadas, ainda que de forma tímida, pela Arqueologia Brasileira, desde a década de 1930, até alcançar maior expressão na década de 1980. Essa situação pode ser explicada pelo fato de que a Arqueologia, sempre inserida em um contexto social e político, vivenciou, a partir dessa época questionamentos teóricos, vinculados principalmente ao movimento Pós-processual no âmbito internacional, e, em escala nacional, ter se beneficiado da expansão desses estudos nas ciências humanas e sociais, à abertura do regime democrático e ao próprio movimento negro. Ainda foram trazidos à baila, uma série de trabalhos que abordaram, em maior ou menor intensidade, a Arqueologia da Diáspora Africana. Passando por pesquisas desenvolvidas nos antigos quilombos ou nas comunidades quilombolas que atualmente são reconhecidas pela Constituição de 1988, como donas das terras onde moram, desde que provada sua ancestralidade africana escrava.

No capítulo 3, aspectos relativos as características ambientais dos municípios que compõem o litoral Norte paulista proporcionaram diversas abordagens que, em muitas situações poderiam ser realizadas pela perspectiva da Geografia Cultural e da Arqueologia da Paisagem. No que tange às manifestações culturais mapeadas, a diversidade e importância exibidas parece não refletirem na questão do patrimônio oficializado e/ou reconhecido: há um hiato entre o patrimônio dos municípios em tela reconhecido pelos agentes e comunidades e o patrimônio acautelado pelo estado, visto que as instituições de proteção ao patrimônio, como os museus por exemplo, parecem não valorizar essas vozes. Exceção pode ser feita, em partes, ao município de Caraguatatuba, que procura promover as manifestações culturais relacionadas à herança africana, pelo menos como foi o caso de uma exposição realizada no mês de novembro de 2014, em comemorações ao Dia da Consciência Negra.

As imagens abaixo (Imagens 32, 33 e 34) apresentam o banner apresentando a exposição temporária e o interior do prédio do MACC, com detalhes para alguns dos itens expostos. 


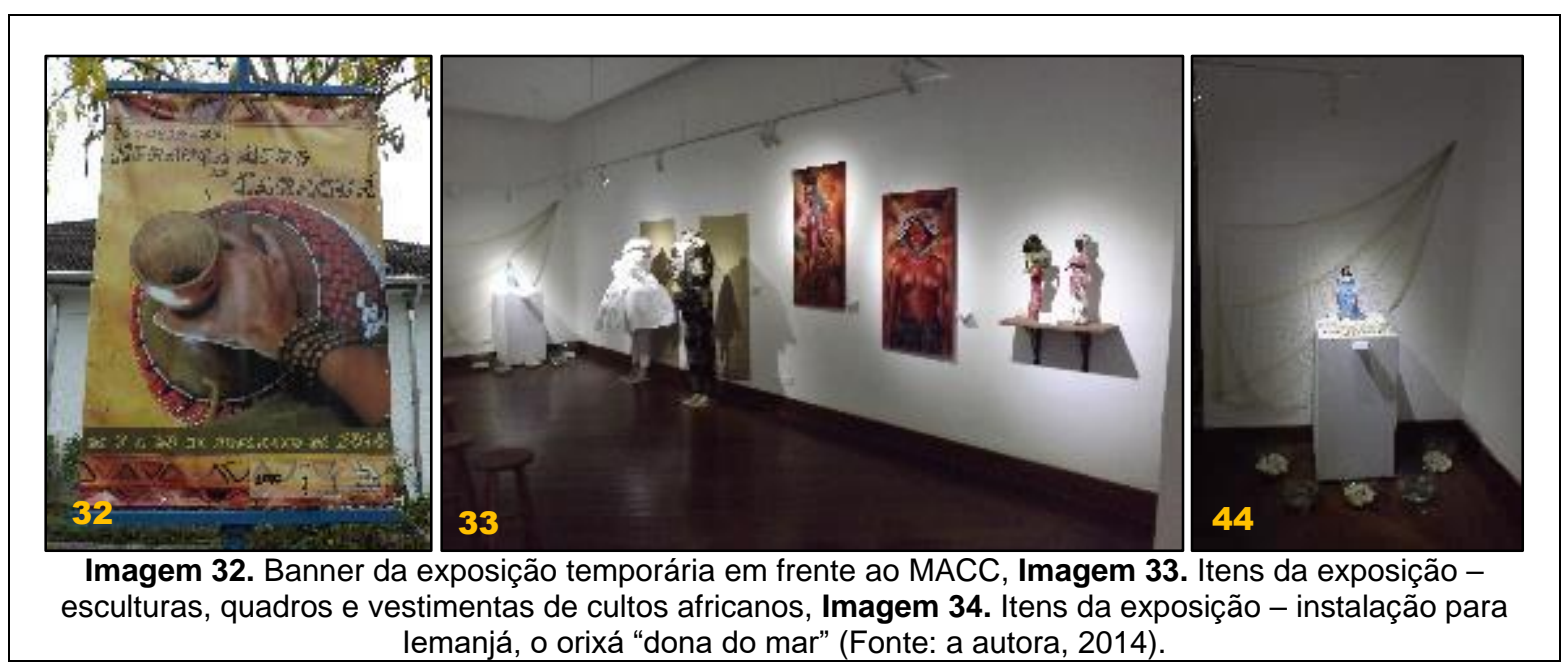

De uma maneira geral, o litoral Norte paulista apresenta-se como uma região com alto potencial para a identificação de sítios arqueológicos, sejam eles relacionados ao período pré-colonial, como os sambaquis, sítios líticos e cerâmicos, ou também aos sítios associados ao período colonial, sejam ruínas das antigas fazendas cafeeiras, dos engenhos de cana-de-açúcar e aguardente, ou também de evidências materiais relacionadas ao tráfico negreiro. Ainda possibilita estudos de cunho etnoarqueológico nas comunidades distribuídas pela área, sejam elas quilombolas ou caiçaras.

Nesse sentido, no capítulo 4 a integração de fontes utilizadas visou ao entendimento das possibilidades de interpretação dos mecanismos relativos ao tráfico negreiro, a fim de indicar possíveis caminhos que levassem a localização de evidências materiais que pudessem ser associadas à diáspora africana. A ousadia foi no sentido de uma leitura do ambiente que não se restringiu ao fator terrestre, pois englobou informações do ambiente aquático ${ }^{148}$, associadas a uma percepção da paisagem no sentido de que "certa invisibilidade" traria sensação de segurança e talvez, imputasse "menos pressa" na execução das atividades relativas aos desembarques e preparo das embarcações para a entrada nos portos convencionais.

\footnotetext{
148 Nesse caso, estou considerando o ambiente marinho e o ambiente dulcícola, pois além das condições oceanográficas que interfeririam diretamente na aproximação das embarcações, o fato de existir ou não fontes de água doce na praia, ou próximas a ela, era considerado fator determinante para o estabelecimento ou não das estruturas de recepção na praia de desembarque.
} 
Dessa forma, foram identificadas, para o município de Ubatuba, onze áreas como possíveis pontos de desembarques, dois pontos em Caraguatatuba, quatro pontos no município de São Sebastião e três pontos no município de Ilhabela. Dos 20 pontos indicados nos textos historiográficos como possíveis locais de desembarques de africanos, 16 foram submetidos a prospecções de superfície. A partir da análise das feições da paisagem, dos aspectos oceanográficos e das narrativas orais, é possível indicar locais de alta probabilidade de desembarques clandestinos, a saber: praia dos Castelhanos em Ilhabela e praia de Ubatumirim em Ubatuba. Da mesma forma, é possível refutar a indicação das praias de Barra do Una, Barra do Sahy e da praia da Boracéia, como pontos de desembarques clandestinos de africanos escravizados, todas localizadas em São Sebastião.

Foi ainda realizada uma abordagem piloto a partir do que foi defendido nesse trabalho e tal investida acabou por apontar locais potenciais com possíveis conexões entre si, localizados a nordeste do centro urbano de Ubatuba. De um lado, a ilhota do negro, onde ainda permeia a lembrança de alguns moradores da praia de Almada, como possível local de punição dos africanos escravizados, que na visão do antigo proprietário do engenho, mereciam ser castigados. De outro lado está a pequena gruta, localizada próxima à ilhota do negro, que pode ter servido de abrigo temporário para os africanos que conseguiam fugir da ilha. Além disso, as evidências de construção em pedras, cujas ruínas foram localizadas na praia Brava de Almada, podem estar associadas a estruturas de recepção de africanos.

Que as possibilidades de abordagens arqueológicas exibidas nesse trabalho, apesar de todos os desafios arrolados, possam colaborar com caminhos profícuos as investigações orientadas pela Arqueologia. Nesse sentido, o presente trabalho aponta caminhos que permitem integrar reflexões e ações pertinentes à Arqueologia Pública, (FUNARI, 2001; MERRIMAN, 2004; FERNANDES, 2007; MORAESWICHERS, 2011) visando à construção de uma Arqueologia multivocal da diáspora africana.

Por fim, buscando fazer uma crítica à visão de que o estado de São Paulo não teria sido palco de desembarques de contingente significativo de africanos escravizados, os levantamentos indicaram que as bordas continentais recortadas dos municípios do litoral Norte do estado de São Paulo foram testemunhas oculares da 
chegada de milhares de africanos, cujas histórias ainda habitam as lembranças de muitos moradores da região. 


\section{Referências Bibliográficas}

ABREU, Martha e PEREIRA Matheus Serva (orgs.). Caminhos da liberdade: histórias da abolição e do pós-abolição no Brasil. Niterói: PPGHistória- UFF, 528 p. 2011.

ABREU, Martha. O caso do Bracuhy. In: Hebe Maria Mattos de Castro \&. Eduardo Schnoor (orgs.). Resgate: uma janela para o oitocentos. Rio de Janeiro: Topbooks, 245 págs. 1995.

ACCIOLI, Nilma Teixeira. José Gonçalves da Silva à Nação Brasileira: $O$ tráfico ilegal de escravos no antigo Cabo Frio. Programa Nacional de Apoio à Pesquisa. Disponível em http://www.bn.br/portal. 2010.

AGOSTINI, C. À Sombra da clandestinidade: práticas religiosas e encontro cultural no tempo do tráfico ilegal de escravos. Vestígios, vol. 7: 75-106. 2013a.

AGOSTINI, Camilla. Objetos da Escravidão: abordagens sobre a cultura material da escravidão e seu legado. 7 Letras, Rio de Janeiro. 2013b.

AGOSTINI, Camilla. Mundo Atlântico e Clandestinidade - Dinâmica material e simbólica em uma fazenda litorânea no Sudeste, século XIX. Tese (Doutorado). Universidade Federal Fluminense - UFF. Instituto de Ciências Humanas e Filosofia Programa de Pós-Graduação em História. Niterói - RJ. 195 págs. 2011 a.

AGOSTINI, Camilla. A vida social das coisas e encantamento do mundo na África Central e Diáspora. Métis (UCS), v. 10, pp. 165-185. 2011 b.

AGOSTINI, Camilla. Práticas religiosas e cultura material à sombra da clandestinidade. In: XXVI Simpósio Nacional de História Anpuh, São Paulo. Anais do XXVI simpósio nacional da ANPUH - Associação Nacional de História. São Paulo: ANPUH - SP. 2011c.

AGOSTINI, Camilla. Cultura material e a experiência africana no sudeste oitocentista: cachimbos de escravos em imagens, histórias, estilos e listagens. Topoi, v. 10, n. 18, jan-jun. pp. 39-47. 2009.

AGOSTINI, Camilla. Resistência cultural e reconstrução de identidades: um olhar sobre a cultura material de escravos do século XIX. Revista de História Regional, v. 3, n.2, pp. 115-137. 1998.

ALLEN, Scott Joseph. Arqueologia da diáspora africana em Alagoas e Pernambuco: problemas e potencialidades. In: AGOSTINI, Camilla. Objetos da escravidão - abordagens sobre a cultura material da escravidão e seu legado. $1^{\underline{a}}$ Edição. Rio de Janeiro: 7Letras, pp. 167-180. 2013.

ALENCASTRO, Luiz Felipe de. O trato dos viventes: formação do Brasil no Atlântico Sul. São Paulo: Cia das Letras. 2000. 
ALMEIDA, A. Wagner B. de. Os quilombos e as novas etnias: é necessário que nos libertemos da definição arqueológica. In: LEITÃO, Sérgio (Org.). Direitos territoriais das comunidades negras rurais. Brasília: Documentos do ISA, n. 5, pp: 1118, 1998.

ALMEIDA, Antonio Paulino de. Memória histórica de São Sebastião. EDUSP: São Paulo. 1959.

ALMEIDA, Fabio Guaraldo. Arqueologia da resistência e etnoarqueologia no território Mandira. Município de Cananéia/SP. Dissertação (Mestrado). Museu de Arqueologia e Etnologia da Universidade de São Paulo. 298 págs. 2012.

ALONSO, Priscila de Lima. O vale do nefando comércio: o tráfico de africanos no vale do Paraíba (1830-1860). Dissertação (Mestrado). São Paulo: FFLCH/USP. 191 págs. 2006.

ALVES, Luciana Bozzo. O desembarque clandestino de africanos escravizados e os desafios de uma abordagem arqueológica. In VXI Congresso da SAB. Goiânia-GO. Caderno de Resumos, pp. 149-140. 2015.

AMARAL, Sharyse Piroupo do. Escravidão, Liberdade e Resistência em Sergipe: Cotinguiba, 1860-1888. Tese (Doutorado). Universidade Federal da Bahia. Salvador, 2007.

AMENOMORI, Sandra Nami. Paisagem das ilhas, as ilhas da paisagem: a ocupação dos grupos pescadores - coletores pré-históricos no litoral norte do Estado de São Paulo. Tese (Doutorado). Universidade de São Paulo, São Paulo. 2005.

ANDRADE, Anna Maria de Castro. Relatório técnico-científico sobre os remanescentes da Comunidade de Quilombo da Fazenda - Ubatuba / São Paulo. Março de 2007.

ANDRADE, Anna Maria de Castro. Relatório técnico-científico sobre os Remanescentes da Comunidade de Quilombo do Sertão de Itamambuca (Cazanga), Ubatuba / São Paulo. Dezembro de 2008.

ANJOS, Giullia Caldas dos; FERREIRA, Lucio Menezes. Arqueologia da Escravidão em Pelotas. XX Congresso de iniciação científica - III Mostra científica UFPEL. 2011.

ARRUTI, J. M. P. A. Mocambo: antropologia e história do processo de formação quilombola. Bauru, SP. EDUSC. 370 págs. 2006.

AZEVEDO, Elciene. O direito dos escravos: Lutas jurídicas e abolicionismo na província de São Paulo. Campinas: Editora da Unicamp, 2010.

BASTOS, Rossano Lopes; SOUZA, Marise Campos de; BORNAL, Wagner Gomes. Sítio Arqueológico Terreiro llê Ñ Zambi. Ficha de Cadastro CNSA. São Paulo: IPHAN 9a. SR, 2011. 
BENDAZZOLI, Cintia. O panorama da ocupação sambaquieira no arquipélago de Ilhabela, SP. Tese (Doutorado). Museu de Arqueologia e Etnologia da Universidade de São Paulo. 2014.

BETHELL, Leslie. A Abolição do comércio brasileiro de escravos, tradução de Luís A. P. Souto Maior. Brasília: Senado Federal, Conselho Editorial, 478 págs. (Coleção biblioteca básica brasileira). 2002.

BEZERRA, Nielson Rosa. O tráfico ilegal e os africanos livres no brasil oitocentista. III Simpósio de história do Maranhão oitocentista. Impressos no Brasil do século XIX. 2013.

BINFORD, Lewis. The archaeology of the place. In: Working at archaeology. New York: Academic Press. 1983.

BOCCIA, Ana Maria Mathias e MALERBI, Eneida Maria. O contrabando de escravos para São Paulo. Revista de História - Ano XXVIII. Vol. LVI. N. ํ 112. OutubroDezembro. 1977.

BORBA, Fernanda Mara. Arqueologia da escravidão numa vila litorânea: vestígios negros em fazendas oitocentistas de São Francisco do Sul (Santa Catarina). Mestrado em Patrimônio Cultural e Sociedade. UNIVILLE. 2013.

BORBA, Fernanda Mara. Arqueologia da escravidão numa vila litorânea: vestígios negros em São Francisco do Sul. Joinville, SC: Editora da UNIVILLE. 207 págs. 2014.

BORELLI, Elizabeth. Quilombolas e Preservação da Natureza. Revista Olhares Sociais, v. 1, pp. 1-15. 2012.

BORNAL, Wagner Gomes. Sítio Histórico São Francisco 01. Contribuição à Arqueologia Histórica. Dissertação (Mestrado). Faculdade de Filosofia, Letras e Ciências Humanas. Museu de Arqueologia e Etnologia da Universidade de São Paulo. 1995.

BORNAL, Wagner Gomes. Sítio Histórico São Francisco. Um estudo sob a ótica da Arqueologia da Paisagem. Tese (Doutorado). Museu de Arqueologia e Etnologia da Universidade de São Paulo. 2008.

BRANCO, Elaine Regina. Encontros, desencontros e reencontros na trajetória da comunidade remanescente do Quilombo Caçandoca: identidade e territorialidade. Dissertação (Mestrado). Universidade Estadual Paulista Júlio de Mesquita Filho, UNESP, Brasil. 2007.

BRUNO, Maria Cristina Oliveira. Processos museológicos: tradições, rupturas e desafios. Apresentação oral no Fórum Patrimônio e Poder. Centro de Convenções da UNICAMP. 2016. 
CALI, Plácido. Políticas Municipais de Gestão do Patrimônio Arqueológico. Tese (Doutorado). Museu de Arqueologia e Etnologia da Universidade de São Paulo. 2005.

CALVENTE, Maria Del Carmen Matilde Huertas. No território do azul-marinho a busca do espaço caiçara. Dissertação (Mestrado). Faculdade de Filosofia, Letras e Ciências Humanas da Universidade de São Paulo. 162 págs. 1993.

CAMPOS, Jurandyr Ferraz de et alli. (org.) Santo Antônio de Caraguatatuba - Memória e Tradições de um povo. Caraguatatuba: FUNDACC, 2000.

CAPONERO, Maria Cristina. Festejando São Benedito: a congada em Ilhabela, recurso cultural brasileiro. Dissertação (Mestrado) Programa Interunidades de Pós-graduação em Estética e História da Arte da Universidade de São Paulo. 2009.

CARDOSO, Beatriz de Barros Vianna e RICCI, Fábio. O desenvolvimento tardio no Litoral Norte de São Paulo: influência da infra-estrutura de transportes Século XVIII a 1960. Revista Ciências Humanas - Universidade de Taubaté (UNITAU) - Brasil - vol. 6, N. 1, 2013.

CARDOSO, Eduardo S. Vitoreiros e Monteiros - Ilhéus no litoral norte paulista. Dissertação (Mestrado) - Departamento de Geografia da Faculdade de Filosofia, Letras e Ciências Humanas. 1996.

CARLE, Cláudio Baptista. A organização espacial dos assentamentos de ocupação tradicional de africanos e descendentes no Rio Grande do Sul, nos séculos XVIII e XIX. Tese (Doutorado). Pontifícia Universidade Católica do Rio Grande do Sul, PUCRS, Brasil. 2005.

CARLE, Cláudio Baptista. Estudos sobre o imaginário na atmosfera de quilombos arqueológicos. Revista de Arqueologia Pública, n.8, dezembro 2013. Campinas: LAP/NEPAM/UNICAMP. 2013a.

CARLE, Cláudio Baptista. Imaginário africano no estudo arqueológico de quilombos. Identidade | São Leopoldo | v.18 n. 2 | p. 160-178 | jul. /Dez. 2013 | ISSN 2178-0437X. 2013b.

CARVALHO, Marcus Joaquim Maciel de. O desembarque nas praias: o funcionamento do tráfico de escravos depois de 1831. Revista de História - São Paulo, no 167, pp. 223-260, julho/ dezembro. 2012

CARVALHO, Patrícia Marinho de. A travessia atlântica de árvores sagradas: Estudos de paisagem e arqueologia em área de remanescente de quilombo em Vila Bela/MT. Dissertação (Mestrado). Museu de Arqueologia e Etnologia da Universidade de São Paulo. 271 págs. 2012.

CARVALHO, Patrícia Marinho de; PORTO, Vagner Cavalheiro. Arqueologia de Quilombo. In. Anais do 10 Congresso de Iniciação Científica, 4⿳亠丷 mostra de PósGraduação e 1ª Mostra do Ensino Médio. 2007. 
CHANTAL, Blanc-Pamard \& RAISON, Jean-Pierre. Paisagem. In: Enciclopédia Einaudi. V. 8. Lisboa: Imprensa Nacional. pp. 138-159. 1986.

CHERQUES, Sérgio. Dicionário do mar. São Paulo: Globo. 1999. 550 págs.

CONRAD, Robert. Tumbeiros: o tráfico de escravos para o Brasil. São Paulo: ed. Brasiliense, 220 págs. 1985.

COSTA, Diogo Menezes. Arqueologia da Diáspora Africana na Amazônia. In: XVIII Congresso da SAB, 2015, Goiânia. Caderno de Resumos, pp. 28-28. 2015.

COSTA, Diogo Menezes. Arqueologia dos Africanos Escravos e Livres na Amazônia. Vestígios - Revista Latino-Americana de Arqueologia Histórica, v. 10, p. 69-91, 2016.

COSTA, Diogo Menezes. Arqueologias históricas: um panorama espacial e temporal. Vestígios. Revista Latino Americana de arqueologia histórica. Volume 4, número 2. Julho-dezembro de 2010.

COSTA, Emília Viotti da. Da senzala a colônia. Editora UNESP, 4aㅡ Edição. 570 págs. 1997.

COSTA, Valéria Gomes. O Recife nas rotas do atlântico negro: tráfico, escravidão e identidades no oitocentos. Revista de História Comparada, Rio de Janeiro, 7,1: 186-217, 2013.

COTTMAN, M. H., The Wrek of the Henrietta Marie. New York, Crown. 1999.

CRUZ, Olga. A serra do Mar e o litoral na área de Caraguatatuba-SP. Contribuição a geomorfologia litorânea tropical. IG. Série Teses e monografias $\mathrm{n}^{\circ} 11$. Universidade de São Paulo. São Paulo, 1974.

CRUZ, Ronaldo Lima da. Tráfico clandestino de escravos: a atuação do Juiz de direito de Ilhéus na apreensão dos africanos desembarcados na praia de Mamoam. Documentação e Memória/TJPE, Recife, PE, v.2, n.3, pp. 119-134, jan/dez. 2010.

DAHER, Carolina dos Santos. Ocupações humanas no Parque Estadual da Serra do Mar: Análise e espacialização dos Autos de Infração Ambiental no Núcleo Caraguatatuba. 102 págs. Dissertação (Mestrado). Escola Superior de Agricultura "Luiz de Queiroz". 2011.

DEAGAN, K. A. Avenues of inquiry in historical archaeology. Advances in Archaeological Method and Theory. In: ORSER, C. E., Jr. (Org.) Images of the recent past: readings in historical archaeology, London: Altamira, p. 16-41, 1996.

DEETZ, J. In Small Things Forgotten. Nova York: Anchoor Books. 1996.

DIEGUES, (Org.). Enciclopédia Caiçara Volume l: O olhar do pesquisador. Editora HUCITEC - NEPAUB-CEC/USP. São Paulo, 2004.

DIEGUES, (Org.). Enciclopédia Caiçara Volume II: Falares Caiçara. Editora HUCITEC - NEPAUB-CEC/USP. São Paulo, 2005. 
DIEGUES, (Org.). Enciclopédia Caiçara Volume V: Festas, Lendas e Mito Caiçara. Editora HUCITEC - NEPAUB-CEC/USP. São Paulo, 2006.

DIEGUES, Antônio Carlos. (Org.) Ilhas e sociedades insulares. São Paulo: NUPAUB-USP. 1997.

DIEGUES, Ilhas e mares: simbolismo e imaginário. São Paulo: Editora Hucitec. 1998.

DRUMMOND, Gaspar de Menezes Vasconcello de. Breve exposição acerca dos factos ocorridos antes, e depois da apprehensão dos africanos efectuada na barra de Serinhãem em outubro de 1855. Recife: Typographia Universal. 87 págs. 1856.

ELLIS, M. A baleia no Brasil Colonial. Ed. Melhoramentos, EDUSP: São Paulo, 235 págs. 1969.

ELTIS, David. Construção do banco de dados do Tráfico de Escravos Transatlântico: fontes e métodos. 2010. Disponível em http://slavevoyages.org/voyage/ acessado em 9 de novembro de 2016.

ENCARNAÇÃO, Márcia Regina Teixeira da. Atlas semântico-lexical de Caraguatatuba, Ilhabela, São Sebastião e Ubatuba - municípios do Litoral Norte de São Paulo. Tese (Doutorado). Faculdade de Filosofia, Letras e Ciências Humanas da Universidade de São Paulo. São Paulo, 741 págs. 2010. 1987.

FAIRBANKS, C. H.; MILANICH, J. T. Florida Archaeology. Orlando: Academic.

FARIA, Ana Maria Reis de. Quilombos \& quilombolas hoje: sobre a reconstrução de conceitos para o ofício da História. Pp. 489-500. In. Abreu et al. ABREU, Martha e PEREIRA Matheus Serva (orgs.). Caminhos da liberdade: histórias da abolição e do pós-abolição no Brasil. Niterói: PPGHistória- UFF, 528 p. 2011.

FEINMAN, G. \& PRICE, D (Eds). Archaeology at the Millennium. Nem York: Kluwer Academic/plenum Publishers. pp. 475-496. 2001.

FELLET, João. O Brasil deveria mudar o modo como lida com a memória da escravidão? Da BBC Brasil em Washington (EUA). 2016. Disponível em http://www.bbc.com/portuguese/brasil-37771180. Acessado em novembro de 2016.

FERNANDES, Tatiana Costa. (2007). Vamos criar um sentimento?! Um olhar sobre a arqueologia pública no Brasil. Dissertação (Mestrado). Universidade de São Paulo.

FERREIRA, Lúcio Menezes. Sobre o conceito de arqueologia da diáspora africana. Métis (UCS), v. 8, pp. 267-277. 2009a

FERREIRA, Lúcio Menezes. Arqueologia da escravidão e Arqueologia Pública: algumas interfaces. Revista latino-americana de arqueologia histórica, v. 3, pp. 7-13. 2009b. 
FIABANI, Adelmir. Mato, palhoça e pilão: $O$ quilombo, da escravidão às comunidades remanescentes [1532-2004]. São Paulo: Expressão Popular, 2005.

FLORENTINO, Manolo. Em costas negras: uma história do tráfico de escravos entre a África e o Rio de Janeiro (séculos XVIII e XIX). São Paulo: Companhia das Letras, 2008.

FONTANA, B. On the Meaning of Historic Sites Archaeology. American Antiquity, n. 31, p. 61-65. 1965.

FRANÇA, Ary. A Ilha de São Sebastião - estudo de Geografia Humana. Universidade de São Paulo. Faculdade de Filosofia, Ciências e Letras. Boletim 178, Geografia nํ 10. 1954.

FUNARI, Pedro Paulo de Abreu \& ORSER, Charles E. Pesquisa arqueológica inicial em Palmares. Estudos Ibero Americanos, Porto Alegre, v. 18, n.2, pp. 53-69. 1992.

FUNARI, Pedro Paulo de Abreu. O amadurecimento de uma arqueologia histórica mundial. In: Revista de História. Departamento de História da Universidade de São Paulo, n. 135, FFLCH-USP, pp.163-168, 1996a.

FUNARI, Pedro Paulo de Abreu. A Arqueologia de Palmares e sua contribuição para o conhecimento da História da Cultura Afro-Americana. In Liberdade por um fio. História dos Quilombos no Brasil. João José Reis e Flávio dos Santos Gomes (org). São Paulo: Cia das Letras, pp. 26-51. 1996b.

FUNARI, Pedro Paulo de Abreu. A "República de Palmares" e a arqueologia da Serra da Barriga. Revista da USP, São Paulo (28): pp. 6-13. Dezembro/fevereiro 95/96. 1996c.

FUNARI, Pedro Paulo de Abreu. O estudo arqueológico do Quilombo de Palmares. In: História em Revista. Publicação do Núcleo de Documentação Histórica da UFPEL. Pelotas: Editora e Gráfica da UFPEL, pp. 201-208. 1996d.

FUNARI, Pedro Paulo de Abreu. Public archaeology from a Latin American perspective. Public Archaeology. London: James \& James Science Publishers, v. 1. pp. 239-243. 2001.

FUNARI, Pedro Paulo de Abreu. Desaparecimento e emergência dos grupos subordinados na Arqueologia brasileira. Horizontes Antropológicos, Porto Alegre, ano 8, n. 18, pp. 131-153, dezembro de 2002.

FUNARI, Pedro Paulo de Abreu; CARVALHO, Aline Vieira de. O patrimônio em uma perspectiva crítica: o caso do Quilombo dos Palmares. Diálogos, Maringá, PR, v. 9, n. 1, pp. 33-48. 2005a.

FUNARI, Pedro Paulo de Abreu. Teoria e métodos na Arqueologia contemporânea: o contexto da Arqueologia Histórica. Mneme Revista de humanidades. Dossiê Arqueologias Brasileiras, v.6, n. 13, dez.2004/jan.2005b. 
FUNARI, Pedro Paulo de Abreu. Teoria e Arqueologia Histórica: a América Latina e o Mundo. Vestígios. Revista Latino-Americana de Arqueologia Histórica. v.1, pp.49 -56. 2007.

FUNES, Eurípedes Antônio. Nasci Nas Matas Nunca Tive Senhor - história e memória dos mocambos do Baixo Amazonas. Regaste Revista de Cultura, CMU/UNICAMP, v. 7, p. 137-142, 1997.

GILROY, Paul. O Atlântico Negro - modernidade e dupla Consciência. Rio de Janeiro, Editora 34/UCAM - Centro de Estudos Afro-Asiáticos. 2002.

GOMES, Abílio Soares. Ondas Marinhas. Disponível em http://www.uff.br/ecosed/ondas. Acessado em 05 de novembro de 2016. 2003.

GOMES, Flávio dos Santos ; MACHADO, Maria Helena. Interiorização e os Quilombos em São Paulo nos Séculos XVIII e XIX. Iberoamericana (Madrid), v. 42, p. 93110, 2011.

GOMES, Flávio dos Santos. História de quilombolas: mocambos e comunidades de senzalas no Rio de Janeiro - século XIX. Dissertação (Mestrado). Universidade Estadual de Campinas - UNICAMP. 639 págs. 1992.

GOMES, Flávio dos Santos. Mocambos e mapas nas Minas: novas fontes para a história social dos Quilombos no Brasil (Minas Gerais Séc. XVIII). Textos de História, Brasília, v. 2, n.4, p. 26-57. 1994.

GOMES, Flávio dos Santos. Em torno dos bumerangues: outras histórias de mocambos na Amazônia colonial. Revista da USP, São Paulo, pp. 40-55. Dezembro/fevereiro 95/96. 1995.

GOMES, Flávio dos Santos. A hidra e os pântanos: quilombos e mocambos no Brasil (séculos XVII - XIX). Tese (Doutorado). Universidade Estadual de Campinas - UNICAMP. 782 págs. 1997.

GOMES, Kathleen. Arqueólogos descobrem destroços de navio negreiro português na África do Sul. Disponível em https://www.publico.pt/culturaipsilon/noticia/arqueologos-descobrem-destrocos-denavio-negreiro-portugues-na-africa-do-sul-1697688. Acessado em 23 de outubro de 2015.

GORDENSTEIN, Samuel Lira. De sobrado a terreiro: a construção de um candomblé na Salvador Oitocentista. Tese (Doutorado). Programa de Pós-Graduação em Antropologia, com área de concentração em Arqueologia Histórica. Universidade Federal da Bahia. 365 págs. 2014.

GUIMARÃES, Carlos Magno. O quilombo do Ambrósio: lenda, documentos e arqueologia. Estudos Ibero-Americanos, Porto Alegre, vol. 16, ํㅜ 1-2. 1990.

GUIMARÃES, Carlos Magno; LANNA, Ana. Arqueologia de quilombos em Minas Gerais. Pesquisas - Antropologia, São Leopoldo, n.31, pp.147-164. 1980. 
HARRINGTON, J. C. Archaeology as an Auxiliary Science of American History. American Anthropologist, v. 57, n. 6, p. 1121-1130. 1955.

HERBERTS, Ana Lucia. Arqueologia do caminho das tropas: estudo das estruturas viárias remanescentes entre os rios Pelotas e Canoas, SC. Tese (Doutorado). Porto Alegre: PUCRS. 2009.

HODDER, Ian. Postprocessual archaeology. Advances in Archaeological Method and Theory, v. 8: pp.1-26. 1985.

HODDER, Ian. Theory and Practice in Archaeology. Routledge, London. 1992.

HODDER, lan. Interpretación en Arqueología - Corrientes actuales. Traducción castellana de Maria José Aubet y J. A. Barceló. Crítica - Grupo GrijalboMondadori - Barcelona. 1994.

HUME, I. N. Historical Archaelogy. New York: Alfred A Knopf. 1969.

LEANDRO, José Augusto. Em águas turvas: navios negreiros na baía de Paranaguá. Em águas turvas: navios negreiros na baía de Paranaguá. Esboços (UFSC), Chapecó, v. 10, pp. 99-117. 2003.

LEITE, Alfredo Carlos Teixeira. O tráfico negreiro e a diplomacia britânica. Caxias do Sul: EDUCS, 554 págs. 1998.

LIMA FILHO, Domingos Leite y ARAUJO Maria do Socorro Gomes. Práticas sociais, trabalho e cultura: ancestralidade, produção do conhecimento e organização das comunidades negras quilombolas do Paraná. XXVI Congreso de la Asociación Latinoamericana de Sociología. Asociación Latinoamericana de Sociología, Guadalajara. Disponível em http://www.aacademica.org/000-066/1011.pdf acessado em 18 de outubro de 2016. 2007.

LIMA, Rossini Tavares de (et al). O folclore do litoral norte de São Paulo. Rio de Janeiro: MEC-SEAC-FUNARTE: Instituto Nacional de Folclore; São Paulo: Secretaria do Estado da Cultura. Universidade de Taubaté, 1981.

LIMA, T. A. Arqueologia Histórica: algumas considerações teóricas (resumo). In: 1ํ Seminário de Arqueologia Histórica (1:1985: Rio de Janeiro). Comunicação. Rio de Janeiro: SPHAN-FNPM, out. 1985.

LIMA, T. A. Arqueologia histórica no Brasil: balanço bibliográfico (1960-1991). Revista de História e Cultura Material. Nova Série, v.1, n. 1, p. 225-262. 1993.

LIMA, T. A. Humores e odores: ordem corporal e ordem social no Rio de Janeiro, século XIX. História, Ciências e Saúde: Manguinhos, v. 2, n. 3, p. 46-98. 1996.

LIMA, T. A.; SENE, G. M.; SOUZA, M. A. T. Em busca do Cais do Valongo, Rio de Janeiro, século XIX. Anais do Museu Paulista. São Paulo. N. Sér. v.24. n.1. p. 299-391. jan.- abr. 2016.

LOURENÇO, Thiago Campos Pessoa. Os Souza Breves e o tráfico ilegal de africanos no litoral sul fluminense. In: Hebe Maria Mattos (org.). Diáspora negra e 
lugares de memórias - a história oculta das propriedades voltadas para o tráfico clandestino de escravos no Brasil imperial. Editora da UFF, 130 págs. 2013.

LUNA, Francisco Vidal \& KLEIN, Herbert S. Evolução da sociedade e Economia Escravista de São Paulo, 1750 a 1850. São Paulo: Editora da Universidade de São Paulo. 280 págs. 2005.

MACHADO, Maria Helena Pereira Toledo. Crime e escravidão. São Paulo: Editora da Universidade de São Paulo. 224 pag. 2014.

MACHADO, Neli Teresinha Galarce. Entre guardas e casarões: um pouco da história do interior do RS - uma perspectiva arqueológica. Tese (Doutorado). Programa de Pós-Graduação em Arqueologia do Museu de Arqueologia e Etnologia da Universidade de São Paulo. 2004.

MACHADO, Théa Mirian Medeiros. et ali. As rotas marítimas do Brasil colônia, os suprimentos e as mercadorias a bordo. Anais do I Simpósio Brasileiro de Cartografia Histórica. 2011.

MAMIGONIAN, Beatriz e GRINBERG, Keila (orgs.). Apresentação. Dossiê: "Para inglês ver?" Revisitando a Lei de 1831. Estudos Afro-Asiáticos, ano 29, nº. 1/ 2/ 3. Rio de Janeiro, jan./dez., p. 87-90. 2007.

MAMIGONIAN, Beatriz G. África no Brasil: mapa de uma área em expansão. Topoi (Rio de Janeiro), Rio de Janeiro, v. 5, n.9, pp. 33-53. 2004.

MARCATO, Gisele Caversan Beltrami; BELTRAMI, Daniele Caversan. Direito às terras das Comunidades Quilombolas: (In)constitucionalidade do Decreto 4.887/2003. ETIC - Encontro de Iniciação Científica. ISSN. 21-76-8498. Volume 11, no 11.2015.

MARCÍLIO, Maria Luiza. Caiçara: terra e população: estudo de demografia histórica e da história social de Ubatuba, 2ª Edição. São Paulo: EDUSP. 2006.

MARQUES, Silvia Correa. Paisagens reveladas: o Jaó caboclo, quilombola, brasileiro. Tese (Doutorado em Arqueologia) - Universidade de São Paulo. 2012.

MATTOS, Hebe (org). Diáspora negra e lugares de memórias - a história oculta das propriedades voltadas para o tráfico clandestino de escravos no Brasil imperial. Editora da UFF, 130 págs. 2013.

MATTOS, Hebe Maria; ABREU, Martha. Remanescentes das comunidades dos Quilombos: memória do cativeiro, patrimônio cultural e direito à reparação. Artigo originalmente publicado em "Iberoamericana: América Latina - Espanha - Portugal", revista do Ibero-Amerikanisches Institut (Berlim), Ano XI (2011) n. 42, Dossiê Novas etnicidades no Brasil: Quilombolas e índios emergentes, coord. por Matthias Röhrig Assunção, pp. 147-160. 2011. 
MATTOS, Hebe. Remanescentes das comunidades dos quilombos: memória do cativeiro e políticas de reparação no Brasil. Revista da USP, São Paulo, n.68, p. 104-111, dezembro/fevereiro 2005-2006.

MATTOS, Hebe; ABREU, Martha; GURAN, Milton. Inventário dos Lugares de Memória do Tráfico Atlântico de Escravos e da História dos Africanos Escravizados no Brasil, $1^{1}$ e ed. Niterói: PPGH-UFF. 111 págs. 2014.

MEDEIROS, Mércia Carréra de. Reconstituição de uma Fazenda Colonial: estudo de caso Fazenda de São Bento de Jaguaribe. Dissertação (Mestrado). Programa de Pós-Graduação em Arqueologia-Conservação do Patrimônio da Universidade Federal de Pernambuco. 2005.

MENESES, U. T. B. de. Identidade Cultural e Arqueologia In: Cultura Brasileira, Temas e Situações, Ática, Série Fundamentos. São Paulo. 1987.

MERRIMAN, Nick. Involving the public in museum archaeology. IN: MERRIMAN, Nick. (2004). Public Archaeology. Londres: Routledge. 2004.

MERLO, Márcia. Congada de Ilhabela: o santo, o homem, a festa, o negro e o lugar. Ângulo (FATEA. Impresso), v. 1, p. 46-53, 2011.

MERLO, Márcia. Entre o mar e a mata: a memória afro-brasileira - São Sebastião, Ilhabela e Ubatuba. São Paulo - FAPESP - EDUC. 301 págs. 2005.

MERLO, Márcia. Ilhabela: suas faces ocultas, suas vozes no ar. Dissertação (Mestrado). Pontifícia Universidade Católica de São Paulo, PUC/SP. 1997.

MESQUITA, Érika. Clóvis Moura (1925-2003). Afro-Ásia (UFBA), Salvador, v. 31, pp. 339-356, 2004.

MORAES-WICHERS, Camila Azevedo de. Patrimônio Arqueológico Paulista: proposições e provocações museológicas. Tese (Doutorado). Museu de Arqueologia e Etnologia da Universidade de São Paulo, 2011.

MORENO, Suzanne Dias e PIRES, Mário Jorge. Mergulho e patrimônio subaquático em Ilhabela: uma análise sob o prisma do Turismo. [Revista Eletrônica de Turismo Cultural] 1‥ Semestre de 2010, Volume 04 - No. 01. 2010.

MUEHE, D. (org.) Erosão e progradação no litoral brasileiro. Brasília: MMA. 476 págs. 2006.

MUEHE, D. O litoral brasileiro e sua compartimentação. In: Cunha, S. B.; Guerra, A. J. T. Geomorfologia do Brasil. Editora Bertrand Brasil, 4⿳亠丷a edição, Rio de Janeiro. 273-350. 2006.

MUNANGA, Kabengele. Origem e histórico do quilombo na África. Revista da USP, no 28: 56-63, São Paulo, dez./fev. de 1995/1996.

NAHAMY, Adriana Sauan et alli. Composição geológica de afloramentos rochosos e impactos ambientais na região de Ilhabela, litoral norte do estado de São Paulo. Disponível em ftp://ftp.sp.gov.br acessado em 21 de dezembro de 2014. 2011. 
NASCIMENTO, Maria Ester Santana Silveira. Quilombo: da ilegalidade a cidadania. XI Congresso Luso Afro Brasileiro de Ciências Sociais. UFBA. 2013.

NÓBREGA, Viviane Martins de Moura. O barro na mão do oleiro [manuscrito]: ressignificações e sensibilidade através da cultura material. Dissertação (Mestrado). Pontifícia Universidade Católica de Goiás, Programa de Mestrado em História. Goiânia, 2014.

NOFFS, Paulo. A disputa da hegemonia do espaço na Baía de Castelhanos. Tese (Doutorado). Faculdade de Filosofia, Letras e Ciências Humanas - Universidade de São Paulo. 261 págs. 2007.

NUCCI, Priscila. Roger Bastide - recriações da sociedade, raça e religião no Brasil (1938-1973). São Paulo: Hucitec, FAPESP. 335 págs. 2013.

OLIVEIRA, O. M. P. \& MARQUES, A. C. Dinâmica sazonal das massas de água no canal de São Sebastião (SE Brasil) de março de 2005 a maio de 2006. XII Congresso Latino-Americano de Ciências do Mar - XII COLACMAR Florianópolis, 15 a 19 de abril de 2007.

OLIVEIRA, Washington de. Ubatuba - documentário. São Paulo: Editora do Escritor, 216 págs. 1977.

ORSER, Charles. Introdução à Arqueologia Histórica. Belo Horizonte: Oficina de Livros. 1992.

ORSER, Charles; FUNARI, Pedro Paulo de Abreu. Arqueologia da resistência escrava. Cadernos do LEPAARQ. Vol. I №. 22004 ISSN 1806-9118. 2004.

ORSER, Charles; FUNARI, Pedro Paulo de Abreu. A pesquisa arqueológica inicial em Palmares. Estudos Ibero-Americanos, Porto Alegre, v.18, n.2, pp.53-69. 1992.

ORSER. Charles E. Introducción a la Arqueología Histórica - Traducción: Andrés Zarankin. 2000.

PAIVA, Zafenathy Carvalho de; FAGUNDES, Marcelo; BORGES, Joina Freitas. "Uma baforada sim sinhô": cachimbos de escravos para se entender as dinâmicas Socioculturais da Diamantina Oitocentista. Revista Tarairiú, v. 09, p. 165186, 2015.

PANIZZA, Andrea de Castro. Imagens orbitais, cartas e coremas: uma proposta metodológica para o estudo da organização e dinâmica espacial - aplicação ao município de Ubatuba, litoral norte, estado de São Paulo, Brasil. Tese (Doutorado). Faculdade de Filosofia, Letras e Ciências Humanas da Universidade de São Paulo. 2004

PAULA, Luís Roberto de. Relatório Técnico-Científico sobre os remanescentes da comunidade de Quilombo de Camburi - Ubatuba-SP. Fundação Instituto de Terras do Estado de São Paulo "José Gomes da Silva". 2002. 
PEREIRA, José Manuel Malhão. Experiências com Instrumentos e métodos antigos de navegação. Comunicação apresentada pelo CMG José Manuel Malhão Pereira, na Academia de Marinha, em 28 de novembro de 2000. Lisboa, 2000.

PEREIRA, Walter Luiz C. de M. Tráfico ilegal de Africanos e conexões Interprovinciais. 5ํ Encontro Escravidão e Liberdade no Brasil Meridional. 16 págs. 2011.

PESSOA, Thiago Campos. O comércio negreiro na clandestinidade: as fazendas de recepção de africanos da família Souza Breves e seus cativos. Afro-Ásia, 47, pp. 43-78. 2013.

PINTO, Moacir. Eu tenho o meu sonho - a sabedoria e os causos do seu Zé Pedro, mestre quilombola da Casa de Farinha de Ubatuba - SP. São Paulo: Editora e distribuidora Suplegraf, 2013.

PLANO DE MANEJO DA SERRA DO MAR. Disponível em http://fflorestal.sp.gov.br/planos-de-manejo/planos-de-manejo-planos. acessado em 07 de novembro de 2016.

PRADO JÚNIOR, Caio. História econômica do Brasil. São Paulo: Brasiliense. 1956.

QUEIROZ, M. I. P. Roger Bastide e o Brasil. O Estado de São Paulo, v. 38, 20 set. 1975.

RAMBELLI, Gilson. Arqueologia de naufrágios e a proposta de estudo de um navio negreiro. Revista de História da Arte e Arqueologia, v. 6, pp. 97-106. 2006a.

RAMBELLI, Gilson. Tráfico e navios negreiros: contribuição da Arqueologia Náutica e Subaquática. Revista Navigator: subsídios para a história marítima do Brasil, v. 2, no 4, pp. 59-72. 2006b.

RAMBELLI, Gilson. A vida social entre o céu e o mar: navios negreiros enquanto artefatos da escravidão. Pp 199-219. 2013. In. AGOSTINI, Camilla. Objetos da Escravidão: abordagens sobre a cultura material da escravidão e seu legado. 7 Letras, Rio de Janeiro. 2013b.

RAMBELLI, Gilson; NOVAES, Luciana de Castro Nunes. Frutos do mar. Revista de História (Rio de Janeiro), v. 1, pp. 29-32. 2011.

RAMOS, Donald. O Quilombo e o sistema escravista em Minas Gerais do século XVIII. In: REIS, João José; GOMES, Flávio dos Santos (Org.). Liberdade por um fio: história dos quilombos no Brasil. São Paulo: Companhia das Letras. pp.164192. 1996.

REDIKER, Marcus. O navio negreiro: uma história humana. Tradução de Luciano Vieira Machado. São Paulo: Companhia das Letras. 446 págs. 2011. 
REIS, Heloisa dos Santos. A relação porto-cidade em São Sebastião no contexto da sua evolução histórico-espacial. Revista Geográfica de América Central. Número Especial EGAL, 2011- Costa Rica, pp. 1-18, II Semestre 2011.

REIS, João José \& GOMES, Flávio dos Santos (org.). Liberdade por um fio história dos quilombos no Brasil. São Paulo: Cia das Letras. 1996a.

REIS, João José \& GOMES, Flávio dos Santos. Introdução: uma história da liberdade. In: REIS, João José \& GOMES, Flávio dos Santos (org.). Liberdade por um fio - história dos quilombos no Brasil. São Paulo: Cia das Letras. 1996b.

REIS, José Alberione dos. Não pensa muito que dói - um palimpsesto sobre Teoria na arqueologia brasileira. Tese (Doutorado). Universidade Estadual de Campinas. 2003.

REIS, Nestor Goulart. Imagens de Vilas e Cidades do Brasil Colonial. São Paulo: Editora da Universidade de São Paulo: Imprensa Oficial do Estado: FAPESP. (Uspiana - Brasil 500 anos). 2000.

RIBEIRO, Marily Simões. Arqueologia das práticas mortuárias: uma abordagem historiográfica. São Paulo: Alameda. 2007

ROCHA, Kenia Nogueira Diógenes da. Relações entre a vulnerabilidade social e a fragilidade ambiental no litoral norte paulista: o caso dos municípios de Ilhabela, São Sebastião, Caraguatatuba e Ubatuba. Dissertação (Mestrado). Universidade Estadual de Campinas. Instituto de Geociências. 2011.

ROCHA, Marcelo Garcia da; MATTOS, Gil Passos de; FERREIRA, Lúcio Menezes. Mapeamento da distribuição espacial de vestígios arqueológicos do período escravista no município de Pelotas, RS (Brasil). XIV ENPOS - Pelotas, RS. 2012.

ROCHA, Tiago de Carvalho Franca et alli. Mapeamento da sensibilidade ambiental do litoral de Ubatuba-SP a vazamentos de petróleo. Revista Brasileira de Cartografia № 63/01. (ISSN 0560-4613). 2010.

RODRIGUES, Jaime. O infame comércio - propostas e experiências no final do tráfico de africanos para o Brasil (1800 a 1850). Editora UNICAMP, 238 págs. 2005.

RODRIGUES, Jaime. De costa a costa - Escravos e tripulantes no tráfico negreiro (Angola - Rio de Janeiro 1780 a 1860). Tese (Doutorado). UNICAMP, 426 págs. 2000.

RODRIGUES, Jaime. Os traficantes de africanos e seu "infame comércio" (1827-1860). Revista Brasileira de História. São Paulo, Vol. 15, no 29. Pp. 139-155. 1995.

ROOS, Adriane Eunice de Paula. A escravidão negra sob a perspectiva do direito no Brasil Imperial. Artigo extraído do Trabalho de Conclusão do Curso de Direito. Disponível em http://www3.pucrs.br. Acessado em 01.01.2015. 2007. 
ROSA, Estefânia Jaékel da. Identidade Afro-brasileira: Um diálogo entre Memória e Cultura material. Revista Memória em Rede, Pelotas, v.2, n.3, ago-nov. 2010.

ROSA, Estefânia Jaékel da. Identidade Afro-brasileira: Um diálogo entre Memória e Cultura material. Dissertação (Mestrado). Universidade Federal de Pelotas. 2012

SAMPAIO, Marcos Guedes Vaz. Uma contribuição à história dos transportes no Brasil: a companhia bahiana de navegação a vapor (1839-1894). Tese (Doutorado). Programa de Pós-Graduação em História Econômica, do Departamento de História da Faculdade de Filosofia, Letras e Ciências Humanas da Universidade de São Paulo. 2006.

SANTAELLA, Lúcia. O que é semiótica? São Paulo: Editora Brasiliense, 2012.

SANTANA, Regina Norma de Azevedo. Mussuca: por uma arqueologia de um território negro em Sergipe D'el Rey. Dissertação (Mestrado). Universidade Federal do Rio de Janeiro - Museu Nacional. 2008.

SANTOS, Edison Luís dos. Estação Memória Cambury: mediação cultural com os parceiros do rio que muda. São Paulo: Dissertação (Mestrado) Programa de Pós-Graduação em Ciência da Informação; Área de concentração: Informação e Cultura). - Escola de Comunicações e Artes da Universidade de São Paulo USP. 2013.

SANTOS, Clayton Galdino. Programa de Gestão do Patrimônio Arqueológico de São Sebastião - SP. Dissertação (Mestrado). Museu de Arqueologia e Etnologia da Universidade de São Paulo. 2012.

SANTOS, Lina. A história do São José veio do fundo do mar e do fundo dos arquivos. Sábado 6 de junho de 2015. Diário de Notícias. Disponível em http://www.dn.pt/artes/interior/a-historia-do-sao-jose-veio-do-fundo-do-mar-e-dofundo-dos-arquivos-4609957.html. Acessado em novembro de 2016.

SANTOS, Luciana de Souza. Sob as águas do rio Sergipe: relação comercial e marítima do porto de Santo Amaro das Brotas/SE a partir do tráfico interno de escravos no século XIX. Monografia de Arqueologia. Universidade Federal de

Sergipe. 2014.

SANTOS, Rita Bernardino Barros; OLIVEIRA, Giovana Carla, ALMEIDA, Valéria Zanetti; BERNARDES, Denis Antonio de Mendonça. Quilombo Sertão do Itamambuca de Ubatuba/SP e suas memórias. In XII Encontro Latino Americano de Iniciação Científica e VIII Encontro Latino Americano de Pós-Graduação Universidade do Vale do Paraíba. 2008.

SAULE JUNIOR, Nelson. Litoral sustentável - desenvolvimento com inclusão social. Resumo executivo de Ubatuba. Instituto Polis, São Paulo, SP. 2012. 
SCATAMACCHIA, M. C \& UCHÔA, D. P. O contato euro-indígena visto através de sítios arqueológicos do Estado de São Paulo. In: Revista de Arqueologia, São Paulo, 7:153-173. 1993.

SCHMITT, Alessandra et alli. A atualização do conceito de quilombo: identidade e território nas definições teóricas. Ambiente \& Sociedade - Ano V - № 10 - 1을 Semestre de 2002.

SCHMITT, Alessandra. Relatório técnico-científico sobre a comunidade de quilombo da Caçandoca, município de Ubatuba / São Paulo. Junho/2000.

SILVA, Alberto da Costa e. Um rio chamado Atlântico: a África no Brasil e o Brasil na África. Rio de Janeiro: Nova Fronteira, Ed. UFRJ. 2003.

SILVA, Armando Correia. O Litoral Norte do Estado de São Paulo. IG/USP, São Paulo. 1975.

SILVA, Bruno Sanches Ranzani da; FRACCARO, Laura Candian. Divers. In. Black. Arqueologia de navios negreiros e identidade. Revista de História da Arte e Arqueologia. Vol. 11. Jan-Jun, pp.127-141. 2009.

SILVA, Cleverson Guizan; PATCHINEELAM, Soraya Maia; BAPTISTA NETO, José Antônio; PONZI, Vera Regina Abelin. Ambientes de sedimentação costeira e processos morfodinâmicos na linha de costa. pp. 175-218. 2004. In. BAPTISTA NETO, José Antônio etti ali. Introdução a geologia marinha. Rio de Janeiro: Interciência. 2004.

SILVA, Fabíola Amaral Jansen da. O cativeiro rural colonial: reconstituição arqueológica da senzala da fazenda de São Bento de Jaguaribe - Município de Abreu e Lima, Pernambuco. - Recife. Dissertação (Mestrado). Universidade Federal de Pernambuco. 2006.

SILVA, Osvaldo Paulino da. Arqueologia dos Engenhos da llha de Santa Catarina - parte sul. Dissertação (Mestrado). Curso de Pós-Graduação em História, concentração em Arqueologia. Instituto de Filosofia e Ciências Humanas da Pontifícia Universidade Católica do Rio Grande do Sul. 287 págs. 1996.

SILVA, Ricardo Tadeu Caires. O fim do tráfico atlântico de escravos e a política de alforrias no Brasil. In: VI Seminário do Trabalho, Marília. Trabalho, economia e educação no século XXI. 2008.

SILVEIRA, Ilson Carlos Almeida da, SCHMIDT, André Campos Kersten; CAMPOS, Edmo José Dias; GODOI, Sueli Susana de \& IKEDA, Yoshimine. A Corrente do Brasil ao Largo da Costa Leste Brasileira. Revisão. Revista Brasileira de Oceanografia. 48(2):171-183. 2000.

SINGLETON, T. A., \& SOUZA, M. A. Archaeologies os the African Diaspora: Brazil, Cuba, and the United States. In: Teresita majewski; David Gaimster. (Org.). International Handbook of Historical Archaeology. 1ed.New York: Springer, 2009, v. pp. 449-469. 2009. 
SINGLETON, Theresa A. Reflexões sobre a Arqueologia da Diáspora Africana no Brasil. Vestígios. Revista Latino Americana de Arqueologia Histórica, v. 7, pp. 211 219. 2013.

SOUSA, Paulo Henrique Gomes de Oliveira. Erosão Costeira. Disponível em http://www.io.usp.br/index.php/oceanos/textos/gestao-costeira/70-portugues/publica coes/series-divulgacao/gestao-costeira/969-erosao-costeira. Acesso em 12 de novembro de 2016. S/D.

SOUSA, Denise Martins de; SUZUKI, Júlio César. Transformações do modo de vida tradicional Caiçara da comunidade São Paulo-Bagre, Cananéia-SP. Anais do XVI Encontro Nacional dos Geógrafos. ENG. Porto Alegre, 2010.

SOUZA, BARBARA OLIVEIRA. Movimento Quilombola: Reflexões sobre seus aspectos político-organizativos e identitários. In: 26aㅡ Reunião Brasileira de Antropologia, 2008, Porto Seguro, Bahia, Brasil. Anais da 26 $6^{\underline{a}}$ Reunião Brasileira de Antropologia, 2008.

SOUZA, Celia Regina de Gouveia; LUNA, Graciele da Costa. Taxas de retrogradação e balanço sedimentar em praias sob risco muito alto de erosão no município de Ubatuba (Litoral Norte de São Paulo). Quaternary and Environmental Geosciences, v. 1, p. 25-41, 2009.

SOUZA, L. A. P. Revisão crítica da aplicabilidade dos métodos geofísicos na investigação de áreas submersas rasas, Tese (Doutorado), Universidade de São Paulo, São Paulo. 2006.

SOUZA, Marcos André Torres de. Uma outra escravidão: a paisagem social no Engenho de São Joaquim. Vestígios. Revista Latino-Americana de Arqueologia Histórica, v. 1, p. 59-92, 2007.

SOUZA, Marcos André Torres de. (2011). A vida escrava portas adentro: uma incursão às senzalas do Engenho de São Joaquim, Goiás, século XIX. Maracanan, v. 7, pp. 83-109, 2011.

SOUZA, Marcos André Torres de. Introdução: Arqueologia da Diáspora Africana no Brasil. Vestígios. Revista Latino Americana de Arqueologia Histórica, v. 7, pp. 9-19. 2013a.

STOVEL, E. The Archaeology of Identity Construction: Ceramic Evidence from Northern Chile. In: FUNARI, P. P. A.; ZARANKIN, A.; STOVEL, E. (Org.) Global archaeological theory: contextual voices and contemporary thoughts. New York: Kluwer Academic/Plenum, p. 145-166. 2005.

SUGUIO, Kenitiro. Dicionário de geologia sedimentar e áreas afins. Rio de Janeiro: Bertrand Brasil, 1998.

SVALESEN, Leif. The Slave Ship Fredensborg. Indiana University Press (November 22, 2000). 
SYMANSKI, Luís Cláudio Pereira. O Domínio da tática - práticas religiosas de origem Africana nos engenhos de Chapada dos Guimarães (MT); Vestígios - Revista Latino-Americana de Arqueologia Histórica. Volume 1 | Número 2 | julho - dezembro 2007.

SYMANSKI, Luís Cláudio Pereira. A Arqueologia da Diáspora Africana nos Estados Unidos e no Brasil: Problemáticas e Modelos. Afro-Ásia, vol. 49: pp 159-198. 2014

SYMANSKI, Luís Cláudio Pereira; GOMES, Flávio. Arqueologia da escravidão em fazendas jesuíticas: primeiras notícias da pesquisa. História, Ciências, Saúde Manguinhos, Rio de Janeiro, v.19, supl, pp. 309-317. dez. 2012.

SYMANSKI, Luís Cláudio Pereira; GOMES, Flávio. Da cultura material da escravidão e do pós-emancipação: perspectivas comparadas em arqueologia e história. Revista de História Comparada, Rio de Janeiro, 7,1: pp.293-338. 2013

SYMANSKI, Luís Cláudio Pereira; SOUZA, Marcos André Torres de. O registro arqueológico dos grupos escravos: questões de visibilidade e preservação. Revista do Patrimônio Histórico e Artístico Nacional. 33: pp. 215-244. 2007.

SYMANSKI, Luís Cláudio Pereira; ZANETTINI, Paulo Eduardo. Encontros culturais e etnogênese: o caso das comunidades afro-brasileiras do Vale do Guaporé. Vestígios. Revista latino-americana de Arqueologia Histórica, v. 4, pp. 89-124. 2010.

TAVARES, Aurea Conceição Pereira. Vestígios materiais nos enterramentos na antiga Sé de Salvador: postura das instituições religiosas africanas frente à igreja católica em Salvador no período escravista. Dissertação (Mestrado). Universidade Federal de Pernambuco. 2006.

TAVARES, Reinaldo Bernardes. Cemitério dos pretos novos, Rio de Janeiro, século XIX: uma tentativa de delimitação espacial. Dissertação (Mestrado). Programa de Pós-Graduação em Arqueologia do Museu Nacional, Rio de Janeiro. 2012.

TEDESCO, Gislaine Valério de Lima. Do lado de lá e do lado de cá de Vila Boa de Goiás: Fronteiras Culturais e espaciais entre negros e brancos no século XIX. In: 4ํEcontro Escravidão e Liberdade no Brasil Meridional. Curitiba, pp. 1-10. 2009.

TESSLER, M. G. \& SOUZA L. A. P., Dinâmica sedimentar e feições sedimentares identificadas na superfície de fundo do sistema Cananéia-Iguape, SP. Revista Brasileira de Oceanografia. 46(1): pp 69-83. 1998.

TESSLER, M. G.; CAZZOLI Y GOYA, S. V.; YOSHIKAWA, P. S.; HURTADO, S. N. Erosão e progradação do litoral do estado de São Paulo. In: MUEHE, D. (Org.). Erosão e Progradação do litoral brasileiro. 1ed.Brasilia: Ministério do Meio Ambiente, v, p. 297-346. 2006.

THIESEN, Beatriz Valladão, Claudia Daiane MOLET, e Marcia Naomi KUNIOCHI. Charqueada e escravidão em Rio Grande. In: 5 Encontro Escravidão e Liberdade no Brasil Meridional. Porto Alegre: URGS, pp. 1- 15. 2011. 
TINNIE, Dinizulu Gene. A Slave Ship Speaks - The Wreck of the Henrietta Marie. Disponível em http://www.historical-museum.org/exhibits/hm/sss.htm acessado em 02 de novembro de 2016. S/D.

TOMAZ, Laycer. Da senzala a capela. Editora Universidade de Brasília. 2000.

TRECCANI, Girolamo Domenico. Terras de quilombo: caminhos e entraves do processo de titulação. 1. ed. Belém: autor. 344 págs. 2006.

TRIGGER, Bruce G. História do pensamento Arqueológico. Tradução: Ordep Trindade Serra. São Paulo: Odysseus Editora. 477 págs. 2004.

UCHÔA, D. P. Coletores Pescadores do Litoral Meridional Brasileiro. In: Revista de História. Vol. VI, 104-106. 1984.

UCHÔA, D. P. Ocupação do litoral sul-sudeste brasileiro por grupos coletor pescadores holocênicos. Arquivo do Museu de História Natural, Belo Horizonte, v. 6/7, p.133-143. 1981/1982.

UCHÔA, D. P. Sinopse do "Arcaico do Litoral de São Paulo". Anuário de Divulgação Científica 7. Instituto Goiano de Pré-História e Antropologia. Universidade Católica de Goiás. Goiânia. 1980.

VERGER, Pierre. Fluxo e Refluxo do tráfico de africanos entre o Golfo do Benin e a Bahia de todos os Santos nos séculos XVII e XIX, $3^{\text {a }}$ ed., São Paulo: Currupio. 1987.

WEBSTER, Janet. Slave ships and maritime archaeology: an overview, International Journal of Historical Archaeology, vol. 12, no 6, pp. 6-19. 2008.

YABETA, Daniela; GOMES, Flávio. Memória, cidadania e direitos de comunidades remanescentes (em torno de um documento da história dos quilombolas da Marambaia). Afro-Ásia, 47, pp. 79-117. 2013.

ZANETTINI, Paulo Eduardo. Maloqueiros em seus palácios de barro: o cotidiano doméstico na casa bandeirista. Tese (Doutorado). Museu de Arqueologia e Etnologia da Universidade de São Paulo. 424 págs. 2005.

ZANETTINI ARQUEOLOGIA. Projeto de Avaliação de Impacto ao Patrimônio Arqueológico - Ampliação do Centro de Disposição de Resíduos Ltda (CDR Pedreira), Município de São Paulo, Estado de São Paulo. 2015

ZARANKIN, A. \& SENATORE, M. X. (orgs.). Arqueologia da sociedade moderna na América do Sul. Cultura material, discursos e práticas. Buenos Aires, Ediciones del Tridente, Colección Científica, 2002.

ZARANKIN, A. Casa tomada: sistema, poder y vivienda doméstica. In: Acuto, F. A. (Org.) Sed non satiata: teoría social em la arqueología latinoamericana contemporánea. Buenos Aires: Del Tridente, pp. 239-272, 1999. 


\section{Sites pesquisados}

Banco de Dados do tráfico Transatlântico de Escravos. Disponível em http://slavevoyages.org. Acessado em outubro de 2016.

Comissão pró-Índio de São Paulo. Disponível em http://www.cpisp.org.br. Acessado em junho de 2016.

Conselho de Defesa do Patrimônio Histórico Arqueológico, Artístico e Turístico. Disponível em www.condephaat.sp.gov.br. Acessado em novembro de 2016.

Fundação Cultural Palmares. Disponível em http://www.palmares.gov.br/. Acessado em novembro de 2016.

FUNDART - Fundação de Arte e Cultura de Ubatuba. Disponível em http://fundart.com.br/. Acessado em junho de 2016.

GELEDÉS - Instituto da Mulher Negra. Disponível em http://www.geledes.org.br/. Acessado em junho de 2016.

Instituto Brasileiro de Geografia e Estatística. Disponível em http://www.ibge.gov.br/home/. Acessado em novembro de 2016.

Navio Negreiro Trouvadore. Disponível em http://slaveshiptrouvadore.org/ acessado em novembro de 2016.

Secretaria da Cultura do Governo do Estado de São Paulo. Disponível em http://www.cultura.sp.gov.br. Acessado em junho de 2016.

Secretaria do Meio Ambiente. Disponível em http://www.ambiente.sp.gov.br/. Acessado em novembro de 2016.

The Atlantic Slave Trade and Slave Life in the Americas: a visual record. Disponível em http://slaveryimages.org/. Acessado em novembro de 2016. 
ANEXO 1. Locais indicados como possíveis pontos de desembarques - Fontes consideradas. 


\begin{tabular}{|c|c|c|}
\hline Local de desembarque & Município & Fonte \\
\hline Praia da Lagoinha & Ubatuba - SP & $\begin{array}{l}\text { ALONSO, Priscila de Lima. O vale do nefando comércio: o tráfico de africanos no vale do Paraíba (1830- } \\
\text { 1860). Dissertação de Mestrado. São Paulo: Faculdade de Filosofia, Letras e Ciências Humanas/USP. } 191 \\
\text { págs. } 2006 .\end{array}$ \\
\hline \multirow{3}{*}{ Não indicado } & Ubatuba - SP & $\begin{array}{l}\text { AGOSTINI, Camilla. Mundo Atlântico e Clandestinidade - Dinâmica material e simbólica em uma fazenda } \\
\text { litorânea no sudeste, século XIX. Tese de doutorado. Universidade Federal Fluminense - UFF. Instituto de } \\
\text { Ciências Humanas e Filosofia Programa de Pós-Graduação em História. Niterói - RJ. } 195 \text { págs. } 2011 .\end{array}$ \\
\hline & Ubatuba - SP & $\begin{array}{l}\text { ALONSO, Priscila de Lima. O vale do nefando comércio: o tráfico de africanos no vale do Paraíba (1830- } \\
\text { 1860). Dissertação de Mestrado. São Paulo: Faculdade de Filosofia, Letras e Ciências Humanas/USP. } 191 \\
\text { págs. } 2006 .\end{array}$ \\
\hline & Ubatuba - SP & $\begin{array}{c}\text { RODRIGUES, Jaime. O infame comércio - propostas e experiências no final do tráfico de africanos para o } \\
\text { Brasil (1800 a 1850). }\end{array}$ \\
\hline Praia Barra Seca & Ubatuba - SP & $\begin{array}{c}\text { RODRIGUES, Jaime. O infame comércio - propostas e experiências no final do tráfico de africanos para o } \\
\text { Brasil (1800 a 1850). }\end{array}$ \\
\hline Praia de Fortaleza & Ubatuba - SP & OLIVEIRA, Washington de. Ubatuba - documentário \\
\hline \multirow{2}{*}{ Praia da Caçandoca } & Ubatuba - SP & OLIVEIRA, Washington de. Ubatuba - documentário \\
\hline & Ubatuba - SP & José Vieira (Zé Pedro) \\
\hline \multirow{2}{*}{ Praia de Ubatumirim } & Ubatuba - SP & OLIVEIRA, Washington de. Ubatuba - documentário \\
\hline & Ubatuba - SP & José Vieira (Zé Pedro) \\
\hline Praia de Maranduba & Ubatuba - SP & $\begin{array}{l}\text { ALONSO, Priscila de Lima. O vale do nefando comércio: o tráfico de africanos no vale do Paraíba (1830- } \\
\text { 1860). Dissertação de Mestrado. São Paulo: Faculdade de Filosofia, Letras e Ciências Humanas/USP. } 191 \\
\text { págs. } 2006 .\end{array}$ \\
\hline Praia da Lagoinha & Ubatuba - SP & $\begin{array}{c}\text { BOCCIA, Ana Maria Mathias e MALERBI, Eneida Maria. (1977). O contrabando de escravos para São Paulo. } \\
\text { Revista de História - Ano XXVIII. Vol. LVI. N. ํ 112. Outubro-Dezembro. }\end{array}$ \\
\hline Praia do Bonete & Ubatuba - SP & $\begin{array}{l}\text { MARCÍLIO, Maria Luiza. Caiçara: terra e população: estudo de demografia histórica e da história social de } \\
\text { Ubatuba }\end{array}$ \\
\hline \multirow{4}{*}{ Praia da Fazenda } & Ubatuba - SP & José Vieira (Zé Pedro) \\
\hline & Ubatuba - SP & Benedito Correia da Silva (Pu) \\
\hline & Ubatuba - SP & Benedito Conceição (Dico) \\
\hline & Ubatuba - SP & Irmandino de Souza (Mandico) \\
\hline Praia de Prumirim & Ubatuba - SP & Elias Lopes de Oliveira \\
\hline Praia de Picinguaba & Ubatuba - SP & José Vieira (Zé Pedro) \\
\hline Ilha dos Porcos & Ubatuba - SP & Irmandino de Souza (Mandico) \\
\hline
\end{tabular}




\begin{tabular}{|c|c|c|}
\hline Local de desembarque & Município & Fonte \\
\hline \multirow{3}{*}{ Não indicado } & Caraguatatuba - SP & $\begin{array}{l}\text { AGOSTINI, Camilla. Mundo Atlântico e Clandestinidade - Dinâmica material e simbólica em uma fazenda } \\
\text { litorânea no sudeste, século XIX. Tese de doutorado. Universidade Federal Fluminense - UFF. Instituto de } \\
\text { Ciências Humanas e Filosofia Programa de Pós-Graduação em História. Niterói - RJ. } 195 \text { págs. } 2011 .\end{array}$ \\
\hline & Caraguatatuba - SP & $\begin{array}{l}\text { ALONSO, Priscila de Lima. O vale do nefando comércio: o tráfico de africanos no vale do Paraíba (1830- } \\
\text { 1860). Dissertação de Mestrado. São Paulo: Faculdade de Filosofia, Letras e Ciências Humanas/USP. } 191 \\
\text { págs. } 2006 .\end{array}$ \\
\hline & Caraguatatuba - SP & $\begin{array}{c}\text { RODRIGUES, Jaime. O infame comércio - propostas e experiências no final do tráfico de africanos para o } \\
\text { Brasil (1800 a 1850). }\end{array}$ \\
\hline \multirow[t]{2}{*}{ Praia de Tabatinga } & Caraguatatuba - SP & $\begin{array}{l}\text { ALONSO, Priscila de Lima. O vale do nefando comércio: o tráfico de africanos no vale do Paraíba (1830- } \\
\text { 1860). Dissertação de Mestrado. São Paulo: Faculdade de Filosofia, Letras e Ciências Humanas/USP. } 191 \\
\text { págs. } 2006 .\end{array}$ \\
\hline & Caraguatatuba - SP & $\begin{array}{l}\text { MARCÍLIO, Maria Luiza. Caiçara: terra e população: estudo de demografia histórica e da história social de } \\
\text { Ubatuba }\end{array}$ \\
\hline \multirow[t]{4}{*}{ Ilha do Tamanduá } & Caraguatatuba - SP & $\begin{array}{l}\text { BOCCIA, Ana Maria Mathias e MALERBI, Eneida Maria. (1977). O contrabando de escravos para São Paulo. } \\
\text { Revista de História - Ano XXVIII. Vol. LVI. N. ํ 112. Outubro-Dezembro. }\end{array}$ \\
\hline & São Sebastião - SP & $\begin{array}{l}\text { ALONSO, Priscila de Lima. O vale do nefando comércio: o tráfico de africanos no vale do Paraíba (1830- } \\
\text { 1860). Dissertação de Mestrado. São Paulo: Faculdade de Filosofia, Letras e Ciências Humanas/USP. } 191 \\
\text { págs. } 2006 .\end{array}$ \\
\hline & São Sebastião - SP & $\begin{array}{c}\text { RODRIGUES, Jaime. O infame comércio - propostas e experiências no final do tráfico de africanos para o } \\
\text { Brasil (1800 a 1850). }\end{array}$ \\
\hline & São Sebastião - SP & $\begin{array}{l}\text { AGOSTINI, Camilla. Mundo Atlântico e Clandestinidade - Dinâmica material e simbólica em uma fazenda } \\
\text { litorânea no sudeste, século XIX. Tese de doutorado. Universidade Federal Fluminense - UFF. Instituto de } \\
\text { Ciências Humanas e Filosofia Programa de Pós-Graduação em História. Niterói - RJ. } 195 \text { págs. } 2011 .\end{array}$ \\
\hline \multirow[t]{2}{*}{ Praia da Barra do Sahy } & São Sebastião - SP & $\begin{array}{c}\text { ALONSO, Priscila de Lima. O vale do nefando comércio: o tráfico de africanos no vale do Paraíba (1830- } \\
\text { 1860). Dissertação de Mestrado. São Paulo: Faculdade de Filosofia, Letras e Ciências Humanas/USP. } 191 \\
\text { págs. } 2006 .\end{array}$ \\
\hline & São Sebastião - SP & $\begin{array}{c}\text { RODRIGUES, Jaime. O infame comércio - propostas e experiências no final do tráfico de africanos para o } \\
\text { Brasil (1800 a 1850). }\end{array}$ \\
\hline Praia de Boracéia & São Sebastião - SP & $\begin{array}{l}\text { ALONSO, Priscila de Lima. O vale do nefando comércio: o tráfico de africanos no vale do Paraíba (1830- } \\
\text { 1860). Dissertação de Mestrado. São Paulo: Faculdade de Filosofia, Letras e Ciências Humanas/USP. } 191 \\
\text { págs. } 2006 .\end{array}$ \\
\hline
\end{tabular}




\begin{tabular}{|c|c|c|}
\hline Local de desembarque & Município & Fonte \\
\hline & São Sebastião - SP & $\begin{array}{c}\text { RODRIGUES, Jaime. O infame comércio - propostas e experiências no final do tráfico de africanos para o } \\
\text { Brasil (1800 a 1850). }\end{array}$ \\
\hline \multirow{3}{*}{ Praia de Toque Toque Grande } & São Sebastião - SP & $\begin{array}{c}\text { BOCCIA, Ana Maria Mathias e MALERBI, Eneida Maria. (1977). O contrabando de escravos para São Paulo. } \\
\text { Revista de História - Ano XXVIII. Vol. LVI. N. 112. Outubro-Dezembro. }\end{array}$ \\
\hline & São Sebastião - SP & José Vieira (Zé Pedro) \\
\hline & São Sebastião - SP & $\begin{array}{c}\text { ALONSO, Priscila de Lima. O vale do nefando comércio: o tráfico de africanos no vale do Paraíba (1830- } \\
\text { 1860). Dissertação de Mestrado. São Paulo: Faculdade de Filosofia, Letras e Ciências Humanas/USP. } 191 \\
\text { págs. } 2006 .\end{array}$ \\
\hline Praia da Barra do Una & São Sebastião - SP & $\begin{array}{l}\text { ALONSO, Priscila de Lima. O vale do nefando comércio: o tráfico de africanos no vale do Paraíba (1830- } \\
\text { 1860). Dissertação de Mestrado. São Paulo: Faculdade de Filosofia, Letras e Ciências Humanas/USP. } 191 \\
\text { págs. } 2006 .\end{array}$ \\
\hline Rio Una até São Sebastião & São Sebastião - SP & $\begin{array}{l}\text { BOCCIA, Ana Maria Mathias e MALERBI, Eneida Maria. (1977). O contrabando de escravos para São Paulo. } \\
\text { Revista de História - Ano XXVIII. Vol. LVI. N. 1․ Outubro-Dezembro. }\end{array}$ \\
\hline Não indicado & Ilhabela - SP & $\begin{array}{l}\text { AGOSTINI, Camilla. Mundo Atlântico e Clandestinidade - Dinâmica material e simbólica em uma fazenda } \\
\text { litorânea no sudeste, século XIX. Tese de doutorado. Universidade Federal Fluminense - UFF. Instituto de } \\
\text { Ciências Humanas e Filosofia Programa de Pós-Graduação em História. Niterói - RJ. } 195 \text { págs. } 2011 .\end{array}$ \\
\hline Praia dos Castelhanos & Ilhabela - SP & $\begin{array}{l}\text { Fernando de Souza Rangel } \\
\end{array}$ \\
\hline Praia dos Castelhanos & Illhabela - SP & $\begin{array}{c}\text { NOFFS, Paulo. A disputa da hegemonia do espaço na Baía de Castelhanos. Tese de doutorado. São Paulo: } \\
\text { Faculdade de Filosofia, Letras e Ciências Humanas/USP. } 261 \text { págs. } 2007\end{array}$ \\
\hline \multirow{3}{*}{ Saco do Sombrio } & Ilhabela - SP & $\begin{array}{c}\text { FRANÇA, Ary. A llha de São Sebastião - estudo de Geografia Humana. Universidade de São Paulo. } \\
\text { Faculdade de Filosofia, Ciências e Letras. Boletim 178, Geografia no 10. } 1954 .\end{array}$ \\
\hline & Ilhabela - SP & $\begin{array}{c}\text { RODRIGUES, Jaime. O infame comércio - propostas e experiências no final do tráfico de africanos para o } \\
\text { Brasil }(1800 \text { a 1850). }\end{array}$ \\
\hline & Ilhabela - SP & Fernando de Souza Rangel \\
\hline
\end{tabular}

